\title{
The volcano-tectonic evolution of the Macquarie Ridge Complex, Australia-Pacific plate boundary south of New Zealand
}

Christopher Edward Conway

A thesis submitted in partial fulfilment of the requirements for the degree of Masters of Science with Honours in Geology

School of Geography, Environment and Earth Sciences

Victoria University of Wellington 


\section{FRONTISPIECE}

'Either you decide to stay in the shallow end of the pool or you go out in the ocean'

-Christopher Reeve

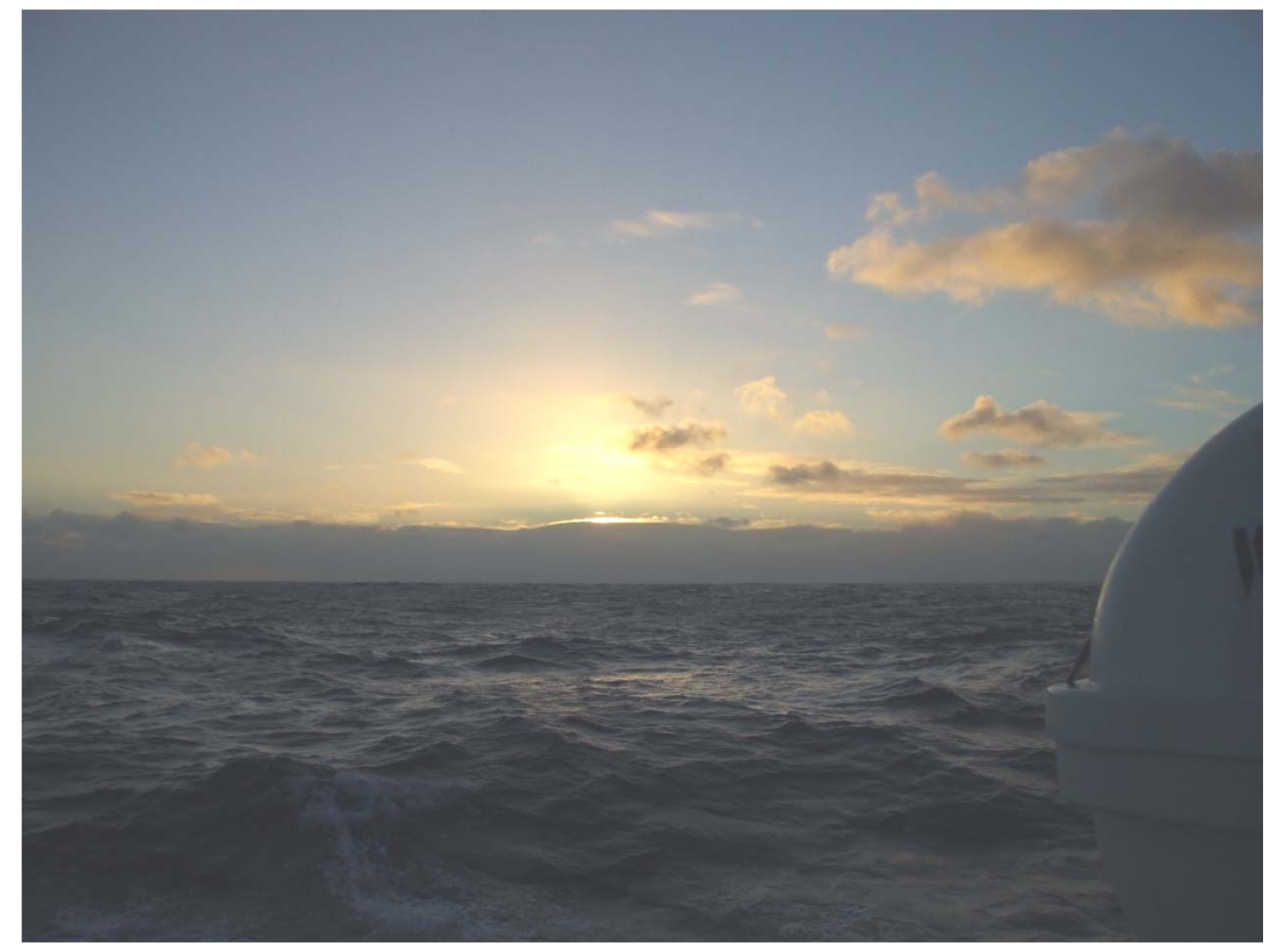

Plate 1. The sun rises over the Southern Ocean. 


\section{ABSTRACT}

The Macquarie Ridge Complex (MRC) forms the submarine expression of the Australia-Pacific plate boundary south of New Zealand, comprising a rugged bathymetry made up of numerous seamounts along its length. Tectonic plate reconstructions show that the plate boundary evolved from divergent to transpressional relative plate motion from ca. $40-6 \mathrm{Ma}$. However, only limited geological observation of the products of past seafloor spreading and present transpressional deformation has been achieved. This study presents new highresolution multibeam, photographic, petrologic and geochemical data for 10 seamounts located along the MRC in order to elucidate the current nature and evolution of the plate boundary.

Seamounts are oriented parallel to the plate boundary, characterized by elongate forms, and deformed by transform faulting. Three guyot-type seamounts display summit plateaux that were formed by wave and current erosion. MRC seafloor is composed of alkaline to sub-alkaline basaltic pillow, massive and sheet lava flows, lava talus, volcaniclastic breccia, diabase and gabbro. This oceanic crust was formed during effusive mid-ocean ridge volcanism at the relic Macquarie spreading centre and has since been sheared, accreted and exhumed along the modern transpressional plate boundary. Major element systematics indicate samples originated from spatially distinct magmatic sources and have since been juxtaposed at seamounts due to transpressional relative plate motion. MRC seamounts have formed as discrete elevations as a result of dip-slip and strike-slip faulting of the ridge axis. Thus, MRC seamounts are volcanic in origin but are now the morphological manifestations of tectonic and geomorphic processes.

Petrologic and geochemical characteristics of volcanic glass samples from the MRC indicate that both effusive and explosive eruption styles operated at the relic Macquarie spreading centre. Primitive and sub-alkaline to transitional basaltic magma that rose efficiently to the seafloor was erupted effusively and cooled to 
form lava flows with low vesicle and phenocryst contents or was granulated on contact with seawater to form hyaloclasts deposited in volcaniclastic breccias. More alkaline magmas that underwent crystal fractionation and volatile exsolution in shallow reservoirs were fragmented and erupted during submarine hawaiian-type eruptions. Such a scenario is likely to have occurred during the final stages of magmatism at the Australia-Pacific plate boundary south of New Zealand when seafloor spreading was ultraslow or had ceased, which induced low degrees of partial melting and retarded magma ascent rates.

All MRC samples display enriched mid-ocean ridge basalt (E-MORB) trace element characteristics. The sample suite can be divided into two groups, with Group 1 samples distinguished from Group 2 samples by their lower concentrations of highly incompatible trace elements, flatter LREE slopes, higher MgO contents and lower alkali element contents. Group 1 basalts were derived from low degree partial melting of spinel Iherzolite generated during the late stages of mid-ocean ridge volcanism at the plate boundary when seafloor spreading rates were slow to ultraslow (full spreading rate $<20 \mathrm{~mm} \mathrm{yr}^{-1}$ ). Group 2 basalts were derived from low degree partial melting of spinel Iherzolite, mixed with small amounts of very low degree partial melting of garnet lherzolite, during post-spreading volcanism at the MRC. Remnant heat from previous seafloor spreading induced buoyant ascent of the sub-ridge mantle and enriched heterogeneities were preferentially tapped by the ensuing low melt fractions. Magma ascent was stalled due to the cessation of extension at the ridge and the melts underwent crystal fractionation prior to eruption, which accounts for the lower $\mathrm{MgO}$ contents of Group 2 basalts. The pervasive incompatible element-enrichment of MRC basalts and similarity to lavas from fossil spreading ridges in the eastern Pacific Ocean may reflect regional enrichment of the Pacific upper mantle. 


\section{ACKNOWLEDGEMENTS}

Joel Baker, Helen Bostock and Richard Wysoczanski are greatly thanked for their support and supervision. I am grateful for having been encouraged to pursue ideas and areas of interest to me throughout the course of this study. Helen Bostock is thanked especially for her overall organisation of the project. Thank you to the crew and scientific staff onboard the RV Tangaroa during voyage TAN0803. I am grateful to Anne-Laure Verdier for guiding me through the intricacies of SonarScope and ArcGIS, and to the rest of the NIWA marine geology team for their assistance. Rob Stewart and Alan Hart are thanked for providing access to the DTIS data. MarcAlban Millet is thanked for his untiring assistance in the lab and general support and guidance. Thank you to John Creech for assistance with EPMA analyses, and to Simon Barker, Aidan Allan, George Cooper, Stewart Bush and Stephen Brown for help with sample preparation. Ben Gillam is greatly thanked for his help with all matters relating to the use of Adobe Illustrator, and Megan Korchinski for all matters relating to my presence in the ultra-clean lab. Thanks to all the office-mates and fellow students who drove me mad and kept me sane over the past two years, especially Ramona, Ben, Megan, Alexa, John, Rachel, Simon, Aidan, George, Holly, Katy, Kim, Kylie, Katie, Gemma, Lucy, Dene, Matt, Boots, the 2011 summer interns and others. I am indebted to Flynn Salter for his unconditional moral and financial support, and to Shane, Tim, Rat, Chom, Paul, Lenny, Crumpy, Romesh, Julian Casablancas and others for their ability to distract me from all worldly troubles. Much love to my sister Juliet and brothers Tom and Nick for their support and encouragement. I would not be where I am today without the love of my parents, my Omi and Opa, and the extended Conway, Paulay, Salter and Sziranyi families. Thank you, for everything, Mum and Dad. 


\section{TABLE OF CONTENTS}

TITLE PAGE

FRONTISPIECE

II

ABSTRACT

III

ACKNOWLEDGEMENTS

V

TABLE OF CONTENTS

VI

LIST OF FIGURES

XI

LIST OF TABLES

XIV

LIST OF PLATES

$X \mathrm{VI}$

CHAPTER 1: Introduction

1

CHAPTER 2: Methods

CHAPTER 3: Submarine geology and geochemistry of the

Macquarie Ridge Complex

29

CHAPTER 4: Petrology and geochemistry of volcanic glass from the

64

Macquarie Ridge Complex

CHAPTER 5: Petrogenesis of enriched mid-ocean ridge basalts from the Macquarie Ridge Complex.

CHAPTER 6: Synthesis

REFERENCES

APPENDIX 1: Multibeam mapping techniques 


\section{CHAPTER 1: INTRODUCTION}

\begin{tabular}{ll}
1.1 & INTRODUCTION \\
\hline
\end{tabular}

1.1.1 Objectives of this study 2

1.1.2 Thesis structure 3

1.2 OCEANIC PLATE BOUNDARIES AND SEAMOUNTS 4

1.2.1 Divergent plate boundaries $\quad 4$

1.2.2 Transpressional plate boundaries $\quad 4$

$\begin{array}{ll}1.2 .3 \text { Seamounts } & 5\end{array}$

1.3 REGIONAL OVERVIEW OF THE MACQUARIE RIDGE COMPLEX 5

$\begin{array}{ll}\text { 1.3.1 Australia-Pacific plate boundary evolution } & 7\end{array}$

1.3.2 Morphology and geochemistry of the Macquarie Ridge Complex 8

$\begin{array}{ll}\text { 1.3.3 Macquarie Island } & 8\end{array}$

1.3.4 Southern Ocean volcanism $\quad 9$

1.3.4.1 Solander Island $\quad 9$

$\begin{array}{ll}\text { 1.3.4.2 Hjort Plateau seamounts } & 10\end{array}$

$\begin{array}{ll}\text { 1.3.4.3 Balleny Island } & 10\end{array}$

CHAPTER 2: METHODS

$\begin{array}{ll}\text { 2.1 MULTIBEAM MAPPING } & 12\end{array}$

2.1.1 Multibeam data acquisition $\quad 12$

2.1.2 Processing of backscatter data $\quad 12$

2.1.3 Qualitative analysis of multibeam data 12

$\begin{array}{ll}2.2 \text { UNDERWATER IMAGERY } & 13\end{array}$

2.2.1 Deep-Towed Imaging System 13 
$\begin{array}{ll}\text { 2.2.3 Substrate classification } & 14\end{array}$

$\begin{array}{ll}\text { 2.3 GEOCHEMICAL ANALYTICAL TECHNIQUES } & 15\end{array}$

2.3.1 Sample acquisition and preparation $\quad 15$

$\begin{array}{ll}\text { 2.3.1.1 Epibenthic sled dredging } & 15\end{array}$

2.3.1.2 Volcanic glass sample preparation $\quad 15$

$\begin{array}{ll}\text { 2.3.1.3 Whole rock sample preparation } & 17\end{array}$

$\begin{array}{ll}\text { 2.3.2 Volcanic glass major element analysis } & 18\end{array}$

$\begin{array}{ll}\text { 2.3.2.1 Electron probe microanalysis } & 18\end{array}$

$\begin{array}{ll}\text { 2.3.2.2 Precision and accuracy } & 19\end{array}$

$\begin{array}{ll}\text { 2.3.3 Whole rock major element analysis } & 19\end{array}$

2.3.3.1 X-ray fluorescence spectrometry 19

$\begin{array}{ll}\text { 2.3.3.2 Accuracy } & 20\end{array}$

2.3.4 Volcanic glass and whole rock trace element analysis 20

$\begin{array}{ll}\text { 2.3.4.1 Laboratory protocol } & 20\end{array}$

$\begin{array}{ll}\text { 2.3.4.2 Sample digestion } & 20\end{array}$

$\begin{array}{ll}\text { 2.3.4.3 Sample dilution } & 21\end{array}$

$\begin{array}{ll}\text { 2.3.4.4 Mass spectrometry } & 22\end{array}$

2.3.4.5 Data reduction and concentration calculation 22

$\begin{array}{ll}\text { 2.3.4.6 Precision and accuracy } & 24\end{array}$

CHAPTER 3: SUBMARINE GEOLOGY AND GEOCHEMISTRY OF THE MACQUARIE RIDGE COMPLEX

$\begin{array}{ll}3.1 \text { INTRODUCTION } & 31\end{array}$

3.2. GEOLOGICAL SETTING OF THE MACQUARIE RIDGE COMPLEX 31

3.3. METHODS 34

3.3.1 Multibeam mapping $\quad 34$

3.3.2 Underwater towed-camera images $\quad 35$

3.3.3 Petrology and geochemistry analytical techniques 35 
3.3.3.2 Major element analysis $\quad 36$

$\begin{array}{ll}3.4 \text { RESULTS } & 36\end{array}$

3.4.1 Seamount morphology 36

3.4.2 Substrate composition $\quad 50$

3.4.3 Major element chemistry 52

3.5. DISCUSSION

3.5.1 Volcanism at the relic Macquarie spreading centre 54

3.5.2 Formation of MRC seamounts 57

3.6 CONCLUSIONS 63

CHAPTER 4: PETROLOGY AND GEOCHEMISTRY OF VOLCANIC GLASS FROM THE MACQUARIE RIDGE COMPLEX

$\begin{array}{ll}4.1 \text { INTRODUCTION } & 65\end{array}$

4.2 GEOLOGICAL SETTING OF THE MACQUARIE RIDGE COMPLEX 67

4.3 SAMPLES AND METHODS 69

$\begin{array}{ll}\text { 4.4 RESULTS } & 70\end{array}$

$\begin{array}{ll}\text { 4.4.1 Petrology } & 71\end{array}$

$\begin{array}{ll}\text { 4.4.2 Geochemistry } & 74\end{array}$

$\begin{array}{ll}4.5 \text { DISCUSSION } & 76\end{array}$

$\begin{array}{ll}\text { 4.6 CONCLUSIONS } & 79\end{array}$

CHAPTER 5: PETROGENESIS OF ENRICHED MID-OCEAN RIDGE BASALTS FROM THE MACQUARIE RIDGE COMPLEX

$\begin{array}{ll}5.1 \text { INTRODUCTION } & 82\end{array}$

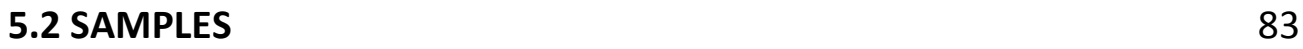

$\begin{array}{ll}\text { 5.3 METHODS } & 83\end{array}$

$\begin{array}{lll}5.4 \text { RESULTS } & 84\end{array}$

5.4.1 Major element chemistry 84 
$\begin{array}{ll}\text { 5.4.1.1 Chemical classification } & 84\end{array}$

5.4.1.2 Bivariate MgO-major element diagrams 91

$\begin{array}{ll}\text { 5.4.2 Trace element chemistry } & 91\end{array}$

$\begin{array}{ll}\text { 5.4.2.1 Trace element concentrations } & 91\end{array}$

5.4.2.2 Bivariate MgO-trace element diagrams 93

5.4.2.3 Multielement and REE diagrams 93

$\begin{array}{ll}\text { 5.5 DISCUSSION } & 93\end{array}$

5.5.1 Magmatic processes at the relic Macquarie spreading centre 93

5.5.2 Mantle processes at the relic Macquarie spreading centre 98

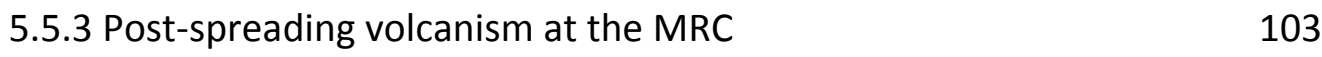

5.5.4 Mantle heterogeneity beneath the relic Macquarie $\begin{array}{ll}\text { spreading centre } & 106\end{array}$

$\begin{array}{ll}5.6 \text { CONCLUSIONS } & 108\end{array}$

CHAPTER 6: SYNTHESIS

$\begin{array}{ll}\text { 6.1 SUMMARY MODEL } & 111\end{array}$

$\begin{array}{ll}\text { 6.2 SUGGESTIONS FOR FUTURE WORK } & 113\end{array}$

REFERENCES

$\begin{array}{ll}\text { References } & 117\end{array}$

APPENDICE 1: MULTIBEAM MAPPING TECHNIQUES

$\begin{array}{ll}\text { A1.1 Bathymetry resolution } & 133\end{array}$

$\begin{array}{ll}\text { A1.2 Backscatter data processing steps } & 134\end{array}$

APPENDIX 2: SUBSTRATE CLASSIFICATION GUIDE

$\begin{array}{ll}\text { A2.1 DTIS specifications } & 138\end{array}$

$\begin{array}{ll}\text { A2.2 Substrate classification guide } & 138\end{array}$ 


\section{APPENDIX 3: PETROGRAPHIC DESCRIPTIONS}

\section{LIST OF FIGURES}

\section{CHAPTER 1: INTRODUCTION}

1.1 Regional and tectonic setting of the Macquarie Ridge Complex and location of seamounts investigated for this study

\section{CHAPTER 3: SUBMARINE GEOLOGY AND GEOCHEMISTRY OF MACQUARIE RIDGE COMPLEX SEAMOUNTS}

3.1 Regional and tectonic setting of the Macquarie Ridge Complex and location of seamounts investigated in this study

3.2 Bathymetry and backscatter maps of Macquarie Ridge Complex seamounts

3.3 Images from DTIS investigation of Macquarie Ridge Complex seamount substrates

3.4 Representative microphotographs (plane-polarised light) for Macquarie Ridge Complex dredge samples

3.5 Total alkalis-silica classification diagram for Macquarie Ridge Complex samples

3.6 Major element content and $\mathrm{K} / \mathrm{Ti}$ ratio versus latitude for Macquarie Ridge Complex samples

3.7 Bivariate $\mathrm{MgO}-$ major element diagrams for samples from the Macquarie Ridge Complex 
3.8 Schematic model for the evolution of the Macquarie Ridge

Complex

\section{CHAPTER 4: PETROLOGY AND GEOCHEMISTRY OF VOLCANIC GLASS FROM THE MACQUARIE RIDGE COMPLEX}

4.1 Regional and tectonic setting of the Macquarie Ridge Complex

and location of new volcanic glass samples

68

4.2 Representative back-scattered electron images for volcanic

glass samples from the Macquarie Ridge Complex

4.3 Total alkalis-silica classification diagram for volcanic glass

samples from the Macquarie Ridge Complex

4.4 Bivariate $\mathrm{MgO}$-major element diagrams for volcanic glass

samples from the Macquarie Ridge Complex

4.5 Eruption models for volcaniclastic rocks formed at the relic

Macquarie spreading centre

\section{CHAPTER 5: PETROGENESIS OF ENRICHED MID-OCEAN RIDGE BASALTS FROM THE MACQUARIE RIDGE COMPLEX}

5.1 Total alkalis-silica classification diagram for samples from the Macquarie Ridge Complex

5.2 Bivariate $\mathrm{MgO}$-major element diagrams for samples from the Macquarie Ridge Complex

5.3 Bivariate MgO-trace element diagrams for samples from the Macquarie Ridge Complex

5.4 Multielement diagrams for samples from the Macquarie Ridge Complex

5.5 REE diagrams for samples from the Macquarie Ridge Complex

5.6 Multielement and REE diagrams for samples from the 
5.7 Bivariate Th-trace element diagrams for samples from the

Macquarie Ridge Complex

5.8 Plot of $\mathrm{Nb} / \mathrm{Zr}$ versus $\mathrm{Nb}$ content for new samples from the

Macquarie Ridge Complex

100

5.9 Trace element ratio diagrams of $\mathrm{Ce} / \mathrm{Y}$ versus $\mathrm{Zr} / \mathrm{Nb}$ and

Gd/Dy versus La/Sm for modelled partial melts and Macquarie

Ridge Complex samples

102

5.10 REE diagram of samples from fossil spreading ridges and the

Macquarie Ridge Complex

105

\section{CHAPTER 6: SYNTHESIS}

6.1 Summary model for the evolution of the Macquarie Ridge

Complex

\section{APPENDIX 1: MULTIBEAM MAPPING TECHNIQUES}

A1.1Multibeam resolution in the longitudinal $(\delta x)$ and transverse $(\delta y)$ directions

A1.2 Example of a compensation curve applied to original

backscatter data to correct for the specular signal

\section{APPENDIX 2: SUBSTRATE CLASSIFICATION GUIDE}

A2.1 Pillow lava flows from the Macquarie Ridge Complex

A2.2 Massive lava flows from the Macquarie Ridge Complex

A2.3 Sheet lava flows from the Macquarie Ridge Complex

A2.4 Volcaniclastic breccias from the Macquarie Ridge Complex

A2.5 Lava talus and clastic material from the Macquarie Ridge 


\section{APPENDIX 3: PETROGRAPHIC DESCRIPTIONS}

A3.1 Photographs and microphotographs of whole rock dredge samples from the Macquarie Ridge Complex

\section{LIST OF TABLES}

\section{CHAPTER 2: METHODS}

2.1 DTIS transect co-ordinates

2.2 Location, type and methods of analysis for dredge samples from the Macquarie Ridge Complex

2.3 Precision and accuracy for EPMA analyses of international glass standards KL2-G and VG-A99

2.4 Accuracy of XRF analyses for international rock standards BCR-2 and BHVO-2

2.5 ICP-MS instrumental and analytical conditions

2.6 Accuracy and precision of solution ICP-MS analyses for international rock standard BCR-2

2.7 Accuracy and precision of solution ICP-MS analyses for international rock standard BHVO-2

2.8 Accuracy of solution ICP-MS analyses for duplicate sample digestions

\section{CHAPTER 3: SUBMARINE GEOLOGY AND GEOCHEMISTRY OF MACQUARIE RIDGE COMPLEX SEAMOUNTS}

3.1 Summary of Macquarie Ridge Complex seamount 
3.2 Average EPMA and XRF analyses for Macquarie Ridge Complex dredge samples

\section{CHAPTER 4: PETROLOGY AND GEOCHEMISTRY OF VOLCANIC GLASS FROM THE MACQUARIE RIDGE COMPLEX}

4.1 Summary of information for Macquarie Ridge Complex

volcanic glass samples

4.2 Petrology of Macquarie Ridge Complex volcaniclastic

breccia samples

4.3 Average EPMA analyses of Macquarie Ridge Complex

volcanic glass samples

\section{CHAPTER 5: PETROGENESIS OF ENRICHED MID-OCEAN RIDGE BASALTS FROM THE MACQUARIE RIDGE COMPLEX}

5.1 Major and trace element composition of Macquarie Ridge Complex samples 85

\section{APPENDIX 2: SUBSTRATE CLASSIFICATION GUIDE}

A2.1 DTIS technical specifications

\section{APPENDIX 3: PETROGRAPHIC DESCRIPTIONS}

A3.1 Summary of petrographic types for Macquarie Ridge Complex dredge samples 


\section{LIST OF PLATES}

Plate 1. The sun rises over the Southern Ocean II

Plate 2. A solitary fish surveys the substrate of seamount 4

Plate 3. Backscattered electron image of a glass shard from

volcaniclastic breccia sample $98 \mathrm{~A}$

Plate 4. An octopus spreads out on the substrate of seamount 6

Plate 5. Starfish and tube worms cling to a glassy lava flow on seamount 6

Plate 6. Pillow lavas on the Macquarie Ridge Complex seafloor

Plate 7. The sun sets over the Southern Ocean

Plate 8. Waves roll out across the Southern Ocean

Plate 9. A close-up photograph of the seafloor captures a

miniature garden of corals on seamount 9

Plate 10. Photograph of a hyaloclastite breccia sample recovered from the Macquarie Ridge Complex seafloor 


\section{CHAPTER 1:}

\section{INTRODUCTION}

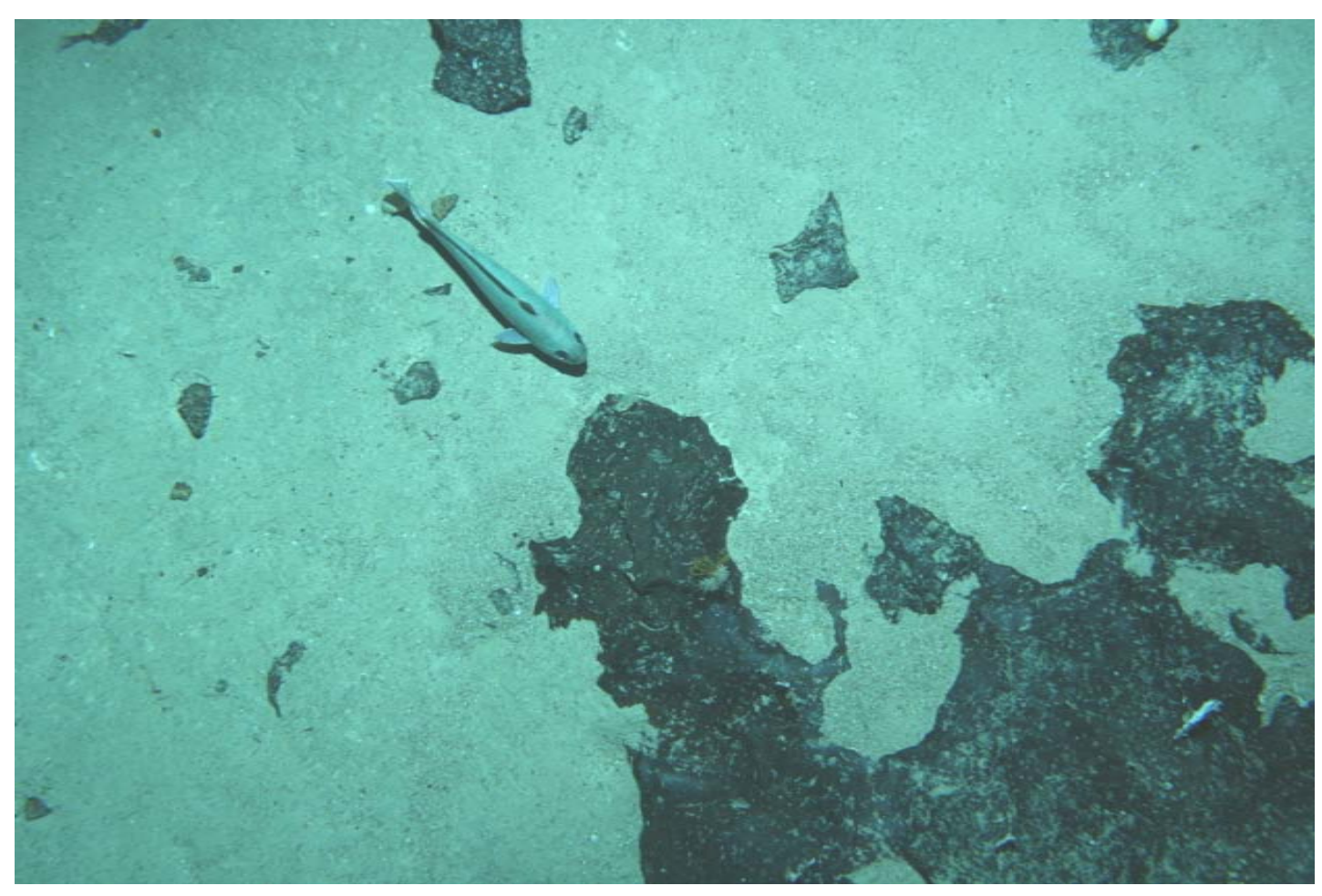

Plate 2. A solitary fish surveys the substrate of seamount 4. 


\subsection{INTRODUCTION}

Oceanic plate boundaries are regions on Earth's surface where crust is created, deformed or destroyed, depending on the relative motion of the adjacent plates. The Macquarie Ridge Complex (MRC) represents the submarine expression of the Australia-Pacific plate boundary south of New Zealand, which has undergone an extensive and rapid evolution, encompassing divergent, transform and convergent relative plate motion from $40 \mathrm{Ma}$ to the present day. This evolution has been documented through plate tectonic reconstructions, yet geological evidence for past seafloor spreading and current transpressional relative plate motion remains scarce for this remote region of the southwest Pacific Ocean. As such, an opportunity is presented to investigate scales of mantle heterogeneity, mechanisms of submarine volcanic eruption and types of crustal deformation along a ca. 1,600 $\mathrm{km}$-long plate boundary.

\subsubsection{Objectives of this study}

The aim of this study was to answer three main questions:

1. What geological processes control the morphology of the MRC and what is the origin and evolution of MRC seamounts?

2. How was lava erupted at the relic Macquarie spreading centre and what are the implications for volcanism at slow-spreading mid-ocean ridges?

3. What are the mantle sources and processes that gave rise to mid-ocean ridge volcanism at the relic Macquarie spreading centre?

In order to answer these questions, this thesis presents results from high-resolution multibeam bathymetry and backscatter mapping, photographic investigation, and the most comprehensive submarine sample dredge operation to date of the MRC seafloor. The outcome is a detailed dataset which provides the geological and geochemical evidence required to define the current nature of the MRC and the evolution of the Australia-Pacific plate boundary south of New Zealand. As the plate 
boundary has encompassed all three end-member relative plate motions during the last $40 \mathrm{Myr}$, elucidating the different stages of its evolution is relevant to studies of divergent, transform and convergent plate boundaries.

\subsubsection{Thesis structure}

This dissertation is structured as follows:

Chapter 1. Introduction: A brief review of oceanic plate boundaries and an overview of the regional geology of the Macquarie Ridge Complex.

Chapter 2. Methods: A description of the acquisition of multibeam, photographic, petrologic and geochemical data used in this study and the methods employed to analyse the data.

Chapter 3. Geology and geochemistry of Macquarie Ridge Complex seamounts: The morphology, structure and composition of MRC seamounts are defined through multibeam mapping and remote observation of the seafloor and a petrological and geochemical examination of rock samples. This chapter was prepared as a manuscript for journal publication and has been submitted to Marine Geology.

Chapter 4. Petrology and geochemistry of volcanic glass from the Macquarie Ridge Complex : A petrological and geochemical investigation of glassy pillow lava and volcaniclastic breccia samples is presented in order to reveal the physical and chemical controls on the style of volcanic eruption at the relic Macquarie spreading centre. This chapter was prepared as a manuscript for journal publication in Bulletin of Volcanology.

Chapter 5. Petrogenesis of enriched mid-ocean ridge basalts from the Macquarie Ridge Complex: A major and trace element study of igneous rock samples collected from the MRC and analysed by electron probe microanalysis, $\mathrm{X}$-ray fluorescence and inductively coupled plasma mass spectrometry is presented in this chapter.

Chapter 6. Synthesis: The main findings from this study and suggestions for future work are presented in this chapter. 
Appendices: This section contains additional detailed information including: an outline of the procedure used in this study to process multibeam backscatter data; a guide for substrate classification developed during this study; and full petrographic rock sample descriptions.

\subsection{OCEANIC PLATE BOUNDARIES}

\subsubsection{Divergent plate boundaries}

The global mid-ocean ridge system comprises the Mid-Atlantic Ridge, East Pacific Rise, Southeast Indian Ridge, Southwest Indian Ridge, Central Indian Ridge, American-Antarctic Ridge, Pacific-Antarctic Ridge, Juan de Fuca Ridge, Galapagos Ridge and Chile Ridge. Oceanic crust is created these boundaries via upwelling and adiabatic decompression melting of mantle material as plates move apart (Bottinga et al., 1978). This process typically taps the depleted upper mantle, resulting in the eruption of basaltic lava with a relatively uniform composition across the ocean basins (i.e. normal mid-ocean ridge basalt, N-MORB; Hoffman et al., 1986). However, enriched (E-) MORB signatures suggest the presence of chemical heterogeneities in the upper mantle (e.g. Niu et al., 1999). Determining the nature and origin of these heterogeneities remains a crucial step in understanding the chemical and physical dynamics of Earth's mantle.

\subsubsection{Transpressional oceanic plate boundaries}

According to classical plate tectonic theory, transform boundaries are assumed to be regions where plates slide past each other, such that crust is neither created nor destroyed (Wilson, 1965). However, relative plate motion is rarely of a pure transcurrent direction and the result is a more complex transpressional or transtensional regime (Pockalny et al., 1997). As a result, there are morphological consequences of the plate motion, manifest as deformational structures on the seafloor (e.g. Pockalny, 1997; Sonder \& Pockalny, 1999; Galindo-Saldívar et al., 2000). Continental transpressional plate boundaries have received much attention 
due to the relative ease that they can be surveyed (e.g. the Alpine and San Andreas faults). Conversely, oceanic transform plate boundaries are relatively rare and research has been restricted to the well-studied global fracture zone network (e.g. Kastens, 1987).

\subsubsection{Seamounts}

Seamounts are important sites for biological, tectonic and mantle dynamics research as they provide habitats for benthic ecosystems, record past plate motions and sample chemical heterogeneities in the mantle. A seamount is defined in the broadest sense as any geographically isolated feature on the seafloor that is taller than $100 \mathrm{~m}$ and not located on continental shelves (Staudigel et al., 2010). However, the term is more traditionally used to describe active or extinct intraplate volcanoes, this being the original intention (Menard, 1964). The broader definition allows for the inclusion of mid-ocean ridge and subduction volcanoes, as well as other significant bathymetric features (Staudigel et al., 2010). A guyot is a class of seamount characterized by a flat-topped summit. This classification holds with it an evolutionary interpretation because guyot flat-tops are produced by wave erosion; the seamounts are likely to have previously existed as islands (Staudigel \& Clague, 2010).

\subsection{REGIONAL OVERVIEW OF THE MACQUARIE RIDGE COMPLEX}

The Macquarie Ridge Complex (MRC) is a narrow and arcuate submarine ridge extending from $46^{\circ} 30^{\prime} \mathrm{S}$ to $60^{\circ} 00^{\prime} \mathrm{S}$ and coincides with the Australia-Pacific plate boundary south of New Zealand (Fig. 1.1). Despite the general remoteness of the MRC, several cruises to the Southern Ocean have been undertaken throughout the last 45 years. The research efforts have focussed on the morphology of the active transpressional plate boundary (Schuur et al., 1998; Massell et al., 2000; Daczko et al., 2003), the development of subduction initiation (Collot et al., 1995; Meckel et al., 2003), the notable plate boundary seismicity (Ruff et al., 1989; Das, 1993; 


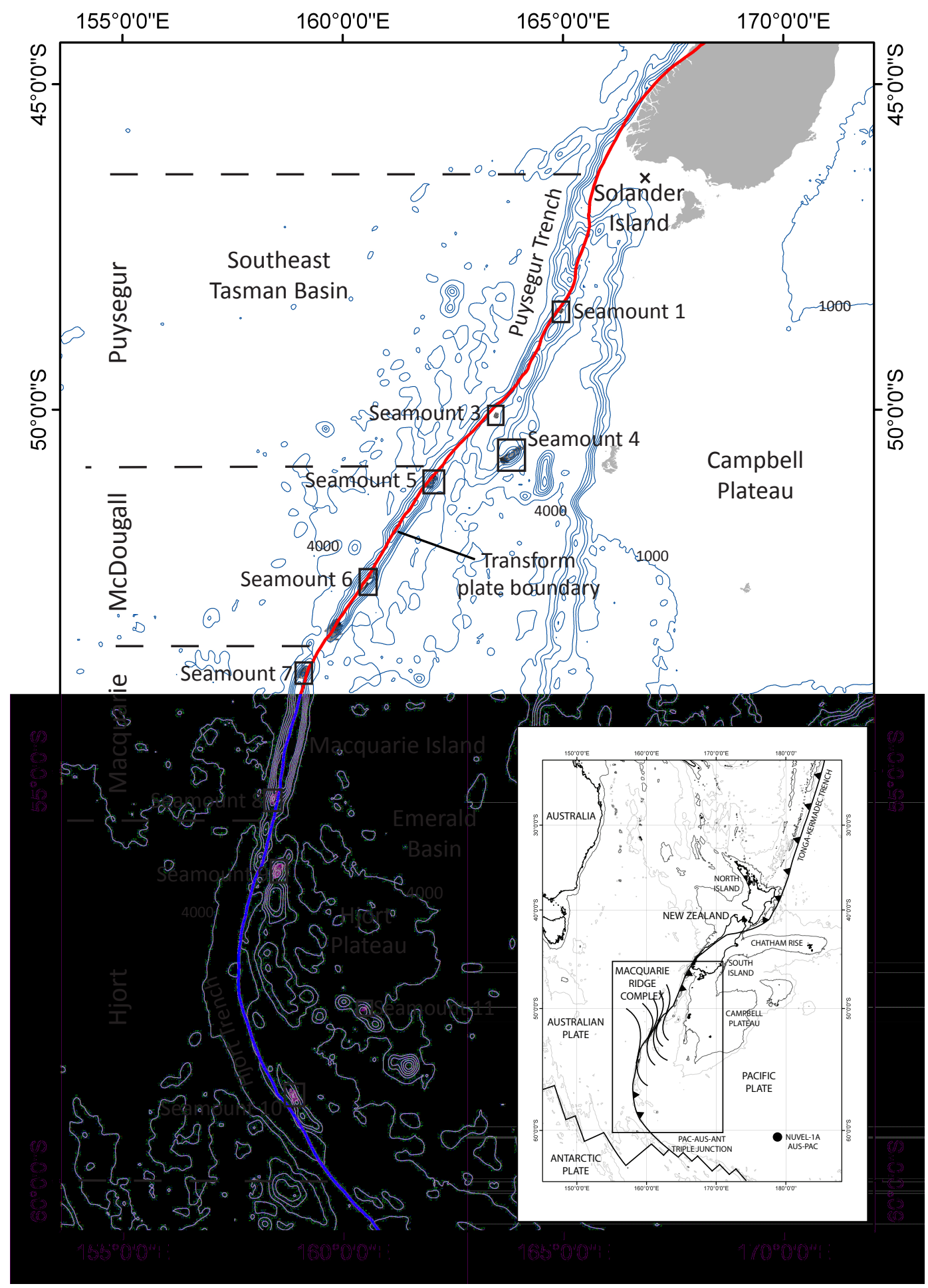

Figure 1.1. Bathymetric map of the Macquarie Ridge Complex and location of the 10 seamounts studied here (inset: position of the MRC relative to New Zealand and Australia). Isobaths shown for 1000, 1500, 2000, 2500, 3000 and 4000 m; 1000 and 4000 m isobaths are noted. The dextral transform plate boundary (red line) trends along the axis of the ridge. Black triangles indicate subduction of the Australian plate at the Puysegur and Hjort trenches (inset). Black circle represents the pole of relative Australia-Pacific plate motion (inset; DeMets et al., 1994). Thin black lines represent fracture zones that trend asymptotically into the plate boundary (inset). 
Frohlich et al., 1997), the age and composition of regional oceanic crust (Mortimer, 1995; Wood et al., 1996) and the stratigraphy and geochemistry of Macquarie Island (Kamenetsky et al., 2000; Wertz et al., 2003; Dijkstra \& Cawood, 2004).

\subsubsection{Australia-Pacific plate boundary evolution}

The MRC was initially thought to form a branch of the global mid-ocean ridge system (Ewing \& Heezen, 1956). Upon more detailed mapping of the ridge (e.g. Brodie \& Dawson, 1965; Summerhayes, 1967), it was subsequently proposed that the ridge belonged to the circum-Pacific island arc system based on its apparent similarity to other such plate boundaries (Cullen, 1967). Hayes and Talwani (1972) concluded that the paired ridge-trough morphology of the MRC is a result of past or ongoing transform and convergent relative plate motion. The variety of conflicting interpretations demanded more detailed structural and morphological research on the region, which spawned a model for the evolution of the MRC.

The plate boundary was a seafloor spreading centre from ca. 40 to $6 \mathrm{Ma}$ (Wood et al., 1996; Mosher \& Massell-Symons, 2008). With the southward migration of the pole of relative plate motion throughout the Cenozoic, relative plate motion became transform (Walcott, 1984; Sutherland, 1995). Current relative plate motion is obliquely convergent (Fig. 1.1; De Mets et al., 1994) and deformation is partitioned into boundary-parallel strike-slip faults and boundary-normal convergent motion (Daczko et al., 2003). Transform motion is accommodated by the Macquarie Fault Zone, which is a $5-10 \mathrm{~km}$-wide zone of strike-slip deformation located along the axis of the MRC (Massell et al., 2000). Seismic activity is dominated by right-lateral slip along the McDougall and Macquarie segments of the plate boundary (Frohlich et al., 1997). Approximately $200 \mathrm{~km}$ of boundary-normal convergence has occurred at the Puysegur and Hjort segments since at least $10 \mathrm{Ma}$ (Meckel et al., 2003), resulting in past and ongoing subduction of the Australian plate beneath the Pacific plate (Fig. 1; Lamarche \& Lebrun, 2000; Meckel et al., 2005). 


\subsubsection{Morphology and geochemistry of the Macquarie Ridge Complex}

The MRC is $1,600 \mathrm{~km}$ long, between 10 and $40 \mathrm{~km}$ wide, comprises a rugged bathymetry and is generally shallower than $1,000 \mathrm{~m}$ water depth along the length of its axis (Schuur et al., 1998; Massell et al., 2000). The MRC changes orientation markedly in three places, delineating the four ridge segments: Puysegur, McDougall, Macquarie and Hjort (Fig. 1.1). Trenches adjacent to the ridge are located to the east of the McDougall and Macquarie ridge segments (Fig. 1.1). Trenches located west of the Puysegur (Puysegur Trench; $46^{\circ} 00^{\prime}$ to $47^{\circ} 30^{\prime} \mathrm{S}$ ) and Hjort (Hjort Trench; $57^{\circ} 30^{\prime}$ to $59^{\circ} 30^{\prime}$ S) segments are recognized as incipient subduction zones (Fig. 1.1; Collot et al., 1995; Meckel et al., 2003).

Crust surrounding the MRC is proposed to be oceanic and have formed at the past Australia-Pacific divergent plate boundary (herein defined as the relic Macquarie spreading centre), as corroborated by magnetic data (Wood et al., 1996) and the identification of tectonic spreading fabric (Massell et al., 2000). However, the Hjort segment has never experienced a spreading history, instead evolving as a transform fault between the relic Macquarie and Southeast Indian spreading ridges, and oceanic crust west of the Hjort Trench originated from the Southeast Indian Ridge (Meckel, 2003). Only limited dredging (Summerhayes, 1969; Schilling \& Ridley, 1975; Matveyenkov \& Baranov, 1981) and drilling (Watkins \& Gunn, 1971) of the MRC and surrounding seafloor has been carried out and the composition and age of the oceanic crust remains poorly known. The most recent synthesis of petrologic and geochemical data for samples recovered from the submarine portion of the ridge concluded that sparse sampling and incomplete chemical analyses generally defined a mafic suite of volcanic rocks with MORB and ocean island basalt (OIB) affinities (Mortimer, 1995).

\subsubsection{Macquarie Island}

Macquarie Island $\left(54^{\circ} 30^{\prime} \mathrm{S}, 158^{\circ} 56^{\prime} \mathrm{E}\right.$ ) is the sole subaerial exposure of the MRC (Fig. 1.1). Furthermore, it is the only ophiolite preserved in an intra-oceanic environment 
(Varne et al., 1969). As such, it has not only been the focus of the petrologic and geochemical studies of MRC oceanic crust, but provides a rare opportunity to examine the well-preserved stratigraphic and chemical architecture of oceanic lithosphere. Varne et al. (1969) identified Macquarie Island as a section of oceanic crust and several petrologic and geochemical studies followed (e.g. Griffin \& Varne, 1980; Duncan \& Varne, 1988). Recent work on the island has included structural studies (Goscombe \& Everard, 2001; Daczko et al., 2003; Wertz et al., 2003; Dijkstra \& Cawood, 2004; Mosher \& Massell-Symons, 2008) and petrologic and geochemical examination of volcanic (Kamenetsky et al., 2000; Kamenetsky \& Maas, 2002; Wertz, 2003; Daczko et al., 2009; Portner et al., 2009) and plutonic (Bazylev \& Kamenetsky, 1998; Dijkstra et al., 2009) rocks. Macquarie Island crust has been dated at between 12 and 8 Ma with ${ }^{40} \mathrm{Ar}-{ }^{39} \mathrm{Ar}$ dating of basaltic samples (Duncan \& Varne, 1988) and biostratigraphic ages from microfossils in sediment between pillow lavas (Quilty et al., 2008). This places the formation of Macquarie Island crust at the end of seafloor spreading for the plate boundary according to tectonic reconstructions (Mosher \& Massell-Symons., 2008). The dominantly E-MORB chemistry of the volcanic rocks is suggested to be the result of low degrees of partial melting during the waning stages of magmatism when seafloor spreading rates were slow (Wertz, 2003). Transpressional relative plate motion subsequent to the cessation of spreading is responsible for the emergence of the island above sealevel (Daczko et al., 2003).

\subsubsection{Southern Ocean volcanism}

\subsubsection{Solander Island}

Solander Island is the subaerial exposure of an extinct andesitic volcano located east of the Puysegur Trench in Foveaux Strait (Fig. 1.1; Reay, 1986). It is the only known volcano related to subduction along the Australia-Pacific plate boundary south of New Zealand. The biotite-hornblende andesite lavas were re-interpreted as adakites by Reay and Parkinson (1997). Recent biotite ${ }^{40} \mathrm{Ar}-{ }^{39} \mathrm{Ar}$ ages from Solander lavas date volcanism at between 400 and $150 \mathrm{ka}$ (Mortimer, 2008). 


\subsubsection{Hjort Plateau seamounts}

The Hjort Plateau is a submarine plateau located east of the Hjort Ridge between latitudes $56^{\circ} 00^{\prime} \mathrm{S}$ and $60^{\circ} 00^{\prime} \mathrm{S}$ (Meckel et al., 2003; Fig. 1.1). The plateau varies in depth from 1,000 to $3,500 \mathrm{~m}$ below sea-level due to the presence of numerous scarps, lineaments and volcanic edifices (Meckel et al., 2003). To date, no rock samples have been recovered from the volcanic edifices and their age and petrogenetic origin remain unknown.

\subsubsection{Balleny Islands}

The Balleny Islands $\left(70^{\circ} 00^{\prime} \mathrm{S}, 163^{\circ} 00^{\prime} \mathrm{E}\right)$ formed as a result of intraplate volcanism associated with the Balleny plume from $10 \mathrm{Ma}$ to the present in the Ross Sea region of Antarctica (Wright \& Kyle, 1990). The Balleny province is defined by an alkalic OIB suite of volcanic rocks (Lanyon et al., 1993). 


\section{CHAPTER 2:}

\section{METHODS}

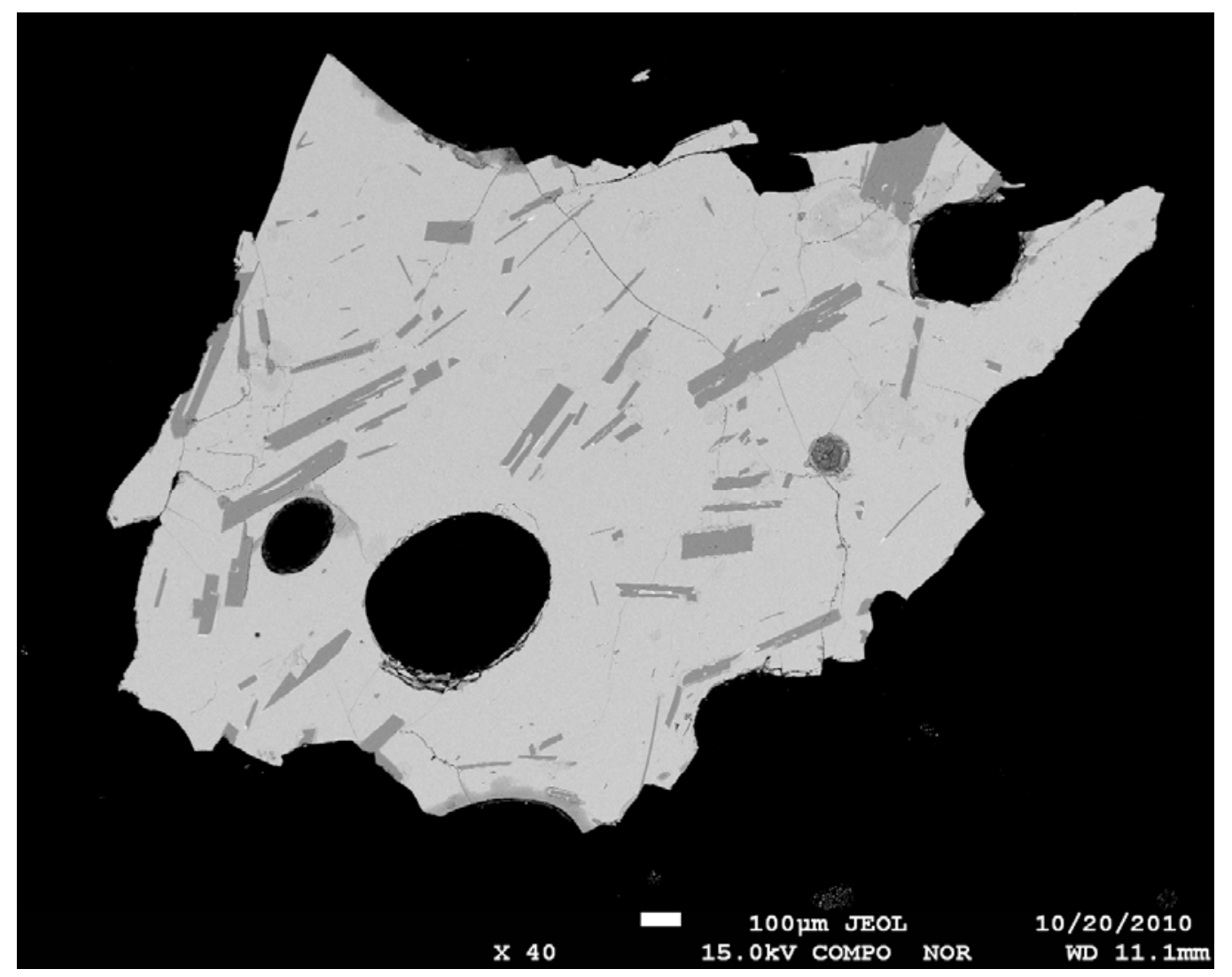

Plate 3. Backscattered electron image of a glass shard from volcaniclastic breccia sample 98A. 


\subsection{MULTIBEAM MAPPING}

\subsubsection{Multibeam data acquisition}

A research survey of the Macquarie Ridge Complex (MRC) was undertaken by the National Institute of Water and Atmospheric Research (NIWA) on the RV Tangaroa during the TAN0803 voyage of March-April 2008. The survey included a comprehensive submarine mapping exercise which focussed on ten discrete seamount features that are elevated from the surrounding ridge axis or seafloor. In this study, the seamounts are numbered $1-11$; investigation of seamount 2 was abandoned due to time constraints. Bathymetric and backscatter data were acquired simultaneously by the vessel's Kongsberg EM300 multibeam echosounder.

\subsubsection{Processing of backscatter data}

Bathymetry data from the TAN0803 voyage were processed initially on the RV Tangaroa using HYDROMAP ${ }^{\mathrm{TM}}$ software. This allowed the assembly of preliminary maps while at sea to aid navigation during towed-camera deployment and dredge sampling. For this project, the backscatter data were processed using SonarScope, a software program designed by l'Institut français de recherche pour l'éxploitation de la mer (IFREMER) for multibeam data manipulation and analysis. While the bathymetry data were reprocessed in SonarScope as a necessary component of the backscatter processing, the original HYDROMAP ${ }^{\mathrm{TM}}$ bathymetry maps were used for qualitative analysis. The method of data processing followed that outlined by Lamarche et al. (2011). An overview of the procedure carried out for this study is provided in Appendix 1.

\subsubsection{Qualitative analysis of backscatter data}

Multibeam maps were imported into ArcGIS (ArcSoft version 9.1) in order to aid presentation and interpretation of the data. Bathymetry maps allowed description and characterization of seamount location, shape, orientation, depth, summit 
extent and slope angle of flanks. Geological features were recognized based on comparison of bathymetry and backscatter maps. Faults were located based on distinct breaks in slope and linear regions of high reflectivity where crust is exposed (i.e. fault scarps). Deposits resulting from mass wasting were recognized based on hummocky or bumpy topography and zones of anomalous reflectivity. Bathymetry and backscatter maps were also imported into the program Fledermaus iView4D to gain a three-dimensional view of the seamounts. This was particularly useful for recognizing changes in reflectivity strength associated with small-scale bathymetric features and seabed composition.

\subsection{UNDERWATER IMAGERY}

\subsubsection{Deep-Towed Imaging System}

The first-ever remote observation of the MRC seafloor was achieved by deployment of NIWA's Deep-Towed Imaging System (DTIS) during voyage TAN0803. The DTIS consists of a high-resolution video camera and a digital single lens reflex still camera, both mounted on a steel frame, which was lowered to the seafloor by a single core steel-armoured cable from the RV Tangaroa. A more complete list of DTIS technical specifications is provided in Appendix 2.

\subsubsection{DTIS deployment}

Deployment of the DTIS on cruise TAN0803 was conducted in order to characterize the substrate composition of MRC seamounts. The aim was to undertake at least two photographic transects on each seamount, extending from the peak and traversing down the flanks and toward the base. Prior to each deployment, the proposed transect was overlaid onto a multibeam-derived bathymetric map of the target seamount and displayed on a computer screen on the bridge to assist the ship's officers to manoeuvre the vessel and DTIS vehicle. Positional data for the DTIS vehicle was logged via a Simrad HPR 410 acoustic transponder attached to the steel frame. On conclusion of deployment and recovery of the DTIS vehicle, still image 
data were downloaded from the camera and saved to a storage device. A total of 21

DTIS transects were performed (Table 2.1).

Table 2.1. DTIS transect co-ordinates.

\begin{tabular}{|c|c|c|c|c|c|}
\hline DTIS station & Seamount & Lat. start & Long. start & Lat. end & Long. end \\
\hline 18 & 1 & $48^{\circ} 31^{\prime} 84^{\prime \prime}$ & $164^{\circ} 57^{\prime} 01^{\prime \prime}$ & $48^{\circ} 32^{\prime} 97^{\prime \prime}$ & $164^{\circ} 57^{\prime} 43^{\prime \prime}$ \\
\hline 20 & 1 & $48^{\circ} 33^{\prime} 15^{\prime \prime}$ & $164^{\circ} 56^{\prime} 20^{\prime \prime}$ & $48^{\circ} 34^{\prime} 41^{\prime \prime}$ & $164^{\circ} 56^{\prime} 19^{\prime \prime}$ \\
\hline 32 & 3 & $50^{\circ} 05^{\prime} 71^{\prime \prime}$ & $163^{\circ} 27^{\prime} 66^{\prime \prime}$ & $50^{\circ} 05^{\prime} 73^{\prime \prime}$ & $163^{\circ} 29^{\prime} 36^{\prime \prime}$ \\
\hline 34 & 3 & $50^{\circ} 05^{\prime} 31^{\prime \prime}$ & $163^{\circ} 29^{\prime} 95^{\prime \prime}$ & $50^{\circ} 05^{\prime} 97^{\prime \prime}$ & $163^{\circ} 31^{\prime} 61^{\prime \prime}$ \\
\hline 42 & 4 & $50^{\circ} 38^{\prime} 46^{\prime \prime}$ & $163^{\circ} 48^{\prime} 12^{\prime \prime}$ & $50^{\circ} 39^{\prime} 77^{\prime \prime}$ & $163^{\circ} 49^{\prime} 21^{\prime \prime}$ \\
\hline 43 & 4 & $50^{\circ} 40^{\prime} 05^{\prime \prime}$ & $163^{\circ} 49^{\prime} 56^{\prime \prime}$ & $50^{\circ} 40^{\prime} 93^{\prime \prime}$ & $163^{\circ} 50^{\prime} 27^{\prime \prime}$ \\
\hline 49 & 5 & $51^{\circ} 04^{\prime} 21^{\prime \prime}$ & $161^{\circ} 59^{\prime} 24^{\prime \prime}$ & $51^{\circ} 04^{\prime} 50^{\prime \prime}$ & $162^{\circ} 00^{\prime} 98^{\prime \prime}$ \\
\hline 51 & 5 & $51^{\circ} 04^{\prime} 53^{\prime \prime}$ & $161^{\circ} 58^{\prime} 08^{\prime \prime}$ & $51^{\circ} 05^{\prime} 01^{\prime \prime}$ & $161^{\circ} 56^{\prime} 33^{\prime \prime}$ \\
\hline 64 & 6 & $52^{\circ} 28^{\prime} 69^{\prime \prime}$ & $160^{\circ} 28^{\prime} 74^{\prime \prime}$ & $52^{\circ} 28^{\prime} 52^{\prime \prime}$ & $160^{\circ} 27^{\prime} 65^{\prime \prime}$ \\
\hline 66 & 6 & $52^{\circ} 30^{\prime} 94^{\prime \prime}$ & $160^{\circ} 24^{\prime} 79^{\prime \prime}$ & $52^{\circ} 31^{\prime} 77^{\prime \prime}$ & $160^{\circ} 23^{\prime} 51^{\prime \prime}$ \\
\hline 68 & 6 & $52^{\circ} 22^{\prime} 74^{\prime \prime}$ & $160^{\circ} 40^{\prime} 57^{\prime \prime}$ & $52^{\circ} 23^{\prime} 30^{\prime \prime}$ & $160^{\circ} 41^{\prime} 98^{\prime \prime}$ \\
\hline 70 & 6 & $52^{\circ} 20^{\prime} 07^{\prime \prime}$ & $160^{\circ} 38^{\prime} 37^{\prime \prime}$ & $52^{\circ} 19^{\prime} 77^{\prime \prime}$ & $160^{\circ} 36^{\prime} 94^{\prime \prime}$ \\
\hline 78 & 7 & $53^{\circ} 43^{\prime} 03^{\prime \prime}$ & $159^{\circ} 06^{\prime} 85^{\prime \prime}$ & $53^{\circ} 44^{\prime} 33^{\prime \prime}$ & $159^{\circ} 07^{\prime} 30^{\prime \prime}$ \\
\hline 83 & 7 & $53^{\circ} 44^{\prime} 26^{\prime \prime}$ & $159^{\circ} 08^{\prime} 53^{\prime \prime}$ & $53^{\circ} 44^{\prime} 67^{\prime \prime}$ & $159^{\circ} 09^{\prime} 74^{\prime \prime}$ \\
\hline 90 & 8 & $55^{\circ} 21^{\prime} 11^{\prime \prime}$ & $158^{\circ} 24^{\prime} 66^{\prime \prime}$ & $55^{\circ} 21^{\prime} 19^{\prime \prime}$ & $158^{\circ} 26^{\prime} 35^{\prime \prime}$ \\
\hline 92 & 8 & $55^{\circ} 24^{\prime} 10^{\prime \prime}$ & $158^{\circ} 24^{\prime} 41^{\prime \prime}$ & $55^{\circ} 24^{\prime} 39^{\prime \prime}$ & $158^{\circ} 25^{\prime} 77^{\prime \prime}$ \\
\hline 99 & 9 & $56^{\circ} 14^{\prime} 78^{\prime \prime}$ & $158^{\circ} 29^{\prime} 74^{\prime \prime}$ & $56^{\circ} 15^{\prime} 86^{\prime \prime}$ & $158^{\circ} 28^{\prime} 06^{\prime \prime}$ \\
\hline 101 & 9 & $56^{\circ} 15^{\prime} 55^{\prime \prime}$ & $158^{\circ} 27^{\prime} 43^{\prime \prime}$ & $56^{\circ} 15^{\prime} 45^{\prime \prime}$ & $158^{\circ} 25^{\prime} 70^{\prime \prime}$ \\
\hline 113 & 10 & $59^{\circ} 00^{\prime} 73^{\prime \prime}$ & $158^{\circ} 51^{\prime} 15^{\prime \prime}$ & $59^{\circ} 01^{\prime} 00^{\prime \prime}$ & $158^{\circ} 51^{\prime} 61^{\prime \prime}$ \\
\hline 115 & 10 & $59^{\circ} 00^{\prime} 67^{\prime \prime}$ & $158^{\circ} 52^{\prime} 77^{\prime \prime}$ & $59^{\circ} 01^{\prime} 56^{\prime \prime}$ & $158^{\circ} 54^{\prime} 80^{\prime \prime}$ \\
\hline 126 & 11 & $57^{\circ} 59^{\prime} 16^{\prime \prime}$ & $160^{\circ} 29^{\prime} 33^{\prime \prime}$ & $57^{\circ} 59^{\prime} 57^{\prime \prime}$ & $160^{\circ} 30^{\prime} 92^{\prime \prime}$ \\
\hline
\end{tabular}

\subsubsection{Substrate classification guide}

A guide was developed for this study by the author to ensure consistent classification of seafloor substrate types and is presented in Appendix 2. Images from a total of 21 individual DTIS traverses across the 10 seamounts were classified according to the percent cover of the different substrate types that comprise the imaged area. The data were recorded in Excel spreadsheets. The recognition of different volcanic features was used to investigate the nature of past mid-ocean ridge volcanism and to ground-truth the extent of lithologies sampled by dredging. 


\subsection{GEOCHEMICAL ANALYTICAL TECHNIQUES}

\subsubsection{Sample acquisition and preparation}

\subsubsection{Epibenthic dredge sampling}

Rock samples used in this study were recovered by epibenthic sled dredging of the seafloor of targeted MRC seamounts during voyage TAN0803. Sample stations were selected by a random combination of direction from seamount summit and depth down seamount slope. The epibenthic sled was towed at each station at $1.00-1.15$ knots for a target time of $20 \mathrm{~min}$. A total of 37 dredge transects were undertaken during the voyage. From the material recovered, 39 samples were prepared for petrographic examination, and from these 20 whole rock and 9 volcanic glass samples were selected for chemical analysis (Table 2.2). Samples were chosen for analysis if they appeared to be in situ samples (i.e. not rounded clasts) and had limited hydrothermal alteration. Petrographic descriptions of the 20 whole rock samples are presented in Appendix 3.

\subsubsection{Volcanic glass sample preparation}

Volcanic glass occurring as quenched rinds on pillow lava (5 samples) and hyaloclasts in volcaniclastic breccia (4 samples) was investigated in this study. Glass taken from the samples was crushed into $1-5 \mathrm{~mm}$-long fragments using an agate mortar and pestle. The mortar and pestle were washed with Milli-Q $\mathrm{H}_{2} \mathrm{O}$ (resistivity $>18.2 \mathrm{M} \Omega$ ), processed with a load of quartz sand, and dried with methanol between samples. Samples were subsequently washed in a beaker filled with Milli-Q $\mathrm{H}_{2} \mathrm{O}$ (4 times) and methanol ( 1 time) that was placed in an ultrasonic bath for $3 \mathrm{~min}$ at a time. Glass fragments were rinsed with Milli-Q $\mathrm{H}_{2} \mathrm{O}$ and drained between washes. The chips were then oven-dried at $40^{\circ} \mathrm{C}$ for $24 \mathrm{hr}$. The washing procedure was undertaken in order to remove contamination from salt and seawater that could potentially affect chemical analyses. Petrological features of the washed glass samples were examined by binocular microscopy and fresh, vitreous fragments were picked for electron probe microanalysis (EPMA) and mass spectrometry. Glass 
Table 2.2. Location, type and methods of analysis for dredge samples from the MRC.

\begin{tabular}{|c|c|c|c|c|c|c|}
\hline Sample & SMT & Depth & Latitude & Longitude & Type & \begin{tabular}{|l|} 
Analysis \\
\end{tabular} \\
\hline 31 & 3 & $1150 \mathrm{~m}$ & $50^{\circ} 05^{\prime} 26^{\prime \prime}$ & $163^{\circ} 29^{\prime} 52^{\prime \prime}$ & Basalt & XRF, ICP-MS \\
\hline $33[205]$ & 3 & $1250 \mathrm{~m}$ & $50^{\circ} 05^{\prime} 43^{\prime \prime}$ & $163^{\circ} 28^{\prime} 93^{\prime \prime}$ & Pillow glass & EPMA, ICP-MS \\
\hline $33[206]$ & 3 & $1250 \mathrm{~m}$ & $50^{\circ} 05^{\prime} 43^{\prime \prime}$ & $163^{\circ} 28^{\prime} 93^{\prime \prime}$ & Pillow glass & EPMA, ICP-MS \\
\hline 35 & 3 & $1450 \mathrm{~m}$ & $50^{\circ} 05^{\prime} 80^{\prime \prime}$ & $163^{\circ} 29^{\prime} 51^{\prime \prime}$ & Basalt & XRF, ICP-MS \\
\hline 36 & 3 & $1300 \mathrm{~m}$ & $50^{\circ} 05^{\prime} 92^{\prime \prime}$ & $163^{\circ} 29^{\prime} 10^{\prime \prime}$ & Basalt & XRF, ICP-MS \\
\hline $38 \mathrm{~A}$ & 3 & $1150 \mathrm{~m}$ & $50^{\circ} 05^{\prime} 83^{\prime \prime}$ & $163^{\circ} 28^{\prime} 45^{\prime \prime}$ & Pillow glass & EPMA, ICP-MS \\
\hline $38 \mathrm{~B}$ & 5 & $1150 \mathrm{~m}$ & $50^{\circ} 05^{\prime} 83^{\prime \prime}$ & $163^{\circ} 28^{\prime} 45^{\prime \prime}$ & Basalt & XRF, ICP-MS \\
\hline $48 \mathrm{~A}$ & 5 & $500 \mathrm{~m}$ & $51^{\circ} 05^{\prime} 73^{\prime \prime}$ & $161^{\circ} 58^{\prime} 59^{\prime \prime}$ & Serpentinite & $\mathrm{n} / \mathrm{a}$ \\
\hline $48 \mathrm{~B}$ & 5 & $500 \mathrm{~m}$ & $51^{\circ} 05^{\prime} 73^{\prime \prime}$ & $161^{\circ} 58^{\prime} 59^{\prime \prime}$ & Serpentinite & $\mathrm{n} / \mathrm{a}$ \\
\hline $48 C$ & 5 & $500 \mathrm{~m}$ & $51^{\circ} 05^{\prime} 73^{\prime \prime}$ & $161^{\circ} 58^{\prime} 59^{\prime \prime}$ & Basalt & XRF, ICP-MS \\
\hline 50 & 5 & $450 \mathrm{~m}$ & $51^{\circ} 03^{\prime} 66^{\prime \prime}$ & $161^{\circ} 58^{\prime} 68^{\prime \prime}$ & Serpentinite & $\mathrm{n} / \mathrm{a}$ \\
\hline $52 \mathrm{~A}$ & 5 & $550 \mathrm{~m}$ & $51^{\circ} 02^{\prime} 59^{\prime \prime}$ & $161^{\circ} 58^{\prime} 86^{\prime \prime}$ & Serpentinite & $\mathrm{n} / \mathrm{a}$ \\
\hline $52 B$ & 5 & $550 \mathrm{~m}$ & $51^{\circ} 02^{\prime} 59^{\prime \prime}$ & $161^{\circ} 58^{\prime} 86^{\prime \prime}$ & Basalt & $\mathrm{n} / \mathrm{a}$ \\
\hline $52 \mathrm{C}$ & 5 & $550 \mathrm{~m}$ & $51^{\circ} 02^{\prime} 59^{\prime \prime}$ & $161^{\circ} 58^{\prime} 86^{\prime \prime}$ & Serpentinite & $\mathrm{n} / \mathrm{a}$ \\
\hline 53 & 5 & $400 \mathrm{~m}$ & $51^{\circ} 02^{\prime} 82^{\prime \prime}$ & $162^{\circ} 01^{\prime} 13^{\prime \prime}$ & Gabbro & $\mathrm{n} / \mathrm{a}$ \\
\hline 63 & 6 & $400 m$ & $52^{\circ} 29^{\prime} 24^{\prime \prime}$ & $160^{\circ} 24^{\prime} 90^{\prime \prime}$ & Basalt & XRF, ICP-MS \\
\hline 65 & 6 & $<150 \mathrm{~m}$ & $52^{\circ} 29^{\prime} 82^{\prime \prime}$ & $160^{\circ} 29^{\prime} 35^{\prime \prime}$ & Basalt & XRF, ICP-MS \\
\hline 67 & 6 & $500 \mathrm{~m}$ & $52^{\circ} 27^{\prime} 54^{\prime \prime}$ & $160^{\circ} 25^{\prime} 93^{\prime \prime}$ & Basalt & XRF, ICP-MS \\
\hline $69 \mathrm{~A}$ & 6 & $500 \mathrm{~m}$ & $52^{\circ} 23^{\prime} 85^{\prime \prime}$ & $160^{\circ} 39^{\prime} 40^{\prime \prime}$ & Pillow glass & EPMA, ICP-MS \\
\hline $69 B$ & 6 & $500 \mathrm{~m}$ & $52^{\circ} 23^{\prime} 85^{\prime \prime}$ & $160^{\circ} 39^{\prime} 40^{\prime \prime}$ & Basalt & XRF, ICP-MS \\
\hline $69 C$ & 6 & $500 \mathrm{~m}$ & $52^{\circ} 23^{\prime} 85^{\prime \prime}$ & $160^{\circ} 39^{\prime} 40^{\prime \prime}$ & Breccia & EPMA, ICP-MS \\
\hline 71 & 6 & $450 \mathrm{~m}$ & $52^{\circ} 20^{\prime} 65^{\prime \prime}$ & $160^{\circ} 40^{\prime} 88^{\prime \prime}$ & \begin{tabular}{|l} 
Serpentinite \\
\end{tabular} & $\mathrm{n} / \mathrm{a}$ \\
\hline $77 \mathrm{~A}$ & 7 & $950 \mathrm{~m}$ & $53^{\circ} 44^{\prime} 28^{\prime \prime}$ & $159^{\circ} 06^{\prime} 85^{\prime \prime}$ & Basalt & $\mathrm{n} / \mathrm{a}$ \\
\hline $77 \mathrm{~B}$ & 7 & $950 \mathrm{~m}$ & $53^{\circ} 44^{\prime} 28^{\prime \prime}$ & $159^{\circ} 06^{\prime} 85^{\prime \prime}$ & \begin{tabular}{|l} 
Plutonic \\
\end{tabular} & XRF, ICP-MS \\
\hline 79 & 7 & $800 \mathrm{~m}$ & $53^{\circ} 42^{\prime} 91^{\prime \prime}$ & $159^{\circ} 07^{\prime} 83^{\prime \prime}$ & Basalt & XRF, ICP-MS \\
\hline $82[1241] \mathrm{A}$ & 7 & $1250 \mathrm{~m}$ & $53^{\circ} 43^{\prime} 74^{\prime \prime}$ & $159^{\circ} 09^{\prime} 78^{\prime \prime}$ & Pillow glass & EPMA, ICP-MS \\
\hline $82[1241] B$ & 7 & $1250 \mathrm{~m}$ & $53^{\circ} 43^{\prime} 74^{\prime \prime}$ & $159^{\circ} 09^{\prime} 78^{\prime \prime}$ & Basalt & XRF, ICP-MS \\
\hline $82[1242] \mathrm{A}$ & 7 & $1250 \mathrm{~m}$ & $53^{\circ} 43^{\prime} 74^{\prime \prime}$ & $159^{\circ} 09^{\prime} 78^{\prime \prime}$ & Breccia & EPMA, ICP-MS \\
\hline $82[1242] B$ & 7 & $1250 \mathrm{~m}$ & $53^{\circ} 43^{\prime} 74^{\prime \prime}$ & $159^{\circ} 09^{\prime} 78^{\prime \prime}$ & Basalt & XRF, ICP-MS \\
\hline 84 & 7 & $1000 \mathrm{~m}$ & $53^{\circ} 42^{\prime} 27^{\prime \prime}$ & $159^{\circ} 06^{\prime} 87^{\prime \prime}$ & Basalt & XRF, ICP-MS \\
\hline 89 & 8 & $550 \mathrm{~m}$ & $55^{\circ} 22^{\prime} 87^{\prime \prime}$ & $158^{\circ} 25^{\prime} 59^{\prime \prime}$ & Diabase & XRF. ICP-MS \\
\hline $91 \mathrm{~A}$ & 8 & $500 \mathrm{~m}$ & $55^{\circ} 21^{\prime} 70^{\prime \prime}$ & $158^{\circ} 25^{\prime} 67^{\prime \prime}$ & Diabase & XRF, ICP-MS \\
\hline 91B & 8 & $500 \mathrm{~m}$ & $55^{\circ} 21^{\prime} 70^{\prime \prime}$ & $158^{\circ} 25^{\prime} 67^{\prime \prime}$ & Serpentinite & $\mathrm{n} / \mathrm{a}$ \\
\hline 93 & 8 & $650 \mathrm{~m}$ & $55^{\circ} 21^{\prime} 20^{\prime \prime}$ & $158^{\circ} 26^{\prime} 21^{\prime \prime}$ & Plutonic & XRF, ICP-MS \\
\hline 94 & 8 & $500 \mathrm{~m}$ & $55^{\circ} 22^{\prime} 26^{\prime \prime}$ & $158^{\circ} 23^{\prime} 14^{\prime \prime}$ & Plutonic & XRF, ICP-MS \\
\hline $98 \mathrm{~A}$ & 9 & $700 \mathrm{~m}$ & $56^{\circ} 14^{\prime} 78^{\prime \prime}$ & $158^{\circ} 30^{\prime} 34^{\prime \prime}$ & Breccia & EPMA, ICP-MS \\
\hline $98 \mathrm{~B}$ & 9 & $700 \mathrm{~m}$ & $56^{\circ} 14^{\prime} 78^{\prime \prime}$ & $158^{\circ} 30^{\prime} 34^{\prime \prime}$ & Basalt & XRF, ICP-MS \\
\hline 102 & 9 & $850 \mathrm{~m}$ & $56^{\circ} 14^{\prime} 53^{\prime \prime}$ & $158^{\circ} 27^{\prime} 70^{\prime \prime}$ & Breccia & EPMA, ICP-MS \\
\hline 114 & 10 & $1900 \mathrm{~m}$ & $59^{\circ} 03^{\prime} 90^{\prime \prime}$ & $158^{\circ} 56^{\prime} 08^{\prime \prime}$ & Basalt & XRF, ICP-MS \\
\hline
\end{tabular}

Values for depth, latitude and longitude refer to start of dredge transects. 
chips were set in $32 \mathrm{~mm}$-wide epoxy mounts, which were finely polished and coated with a ca. $25 \mathrm{~nm}$-thick film of carbon prior to introduction to the EPMA sample chamber.

\subsubsection{Whole rock sample preparation}

Whole rock samples were prepared as thin sections for petrological examination by using a diamond saw to cut away altered surfaces and produce billets of fresh, interior rock. The billets were cut to make $100 \mu$ m-thick thin sections. Remaining whole rock material was coarsely crushed into chips $c a .20 \mathrm{~mm}$ in size using a tungsten carbide jaw crusher. Paper towels were placed between crushing plates and samples to avoid metal contamination. Between samples, the jaw crusher was washed with water and a plastic scrubbing brush and dried with methanol.

Given the rocks were collected from the seafloor, these samples required a thorough cleaning procedure to ensure chemical analyses were not affected by any contamination from seawater, salt, sediment or biological matter. Porous volcanic rock samples are especially vulnerable to such effects as the rock interior may be affected by contamination due to the interconnection of vesicles. Crushed rock chips were placed in 1,000 mL beakers filled with ca. $400 \mathrm{~mL}$ of distilled $\mathrm{H}_{2} \mathrm{O}$. Water was repeatedly boiled for 5-10 min at a time. Between repetitions, boiled water was discarded and rock chips were rinsed three times in distilled $\mathrm{H}_{2} \mathrm{O}$. The procedure was repeated until the conductivity of the water closely matched that of the distilled water $(5-10 \mu \mathrm{S})$. Plutonic samples required 5 washes, moderately vesicular basaltic samples required 10 washes and highly vesicular samples required 15 washes.

Whole rock samples were powdered at the University of Canterbury, New Zealand, using an agate swing mill. Approximately $30 \mathrm{~g}$ of sample material (chip size $<15$ $\mathrm{mm}$ ) was placed in the agate mill and run at 650 revolutions per minute (rpm) for 1 min or (longer) until the sample was finely powdered. Between samples the agate mill was: (1) cleaned of remaining sample material with water and dried thoroughly; 
(2) filled with quartz sand and processed for $1 \mathrm{~min}$ at $650 \mathrm{rpm}$; (3) emptied of powdered quartz sand and again washed and dried thoroughly.

\subsubsection{Volcanic glass major element analysis}

\subsubsection{Electron probe microanalysis}

The nine volcanic glass samples were analysed for major elements at Victoria University of Wellington using a JEOL JXA-8230 SuperProbe electron probe microanalyser (EPMA). The JXA-8230 is equipped with five wavelength dispersive X-ray spectrometers (WDS), an energy dispersive X-ray spectrometer (EDS) and highly sensitive detectors for acquisition of backscattered electron (BSE) images.

The EPMA was calibrated for quantitative analysis using international glass standards similar in composition to the sample material. KL2-G (basaltic glass, Kilauea, Hawaii) was used as a primary standard for major element oxides $\mathrm{SiO}_{2}$, $\mathrm{TiO}_{2}, \mathrm{Al}_{2} \mathrm{O}_{3}, \mathrm{MgO}, \mathrm{CaO}, \mathrm{FeO}, \mathrm{K}_{2} \mathrm{O}$ and $\mathrm{Na}_{2} \mathrm{O}$. Beeson apatite was used to calibrate for $\mathrm{P}_{2} \mathrm{O}_{5}$ and a synthetic oxide was used to calibrate for $\mathrm{MnO}$. The instrument was operated under the following settings for analysis of sample and standard glasses: $15 \mathrm{kV}$ accelerating voltage, $8 \mathrm{nA}$ probe current, $20 \mu \mathrm{m}$ spot size. Samples and standards were measured for $30 \mathrm{~s}$ and background levels were measured for $15 \mathrm{~s}$ either side of the peak. Five spots on a homogeneous area of a single grain for pillow lava rind samples were acquired and ten spots on each of at least nine grains from individual breccia samples were analysed. Major element oxide concentrations were calculated using the ZAF method, which corrects for the matrix effects of mass number (Z), absorption (A) and fluorescence (F) that create incorrect element concentration calculations. Petrological features of volcanic glass samples were examined by back-scattered electron (BSE) imaging. 


\subsubsection{Precision and accuracy}

International standards KL2-G (basaltic glass, Kilauea, Hawaii) and VG-A99 (basaltic glass, Makaopuhi, Hawaii) were analysed as unknowns throughout runs in order to monitor instrumental drift and the precision and accuracy of the EPMA analyses. $2 \sigma$ analytical precisions for replicate analyses of $\mathrm{KL} 2-\mathrm{G}$ are $<6 \%$ for all major element oxides, except $\mathrm{MnO}(29 \%)$ and $\mathrm{P}_{2} \mathrm{O}_{5}(20 \%)$. All major oxides are accurate to within $2.5 \%$ of their preferred values for glass standard KL2-G, except $\mathrm{P}_{2} \mathrm{O}_{5}$ (15\%). Approximate $2 \sigma$ analytical precisions for replicate analyses of VG-A99 are $<4 \%$ for all major element oxides, except $\mathrm{MnO}(22 \%), \mathrm{Na}_{2} \mathrm{O}(11 \%)$ and $\mathrm{P}_{2} \mathrm{O}_{5}(13 \%)$. Major element oxides are accurate to within $4 \%$ of their preferred values for glass standard VG-A99, except for $\mathrm{Na}_{2} \mathrm{O}(6.7 \%)$ and $\mathrm{P}_{2} \mathrm{O}_{5}(11 \%)$.

Table 2.3. Precision and accuracy for EPMA analyses of international basaltic glass standards KL2-G $(n=59)$ and VG-A99 ( $n=49)$. Data are in units of wt.\%.

\begin{tabular}{|c|ccc|cc|ccc|c|c|}
\hline & \multicolumn{9}{|c|}{ KL2-G } & \multicolumn{5}{c|}{ VG-A99 } \\
\hline & Average & Pref. Val. & $\%$ Offset & $\mathbf{2 \sigma}$ & $\mathbf{2 \sigma} \%$ & Average & Pref. Val. & $\%$ Offset & $\mathbf{2 \sigma}$ & $\mathbf{2 \sigma} \%$ \\
\hline $\mathrm{SiO}_{2}$ & 50.10 & 50.30 & 0.4 & 0.68 & 1.4 & 50.43 & 51.15 & 1.4 & 0.44 & 0.9 \\
$\mathrm{TiO}_{2}$ & 2.51 & 2.56 & 1.8 & 0.14 & 5.7 & 3.95 & 4.11 & 3.8 & 0.14 & 3.5 \\
$\mathrm{Al}_{2} \mathrm{O}_{3}$ & 13.31 & 13.30 & -0.1 & 0.20 & 1.5 & 12.28 & 12.38 & 0.8 & 0.21 & 1.7 \\
$\mathrm{FeO}_{\mathrm{T}}$ & 10.71 & 10.70 & -0.1 & 0.23 & 2.2 & 13.23 & 13.35 & 0.9 & 0.32 & 2.5 \\
$\mathrm{MnO}$ & 0.17 & 0.17 & -2.0 & 0.05 & 28.5 & 0.20 & 0.20 & 1.2 & 0.04 & 21.6 \\
$\mathrm{MgO}$ & 7.37 & 7.34 & -0.4 & 0.14 & 1.9 & 5.03 & 5.07 & 0.8 & 0.13 & 2.5 \\
$\mathrm{CaO}$ & 10.72 & 10.90 & 1.6 & 0.33 & 3.0 & 8.94 & 9.26 & 3.4 & 0.17 & 2.0 \\
$\mathrm{Na}_{2} \mathrm{O}$ & 2.38 & 2.35 & -1.5 & 0.11 & 4.4 & 2.86 & 2.68 & -6.7 & 0.31 & 10.7 \\
$\mathrm{~K}_{2} \mathrm{O}$ & 0.49 & 0.48 & -2.3 & 0.03 & 5.9 & 0.85 & 0.83 & -1.9 & 0.03 \\
$\mathrm{P}_{2} \mathrm{O}_{5}$ & 0.27 & 0.23 & -14.7 & 0.05 & 20.1 & 0.46 & 0.41 & -11.3 & 0.06 \\
$\mathrm{Total}$ & 98.03 & 98.33 & 0.3 & 1.14 & 1.2 & 98.23 & 99.40 & 1.2 & 0.78 & 12.5 \\
\hline
\end{tabular}

\subsubsection{Whole rock major element analysis}

\subsubsection{X-ray fluorescence spectrometry}

Whole rock major element analysis was carried out by SpectraChem Analytical, CRL Energy Ltd in Lower Hutt, Wellington, New Zealand. Rock sample (20) and standard (2) powders were prepared as fused metaborate glass disks and analysed by X-ray fluorescence (XRF) spectrometry. Major element oxides were measured as weight percent based on $100^{\circ} \mathrm{C}$ oven-dried material, and loss on ignition was calculated based on the weight loss produced by heating to $1,000^{\circ} \mathrm{C}$ for $1 \mathrm{hr}$. 


\subsubsection{Accuracy}

International rock standards BRC-2 (basalt, Columbia River) and BHVO-2 (basalt, Hawaii) were run as unknowns to monitor accuracy of the analyses (Table 2.4). All major element oxides are accurate to within $<2.5 \%$ of their preferred values for both international rock standards, except $\mathrm{MnO}(<12 \%)$ and $\mathrm{P}_{2} \mathrm{O}_{5}(<11 \%)$.

Table 2.4. Accuracy of XRF analyses for international rock standards BCR-2 and BHVO-2. Data are units of wt.\%.

\begin{tabular}{|l|rrr|rrr|}
\hline & \multicolumn{3}{|c|}{ BCR-2 } & \multicolumn{3}{c|}{ BHVO-2 } \\
\hline & Measured & Pref. Val. & \% Offset & Measured & Pref. Val. & \% Offset \\
\hline $\mathrm{SiO}_{2}$ & 54.15 & 54.1 & 0.1 & 49.53 & 49.9 & -0.7 \\
$\mathrm{TiO}_{2}$ & 2.23 & 2.26 & -1.3 & 2.69 & 2.73 & -1.6 \\
$\mathrm{Al}_{2} \mathrm{O}_{3}$ & 13.51 & 13.5 & 0.1 & 13.49 & 13.5 & -0.1 \\
$\mathrm{Fe}_{2} \mathrm{O}_{3}$ & 13.80 & 13.8 & 0.0 & 12.34 & 12.3 & 0.4 \\
$\mathrm{MnO}$ & 0.18 & 0.2 & -9.6 & 0.15 & 0.17 & -12 \\
$\mathrm{MgO}$ & 3.67 & 3.59 & 2.1 & 7.35 & 7.23 & 1.7 \\
$\mathrm{CaO}$ & 7.18 & 7.12 & 0.9 & 11.46 & 11.4 & 0.6 \\
$\mathrm{Na}_{2} \mathrm{O}$ & 3.10 & 3.16 & -1.8 & 2.18 & 2.22 & -2.0 \\
$\mathrm{~K}_{2} \mathrm{O}$ & 1.80 & 1.79 & 0.5 & 0.51 & 0.52 & -1.7 \\
$\mathrm{P}_{2} \mathrm{O}_{5}$ & 0.37 & 0.35 & 6.2 & 0.30 & 0.27 & 11 \\
\hline
\end{tabular}

\subsubsection{Volcanic glass and whole rock trace element analysis}

\subsubsection{Laboratory protocol}

Samples analysed for trace element concentrations were processed in the ultraclean laboratory at Victoria University of Wellington, New Zealand. The ultra-clean laboratory is positively pressured with air filtered to Class 100, and equipped with four PicoTrace Class 10 laminar flow workstations to minimise the risk of terrestrial contamination. All water used throughout laboratory procedures was filtered Millipore ${ }^{\circledR} \mathrm{H}_{2} \mathrm{O}$ (Milli-Q) with resistivity $>18.2 \mathrm{M} \Omega$.

\subsubsection{Sample digestion}

Volcanic glass and whole rock powder samples used in trace element analysis were selected from the same batches of fragments and powders, respectively, that were prepared for major element analysis. Samples and standards were precisely 
weighed (ca. 50-80 mg of material was used) on an ultra-precise balance ( \pm 0.0001 g) and placed into acid-cleaned, savillex screw-top teflon beakers $(23 \mathrm{~mL})$. Sample and standard material were digested by conventional acid digestion methods using ca. $0.5 \mathrm{~mL}$ of concentrated nitric acid (16 $\left.\mathrm{M} \mathrm{HNO}_{3}\right)$ and ca. $2 \mathrm{~mL}$ of concentrated hydrofluoric acid (29 M HF): $\mathrm{HNO}_{3}$ was added first to avoid the formation of fluorides in the sample material. Sealed beakers were placed on a hot plate and heated to $110^{\circ} \mathrm{C}$ for 3-4 days. Following complete digestion of sample and standard material, the solution was evaporated to incipient dryness, refluxed three times in ca. $2 \mathrm{~mL}$ of concentrated $\mathrm{HNO}_{3}$ for $24 \mathrm{hr}$ at a time and again evaporated to incipient dryness. Sample cakes were then refluxed in $5 \mathrm{~mL}$ of $6 \mathrm{M} \mathrm{HCl}$ for $c a .24 \mathrm{hr}$. The $\mathrm{HCl}$ was evaporated and the sample cake was refluxed two more times in ca. $2 \mathrm{~mL}$ of concentrated $\mathrm{HNO}_{3}$ acid for $24 \mathrm{hr}$ at a time, before being evaporated to incipient dryness again. The dried sample was then taken up in $9 \mathrm{~mL}$ of $1 \mathrm{M}$ nitric acid and refluxed for 2-3 days to form a final solution. Beakers were taken off the hot-plate to cool before being centrifuged at $1500 \mathrm{rpm}$ for $5 \mathrm{~min}$ to ensure that all sample material had been digested and no solids remained. This final solution was carefully transferred to $10 \mathrm{~mL}$ polyethylene centrifuge tubes (c-tubes), making sure all drops were removed from the beaker, and precisely weighed $( \pm 0.0001 \mathrm{~g}$ ) on a highprecision balance. The c-tubes were pre-cleaned by rinsing three times with Milli-Q $\mathrm{H}_{2} \mathrm{O}$ then stored for 1-2 weeks in $9 \mathrm{~mL}$ of Milli-Q $\mathrm{H}_{2} \mathrm{O}$ and ca. $0.2 \mathrm{~mL}$ of concentrated $\mathrm{HNO}_{3}$. After storage, the tubes were emptied, rinsed three times with Milli-Q $\mathrm{H}_{2} \mathrm{O}$ and thoroughly dried.

\subsubsection{Sample dilution}

To form a dilution of the sample, a $50 \mu \mathrm{L}$ aliquot of each $9 \mathrm{~mL}$ sample solution was placed into the remaining empty tubes and precisely weighed. Each aliquot was then diluted with $6 \mathrm{~mL}$ of $1 \% \mathrm{HNO}_{3}$ and again precisely weighed in order to accurately determine the dilution factor of the sample material. 


\subsubsection{Mass spectrometry}

Sample and standard dilutions were analysed for trace element concentrations by solution inductively coupled plasma mass spectrometry (ICP-MS) using an Agilent 7500CS ICP-MS at Victoria University of Wellington. Solutions were drawn into the nebuliser by a peristaltic pump. ICP-MS instrumental conditions (torch position and carrier/make-up gas flow) were adjusted to achieve optimal sensitivity while aspirating an Agilent $1 \mathrm{ppb}$ multi-element standard solution (Table 2.5). Oxide generation was monitored by measuring $\mathrm{CeO}^{+} / \mathrm{Ce}^{+}$ratios $(<1 \%)$. Multiple isotopes for some elements (e.g. ${ }^{90} \mathrm{Zr},{ }^{91} \mathrm{Zr} ;{ }^{151} \mathrm{Eu},{ }^{153} \mathrm{Eu}$ ) were acquired in the analysis to test data quality ( $<3 \%$ offset between isotopes for same sample or standard). The ICPMS changes from pulse to analog counting modes to allow for switching between measurement of elements present in low and high concentrations, respectively. Pulse to analog $(\mathrm{P} / \mathrm{A})$ factors were measured prior to analysis on relevant elements to ensure the ICP-MS made the correct adjustments between counting modes during the run. Standard and sample dilutions were measured for $120 \mathrm{~s}$. Prior to each measurement, the ICP-MS was washed out with Milli-Q $\mathrm{H}_{2} \mathrm{O}$ for $30 \mathrm{~s}, 1 \% \mathrm{HNO}_{3}$ for $90 \mathrm{~s}$, and $1 \% \mathrm{HNO}_{3}$ (measured as the background) for $30 \mathrm{~s}$. Trace element concentrations were measured using a sample-standard bracketing method. Thus, the analysis procedure followed a sequence starting with the calibration standard (BCR-2a) followed by two samples, one of the secondary standards (BCR-2b or BHVO-2, used alternatively throughout the run), two more samples, and finally the calibration standard (BCR-2a), representing the start of the next sequence.

\subsubsection{Data reduction and concentration calculation}

Individual trace element concentrations were measured relative to a matrixmatched bracketing standard (BCR-2), which was analysed throughout the run. Background count rates (counts per second; CPS) were measured for $30 \mathrm{~s}$ during washout of $1 \% \mathrm{HNO}_{3}$. The mean background was subtracted from the count rates during sample analysis (120 s per sample, standard). Background-corrected count 
Table 2.5. ICP-MS instrumental and analytical conditions.

\begin{tabular}{|c|c|}
\hline ICP-MS & \\
\hline System & Agilent 7500 cs octopole \\
\hline Acquisition mode & Peak hopping \\
\hline Detection mode & Pulse and analog \\
\hline \multicolumn{2}{|l|}{ Standards and calibration } \\
\hline Bracketing standard & BCR-2 \\
\hline Secondary standards & BCR-2 and BHVO-2 \\
\hline \multicolumn{2}{|l|}{ Analysis } \\
\hline Background acquisition & $30 \mathrm{~s}\left(1 \% \mathrm{HNO}_{3}\right)$ \\
\hline Sample/standard acquisition & $120 \mathrm{~s}$ \\
\hline Washout times & 1) $\mathrm{H}_{2} \mathrm{O} 30 \mathrm{~s}$ \\
\hline & 2) $1 \% \mathrm{HNO}_{3} 90 \mathrm{~s}$ \\
\hline Measured isotopes & $\begin{array}{l}{ }^{7} \mathrm{Li},{ }^{25} \mathrm{Mg},{ }^{43} \mathrm{Ca},{ }^{45} \mathrm{Sc},{ }^{47} \mathrm{Ti},{ }^{51} \mathrm{~V},{ }^{53} \mathrm{Cr},{ }^{59} \mathrm{Co},{ }^{60} \mathrm{Ni},{ }^{63} \mathrm{Cu},{ }^{66} \mathrm{Zn},{ }^{71} \mathrm{Ga},{ }^{85} \mathrm{Rb}, \\
{ }^{88} \mathrm{Sr},{ }^{89} \mathrm{Y},{ }^{90} \mathrm{Zr},{ }^{91} \mathrm{Zr},{ }^{93} \mathrm{Nb},{ }^{95} \mathrm{Mo},{ }^{133} \mathrm{Cs},{ }^{137} \mathrm{Ba},{ }^{139} \mathrm{La},{ }^{140} \mathrm{Ce},{ }^{141} \mathrm{Pr},{ }^{146} \mathrm{Nd}, \\
{ }^{147} \mathrm{Sm},{ }^{151} \mathrm{Eu},{ }^{153} \mathrm{Eu},{ }^{157} \mathrm{Gd},{ }^{159} \mathrm{~Tb},{ }^{163} \mathrm{Dy},{ }^{165} \mathrm{Ho},{ }^{166} \mathrm{Er},{ }^{169} \mathrm{Tm},{ }^{172} \mathrm{Yb},{ }^{175} \mathrm{Lu}, \\
{ }^{178} \mathrm{Hf},{ }^{181} \mathrm{Ta},{ }^{205} \mathrm{Tl},{ }^{208} \mathrm{~Pb},{ }^{232} \mathrm{Th},{ }^{238} \mathrm{U}\end{array}$ \\
\hline \multicolumn{2}{|l|}{ Tuning } \\
\hline Tuning standard & Agilent $1 \mathrm{ppb}$ solution \\
\hline Monitored isotopes & ${ }^{7} \mathrm{Li},{ }^{59} \mathrm{Co},{ }^{89} \mathrm{Y},{ }^{140} \mathrm{Ce},{ }^{205} \mathrm{Tl}(\% \mathrm{RSD}<3 \%)$ \\
\hline Calibration standards & BCR-2, BHVO-2 \\
\hline Monitored isotopes & ${ }^{7} \mathrm{Li},{ }^{24} \mathrm{Mg},{ }^{43} \mathrm{Ca},{ }^{51} \mathrm{~V},{ }^{60} \mathrm{Ni},{ }^{66} \mathrm{Zn},{ }^{88} \mathrm{Sr},{ }^{140} \mathrm{Ce},{ }^{208} \mathrm{~Pb},{ }^{238} \mathrm{U}$ (\% RSD <5\%) \\
\hline Oxides & $\mathrm{CeO}^{+} / \mathrm{Ce}^{+} 10 \mathrm{ppb}$ solution $(<1 \%)$ \\
\hline Carrier gas (Ar) & $1.08-1.12 \mathrm{~L} / \mathrm{min}$ \\
\hline Make-up gas (Ar) & $0 \mathrm{~L} / \mathrm{min}$ \\
\hline RF power & $1500 \mathrm{~W}$ \\
\hline RF matching & $1.72-1.77 \mathrm{~V}$ \\
\hline Sample depth & $7 \mathrm{~mm}$ \\
\hline
\end{tabular}


rates for each sample were converted to concentrations based on the bracketing standard using the following equations:

1. Sample $C_{i}=\left(\right.$ Sample $_{\text {CPS }} /$ BCR-2 CPS $) \times\left(\right.$ Sample $_{\text {Dil }} /$ BCR- -2 Dil $) \times$ ref. value

2. Sample $C_{i}($ Ca corrected $)=$ Sample $C_{i}($ from 1. above $) \times\left(C_{C a 1} / C_{C a 2}\right)$

where $C_{i}$ is the concentration of element $i$ and $X_{D i l}$ is the concentration of material in the aliquot dilution. $\mathrm{C}_{\mathrm{Ca}}$ is the concentration of $\mathrm{Ca}$ from 1) EPMA or XRF and 2) ICPMS analysis. Reference values for BCR-2 were acquired from the GeoReM preferred values database (http://georem.mpch-mainz.gwdg.de/sample_query_pref.asp).

\subsubsection{Precision and accuracy of ICP-MS trace element analysis}

International rock standards BCR-2b (basalt, Columbia River; prepared as a separate digestion from the calibration standard BCR-2a) and BHVO-2 (basalt, Hawaii) were run as secondary standards at regular intervals throughout analysis sessions in order to assess accuracy and precision of solution ICP-MS trace element analyses. A sample duplicate was also prepared and analysed during each analysis session to further assess the accuracy of ICP-MS trace element analyses.

$2 \sigma$ analytical precisions from replicate analyses of BCR-2 are generally $<10 \%$ for most trace elements (Table 2.6). Exceptions are Li (18.3\%), Cr (15.3\%), Ta (21.0\%) and $\mathrm{Tl}(12.3 \%)$. All trace elements measured for BCR-2 are accurate to within $6 \%$ (most are $<1 \%$ ) of the reference values, except Ta $(12.7 \%)$. The anomalous value for Li from digestion A1 appears to be an outlier, which lowered the analytical precision and accuracy of Li (Table 2.6). Poor analytical accuracy and precision for Ta and $\mathrm{Tl}$ is due to the low concentrations of these elements in the standard material. Approximate $2 \sigma$ analytical precisions from replicate analyses of BHVO-2 are $<6 \%$ for most trace elements (Table 2.7). Exceptions are $\mathrm{Cr}(10.6 \%), \mathrm{Cu}$ (12.6\%), Nb (13.8\%), Mo (34.5\%), Cs (17.2\%), Ta (18.0\%) and Tl (70.9\%). Trace elements measured for BHVO-2 are generally accurate to within $<6 \%$ (many are $<1 \%$ ) of the reference value (Table 2.7). Exceptions to this level of accuracy are Li (8.2\%), Cr (25.8\%), Cu (12.7\%), Mo (18.7\%) and Ta (12.3\%). 
Analysis of a duplicate digestion of one sample was performed for each ICP-MS run. Values of \% offset between analyses of duplicate digestions are presented in Table 2.8. For run A, all trace elements measured in the replicate digestions are accurate to within 6\%, except $\mathrm{Tl}(19.3 \%)$ due to its very low concentration in the sample material. For run B, all trace elements measured in the replicate digestions are accurate to within $5 \%$, except $\mathrm{Cu}(10.9 \%)$ and (due to an anomalous value measured for digestion B1) Zn (39.4\%). For run C, most trace elements measured in the replicate digestions are accurate to within $3 \%$, and many to within $1 \%$. Exceptions are $\mathrm{Li}(7.9 \%), \mathrm{Cu}(6.4 \%), \mathrm{Ba}(24.0 \%), \mathrm{Tl}(32.1 \%)$ and $\mathrm{Pb}(55.4 \%)$. The analytical accuracy was lessened for these elements due to anomalous values for $\mathrm{Ba}$ and $\mathrm{Pb}$, and very low concentrations for $\mathrm{Tl}$. 


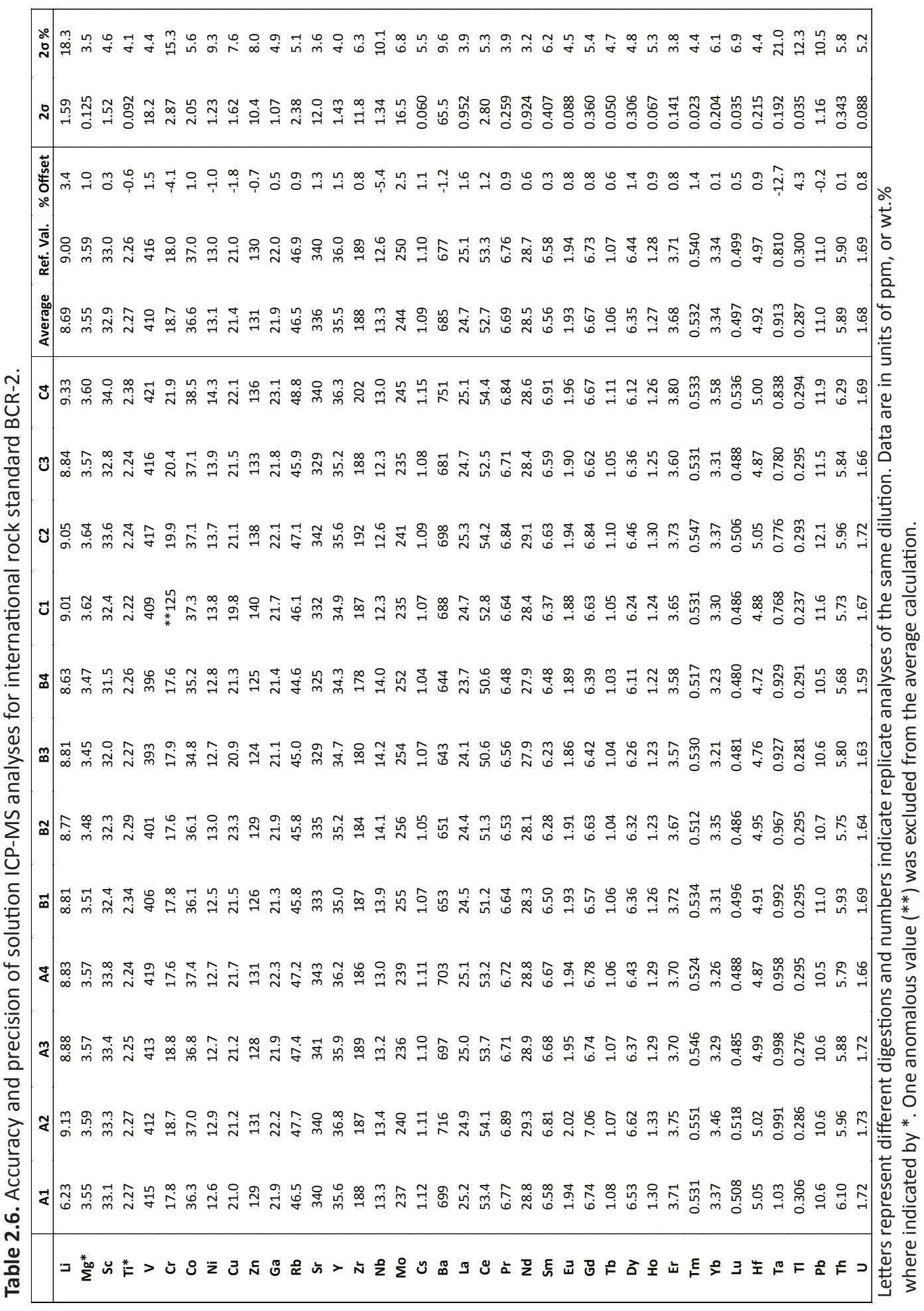


Table 2.7. Accuracy and precision of solution ICP-MS analyses for international rock standard BHVO-2.

\begin{tabular}{|c|c|c|c|c|c|c|c|c|c|c|c|}
\hline & A1 & A2 & B1 & B2 & C1 & C2 & Average & Ref. Val & $\%$ Offset & $2 \sigma$ & $2 \sigma \%$ \\
\hline Li & 4.38 & 4.34 & 4.57 & 4.40 & 4.44 & 4.31 & 4.41 & 4.80 & 8.2 & 0.181 & 4.1 \\
\hline Mg* & 7.21 & 7.16 & 7.06 & 6.81 & 7.37 & 7.16 & 7.13 & 7.23 & 1.4 & 0.370 & 5.2 \\
\hline Sc & 30.7 & 30.8 & 30.7 & 30.4 & 31.8 & 31.2 & 30.9 & 32.0 & 3.4 & 0.957 & 3.1 \\
\hline $\mathrm{Ti}^{*}$ & 2.67 & 2.67 & 2.73 & 2.70 & 2.71 & 2.68 & 2.69 & 2.73 & 1.3 & 0.045 & 1.7 \\
\hline v & 314 & 314 & 305 & 300 & 318 & 314 & 311 & 317 & 2.0 & 13.3 & 4.3 \\
\hline $\mathrm{Cr}$ & 342 & 361 & 334 & 331 & 375 & 370 & 352 & 280 & -25.8 & 37.4 & 10.6 \\
\hline Co & 44.2 & 43.7 & 42.9 & 42.1 & 44.1 & 43.9 & 43.5 & 45.0 & 3.4 & 1.63 & 3.8 \\
\hline $\mathrm{Ni}$ & 127 & 126 & 128 & 124 & 128 & 129 & 127 & 119 & -6.7 & 3.95 & 3.1 \\
\hline $\mathrm{Cu}$ & 139 & 140 & 161 & 144 & 137 & 138 & 143 & 127 & -12.7 & 18.0 & 12.6 \\
\hline $\mathrm{Zn}$ & 100 & 99.1 & 100 & 97 & 104 & 104 & 101 & 103 & 2.0 & 5.72 & 5.7 \\
\hline Ga & 21.0 & 21.0 & 20.6 & 20.1 & 21.3 & 21.1 & 20.8 & 22.0 & 5.3 & 0.886 & 4.3 \\
\hline $\mathbf{R b}$ & 8.92 & 9.01 & 8.80 & 8.71 & 9.02 & 8.90 & 8.89 & 9.11 & 2.4 & 0.244 & 2.7 \\
\hline $\mathrm{Sr}$ & 384 & 392 & 384 & 381 & 395 & 384 & 387 & 396 & 2.4 & 11.5 & 3.0 \\
\hline$Y$ & 26.0 & 26.0 & 25.3 & 25.1 & 25.7 & 25.4 & 25.6 & 26.0 & 1.6 & 0.771 & 3.0 \\
\hline $\mathrm{Zr}$ & 168 & 172 & 168 & 165 & 173 & 170 & 169 & 172 & 1.5 & 5.71 & 3.4 \\
\hline $\mathrm{Nb}$ & 18.0 & 18.5 & 20.7 & 20.8 & 18.3 & 18.1 & 19.1 & 18.1 & -5.4 & 2.64 & 13.8 \\
\hline Mo & 3.79 & 3.83 & 5.66 & 5.62 & 4.83 & 4.75 & 4.75 & 4.00 & -18.7 & 1.64 & 34.5 \\
\hline Cs & 0.104 & 0.106 & 0.088 & 0.089 & 0.090 & 0.090 & 0.095 & 0.100 & 5.3 & 0.016 & 17.2 \\
\hline $\mathrm{Ba}$ & 127 & 129 & 128 & 126 & 131 & 129 & 128 & 131 & 2.1 & 3.59 & 2.8 \\
\hline La & 14.8 & 15.1 & 14.7 & 14.5 & 15.1 & 15.0 & 14.8 & 15.2 & 2.3 & 0.509 & 3.4 \\
\hline $\mathrm{Ce}$ & 36.7 & 37.9 & 36.9 & 36.4 & 37.3 & 37.0 & 37.0 & 37.5 & 1.3 & 1.04 & 2.8 \\
\hline $\mathrm{Pr}$ & 5.23 & 5.34 & 5.11 & 5.14 & 5.30 & 5.23 & 5.23 & 5.35 & 2.3 & 0.174 & 3.3 \\
\hline $\mathrm{Nd}$ & 24.1 & 24.6 & 24.4 & 24.0 & 24.2 & 24.2 & 24.3 & 24.5 & 1.0 & 0.439 & 1.8 \\
\hline Sm & 6.11 & 6.26 & 5.84 & 5.82 & 5.97 & 5.95 & 5.99 & 6.07 & 1.3 & 0.335 & 5.6 \\
\hline Eu & 1.96 & 1.97 & 1.99 & 1.96 & 1.99 & 1.97 & 1.97 & 2.07 & 4.8 & 0.027 & 1.4 \\
\hline Gd & 6.22 & 6.15 & 6.06 & 5.83 & 6.03 & 5.98 & 6.05 & 6.24 & 3.1 & 0.271 & 4.5 \\
\hline Tb & 0.897 & 0.949 & 0.916 & 0.915 & 0.943 & 0.929 & 0.925 & 0.920 & -0.5 & 0.039 & 4.2 \\
\hline Dy & 5.22 & 5.31 & 5.25 & 5.19 & 5.29 & 5.29 & 5.26 & 5.31 & 1.0 & 0.094 & 1.8 \\
\hline Ho & 0.956 & 0.976 & 0.939 & 0.937 & 0.968 & 0.955 & 0.955 & 0.980 & 2.5 & 0.031 & 3.3 \\
\hline $\mathrm{Er}$ & 2.51 & 2.55 & 2.55 & 2.47 & 2.52 & 2.52 & 2.52 & 2.54 & 0.8 & 0.059 & 2.4 \\
\hline $\mathrm{Tm}$ & 0.342 & 0.353 & 0.328 & 0.338 & 0.342 & 0.343 & 0.341 & 0.330 & -3.4 & 0.016 & 4.8 \\
\hline $\mathrm{Yb}$ & 2.02 & 1.99 & 1.95 & 1.89 & 1.95 & 1.95 & 1.96 & 2.00 & 2.1 & 0.086 & 4.4 \\
\hline Lu & 0.276 & 0.271 & 0.264 & 0.263 & 0.265 & 0.262 & 0.267 & 0.274 & 2.7 & 0.011 & 3.9 \\
\hline $\mathrm{Hf}$ & 4.37 & 4.50 & 4.41 & 4.25 & 4.37 & 4.34 & 4.37 & 4.36 & -0.3 & 0.162 & 3.7 \\
\hline Ta & 1.34 & 1.38 & 1.37 & 1.32 & 1.13 & 1.14 & 1.28 & 1.14 & -12.3 & 0.231 & 18.0 \\
\hline TI & 0.045 & 0.046 & 0.027 & 0.026 & 0.021 & 0.023 & 0.031 & - & - & 0.022 & 70.9 \\
\hline $\mathrm{Pb}$ & 1.49 & 1.51 & 1.57 & 1.55 & 1.55 & 1.53 & 1.53 & 1.60 & 4.1 & 0.061 & 4.0 \\
\hline Th & 1.17 & 1.19 & 1.19 & 1.20 & 1.21 & 1.21 & 1.19 & 1.22 & 2.1 & 0.029 & 2.4 \\
\hline U & 0.417 & 0.423 & 0.407 & 0.404 & 0.412 & 0.415 & 0.413 & 0.403 & -2.5 & 0.014 & 3.4 \\
\hline
\end{tabular}

Letters represent different digestions and numbers indicate replicate analyses of the same dilution. Data are in units of ppm, or wt.\% where indicate by *. 
Table 2.8. Analytical repeatability for solution ICP-MS analyses of duplicate digestions of samples.

\begin{tabular}{|c|c|c|c|c|c|c|c|c|c|}
\hline & A1 & $A 2$ & $\%$ Offset & B1 & B2 & \% Offset & C1 & C2 & $\%$ Offset \\
\hline Li & 9.42 & 9.43 & 0.1 & 12.6 & 12.1 & -4.4 & 5.06 & 5.47 & 7.9 \\
\hline Mg* & 9.34 & 9.34 & 0.0 & 7.31 & 7.04 & -3.8 & 8.09 & 8.15 & 0.7 \\
\hline Sc & 33.7 & 32.9 & -2.4 & 38.7 & 38.7 & 0.1 & 36.7 & 37.5 & 2.2 \\
\hline $\mathrm{Ti}^{*}$ & 1.53 & 1.52 & -0.6 & 1.17 & 1.17 & -0.7 & 1.25 & 1.29 & 2.7 \\
\hline v & 226 & 220 & -2.3 & 262 & 263 & 0.4 & 262 & 266 & 1.5 \\
\hline $\mathrm{Cr}$ & 635 & 647 & 1.9 & 230 & 229 & -0.6 & 389 & 388 & -0.2 \\
\hline Co & 41.7 & 41.5 & -0.4 & 43.5 & 43.1 & -0.9 & 40.3 & 40.6 & 0.6 \\
\hline $\mathrm{Ni}$ & 269 & 265 & -1.4 & 110 & 105 & -4.2 & 133 & 134 & 0.7 \\
\hline $\mathrm{Cu}$ & 78.8 & 76.0 & -3.6 & 101 & 90.2 & -10.9 & 73.5 & 78.2 & 6.4 \\
\hline $\mathrm{Zn}$ & 61.5 & 61.2 & -0.5 & 115 & 69.8 & -39.4 & 71.4 & 69.8 & -2.2 \\
\hline Ga & 15.5 & 15.0 & -3.6 & 15.6 & 15.2 & -3.1 & 15.2 & 15.3 & 0.8 \\
\hline $\mathbf{R b}$ & 11.3 & 11.2 & -0.7 & 3.46 & 3.43 & -0.9 & 4.47 & 4.53 & 1.3 \\
\hline $\mathrm{Sr}$ & 330 & 317 & -3.9 & 131 & 128 & -2.4 & 124 & 123 & -0.2 \\
\hline$Y$ & 22.6 & 22.7 & 0.3 & 26.1 & 25.8 & -0.9 & 27.8 & 28.3 & 1.8 \\
\hline $\mathrm{Zr}$ & 134 & 129 & -4.0 & 69.8 & 69.7 & -0.2 & 83.7 & 85.1 & 1.6 \\
\hline $\mathrm{Nb}$ & 42.8 & 42.3 & -1.1 & 9.60 & 9.78 & 1.9 & 8.89 & 9.15 & 2.9 \\
\hline Mo & 0.618 & 0.646 & 4.0 & 0.465 & 0.453 & -2.6 & 0.437 & 0.435 & -0.3 \\
\hline Cs & 0.105 & 0.108 & 3.0 & 0.136 & 0.143 & 5.1 & 0.047 & 0.048 & 3.0 \\
\hline $\mathrm{Ba}$ & 184 & 185 & 0.9 & 49.3 & 49.2 & -0.2 & 61.2 & 46.6 & -24.0 \\
\hline La & 20.3 & 19.2 & -5.6 & 5.55 & 5.45 & -1.8 & 6.10 & 6.10 & 0.0 \\
\hline $\mathrm{Ce}$ & 39.5 & 39.3 & -0.5 & 12.9 & 13.0 & 0.4 & 14.4 & 14.4 & 0.0 \\
\hline $\mathrm{Pr}$ & 4.83 & 4.79 & -0.9 & 1.77 & 1.84 & 3.9 & 2.07 & 2.07 & -0.2 \\
\hline Nd & 20.2 & 19.7 & -2.0 & 9.09 & 9.00 & -0.9 & 10.4 & 10.2 & -1.8 \\
\hline Sm & 4.21 & 4.43 & 5.3 & 2.76 & 2.82 & 2.3 & 3.19 & 3.14 & -1.5 \\
\hline Eu & 1.44 & 1.42 & -1.4 & 1.01 & 1.01 & 0.3 & 1.08 & 1.10 & 1.6 \\
\hline Gd & 4.57 & 4.55 & -0.5 & 3.64 & 3.53 & -3.1 & 3.91 & 3.98 & 1.8 \\
\hline Tb & 0.696 & 0.675 & -3.1 & 0.655 & 0.664 & 1.5 & 0.731 & 0.729 & -0.3 \\
\hline Dy & 4.15 & 4.12 & -0.7 & 4.49 & 4.53 & 0.9 & 4.84 & 4.82 & -0.4 \\
\hline Ho & 0.803 & 0.813 & 1.2 & 0.933 & 0.925 & -0.8 & 1.01 & 1.01 & -0.2 \\
\hline $\mathrm{Er}$ & 2.36 & 2.34 & -1.3 & 2.76 & 2.73 & -1.2 & 2.96 & 3.02 & 2.0 \\
\hline $\mathrm{Tm}$ & 0.332 & 0.333 & 0.5 & 0.398 & 0.419 & 5.2 & 0.446 & 0.448 & 0.4 \\
\hline $\mathrm{Yb}$ & 2.10 & 2.10 & 0.3 & 2.66 & 2.53 & -4.8 & 2.77 & 2.76 & -0.5 \\
\hline Lu & 0.307 & 0.302 & -1.6 & 0.382 & 0.388 & 1.6 & 0.415 & 0.417 & 0.4 \\
\hline $\mathrm{Hf}$ & 3.21 & 3.09 & -3.8 & 1.95 & 1.91 & -2.1 & 2.25 & 2.24 & -0.2 \\
\hline $\mathrm{Ta}$ & 3.32 & 3.14 & -5.4 & 0.627 & 0.599 & -4.4 & 0.545 & 0.546 & 0.1 \\
\hline TI & 0.024 & 0.020 & -19.3 & 0.242 & 0.232 & -4.3 & 0.018 & 0.012 & -32.1 \\
\hline $\mathrm{Pb}$ & 1.08 & 1.06 & -2.1 & 0.558 & 0.586 & 5.0 & 0.514 & 0.799 & 55.4 \\
\hline Th & 2.73 & 2.58 & -5.7 & 0.642 & 0.653 & 1.8 & 0.666 & 0.678 & 1.8 \\
\hline $\mathbf{u}$ & 0.459 & 0.460 & 0.1 & 0.253 & 0.255 & 0.7 & 0.176 & 0.174 & -1.4 \\
\hline
\end{tabular}

Letters represent different samples and numbers indicate replicate digestions. Data are in units of ppm, or wt.\% where indicated by *. 


\section{CHAPTER 3:}

\section{EVOLUTION OF MACQUARIE RIDGE COMPLEX SEAMOUNTS}

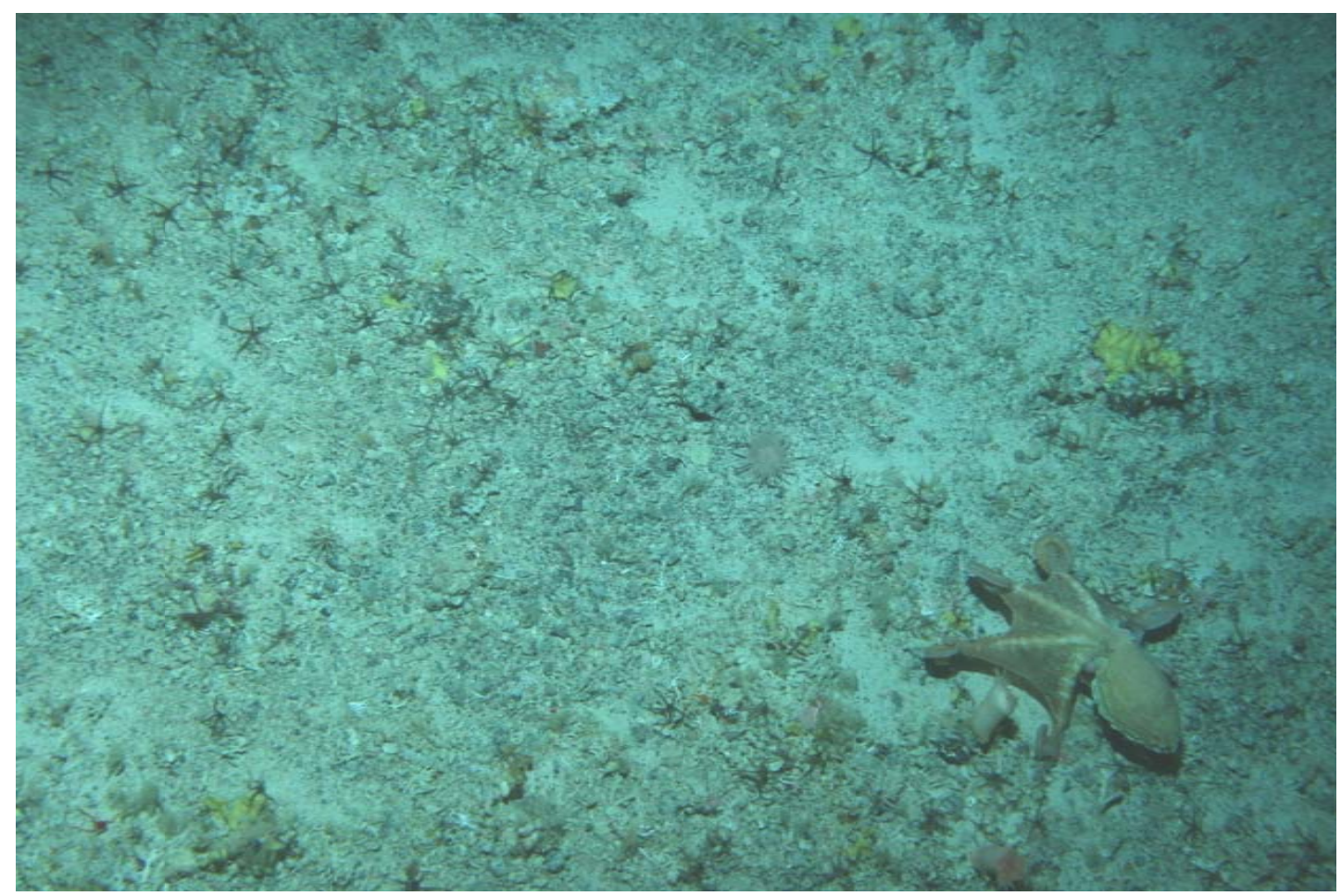

Plate 4. An octopus spreads out on the substrate of seamount 6.

Note: This chapter was prepared as an article for submission to Marine Geology

Evolution of Macquarie Ridge Complex seamounts: Implications for volcanic and tectonic processes at the Australia-Pacific plate boundary south of New Zealand

Chris E. Conway ${ }^{1 *}$, Joel A. Baker ${ }^{1}$, Helen C. Bostock ${ }^{2}$, Richard J. Wysoczanski ${ }^{2}$, AnneLaure Verdier ${ }^{2}$

${ }^{1}$ Victoria University of Wellington, PO Box 600, New Zealand, ${ }^{2}$ National Institute of Water and Atmospheric Research, PO Box 14 901, Wellington, New Zealand 


\section{ABSTRACT}

The Macquarie Ridge Complex coincides with the Australia-Pacific plate boundary south of New Zealand and is characterised by a rugged bathymetry that comprises numerous seamounts along its length. Tectonic plate reconstructions show that the Australia-Pacific plate boundary evolved from a spreading centre to a transpressional boundary from ca. 40 to $6 \mathrm{Ma}$. However, limited high-resolution sampling and multibeam mapping of the region has meant that the composition and morphology of the Macquarie Ridge Complex remains relatively unknown. Here we present results from multibeam mapping, photographic investigation and petrologic and geochemical analyses of the region's seafloor at 10 seamounts along the Macquarie Ridge Complex. Dredge samples collected from the seamounts are alkaline to sub-alkaline basalts, containing $45.1-50.8$ wt.\% $\mathrm{SiO}_{2}, 3.5-12.0$ wt.\% $\mathrm{MgO}$ and $1.9-4.9$ wt.\% total alkalis. All samples are enriched mid-ocean ridge basalts that have $\mathrm{K} / \mathrm{Ti}>0.15$, which originated as low degree partial melts during the late stages of mid-ocean ridge volcanism at the plate boundary. This oceanic crust has been sheared and accreted along the plate boundary since $c a$. $6 \mathrm{Ma}$ by cumulative transpressional relative plate motion, such that lavas from distinct magma chambers have been juxtaposed at individual seamounts along the ridge. MRC seamounts have formed as discrete elevations as a result of dip-slip and strikeslip faulting of the ridge axis. Three guyot-type seamounts have flat-top summit plateaux that were presumably formed by wave erosion when their crests were at or near sea-level. These seamounts have since subsided due to extension associated with the step-over fault geometry of the transform plate boundary along the McDougall and Macquarie ridge segments. While the seamounts are of volcanic origin, they are manifestations of tectonic and geomorphic processes. Seamounts distal from the plate boundary, however, are not subjected to plate boundary deformation and instead have morphologies formed through volcanic processes. 


\subsection{INTRODUCTION}

Oceanic plate boundaries are regions on Earth's surface where crust is created, deformed and recycled into the mantle depending on the relative motion of the lithospheric plates. Tectonic plate motions have changed through time and understanding the evolution of plate boundaries is critical in tracing the origins of Earth's landmasses and oceans. Modelling such a plate boundary evolution involves reconstruction of past relative plate motion using the geomagnetic timescale, while constraining these models requires geological observations. The Australia-Pacific plate boundary south of New Zealand has undergone an extensive and rapid evolution, encompassing divergent, transform and convergent relative plate motions throughout the last 40 Myr of its history (Walcott, 1984). This evolution has been well-documented by kinematic plate reconstructions combined with marine geophysical surveys and field evidence from Macquarie Island (e.g. Lamarche et al., 1997; Massell et al., 2000; Wertz et al., 2003). However, observational evidence for the products of past seafloor spreading and current transform and convergent relative plate motion remains scarce for this remote region of the Southwest Pacific. In this paper we present a detailed geological dataset for 10 seamounts of the Macquarie Ridge Complex (MRC) in order to define the morphology and composition of the ridge. The eruptive style of mid-ocean ridge volcanism at the past divergent plate boundary, and the composition of the modern ridge, is revealed by photographic investigation of the MRC seafloor and petrologic and major element chemical analyses of volcanic glass and whole rock samples acquired from the most comprehensive submarine dredge operation of the MRC to date. The combination of high-resolution bathymetry and backscatter mapping of the ridge reveals modes of crustal deformation and the associated effect on the morphology of the MRC.

\subsection{GEOLOGIC SETTING OF THE MACQUARIE RIDGE COMPLEX}

The Macquarie Ridge Complex (MRC) forms the submarine expression of the Australia-Pacific plate boundary south of New Zealand and is a prominent 1,600 km- 
long bathymetric ridge in the Southern Ocean (Fig. 3.1 inset). The MRC comprises four segments; from north to south these are the Puysegur, McDougall, Macquarie, and Hjort segments (Fig. 3.1; Massell et al., 2000). The ridge crest has a rugged bathymetry as it undulates from $100 \mathrm{~m}$ to $>1,000 \mathrm{~m}$ below sea-level along its length. Macquarie Island $\left(54^{\circ} 30^{\prime} \mathrm{S}\right)$ is the sole subaerial exposure of the MRC and is located on the Macquarie segment (Fig. 3.1). Mid-ocean ridge spreading between ca. 40 and 6 Ma generated the oceanic crust of the Southeast Tasman and Emerald basins, found to the west and east of the MRC, respectively (Walcott, 1984). The past Australia-Pacific divergent plate boundary is herein referred to as the relic Macquarie spreading centre. Magmatism was confined to short spreading segments that were offset by long transform faults during oblique divergence from ca. 30 to 6 Ma (Massell et al., 2000). By 6 Ma relative plate motion along the boundary changed from divergence to dextral transpression (Mosher \& Massell-Symons, 2008). Strain is accommodated along the MRC by the active transform plate boundary (Fig. 3.1; Massell et al., 2000) and within the adjacent Macquarie Plate and Puysegur Block portions of the Australian Plate (Cande \& Stock, 2004; Hayes et al., 2009). This interplate and intraplate deformation has produced the asymptotically curved fracture zones adjacent to the MRC (Fig. 3.1 inset; Hayes et al., 2009). In addition to this, the Australian Plate is underthrusting the Pacific Plate at the Puysegur Trench between $46^{\circ} 00^{\prime} \mathrm{S}$ and $47^{\circ} 30^{\prime} \mathrm{S}$ (Lamarche et al., 2000) and at the Hjort Trench between $57^{\circ} 30^{\prime}$ S and 59 $30^{\prime}$ 'S (Meckel et al., 2003; Fig. 3.1).

Geochemical studies of MRC oceanic crust have been confined to Macquarie Island, which represents an uplifted ophiolite suite of crustal and mantle rocks (Griffin \& Varne, 1980). Macquarie Island crust has been dated at between 12 and 8 Ma with ${ }^{40} \mathrm{Ar}^{39} \mathrm{Ar}$ dating of basaltic samples (Duncan \& Varne, 1988) and biostratigraphic ages from microfossils in sediment between pillow lavas (Quilty et al., 2008). The volcanic rocks are predominantly enriched mid-ocean ridge basalt (E-MORB), which are inferred to have been derived from low degree partial melting as seafloor spreading rates slowed prior to the transition to transform relative plate motion (Kamenetsky et al., 2000; Varne et al., 2000). Conversely, the mantle rocks are highly refractory and therefore do not represent the melting residues of the 


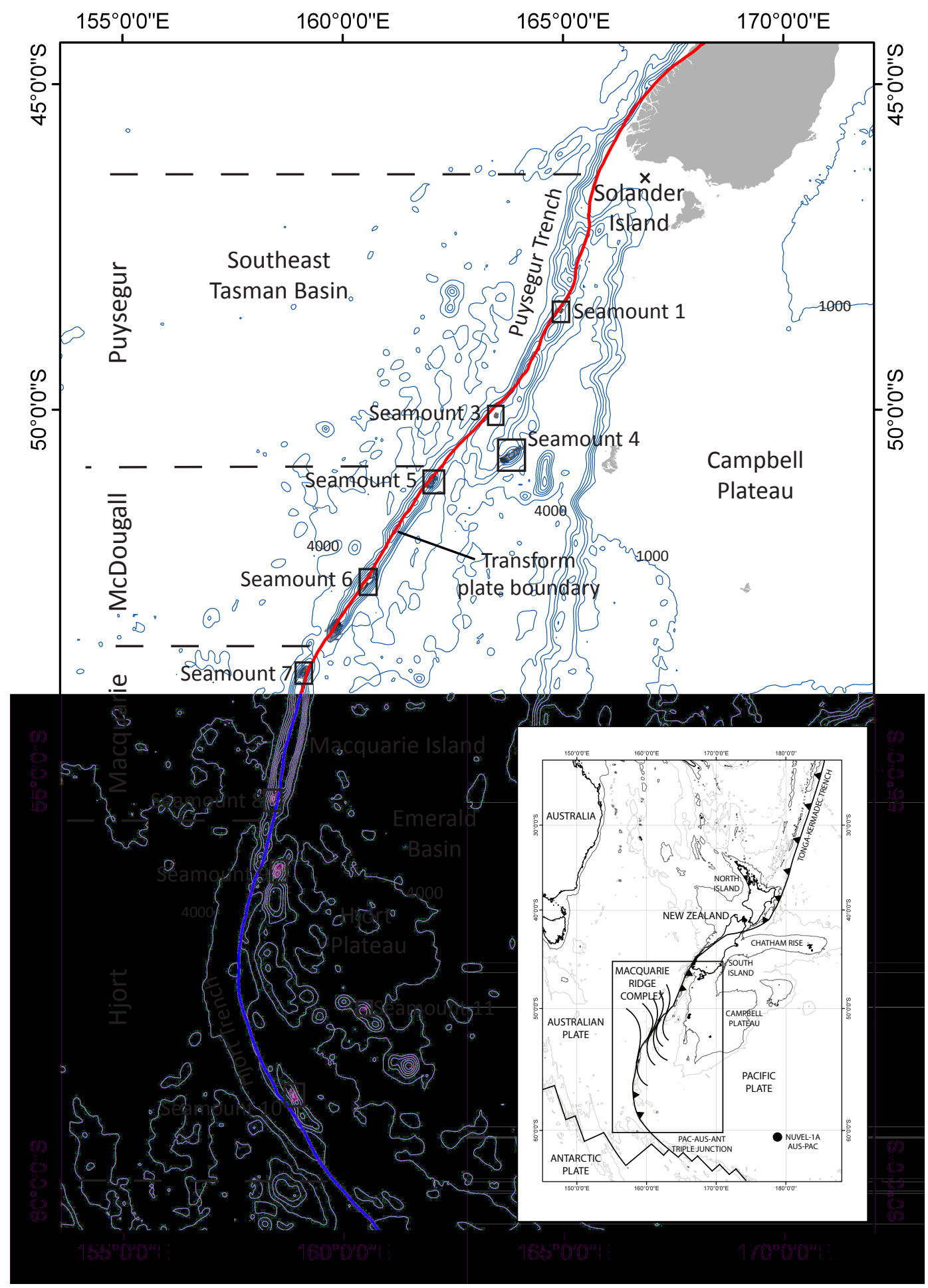

Figure 3.1. Bathymetric map of the Macquarie Ridge Complex and location of the 10 seamounts studied here (inset: position of the MRC relative to New Zealand and Australia). Isobaths shown for 1000, 1500, 2000, 2500, 3000 and 4000 m; 1000 and 4000 m isobaths are noted. The dextral transform plate boundary (red line) trends along the axis of the ridge. Black triangles indicate subduction of the Australian plate at the Puysegur and Hjort trenches (inset). Black circle represents the pole of relative Australia-Pacific plate motion (inset; DeMets et al., 1994). Thin black lines represent fracture zones that trend asymptotically into the plate boundary (inset). 
volcanic rocks (Dijkstra \& Cawood, 2004; Dijkstra et al., 2009). The only known subduction-related volcano along the Australia-Pacific plate boundary south of New Zealand is Solander Volcano, located ca. 100 km east of the Puysegur Trench (Fig. 3.1; Reay \& Parkinson, 1997), although several other submarine structures in the region have also been proposed to be volcanic features (Sutherland et al., 2006). The adakitic lavas exposed on Solander Island were erupted between 400 and 150 ka based on biotite ${ }^{40} \mathrm{Ar}-{ }^{39} \mathrm{Ar}$ ages (Mortimer et al., 2008).

\subsection{METHODS}

Data used in this study were collected during the TAN0803 voyage of March-April 2008 conducted by the National Institute of Water and Atmospheric Research (NIWA) on the RV Tangaroa. Ten seamounts along the MRC were selected for multibeam mapping, underwater-towed camera investigation and dredge sampling during the voyage. These seamounts are numbered 1 to 11 in this paper (investigation of seamount 2 was abandoned due to time constraints).

\subsubsection{Multibeam mapping}

Bathymetry and backscatter data were acquired simultaneously by the vessel's Kongsberg EM300 multibeam echosounder and initially processed on the RV Tangaroa using the program Hydromap. For this study, the backscatter data were processed using SonarScope using the procedure outlined by Lamarche et al. (2011). The backscatter data provide detailed information on the acoustic reflectivity associated with variations in the composition of the seafloor (Lamarche and Lebrun, 2000), ultimately enabling distinction between hard and soft substrates. While the bathymetric data were reprocessed in SonarScope as a necessary component of the backscatter processing, the original Hydromap bathymetry maps are used for qualitative analysis here. Assembled maps were imported into ArcGIS in order to characterize morphological and geological features of seamounts. 


\subsubsection{Underwater towed-camera images}

Photographic investigation of the MRC seafloor was achieved by deployment of NIWA's Deep-Towed Imaging System (DTIS) during voyage TAN0803. The DTIS consists of a high-resolution video camera and digital still camera mounted on a steel frame, which was lowered to the seafloor by a single core steel-armoured cable from the RV Tangaroa. Images from a total of 21 individual DTIS traverses across the 10 seamounts were classified. Lava flow morphology and type were classified according to the scheme outlined by Gregg and Fink (1995). Lava talus is used to describe coarse, angular material that has been abraded from lava flows. Volcaniclastic breccia is used to describe fragmental volcanic rocks that have glassy and rocky components. The term clastic refers to detrital material that cannot be unequivocally linked to provenance from a proximal volcanic source.

\subsubsection{Petrology and geochemistry analytical techniques}

\subsubsection{Sample acquisition and preparation}

Rock sampling was undertaken using an epibenthic sled at 7 of the 10 seamounts. A total of 37 dredge transects were undertaken during the voyage and 39 individual samples were prepared for petrological examination. From these, 9 volcanic glass and 20 whole rock samples were selected for chemical analyses. Volcanic glass occurring as rinds in pillow lava samples $(n=5)$ and grains in volcaniclastic breccia samples $(n=4)$ were crushed into $1-5 \mathrm{~mm}$-long fragments using an agate mortar and pestle. Fragments were subsequently washed in a beaker filled with Milli-Q water ( 4 times) and methanol ( 1 time) that was placed in an ultrasonic bath for 3 min at a time. Petrological features were examined by binocular microscopy and fresh, vitreous fragments were picked and mounted in epoxy resin for analysis. Whole rock samples were coarsely crushed (size $<20 \mathrm{~mm}$ ) and washed repetitively in boiling water to eliminate contamination from seawater. Whole rock samples were powdered using an agate swing mill at the University of Canterbury, New Zealand. 


\subsubsection{Major element analysis}

The nine glass samples were analysed at Victoria University of Wellington using a JEOL JXA-8230 SuperProbe electron probe micro-analyser (EPMA). KL2-G (basaltic glass, Hawaii) was used to calibrate major element oxides $\mathrm{SiO}_{2}, \mathrm{TiO}_{2}, \mathrm{Al}_{2} \mathrm{O}_{3}, \mathrm{FeO}$, $\mathrm{CaO}, \mathrm{MnO}, \mathrm{MgO}, \mathrm{K}_{2} \mathrm{O}, \mathrm{Na}_{2} \mathrm{O}$, while Beeson apatite $\left(\mathrm{P}_{2} \mathrm{O}_{5}\right)$ and a synthetic oxide $(\mathrm{MnO})$ were also used as primary standards. The EPMA was operated under the following settings: $15 \mathrm{kV}$ accelerating voltage, $8 \mathrm{nA}$ probe current, $20 \mu \mathrm{m}$ spot size and $30 \mathrm{~s} / 15 \mathrm{~s}$ peak/background counting times. Five spots on a homogeneous area of a single grain for pillow lava rind samples were acquired; 10 spots on each of at least 9 grains for individual breccia samples were analysed. Petrological features were examined by acquiring back-scattered electron (BSE) images of the glass grains using the EPMA. Whole rock major element analysis was carried out by SpectraChem Analytical, CRL Energy Ltd in Wellington, New Zealand. Rock sample (n $=20)$ and standard $(n=2)$ powders were prepared as fused metaborate glass disks and analysed by X-ray fluorescence spectrometry. Major element oxides were measured as weight percent based on $100^{\circ} \mathrm{C}$ oven-dried material.

\subsection{RESULTS}

This section describes (i) the morphology and (ii) substrate composition of MRC seamounts and (iii) the major element chemistry of dredge samples.

\subsubsection{Seamount morphology}

Bathymetry and backscatter maps of MRC seamounts are presented in Figure 3.2 and a summary of their morphological and geological features is presented in Table 3.1. Seamount summit depths range from $150-1,200 \mathrm{~m}$ below sea-level, and the surrounding flanks descend to water depths $>3,000 \mathrm{~m}$. Seamounts of the Puysegur and Hjort segments generally have deeper summits $(550-1,200 \mathrm{~m})$ than seamounts of the McDougall and Macquarie segments (150-800 m; Table 3.1). 


\begin{tabular}{|c|c|c|c|c|c|c|c|c|c|c|}
\hline 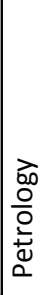 & $\frac{\mathbb{k}}{z}$ & 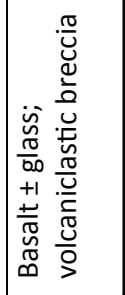 & $\frac{\varangle}{z}$ & 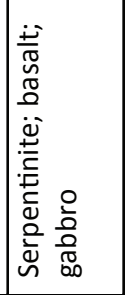 & 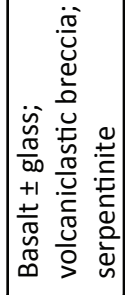 & 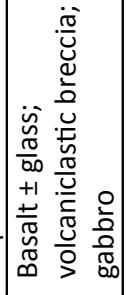 & 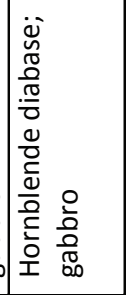 & 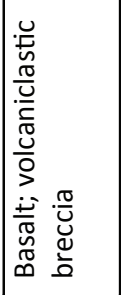 & 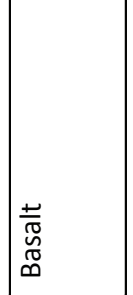 & $\frac{1}{z}$ \\
\hline 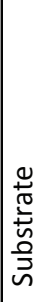 & 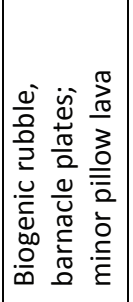 & 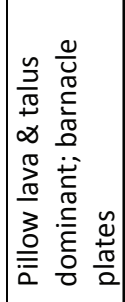 & 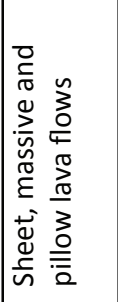 & 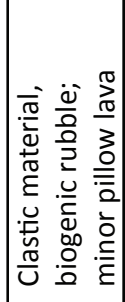 & 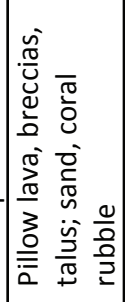 & 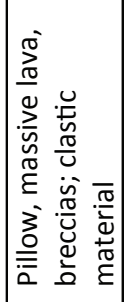 & 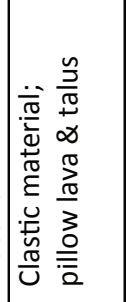 & 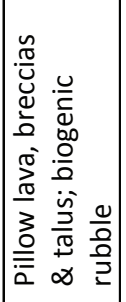 & 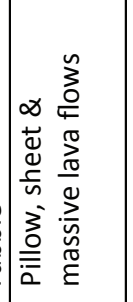 & 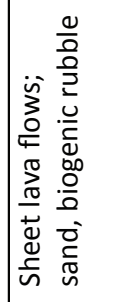 \\
\hline 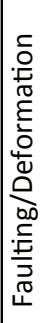 & 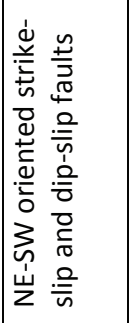 & 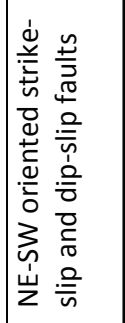 & 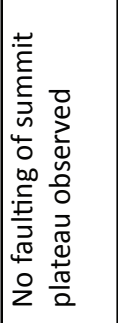 & 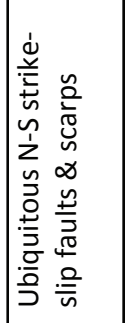 & 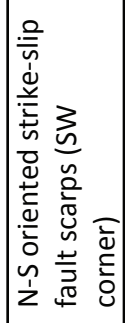 & 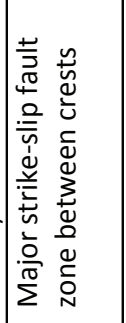 & 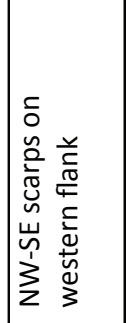 & 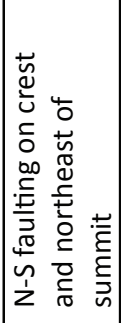 & 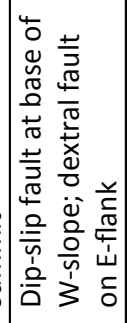 & 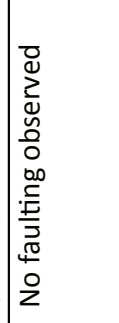 \\
\hline 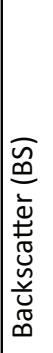 & 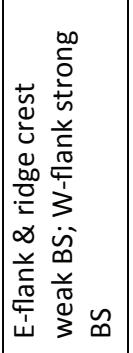 & 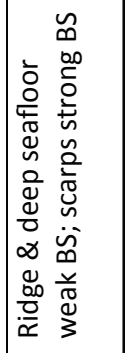 & 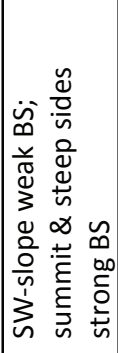 & 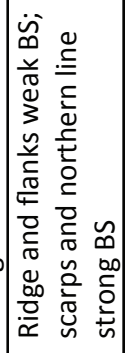 & 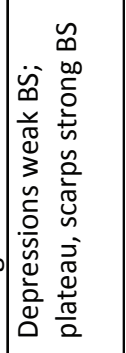 & 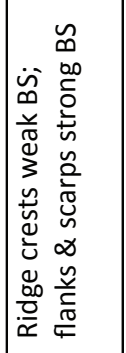 & 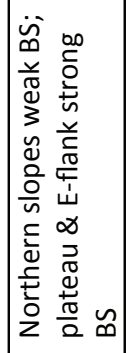 & 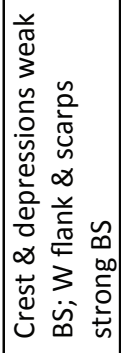 & 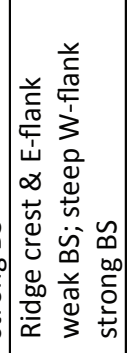 & 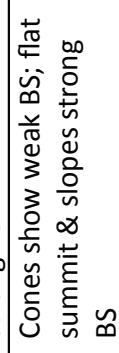 \\
\hline 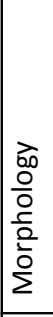 & 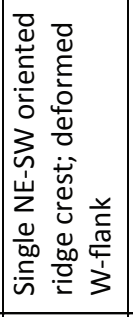 & 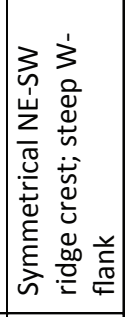 & 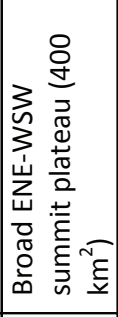 & 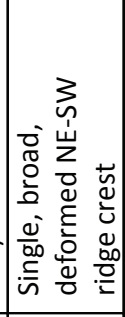 & 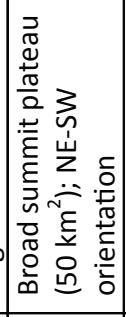 & 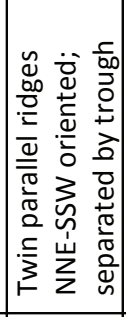 & 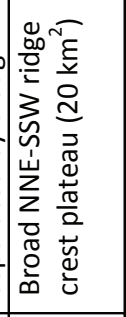 & 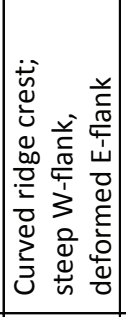 & 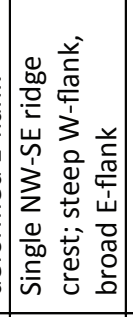 & 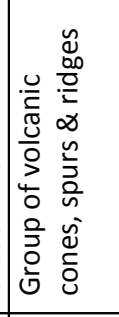 \\
\hline 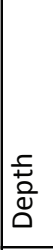 & 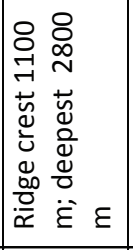 & 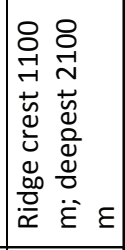 & 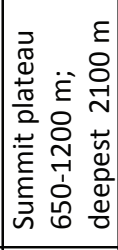 & 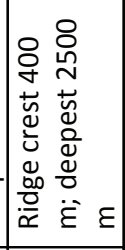 & 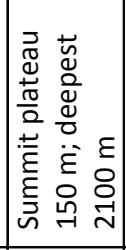 & 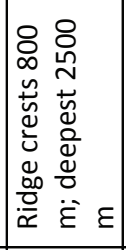 & 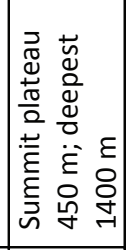 & 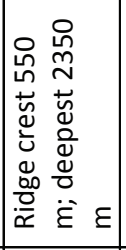 & 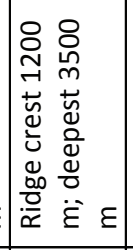 & 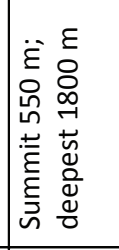 \\
\hline 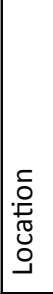 & 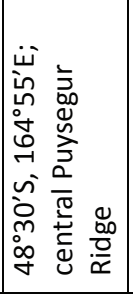 & 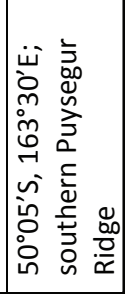 & 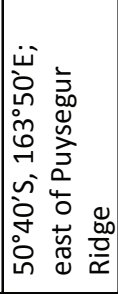 & 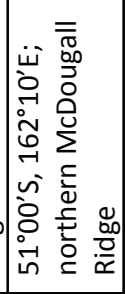 & 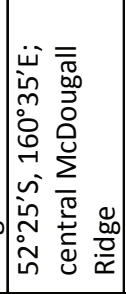 & 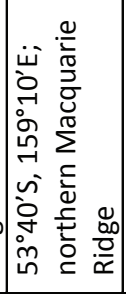 & 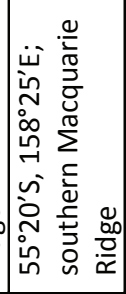 & 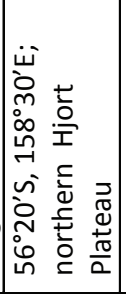 & 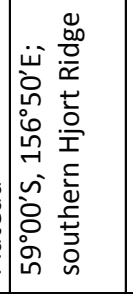 & 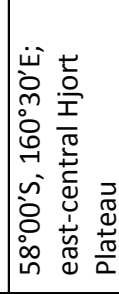 \\
\hline$\sum_{\text {葹 }}^{+}$ & & n & $\sigma$ & レ & & & & $1 \sigma$ & $\rightarrow$ & -1 \\
\hline
\end{tabular}




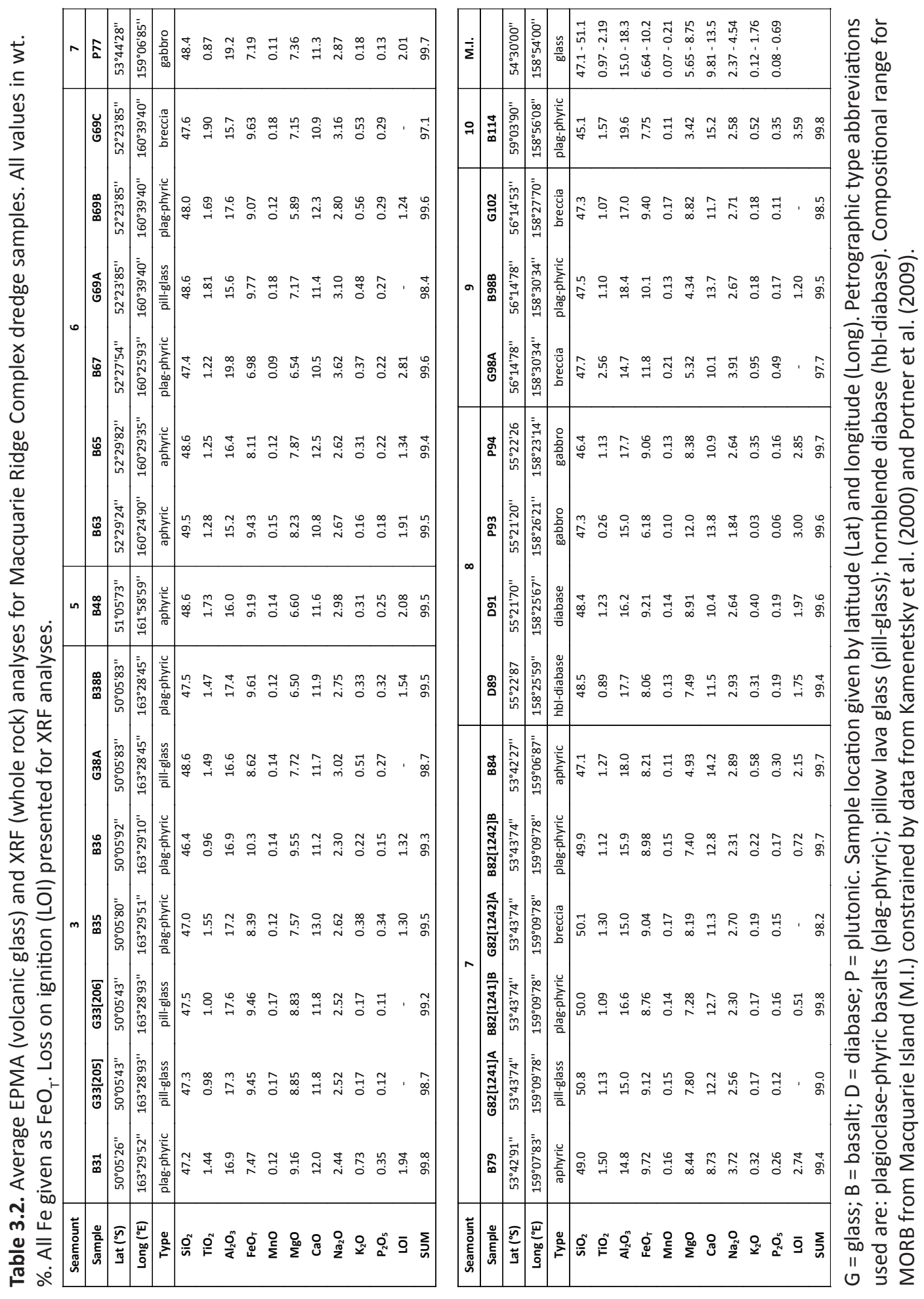


Seamounts located along the axis of the MRC are elongate structures that range in length from $5-40 \mathrm{~km}$ and are oriented parallel to the plate boundary. Seamounts 1, 3 and 10 are characterised by linear ridge crests that are bounded by dip-slip faults on their western flanks (Figs. 3.2.1, 3.2.2, 3.2.9). Seamount 5 is defined by a relatively broad summit region, flanked by a steep eastern slope and a deformed western slope characterised by numerous strike-slip fault scarps (Fig. 3.2.4). Seamount 7 comprises two parallel ridge crests, separated by a $<1,600 \mathrm{~m}$ deep trough and a zone of strike-slip faulting oriented NNE-SSW (Fig. 3.2.6). Seamount 9 has a curved crest, bounded by a very steep western scarp and gently sloping eastern flank. An area of deformation dominated by 4 major faults oriented $c a$. N-S is located northeast of the seamount summit (Fig. 3.2.7).

Seamounts 4, 6 and 8 are guyot-type seamounts that are characterised by flat-top summit plateaus. Seamount 4 is located east of the main axis of the MRC and defines a broad plateau that is oriented northeast-southwest (Fig. 3.2.3). The plateau covers an area of $c a .400 \mathrm{~km}^{2}$ and slopes from $650 \mathrm{~m}$ at its centre to 1,200 $\mathrm{m}$ at its edges, where it is bounded by steep scarps (Fig. 3.2.3). The morphology of seamount 6 is dominated by a summit plateau located at a water depth of $150 \mathrm{~m}$, oriented northeast-southwest, bordered by ca. $50 \mathrm{~m}$-high scarps and characterised by a right-angled northeastern corner (Fig. 3.2.4). Several scarps oriented ca. SE-NW are located on the eastern flank of the seamount; a zone of strike-slip faults is located west of the plateau (Fig. 3.2.4). Seamount 8 is characterised by an elongate summit plateau that is oriented NNE-SSW and bordered by scarp walls $<50 \mathrm{~m}$-high (Fig. 3.2.7). Several fault scarps are observed on the eastern flank (oriented NE-SW) and on the western flank (oriented NW-SE) and hummocky relief is ubiquitous on the southern and western flanks of the seamount (Fig. 3.2.7). Bifurcating ridges and cross-cutting furrows mark the summit plateau (Fig. 3.2.7). Seamount 11 is located east of the MRC on the Hjort Plateau and has a conical morphology with a broad summit peaking at $550 \mathrm{~m}$ water depth (Fig. 3.2.10). Several spurs and smaller cone structures are located on the flanks of the summit (Fig. 3.2.10). 

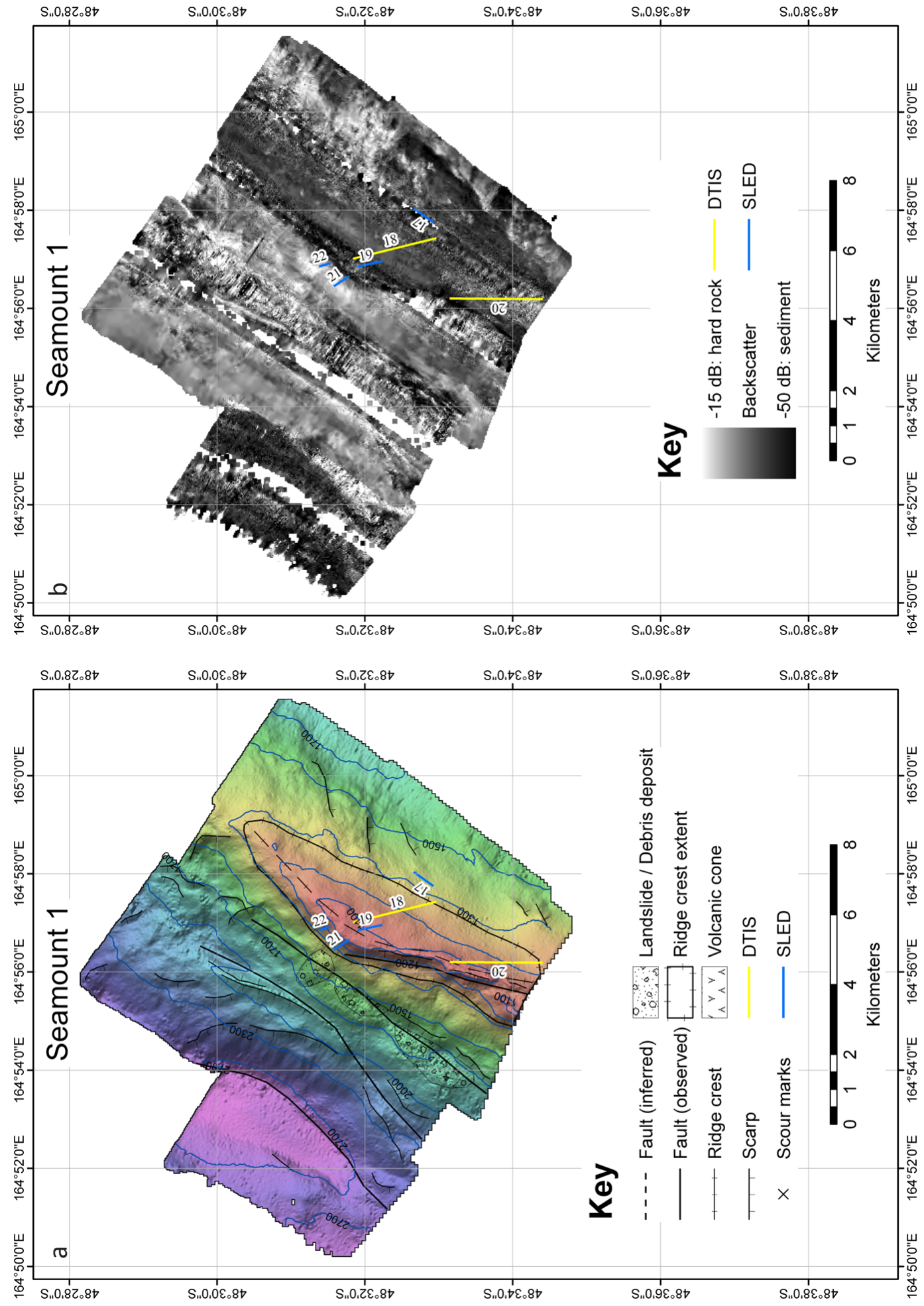

Figure 3.2.1. Bathymetry and backscatter maps for seamount 1 . Key displayed for seamount 1 applies to all seamounts. Numbers refer to stations for deep-towed imaging system (DTIS) and epibenthic dredge (SLED) traverses, which are shown by yellow and blue lines, respectively. 

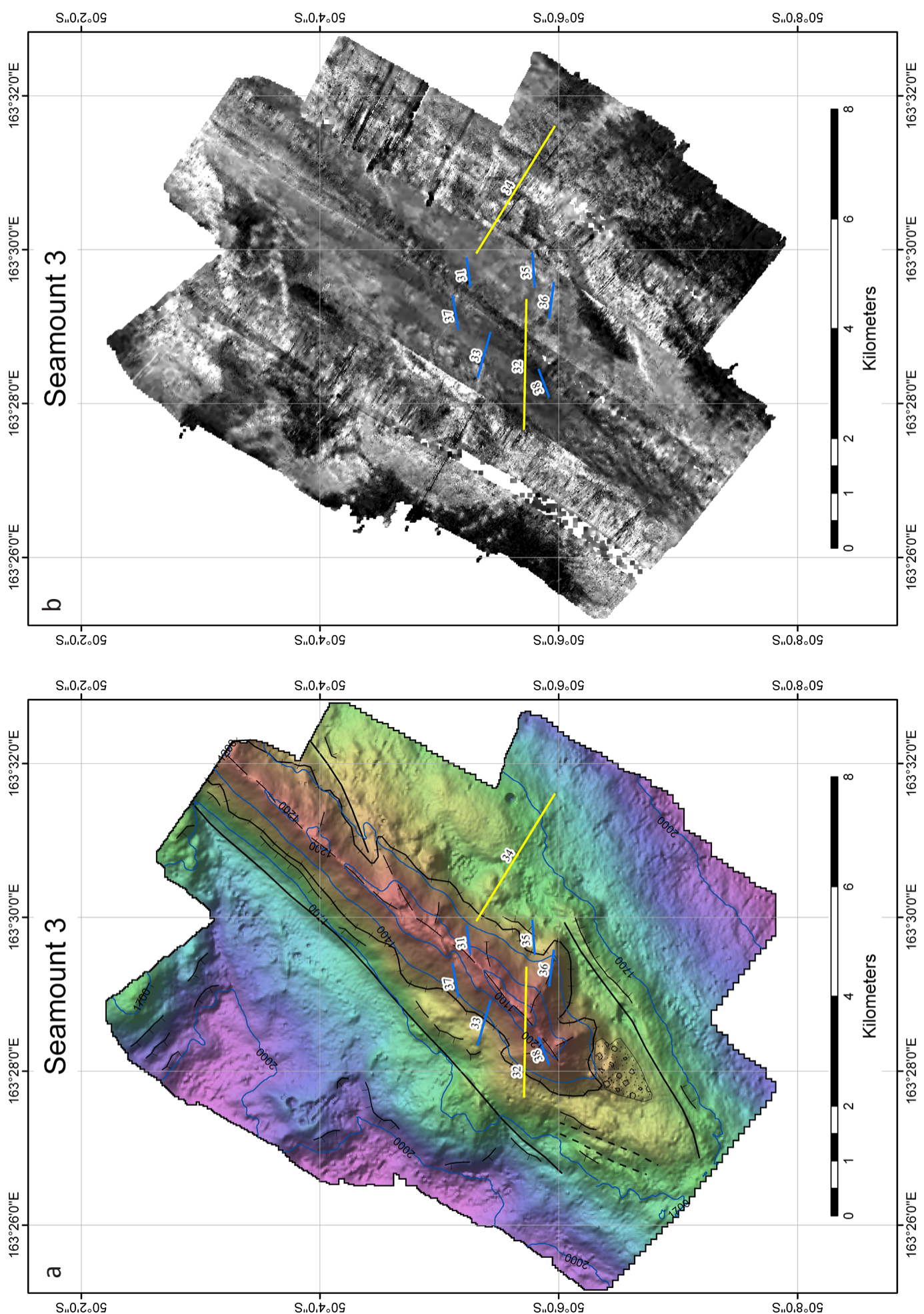

Figure 3.2.2. Bathymetry and backscatter maps for seamount 3. Key displayed for seamount 1 applies to all seamounts. Numbers refer to stations for deep-towed imaging system (DTIS) and epibenthic dredge (SLED) traverses, which are shown by yellow and blue lines, respectively. 

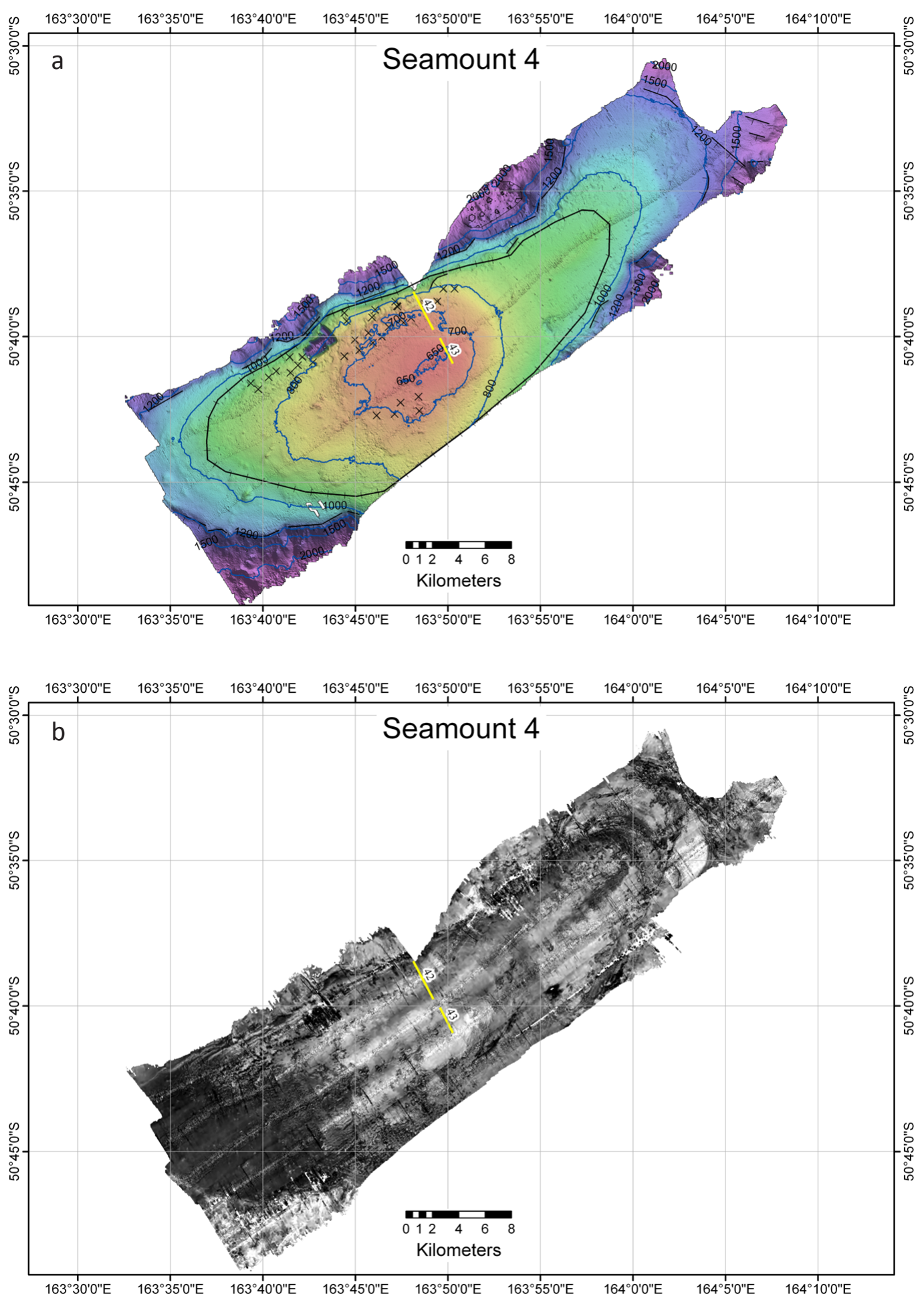

Figure 3.2.3. Bathymetry and backscatter maps for seamount 4. Key displayed for seamount 1 applies to all seamounts. Numbers refer to stations for deep-towed imaging system (DTIS) and epibenthic dredge (SLED) traverses, which are shown by yellow and blue lines, respectively. 

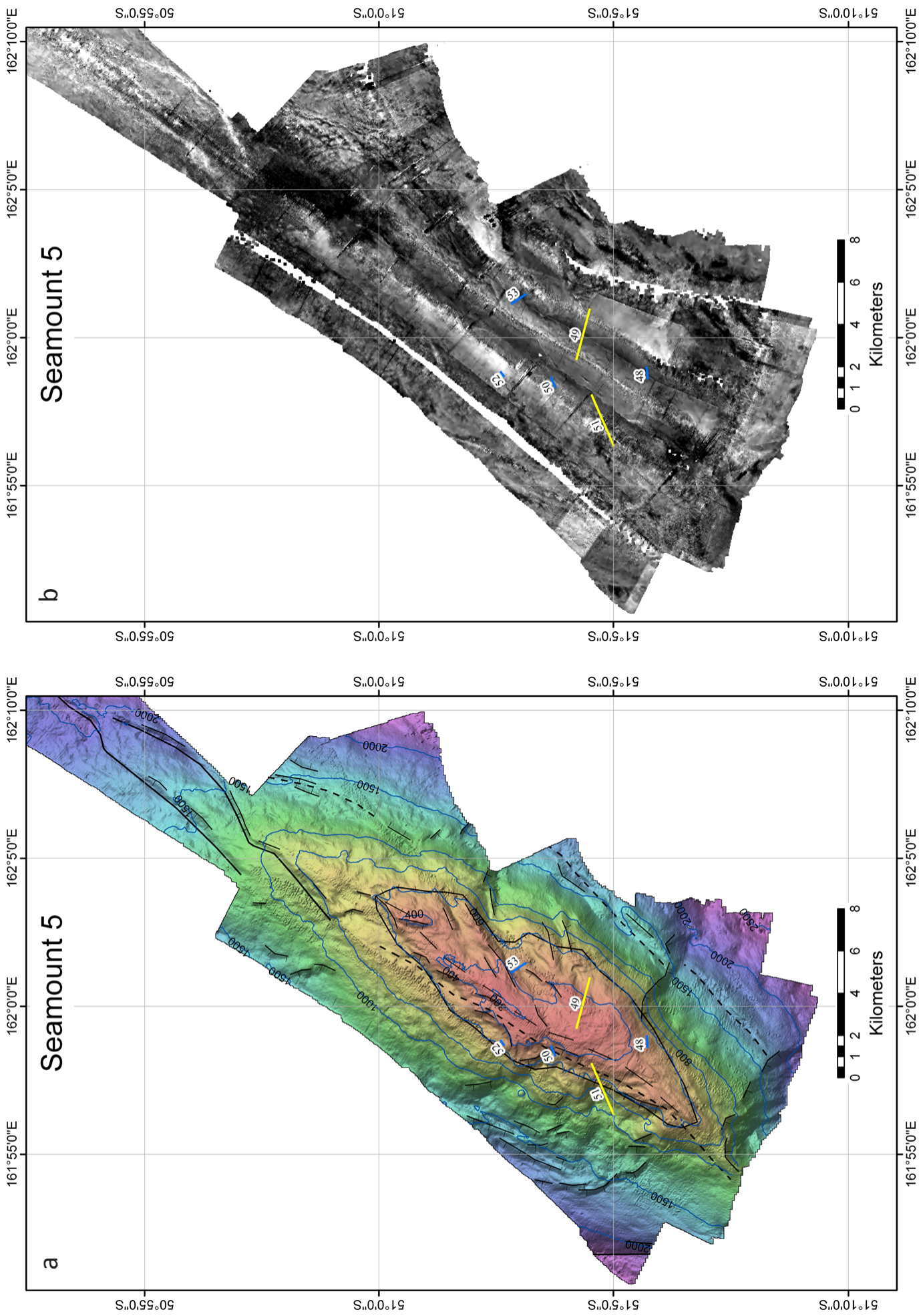

Figure 3.2.4. Bathymetry and backscatter maps for seamount 5 . Key displayed for seamount 1 applies to all seamounts. Numbers refer to stations for deep-towed imaging system (DTIS) and epibenthic dredge (SLED) traverses, which are shown by yellow and blue lines, respectively. 

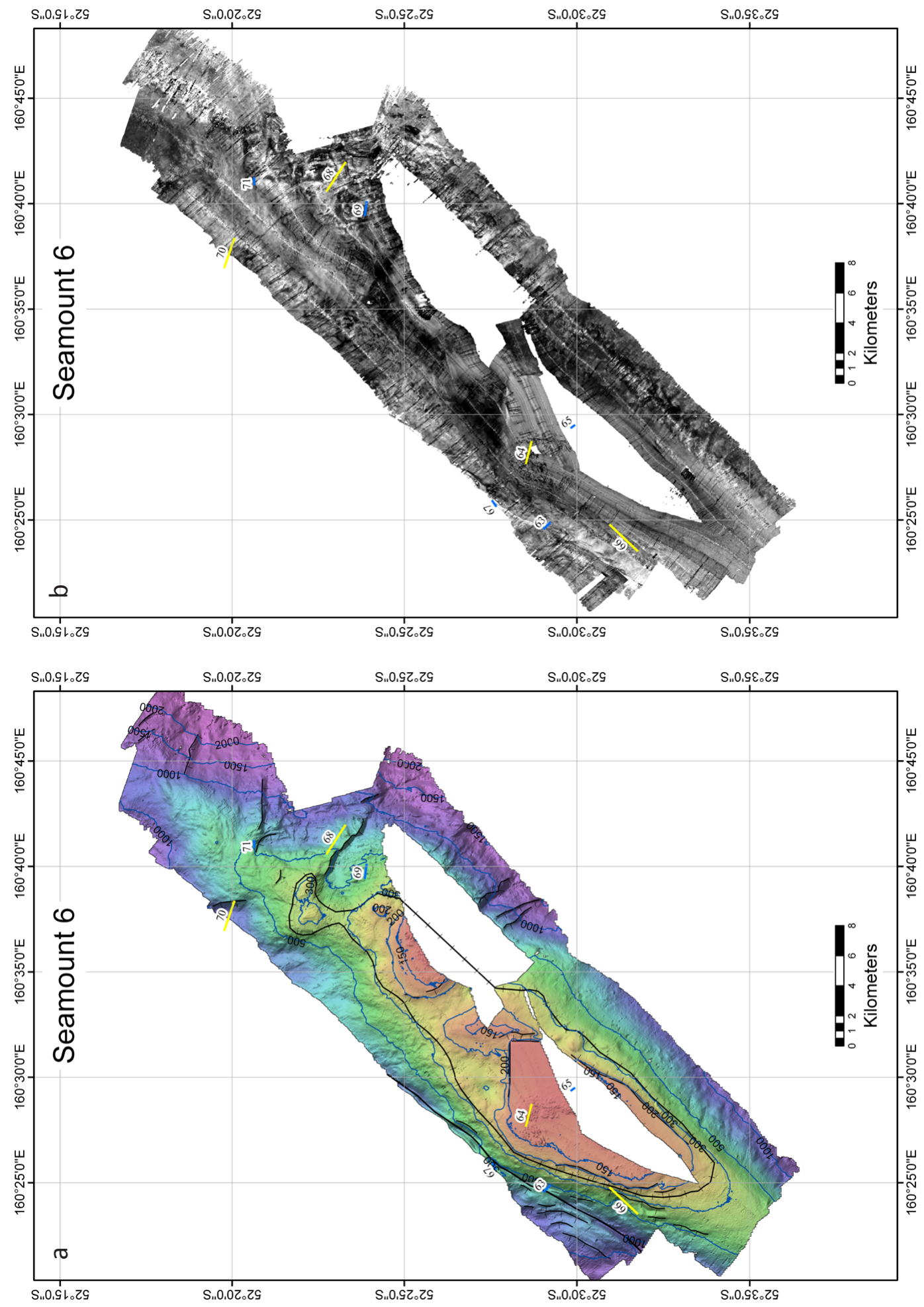

Figure 3.2.5. Bathymetry and backscatter maps for seamount 6 . Key displayed for seamount 1 applies to all seamounts. Numbers refer to stations for deep-towed imaging system (DTIS) and epibenthic dredge (SLED) traverses, which are shown by yellow and blue lines, respectively. 

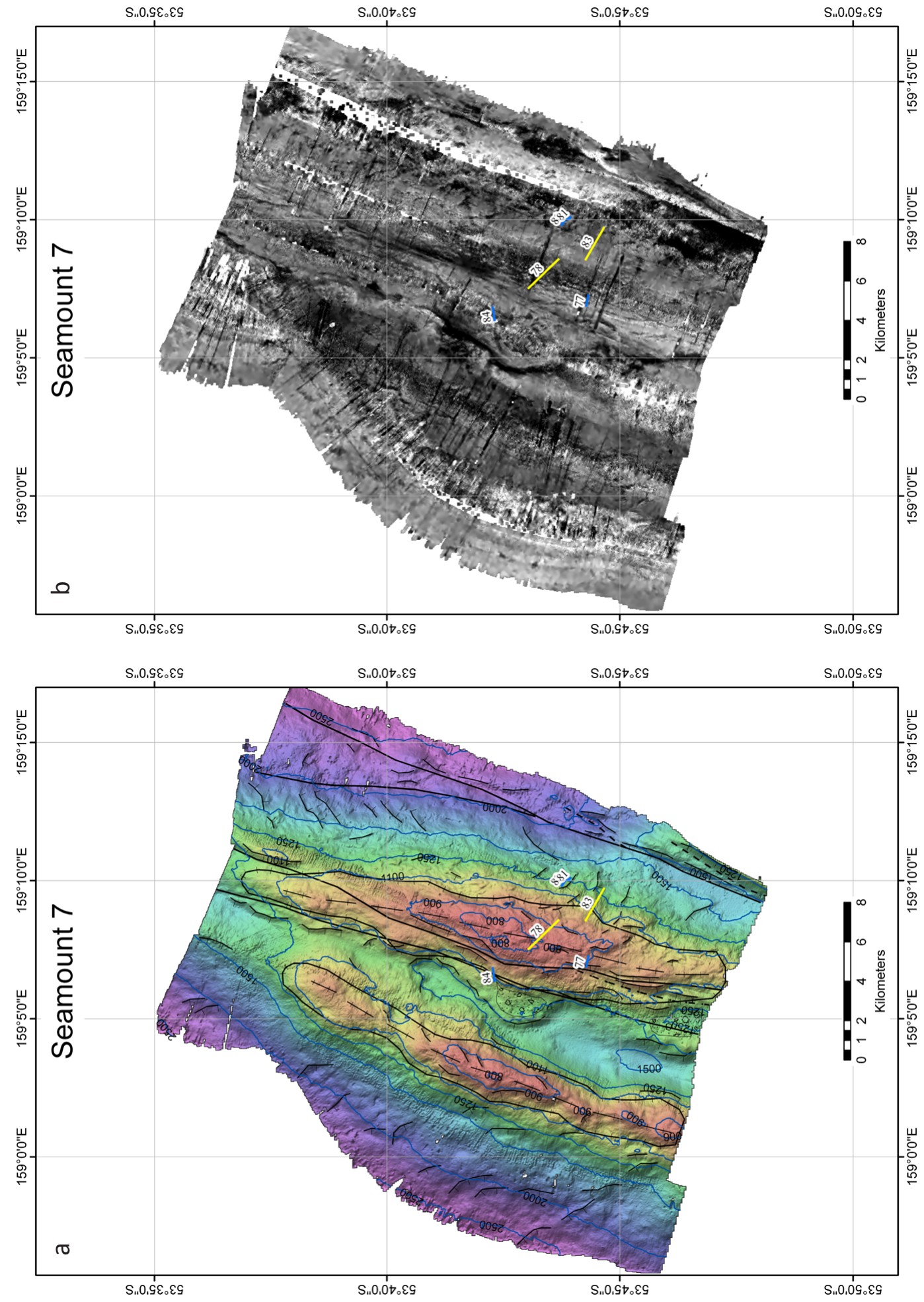

Figure 3.2.6. Bathymetry and backscatter maps for seamount 7. Key displayed for seamount 1 applies to all seamounts. Numbers refer to stations for deep-towed imaging system (DTIS) and epibenthic dredge (SLED) traverses, which are shown by yellow and blue lines, respectively. 

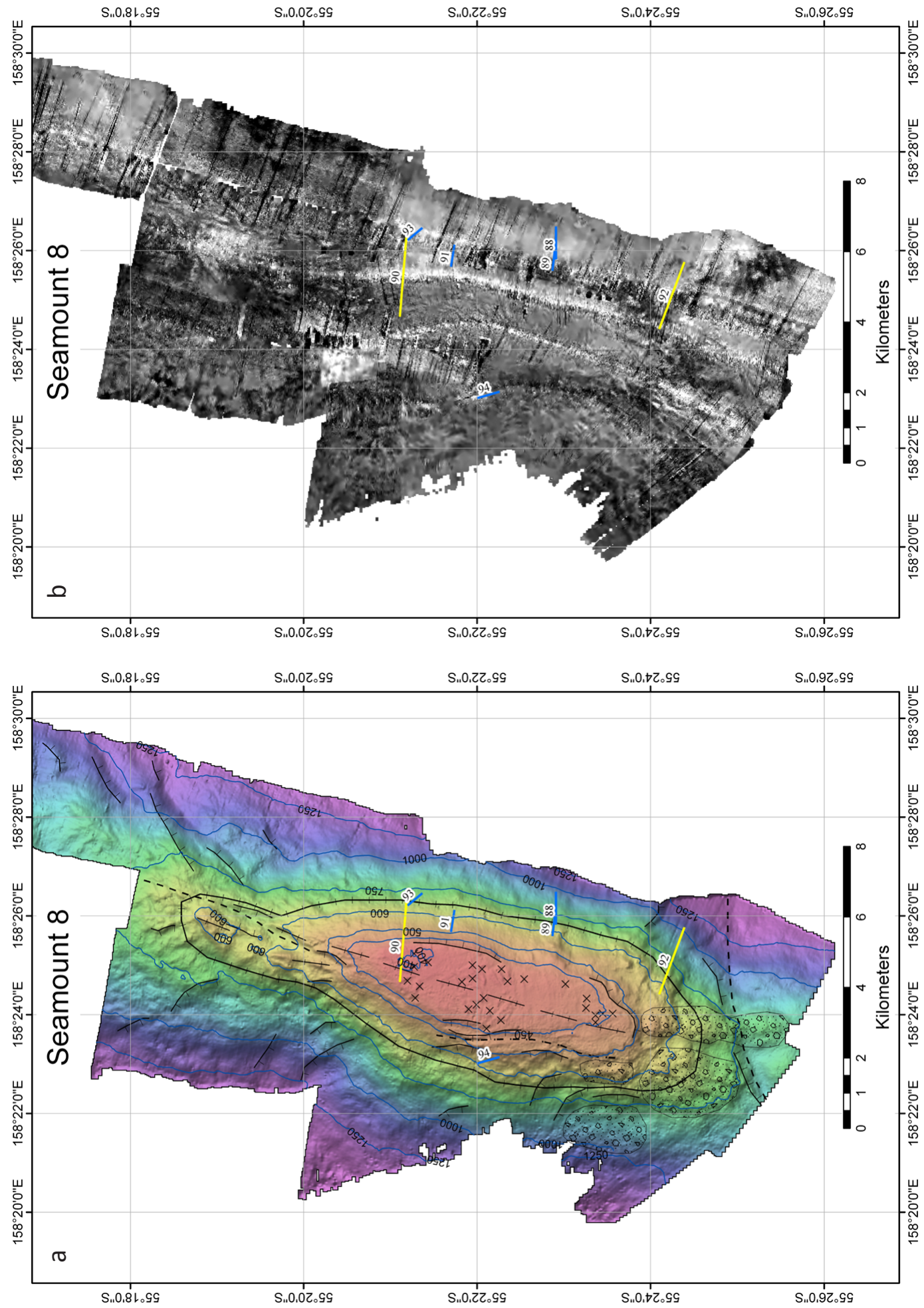

Figure 3.2.7. Bathymetry and backscatter maps for seamount 8. Key displayed for seamount 1 applies to all seamounts. Numbers refer to stations for deep-towed imaging system (DTIS) and epibenthic dredge (SLED) traverses, which are shown by yellow and blue lines, respectively. 

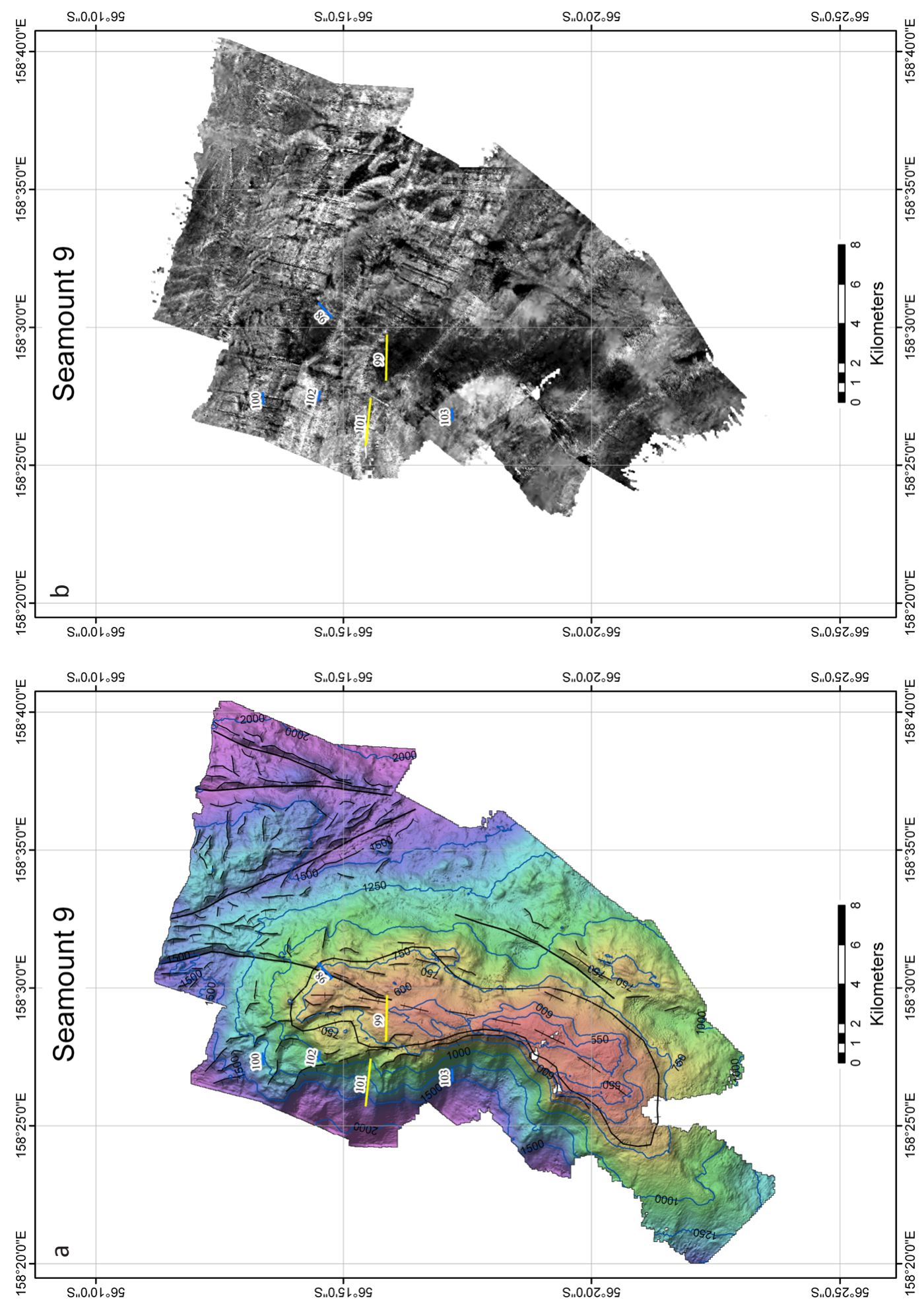

Figure 3.2.8. Bathymetry and backscatter maps for seamount 9. Key displayed for seamount 1 applies to all seamounts. Numbers refer to stations for deep-towed imaging system (DTIS) and epibenthic dredge (SLED) traverses, which are shown by yellow and blue lines, respectively. 

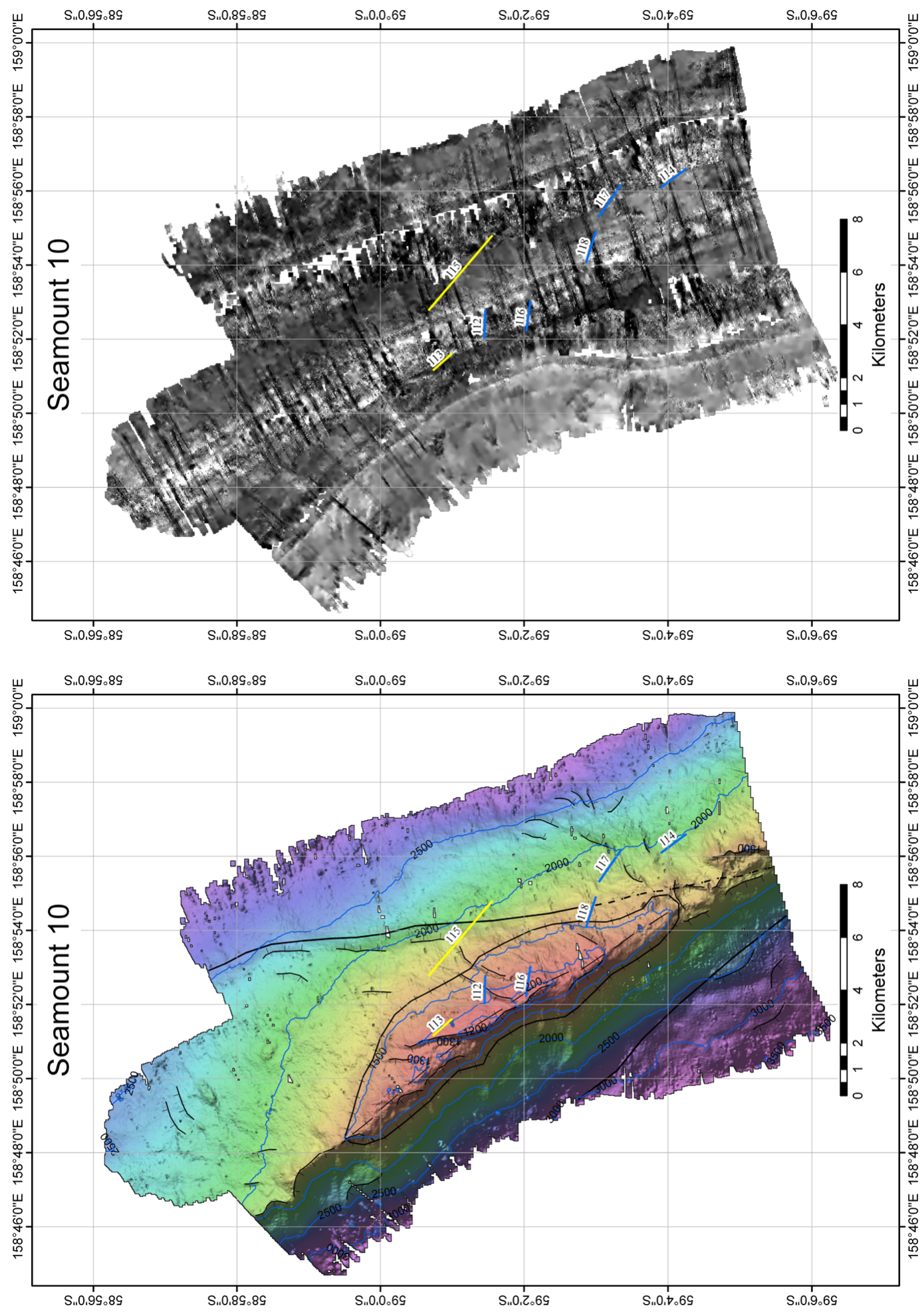

Figure 3.2.9. Bathymetry and backscatter maps for seamount 10. Key displayed for seamount 1 applies to all seamounts. Numbers refer to stations for deep-towed imaging system (DTIS) and epibenthic dredge (SLED) traverses, which are shown by yellow and blue lines, respectively. 

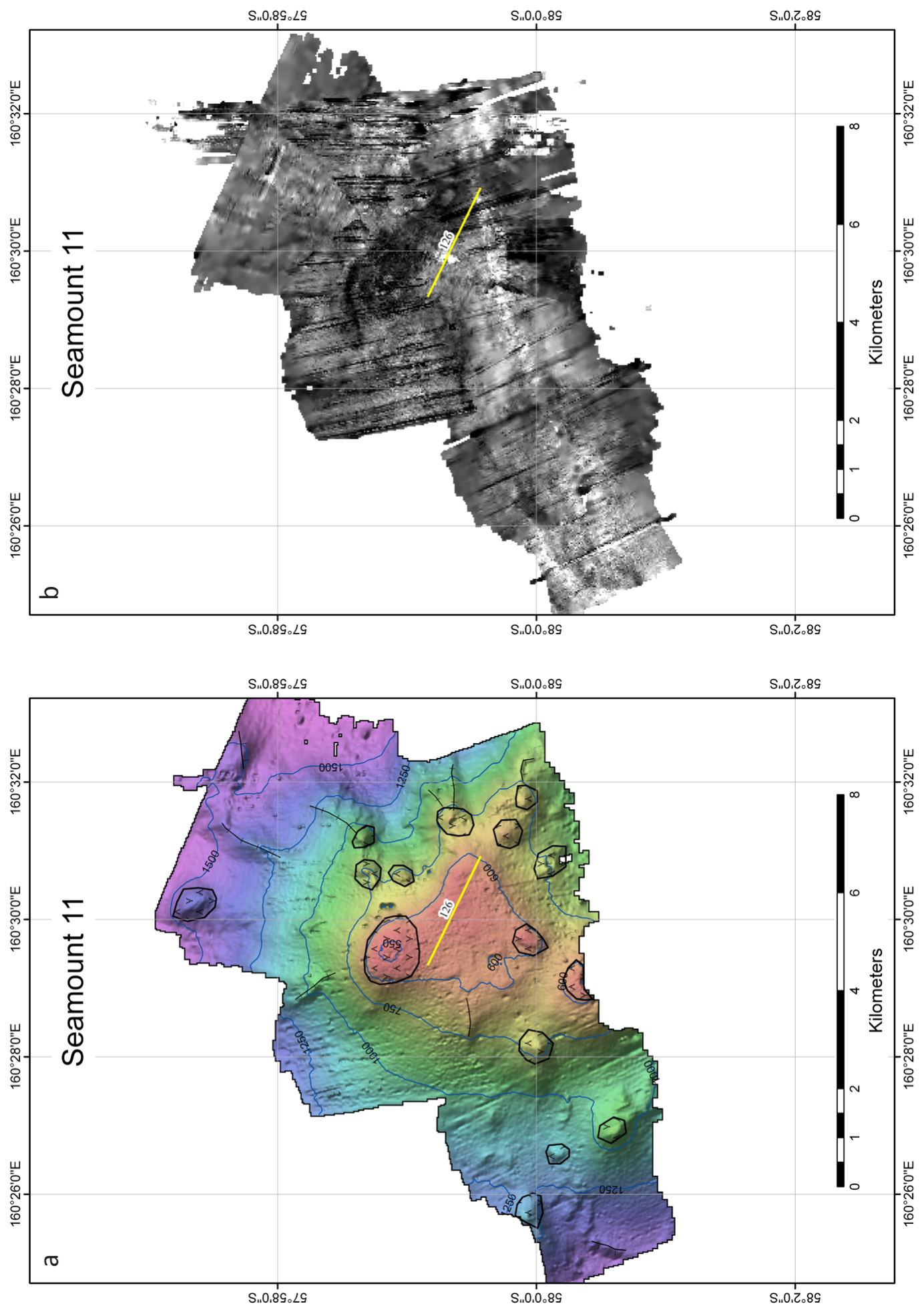

Figure 3.2.10. Bathymetry and backscatter maps for seamount 11 . Key displayed for seamount 1 applies to all seamounts. Numbers refer to stations for deep-towed imaging system (DTIS) and epibenthic dredge (SLED) traverses, which are shown by yellow and blue lines, respectively. 


\subsubsection{Substrate composition}

Photographic investigation and dredge sampling revealed that MRC seamounts are composed of a range of volcanic and biogenic substrates. Seamount 1 is composed of pillow lava flows, biogenic rubble and barnacle plates (Fig. 3.3a), the latter of which dominates the substrate composition of the ridge crest. No igneous rock samples were recovered from seamount 1 . DTIS traverses over the summit and eastern flank of seamount 3 revealed pillow lava flows and talus (Fig. 3.3b).

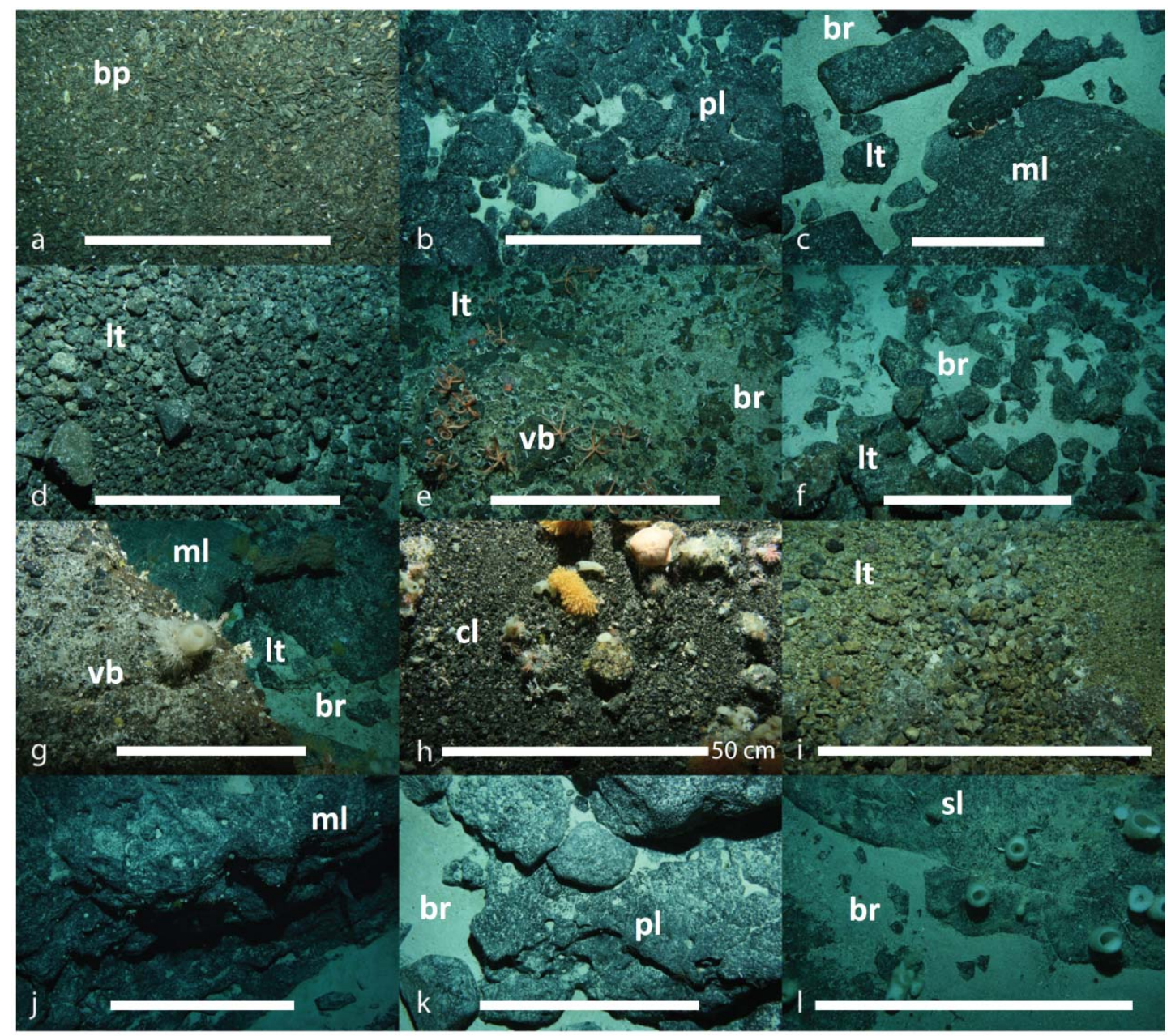

Figure 3.3. Images from DTIS investigation of MRC seamount substrates. Scale bar is $100 \mathrm{~cm}$ except where stated otherwise. (a) Barnacle plates (bp) cover the ridge crest substrate of seamount 1. (b) Pillow lava (pl) from seamount 3. (c) Massive lava (ml) and lava talus (lt) from the summit plateau of seamount 4. (d) Coarse angular lava talus (It) on seamount 5. (e) Pillowfragment volcaniclastic breccia (vb) and lava talus (lt) on seamount 6. (f) Lava talus (lt) and biogenic rubble (br) on seamount 6. (g) Volcaniclastic breccia (vb), massive lava (ml), lava talus (lt) and biogenic rubble (br) on seamount 7. (h) Well-sorted clastic material (cl) on seamount 8. (i) Coarse, angular lava talus (lt) on seamount 9. (j) Exposure of massive lava ( $\mathrm{ml}$ ) on seamount 10. (k) Pillow lava on seamount 10. (I) Sheet lava (sl) and biogenic rubble (br) on seamount 11. 
Rock samples dredged from seamount 3 are glassy lava, sparsely vesicular and plagioclase-phyric basalt and moderately vesicular basalt (Fig. 3.4a). Sheet and massive lava flows were observed on the western side of the summit plateau and pillow lava flows and talus were identified on the central summit area of seamount 4 (Fig. 3.3c). Seamount 4 is protected by the New Zealand Ministry of Fisheries and therefore no epibenthic sled samples were collected from this seamount.

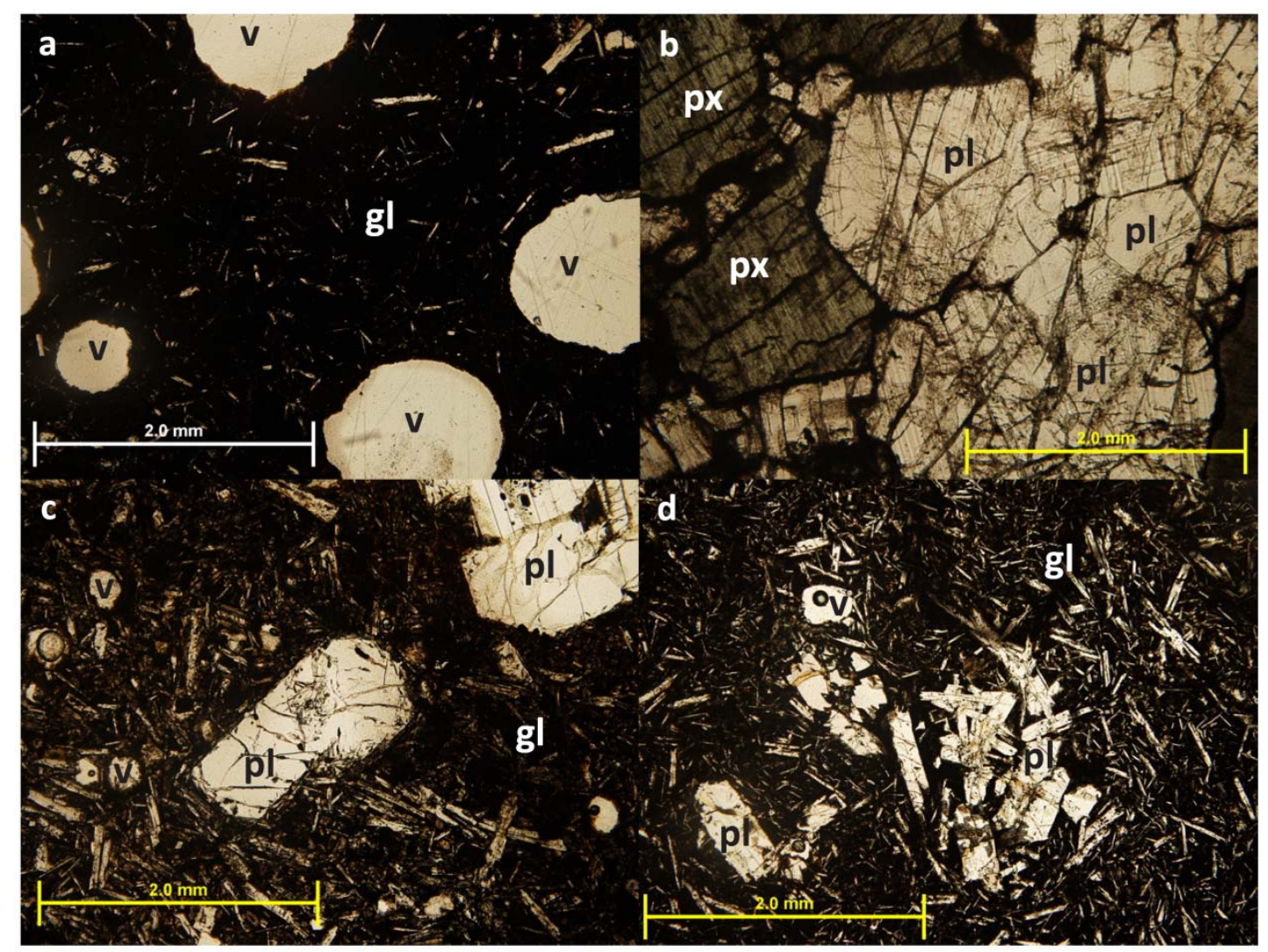

Figure 3.4. Representative photomicrographs (plane-polarized light) for MRC dredge samples. (a) moderately vesicular, non-porphyritic basalt sample 35 from seamount 3; (b) gabbro sample 53 from seamount 5; (c) plagioclase-phyric basalt 69B from seamount 6; (d) plagioclase-phyric basalt 98B from seamount 9 . Mineral type abbreviations are for glass ( $\mathrm{gl}$ ); vesicles (v); pyroxene (px); plagioclase (pl).

The summit of seamount 5 is comprised of clastic material, biogenic rubble and clusters of whole gastropod shells. Occasional lava exposures and deposits of wellsorted, cobble to boulder-sized, angular clasts (Fig. 3.3d) were observed on the western flank of seamount 5. Aphyric basalt, serpentinite and gabbro (Fig. 3.4b) samples were recovered from seamount 5. The summit plateau of seamount 6 is composed of biogenic rubble and sparse mounds of pillow lava flows, which are $<5$ m-high. The mounds coincide with a zone of irregular bathymetry on the summit 
plateau (Fig. 3.2.3). Clastic material and biogenic rubble were observed on the southwestern flank of the summit plateau. Glassy pillow lava, massive lava, volcaniclastic breccia (Fig. 3.3e) and lava talus (Fig. 3.3f) were observed on the northern flank of the seamount. Dredging at seamount 6 recovered glassy volcaniclastic breccia, plagioclase-phyric basalt (Fig. 3.4c), and aphyric basalt samples. The eastern ridge crest substrate of seamount 7 is comprised of pillow and massive lava flows and glassy volcaniclastic breccia (Fig. 3.3g). Substrate types observed on the eastern flank of the eastern ridge (DTIS traverse 083) include clastic material, barnacle plates and biogenic rubble. Dredging at seamount 7 recovered gabbro, glassy hyaloclastite breccia, plagioclase-phyric basalt and aphyric basalt samples. The substrate of seamount 8 is composed of rounded clastic material (Fig. 3.3h), biogenic rubble, pillow and massive lava flows and lava talus. Dredging at seamount 8 recovered diabase and gabbro samples; no volcanic lava samples were collected. The substrate of seamount 9 is composed of pillow lava and talus on the western flank and dominantly volcanic talus (Fig. 3.3i) on the summit. Volcaniclastic breccia and plagioclase-phyric basalt samples (Fig. 3.4d) were recovered from the northern flank of seamount 9 . The substrate of seamount 10 is composed of pillow, sheet and massive lava flows (Figs. 3.3j, 3.3k). One vesicular, plagioclase-phyric basalt was recovered from seamount 10 . The summit of seamount 11 is composed of sheet lava flows, lava talus and biogenic rubble (Fig. 3.3l). Seamount 11 is located within the Macquarie Island Marine Park, therefore no epibenthic sled samples were collected from this seamount. All volcanic lava dredge samples from MRC seamounts are non- to sparsely vesicular, except volcaniclastic breccia sample 98A, which is comprised of highly vesicular glass and lava clasts.

\subsubsection{Major element chemistry}

Dredge samples collected from MRC seamounts are alkaline to sub-alkaline basalts (Fig. 3.5), containing $45.1-50.8$ wt.\% $\mathrm{SiO}_{2}, 3.5-12.0$ wt.\% $\mathrm{MgO}$ and $1.9-4.9$ wt.\% total alkalis (Table 3.2). The shaded area of Figure 3.6 represents the compositional field for Macquarie Island defined by analyses of basaltic glass from a range of 
locations on the island by Kamenetsky et al. (2000) and Portner et al. (2009). The majority of samples from seamounts 3, 9 and 10 of the Puysegur and Hjort segments lie outside of this field (Fig. 3.5). Samples from seamounts 5, 6, 7 and 8 of the McDougall and Macquarie generally lie within the Macquarie Island compositional field (Fig. 3.5). The overall compositional ranges defined by Macquarie Island and dredge samples from MRC seamounts are broadly similar (Table 3.2).

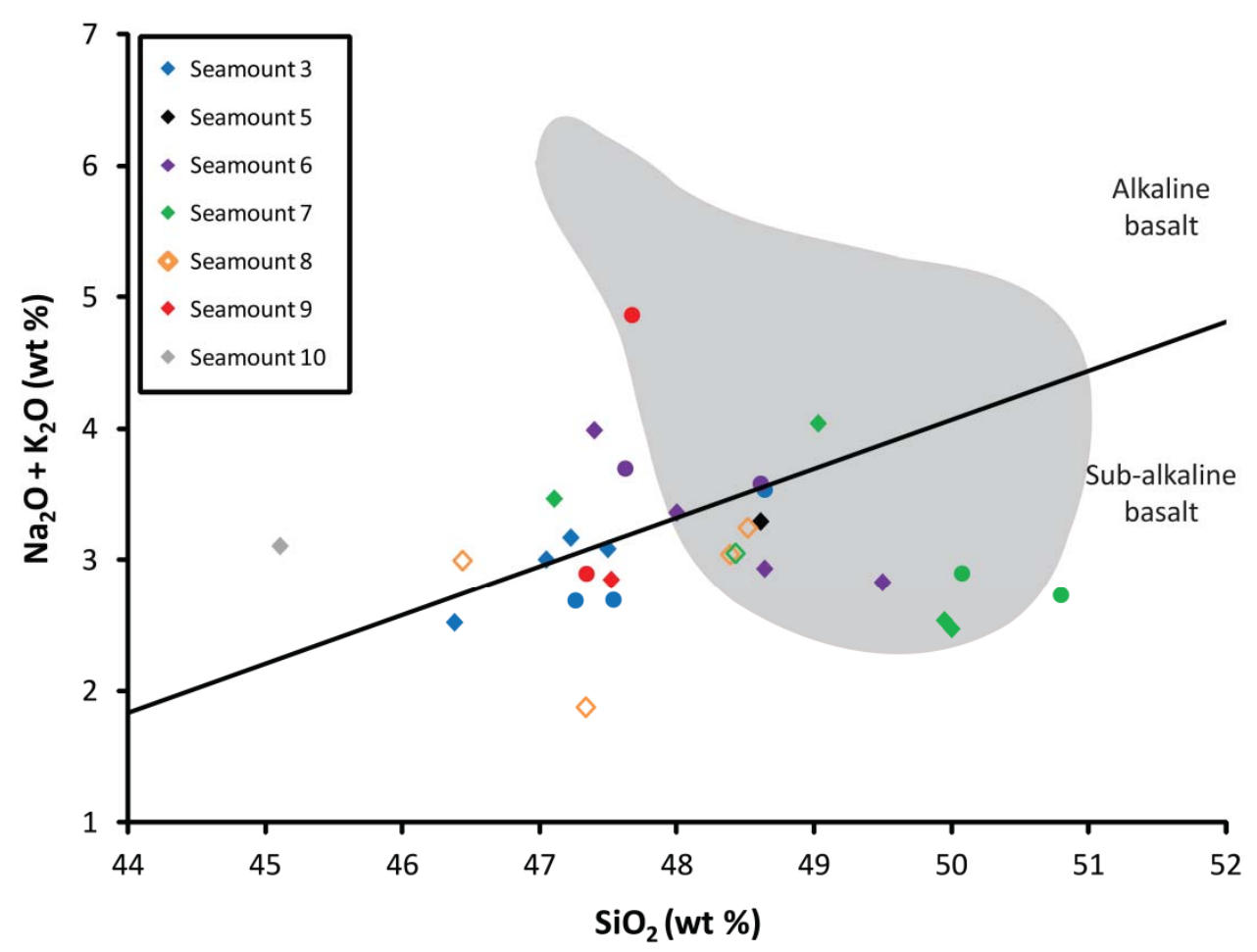

Figure 3.5. Total alkalis-silica classification diagram for MRC samples. Filled diamonds=whole rock volcanic samples; hollow diamonds=whole rock diabase and plutonic samples; circles=volcanic glass samples. Grey field denotes compositional range of Macquarie Island samples (data from Kamenetsky et al., 2000; Portner et al., 2009). Alkaline basalt field is from Macdonald \& Katsura (1964).

All MRC samples define values for $\mathrm{K} / \mathrm{Ti}>0.15$ and are thus classified as $\mathrm{E}-\mathrm{MORB}$ (Fig. 3.6). The major element composition of samples is plotted against the latitudinal location of samples along the roughly north-south orientation of the MRC in Figure 3.6. $\mathrm{SiO}_{2}$ content in MRC samples is highest at seamount 7 and decreases toward the north and south (Fig. 3.6). Considering the overall compositional range of all samples, individual seamounts define overlapping and relatively wide compositional ranges and there is no discernible relationship between the location of samples 
(and seamounts) and their major element composition. MgO contents vary from 3.4 to 12.0 wt.\%; sample P93 is the only sample with $\mathrm{MgO}>10$ wt.\% (Table 3.2). Given sample P93 is a cumulate plutonic rock, its bulk rock chemistry is not representative of a melt composition and is therefore not included in further discussion. Bivariate diagrams of major element contents versus MgO (Fig. 3.7) do not display any clear fractionation trends for sample suites from individual seamounts. Conversely, samples display ranges in $\mathrm{SiO}_{2}, \mathrm{Al}_{2} \mathrm{O}_{3}$ and $\mathrm{FeO}$ contents of up to 5 wt.\% at a given MgO content.
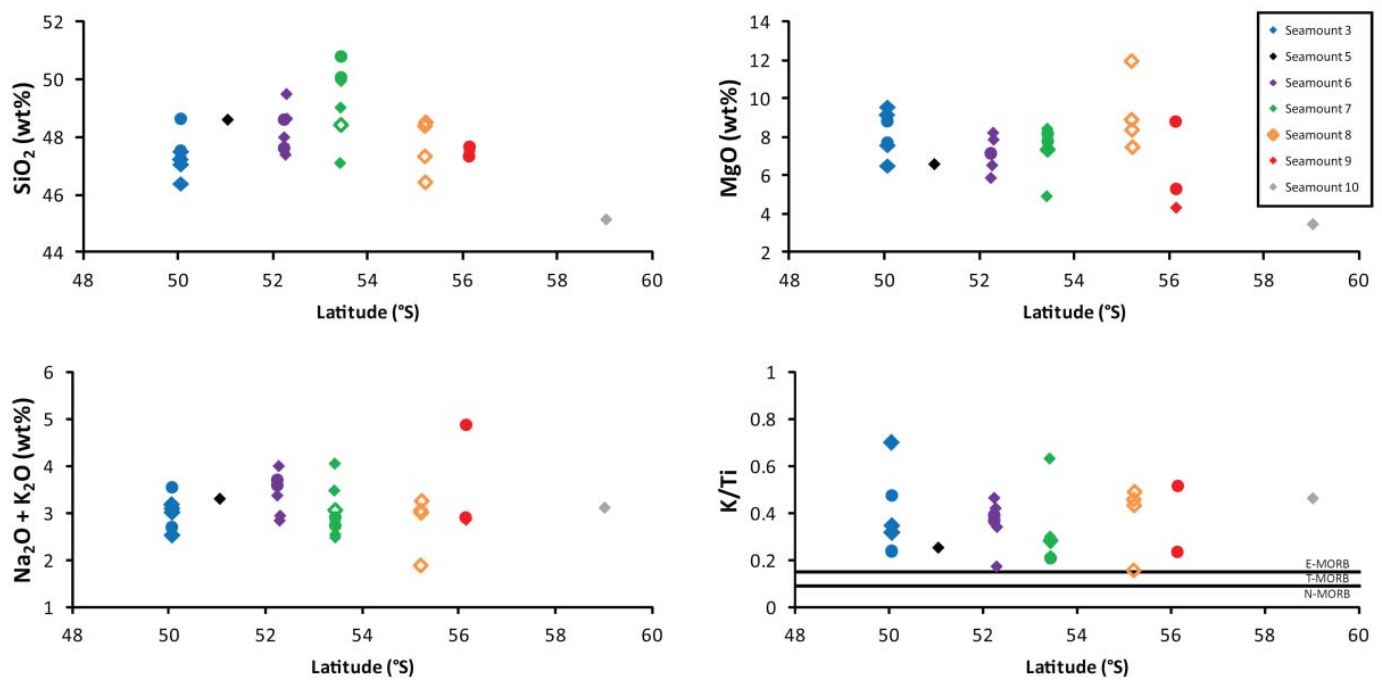

Figure 3.6. Major element content and $\mathrm{K} / \mathrm{Ti}$ versus latitude for $\mathrm{MRC}$ dredge samples. $\mathrm{MORB}$ fields: $\mathrm{N}-\mathrm{MORB}$ has $\mathrm{K} / \mathrm{Ti}<0.09$; T-MORB has $\mathrm{K} / \mathrm{Ti} 0.09$ to 0.15 ; $\mathrm{E}-\mathrm{MORB}$ has $\mathrm{K} / \mathrm{Ti}>0.15$ (Standish et al., 2008).

\subsection{DISCUSSION}

\subsection{Volcanism at the relic Macquarie spreading centre}

Divergent relative plate motion at mid-ocean ridges induces the ascent and adiabatic decompression melting of the sub-ridge asthenosphere (Bottinga et al., 1978). Mid-ocean ridge volcanoes are constructed in the axial rift zone of the divergent plate boundary as these melts are erupted as lava onto the seafloor (Macdonald, 1982). The Australia-Pacific plate boundary south of New Zealand was obliquely divergent with full-spreading rates of $<2 \mathrm{~cm} \mathrm{yr}^{-1}$ between $\mathrm{ca}$. 30-6 Ma (Wood et al., 1996; Mosher and Massell-Symons, 2008). Magnetic data indicate that the modern ridge is composed of oceanic crust with ages of $<30 \mathrm{Ma}$, which was formed during slow seafloor spreading (Cande \& Stock, 2004). Photographic 

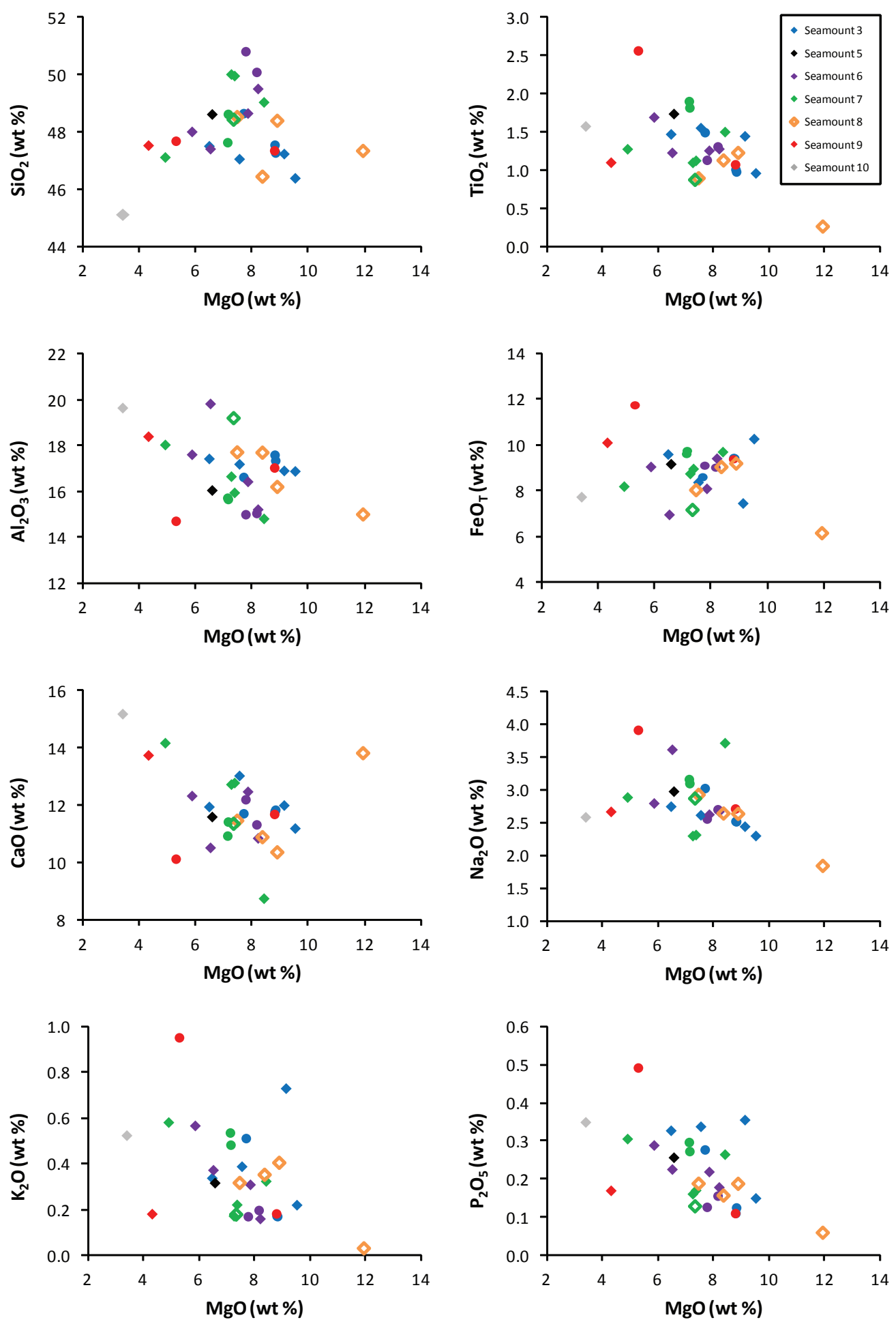

Figure 3.7. Bivariate MgO-major element diagrams for MRC dredge samples. 
investigation has revealed that pillow, massive and sheet lava flows, volcaniclastic breccia and volcanic talus compose the MRC seafloor (Table 3.1; Fig. 3.3). The observations are consistent with the types of oceanic crust exposed on Macquarie Island (Griffin \& Varne, 1980). DTIS images are corroborated by dredge samples from MRC seamounts, which include volcanic lava and breccia samples as well as serpentinite, diabase and gabbro (Table 3.1). Photographic and petrologic observation of non- to sparsely vesicular lava flows (Figs. $3.3,3,4$ ) is consistent with effusive volcanic eruption during slow and oblique seafloor spreading at the relic Macquarie spreading centre.

The major element composition of dredge samples from 7 seamounts along the MRC is broadly similar to MORB from Macquarie Island (Table 3.2; Fig. 3.5), although several samples exhibit significantly lower alkali element and $\mathrm{SiO}_{2}$ contents than volcanic rocks from the island (Fig. 3.5; Kamenetsky et al., 2000). Individual seamounts display wide compositional ranges (Fig. 3.6), which are defined by samples that are generally not related to each other by crystal fractionation (Fig. 3.7). $\mathrm{K} / \mathrm{Ti}$ values for MRC samples are comparable to E-MORB from the ultraslow spreading Southwest Indian Ridge (Standish et al., 2008) and Gakkel Ridge (Shaw et al., 2010), further supporting the theory that MRC dredge samples were derived from magmatism during slow seafloor spreading. Volcanism during oblique divergence at the plate boundary was confined to narrow spreading segments offset by long transform faults (Mosher \& Massell-Symons, 2008). Macquarie Island crust is suggested to have been generated in the vicinity of one of these segments between ca. 10-6 Ma (Mosher \& Massell-Symons, 2008). The prevalence of E-MORB compositions for samples from seamounts along 1,200 km of the MRC revealed in this study is a unique finding. The result indicates that volcanism driven by low degrees of partial melting was widespread during oblique divergence and/or the oceanic crust that comprises MRC seamounts was generated within narrow corridors of seafloor spreading, similar to Macquarie Island. The preservation of distinct magmatic batches over small areas at individual MRC seamounts and on Macquarie Island is the result of limited mixing of melts at the 
plate boundary during the waning stages of seafloor spreading (Daczko et al., 2009; Wertz, 2003).

Mid-ocean ridge magmatism during slow seafloor spreading at the relic Macquarie spreading centre is portrayed in Figure 3.8. Slow spreading rates induced low degrees of partial melting and inhibited mixing such that individual vents tapped discrete magma batches. Mid-ocean ridge volcanoes were comprised of pillow, sheet and massive lava flows and volcaniclastic breccias that were erupted effusively from these vents.

\subsubsection{Formation of MRC seamounts}

Plate boundary reconstructions indicate that oceanic crust created at the relic Macquarie spreading centre has been sheared and accreted along the boundary to form the MRC following the cessation of seafloor spreading (Mosher \& MassellSymons, 2008). Estimates of total brittle displacement across the plate boundary are $230-290 \mathrm{~km}$ since the transition to transpressional relative plate motion at $c a$. 6 Ma (Cande \& Stock, 2004). Dredge sampling of MRC seamounts reveals how oceanic crust has been transposed along the plate boundary. Sample suites from discrete segments of mid-ocean ridges often display systematic variations in major element contents over a range of MgO contents (e.g. Bender et al., 1978). Such relationships are explained by the eruption of basalts that have undergone variable degrees of fractional crystallization from a parental magma (Grove \& Bryan, 1983). Major element contents of MRC dredge samples do not display clear fractionation trends with MgO content (Fig. 3.7). Rather, samples from individual seamounts display differences of up to 5 wt.\% for $\mathrm{SiO}_{2}, \mathrm{FeO}$ and $\mathrm{Al}_{2} \mathrm{O}_{3}$ at a given $\mathrm{MgO}$ content (Fig. 3.7). Furthermore, the relatively wide and overlapping compositional ranges defined by samples from individual seamounts suggest that lavas were derived from numerous distinct magmatic sources (Figs. 3.6, 3.7). These geochemical trends indicate that lavas originating from spatially distinct magma chambers have been juxtaposed at seamounts by transpressional relative plate motion along the MRC (Fig. 3.8). This does not discount the theory that melts of distinct compositions were 
also erupted over small areas during slow seafloor spreading, as discussed above in Section 5.1.

The plate boundary-parallel orientation and elongate morphology of all present-day seamounts located on the ridge axis (Table 3.1; Fig. 3.1) is testament to the influence of transform deformation at the MRC. Strike-slip faults dominate the deformational structures of the seamounts (Table 3.1) and fault traces and scarps are ubiquitous. Seamounts 1,3 , and 10 are bounded by dip-slip faults on their western flanks; seamount 9 is bounded by a steep scarp on its western flank (Table 3.1; Figs. 3.2.1, 3.2.2, 3.2.8, 3.2.9). These seamounts are located on the Puysegur and Hjort ridge segments and the presence of dip-slip faulting is the result of greater boundary-normal relative plate motion here (Meckel et al., 2005). The greater summit depths of Puysegur and Hjort ridge seamounts compared to McDougall and Macquarie ridge seamounts (Table 3.1) may also indicate that subduction of the Australian plate at the Puysegur and Hjort trenches has pulled down the MRC on the overriding Pacific plate in these regions. It is evident from the relatively shallow seamount summit depth and sampling of plutonic rocks from the McDougall and Macquarie ridges that these segments of the MRC have also experienced substantial convergence, which has resulted in uplift and exhumation of MRC oceanic crust. The morphology of the MRC is controlled at the plate boundary scale by transpressional relative plate motion, which is partitioned into boundary-parallel transform faulting, and a convergent component that has created relief through flexural bulging of the crust (Daczko et al., 2003). MRC seamounts represent discrete bathymetric elevations created by strike-slip and dip-slip faulting of the ridge axis on a km-scale (Fig. 3.8). Morphological characteristics indicate that the seamounts are not remnant mid-ocean ridge volcanoes that have been preserved since the cessation of seafloor spreading at the Australia-Pacific plate boundary.

Lineaments and scarps trending ca. E-W on seamounts 5, 6 and 9 (Figs. 3.2.4, 3.2.5, 3.2.8) are interpreted to be related to relic faults and topography associated with past seafloor spreading (e. g. Massell et al., 2000; Meckel et al., 2003). Seamount 4 is located east of the main MRC and is interpreted to be a fault-bounded block 
based on the steep flanks on all sides of the seamount and its detachment and alternative orientation from the main ridge axis (Fig. 3.2.3). With the reorganization of the Australia-Pacific plate boundary from divergent to transverse motion, discrete portions of MRC oceanic crust (such as seamount 4) may have been displaced from the new ridge axis due to strike-slip deformation on existing transform faults.

\begin{tabular}{|l|l|} 
Description \\
\hline $\begin{array}{l}\text { Oblique divergence and slow seafloor } \\
\text { spreading rates } \\
\text { Low degrees of partial melting } \\
\text { Proximal vents tapped discrete magma } \\
\text { sources } \\
\text { Mid-ocean ridge volcanoes present } \\
\text { were comprised of effusively erupted } \\
\text { pillow (p), sheet (s) and massive (m) } \\
\text { lava flows and volcaniclastic breccias } \\
\text { (br) }\end{array}$ \\
\hline $\begin{array}{l}\text { Transform relative plate motion } \\
\text { Cessation of seafloor spreading and } \\
\text { mid-ocean ridge volcanism } \\
\text { Oceanic crust sheared by transform } \\
\text { deformation along MRC } \\
\text { Lava that was derived from distinct } \\
\text { magma sources juxtaposed due to } \\
\text { strike-slip faulting }\end{array}$
\end{tabular}

Figure 3.8. Schematic model for the evolution of MRC seamounts. Left column depicts a plan view of the plate boundary. Age constraints for relative plate motions (black arrows) based on Mosher and Massell-Symons (2008). Curved lines represent active (black) and extinct (grey) fracture zones. Black squares on plan view relate to position of cross-section through the ridge axis in the middle column. Different shades of grey reflect different magmatic sources of lava. Thin lines are strike-slip faults, or dip-slip faults where indicated with arrows.

In addition to past volcanic activity and ongoing tectonic deformation, our results reveal that the MRC has also been shaped by geomorphic processes. Well-sorted deposits of angular, boulder-sized clasts in DTIS images and hummocky relief on seamount flanks in bathymetry and backscatter maps are interpreted as evidence for mass wasting. Tectonic abrasion of MRC crust due to ubiquitous faulting of the 
ridge is likely to have produced these deposits (Fig. 3.8). Three of the 10 seamounts $(4,6,8)$ presented here have distinctive summit plateau morphologies. Many nearridge and intraplate seamounts have flat-topped, truncated cone morphologies (Clague et al., 2000). Processes attributed to causing these structures include lavapond volcanic construction from long-lived lava sources (Gulf of Alaska seamounts; Chaytor et al., 2007), lava-pond infilling of previously collapsed caldera structures (Northwest Pacific seamount chains; Clague et al., 2000) and volcanic eruption and construction from ring dikes (East Pacific Rise; Batiza \& Vanko, 1984). Alternatively, wave erosion of volcanoes with summits exposed above, or close to, sea-level can produce flat-topped seamounts (Paduan et al., 2009).

We interpret MRC seamounts 4, 6 and 8 to have been shaped by wave erosion during a relative lowering of sea-level via uplift of MRC oceanic crust, which was followed by subsequent subsidence. Observation of distinct erosional scarps that bound summit plateaux (seamounts 4, 6 and 8), well-sorted clastic substrates (seamount 8 and e.g. Paduan et al., 2009), sampling of plutonic rocks due to crustal exhumation (seamount 8) and the lack of volcanic or collapsed crater morphologies indicate that these flat-top seamounts were most likely formed by wave erosion and not volcanic processes. For the present-day summit depth of seamount 6, eustatic sea-level change during the last glacial maximum ca. $20 \mathrm{ka}$ (ca. $130 \mathrm{~m}$ lower than present sea-level; Clark \& Mix, 2002) can almost exclusively account for the required relative sea-level lowering. The irregular topography of the northwest corner of the plateau (Fig. 3.2.5) represents remnants of the seamount that were not eroded. The present-day plateau surface depths of seamounts $4(650 \mathrm{~m})$ and 8 $(450 \mathrm{~m})$ are not accessible to wave abrasion through Quaternary eustatic sea-level change. The seamounts are therefore suggested to have been eroded when their ridge sections were shallow enough to be affected by wave action, and have since subsided. Although transpressional motion operates along the plate boundary, seamounts 6 and 8 are proximal to the location of extensional pull-apart basins, which result from the en-echelon fault step-over pattern of the McDougall and Macquarie ridge segments by Daczko et al. (2003; their Figure 4). Mapping of recent faults on Macquarie Island has also revealed a dominance of high-angle normal 
faults that have created pull-apart basins (Daczko et al., 2003). Furthermore, Macquarie Island has been subsiding at a rate of $4.8 \mathrm{~mm} \mathrm{yr}^{-1}$ for the last $c a .80 \mathrm{yr}$ (Watson et al., 2010), in contrast to overall uplift at a rate of $0.8 \mathrm{~mm} \mathrm{yr}^{-1}$ over the last 340 kyr (Adamson et al., 1996). Thus, despite the relative convergence of the Australian and Pacific plates, it is possible that discrete portions of the MRC have experienced subsidence.

Ridges marking the summit plateau of seamount 8 are interpreted to be dykes that have been exposed due to the exhumation of volcanic rocks. This is consistent with the recovery of diabase and gabbro samples and no extrusive samples from the seamount (Table 3.1). The morphology of furrows on seamount 8 is consistent with features produced by iceberg scouring (e.g. Goff \& Austin, 2009). Icebergs rafted periodically from Antarctica have travelled east and north toward the Campbell Plateau over the past $200 \mathrm{kyr}$ (Carter et al., 2002). The MRC presents a major barrier to this route and interception of icebergs may have resulted in scouring of bathymetric highs such as seamount 8 . Summit erosion of seamounts 4,6 and 8 may also have been induced by ocean currents. The MRC forms a perpendicular barrier to the eastward flow of the Antarctic Circumpolar Current (ACC), which transports ca. $125 \times 10^{6} \mathrm{~m}^{3} \mathrm{~s}^{-1}$ of surface water and Circumpolar Deep Water south of Australia at a depth of $<2,500 \mathrm{~m}$ and traverses the ridge at a latitude of $c a .45^{\circ} \mathrm{S}$ (Schuur et al., 1998). Intensification of the ACC due to the presence of seamounts as discrete bathymetric elevations on the MRC may have resulted in erosion of their summits.

Notable similarities exist between MRC seamounts 6, 8 and Macquarie Island. Macquarie Island is elongate in shape (34 km-long and up to $5 \mathrm{~km}$-wide) and consists of an undulating plateau surface at $>200 \mathrm{~m}$ above sea-level, which is bounded by steep, $100 \mathrm{~m}$-high scarps with angles of $40-80^{\circ}$ (Selkirk et al., 1990). Knolls of pillow lavas, which are interpreted to represent little-altered submarine lava benches, are prominent in the topography of Macquarie Island (Selkirk et al., 1990). Seamounts 6 and 8 are elongate features ranging from ca. $10-25 \mathrm{~km}$ in length and $c a .5-10 \mathrm{~km}$ in width, which are characterised by broad summit plateaux that are bounded by steep, 50 m-high scarps (Figs. 3.2.3, 3.2.4). The knolls 
on Macquarie Island may be equivalent to the pillow lava mounds identified on the summit plateau of seamount 6 (Fig. 3.2.5). Similar to MRC seamounts, E-MORB compositions are pervasive and geochemically distinct magma batches are preserved over small areas on Macquarie Island (Daczko et al., 2009). The morphological and geochemical similarities between MRC seamounts and Macquarie Island suggest a common formational history. The defining distinction between the two features is that Macquarie Island has been uplifted above sealevel. Subsidence of Macquarie Island (presently occurring at $4.8 \mathrm{~mm} \mathrm{yr}^{-1}$; Watson et al., 2010) may eventuate in the submersion of the island, however, and result in its conversion to a guyot-type seamount. MRC seamounts 6 and 8 may represent features that have experienced the final stage of such an evolutionary pathway. Alternatively, they are parts of the ridge that were never completely uplifted above sea-level.

Seamounts distal from the ridge axis of the MRC are not subjected to plate boundary deformation and exhibit typical volcanic morphologies. This is the case for seamount 11, which resembles an eroded volcanic cone (Fig. 3.2.10). Located on the central Hjort Plateau, at a distance of ca. $200 \mathrm{~km}$ east of the Hjort Trench (Fig. 3.1), it is unlikely that seamount 11 (as well as several other volcanoes surrounding it; see Meckel et al., 2003) is related to subduction of the Australian Plate at the incipient subduction zone. Rather, a fracture zone or intraplate volcanic origin is more likely (Meckel et al., 2003). Due to the sampling restriction imposed for this seamount, it was not possible to determine the origin through geochemistry. Nevertheless, seamount 11 is a volcanic seamount, as opposed to the tectonicallygenerated seamounts located along the axis of the MRC. Solander Island is the only known volcano related to subduction of the Australian Plate south of New Zealand (Reay \& Parkinson, 1997). Two seamount structures located northwest of Solander Island have also been suggested to represent volcanic intrusions related to subduction at the Puysegur Trench (Sutherland et al., 2006). However, bathymetric mapping and dredging during a recent RV Tangaroa voyage in April 2011 (TAN1106) indicates that the seamounts are fault-bounded blocks of continental crust (Bostock, 2011). 


\section{CONCLUSIONS}

Mid-ocean ridge volcanism at the relic Macquarie spreading centre involved the eruption of sub-alkaline to alkaline E-MORB generated by low degrees of partial melting associated with slow seafloor spreading rates. The pervasive E-MORB signature among MRC samples indicates that volcanism was widespread along the plate boundary during oblique divergence and/or that crust that comprises MRC seamounts was generated within narrow corridors of seafloor spreading. Effusively erupted pillow, sheet and massive lava flows, and volcaniclastic breccias formed mid-ocean ridge volcanoes during relative plate divergence. Lavas were erupted from proximal vents that tapped distinct magmatic sources due to limited mixing of melts as a result of low magmatic activity during the late stages of seafloor spreading. Oceanic crust has been sheared, accreted and exhumed along the Australia-Pacific plate boundary south of New Zealand and comprises the substrate of the MRC. Transform faulting has juxtaposed lavas that were derived from discrete magma chambers at individual seamount locations. Seamounts are aligned parallel to the plate boundary and elevated above the surrounding seafloor of the MRC as a result of discrete strike-slip and dip-slip faulting of the ridge axis. Seamounts on the Puysegur and Hjort ridges are bounded by western dip-slip faults, reflecting the greater boundary-normal relative plate motion that these segments of the MRC experience compared to the McDougall and Macquarie segments. Three guyot-type seamounts $(4,6,8)$ located on the McDougall and Macquarie ridge segments have broad plateaux that were formed by wave (and current) erosion when their summits were at or near sea-level due to uplift of the ridge. Subsequent subsidence due to extension associated with the step-over fault pattern of the transform plate boundary is inferred to account for the present depth of the summits. Morphological and geochemical similarities between MRC seamounts and Macquarie Island suggest that the features share a common formational history. Seamounts distal from the Australia-Pacific plate boundary are not subjected to tectonic deformation and retain original volcanic morphologies. MRC seamounts are products of the interplay between volcanic, tectonic and geomorphic processes at an active plate boundary. 


\section{CHAPTER 4:}

\section{PETROLOGY AND GEOCHEMISTRY OF VOLCANIC GLASS FROM THE MACQUARIE RIDGE COMPLEX}

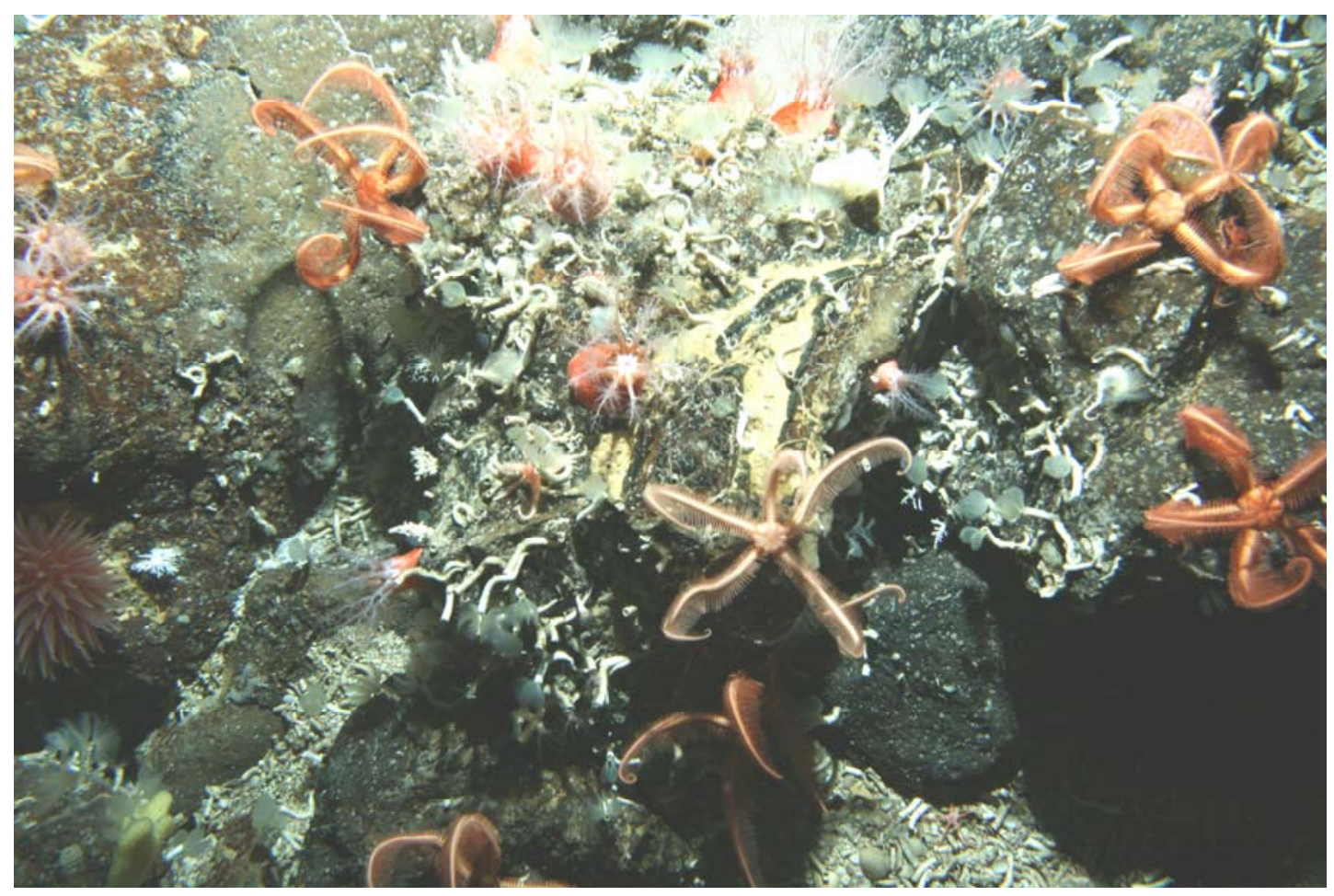

Plate 5. Starfish and tube worms cling to a glassy lava flow on seamount 6.

Note: This chapter was prepared as an article for submission to Bulletin of Volcanology.

Mechanisms of explosive mid-ocean ridge volcanic eruptions: evidence from the Macquarie Ridge Complex

Chris E. Conway ${ }^{1 *}$, Joel A. Baker ${ }^{1}$, Helen C. Bostock ${ }^{2}$, Richard J. Wysoczanski ${ }^{2}$

${ }^{1}$ Victoria University of Wellington, PO Box 600, New Zealand, ${ }^{2}$ National Institute of Water and Atmospheric Research, PO Box 14901, Wellington, New Zealand 


\section{ABSTRACT}

A petrological and geochemical investigation of glass occurring as quenched rinds on pillow lava and shards in volcaniclastic breccia samples from the submarine Macquarie Ridge Complex provides insight into the mechanisms of submarine basaltic eruptions at mid-ocean ridges. Samples are alkaline to sub-alkaline basalt, containing 46.5 - 51.2 wt.\% $\mathrm{SiO}_{2}, 5.2-9.1$ wt.\% $\mathrm{MgO}$ and $2.3-5.1$ wt.\% total alkalis. Numerous glass shards within individual volcaniclastic breccia samples define distinct compositional domains, indicating hyaloclasts in each sample derived from single and discrete magmatic sources. The majority of glass shards in breccia samples were fragmented by cooling-contraction granulation of effusively erupted lava. One sample has highly vesicular glass shards with alkaline, fractionated compositions and high phenocryst contents. The petrological and geochemical observations in this sample can be explained by crystal fractionation and volatile exsolution in the source magma during a stalled ascent, which led to magmatic fragmentation. Prolonged crustal residence of magma in shallow reservoirs generated deep submarine explosive eruptions at the relic Macquarie spreading centre. This is likely to have occurred during the final stages of magmatism at the Australia-Pacific plate boundary south of New Zealand when seafloor spreading was ultraslow or had ceased, which induced low degrees of partial melting and retarded magma ascent rates. This study adds to the known locations of pyroclastic midocean ridge deposits and confirms that magma ascent dynamics exert a primary control on the style of volcanic eruption of basaltic lavas in submarine settings.

\subsection{INTRODUCTION}

Submarine volcanic eruption styles are constrained by several factors and determine the nature of the volcanic deposits produced. Fragmentation of magma occurs by explosive processes through the expansion of dissolved magmatic volatiles or by non-explosive mechanisms through cooling-contraction granulation, bulk interaction steam explosivity or contact-surface steam explosivity (Head \& Wilson, 2003). If magma is not disrupted at all, lava is extruded effusively onto the 
ocean floor forming pillow, sheet and lobate flows (Gregg \& Fink, 1995; Head et al., 1996). Explosive submarine eruptions are possible if dissolved volatiles expand and coalesce during magma ascent, leading to fragmentation of the magma at the top of the conduit (McBirney, 1963; Sparks, 1978). The pressure of the water column above deep submarine volcanoes is sufficient to suppress juvenile gas exsolution such that bubble nucleation and associated explosive volcanism is precluded (Head et al., 1996). Thus, effusive lava eruption is expected for volcanism occurring deeper than ca. 1,000 m below sea-level (Kokelaar, 1986).

Pyroclastic deposits generated by magmatic explosivity, however, have been documented along the Mid-Atlantic Ridge (MAR) at water depths of $c a$. 1,700 m (Fouquet et al., 1998) and ca. 2,000 m (Hekinian et al., 2000), on Loihi Seamount at ca. 2,000 m (Clague et al., 2003), on the slow-spreading Gakkel ridge, Arctic Ocean, at ca. 4,000 m (Sohn et al., 2008) and on the North Arch volcanic field, Hawaii, at water depths exceeding 4,200 m (Clague et al., 1990; Davis \& Clague, 2006). Explosive magma disruption at these sites is indicated by textural characteristics of pyroclasts and the observation that depths of eruption exceed the critical point of seawater (above which seawater cannot boil to form steam; Head \& Wilson, 2003; Clague et al., 2009a). A requirement for magmatic explosivity at such depths (and pressures) is that the magma must have a volatile content sufficient to generate the critical gas volume necessary to cause magma disruption (Sparks, 1978; Head \& Wilson, 2003). While the majority of mid-ocean ridge basalts (MORB) do not meet this requirement, alkalic magmas have greater volatile (e.g. $\mathrm{H}_{2} \mathrm{O}$ and $\mathrm{CO}_{2}$ ) concentrations than tholeiitic magmas and are capable of producing explosive eruptions at depths greater than 1,000 m (Dixon et al., 1997).

A critical gas fraction can also be reached by enhancing the initial volatile content of the magma due to a low magma ascent rate or a sealed dike-top. In these scenarios bubbles ascend, coalesce and reach a concentration sufficient to generate magma disruption during strombolian or vulcanian eruption (Head \& Wilson, 2003). A special case may occur whereby magma undergoes volatile exsolution in a shallow reservoir until the critical gas volume fraction is reached and the unstable 'magmatic foam' is erupted in a submarine hawaiian-style eruption (Bottinga \& 
Javoy, 1990; Head \& Wilson, 2003). Such scenarios may be especially relevant for slow-spreading mid-ocean ridges (Sohn et al., 2008). The different reservoir dynamics and eruption styles can be distinguished by the characteristics of the subsequent deposits (see guide in Head \& Wilson, 2003).

Pyroclastic mid-ocean ridge eruptions are ubiquitous over a range of water depths and magma compositions (Clague et al., 2009a). Despite these factors being firstorder variables, the ascent nature of the magma is also critical in determining submarine eruptive style. Here we explore the influence of these different factors in a petrological and geochemical study of basaltic glass in pillow lava and volcaniclastic breccia samples from the submarine Macquarie Ridge Complex (MRC). These samples represent the products of volcanism the relic Macquarie spreading centre and are therefore relevant for studies of mid-ocean ridge eruption dynamics. The range in location, composition and texture of the samples allows an evaluation of the different processes that give rise to the submarine eruption of basaltic lava. The results have implications for explosive eruptive activity at all sites of submarine volcanism with most significance for deep and/or slow-spreading midocean ridges.

\subsection{GEOLOGICAL SETTING OF THE MACQUARIE RIDGE COMPLEX}

The MRC forms the submarine expression of the Australia-Pacific plate boundary south of New Zealand and is a prominent 1,600 km-long bathymetric ridge in the Southern Ocean (Fig. 4.1 inset). The MRC comprises four segments, separated by breaks in the ridge axis and divided according to their orientation; from north to south these are the Puysegur, McDougall, Macquarie and Hjort segments (Fig. 4.1; Massell et al., 2000). The ridge crest has a rough topography giving rise to discrete, elevated seamounts features as it undulates from near-sea-level to $>1,000 \mathrm{~m}$ water depth along its length (Chapter 3 ). Macquarie Island $\left(54^{\circ} 30^{\prime} \mathrm{S}\right.$ ) is the sole subaerial exposure of the MRC and is located on the Macquarie segment (Fig. 4.1). 


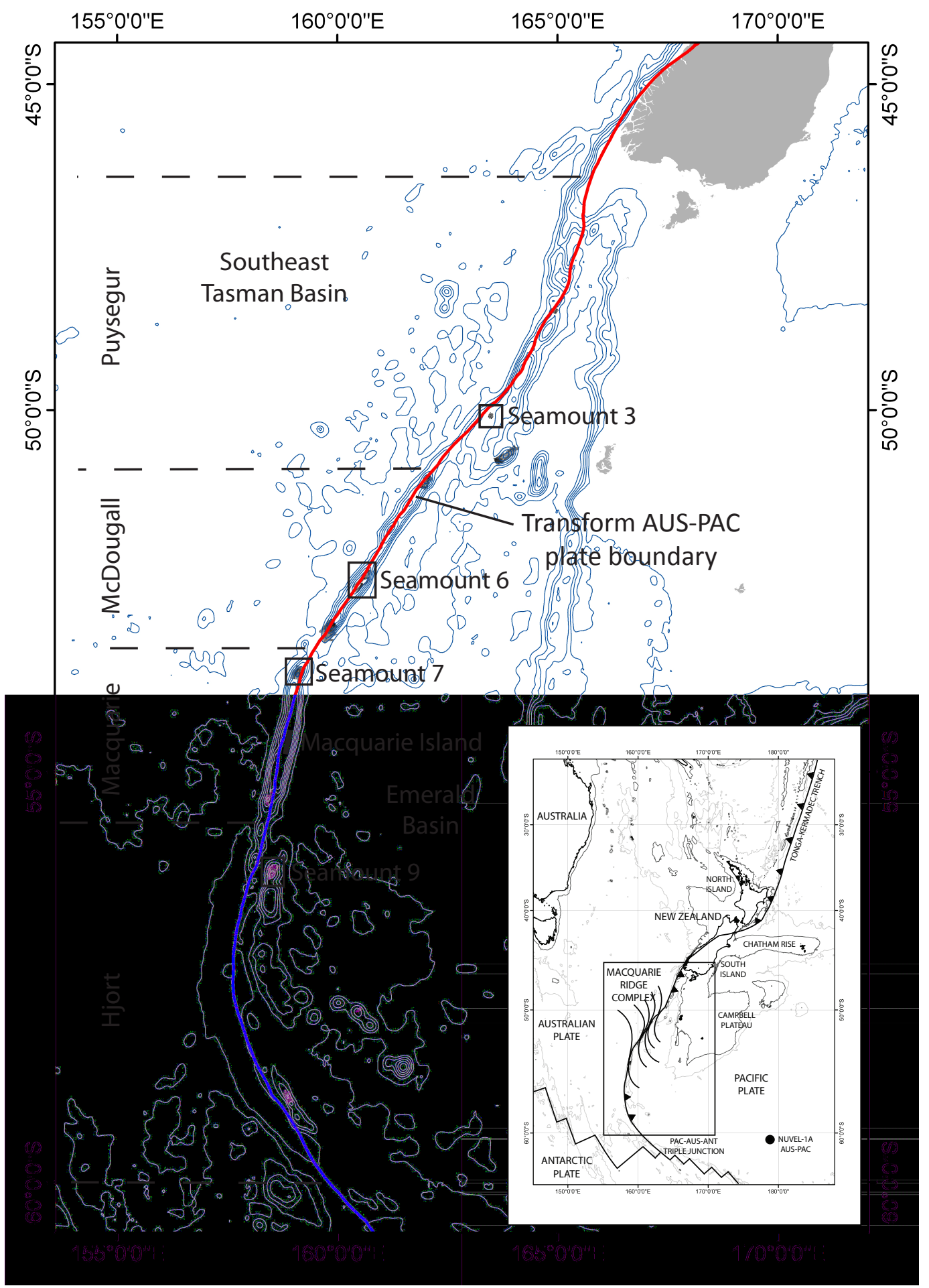

Figure 4.1. Location map of the MRC and sample sites. The MRC coincides with the AustraliaPacific transform plate boundary (red line) south of New Zealand. Volcanic glass samples were recovered by dredging at the 4 seamounts identified. Inset displays position of the MRC in the Southern Ocean. Black circle represents pole of relative plate motion (De Mets et al., 1994). Presence and direction of subduction shown by black triangles along Australia-Pacific plate boundary. 
Kinematic plate reconstructions show that the Australia-Pacific plate boundary south of New Zealand evolved from a spreading ridge to a transform boundary from ca. 40 to $6 \mathrm{Ma}$ (Walcott, 1984; Lamarche et al., 1997; Mosher \& Massell-Symons, 2008). Seafloor spreading rates were ca. $2 \mathrm{~cm} \mathrm{a}^{-1}$ between 30 and $10 \mathrm{Ma}$ (Wood et al., 1996). Herein we refer to the divergent plate boundary in the past as the relic Macquarie spreading centre. Oceanic crust formed at the past spreading centre now forms the modern MRC (Massell et al., 2000; Chapter 3). Geochemical studies of MRC oceanic crust have been confined to Macquarie Island; an uplifted ophiolite suite of crustal and mantle rocks generated at the waning spreading ridge (Griffin \& Varne, 1980; Goscombe \& Everard, 1998). The volcanic rocks are predominantly EMORB with minor normal (N-) MORB affinities (Kamenetsky \& Maas, 2002).

Investigation of glass shards in volcaniclastic breccias in several studies on Macquarie Island has provided insight into the mechanisms of volcaniclastic rock formation at mid-ocean ridges. Three key characteristics are indentified: a tight compositional domain defined by samples of the same unit (Portner et al., 2009); preservation of distinct geochemical features between units (Daczko et al., 2009); textural characteristics indicating deposition while grains were hot (Dickinson et al., 2009). These features constrain a model for the formation of Macquarie breccias: destabilisation of a growing pillow cone resulted in a voluminous eruption phase responsible for the fragmentation, transportation and emplacement of glass and pillow lava clasts down-slope of the cone. The narrow major and trace element compositional range defined by numerous glass grains in each Macquarie Island breccia sample is consistent with derivation from a single magmatic source (Daczko et al., 2009).

\subsection{SAMPLES AND METHODS}

Rock samples were obtained by epibenthic sled dredging of MRC seamounts on cruise TAN0803, carried out by the National Institute of Water and Atmospheric Research (NIWA) on RV Tangaroa during March-April, 2008. The recovered material included 9 samples with fresh volcanic glass, collected from seamounts 3, 6, 7 and 9 
(Fig. 4.1; Table 4.1). Volcanic glass is present in the samples as quenched rinds of pillow lava (5 samples) and hyaloclasts in volcaniclastic breccia (4 samples). Glass taken from the samples was crushed into $1-5 \mathrm{~mm}$-long grains using an agate mortar and pestle and subsequently washed in a beaker filled with Milli-Q $\mathrm{H}_{2} \mathrm{O}$ (4 times) and methanol ( 1 time) that was placed in an ultrasonic bath for $3 \mathrm{~min}$ at a time. Petrological features of the washed glass grain were examined by optical microscopy and fresh, vitreous grains were picked and mounted in epoxy for analysis.

The nine samples were analysed at Victoria University Wellington using a JEOL JXA8230 SuperProbe electron probe micro-analyser (EPMA). KL2-G (basaltic glass, Kilauea, Hawaii) was used as a primary standard for major element oxides $\mathrm{SiO}_{2}$, $\mathrm{TiO}_{2}, \mathrm{Al}_{2} \mathrm{O}_{3}, \mathrm{FeO}_{\mathrm{T}}, \mathrm{MgO}, \mathrm{CaO}, \mathrm{K}_{2} \mathrm{O}$ and $\mathrm{Na}_{2} \mathrm{O}$. Beeson apatite was used to calibrate for $\mathrm{P}_{2} \mathrm{O}_{5}$ and a synthetic oxide was used to calibrate for $\mathrm{MnO}$. The instrument was operated under the following settings for analysis of sample and standard glasses: $15 \mathrm{kV}$ accelerating voltage, $8 \mathrm{nA}$ probe current, $20 \mu \mathrm{m}$ spot size. Samples and standards were measured for $30 \mathrm{~s}$ and background levels for $15 \mathrm{~s}$. International standards KL2-G (basaltic glass, Kilauea, Hawaii) and VG-A99 (basaltic glass, Makaopuhi, Hawaii) were analysed as unknowns throughout runs in order to monitor instrumental drift and the precision and accuracy of the EPMA analyses. Five spots on a homogeneous area of a single grain for pillow lava rind samples were acquired; ten spots on each of at least nine grains for individual breccia samples were analysed. Petrological features were examined by back-scattered electron (BSE) imaging.

\subsection{RESULTS}

Petrological features of samples are presented in Tables 4.1 and 4.2, and geochemical data in Table 4.3. A summary of previous analyses from Macquarie Island volcanic glasses is also given in Table 4.3 for comparative purposes. 
Table 4.1. Summary of information for MRC volcanic glass samples.

\begin{tabular}{|c|c|c|c|c|}
\hline Sample & Seamount & Location & Lithology & Petrology \\
\hline $33[205]$ & 3 & $\begin{array}{l}50^{\circ} 05^{\prime} 43^{\prime \prime} \\
163^{\circ} 28^{\prime} 93^{\prime \prime}\end{array}$ & Pillow lava rind & Non-vesicular, sparsely porphyritic \\
\hline $33[206]$ & 3 & $\begin{array}{l}50^{\circ} 05^{\prime} 43^{\prime \prime} \\
163^{\circ} 28^{\prime} 93^{\prime \prime}\end{array}$ & Pillow lava rind & Non-vesicular, sparsely porphyritic \\
\hline $38 \mathrm{~A}$ & 3 & $\begin{array}{l}50^{\circ} 05^{\prime} 83^{\prime \prime} \\
163^{\circ} 28^{\prime} 45^{\prime \prime}\end{array}$ & Pillow lava rind & Sparsely vesicular, sparsely porphyritic \\
\hline 69A & 6 & $\begin{array}{l}52^{\circ} 23^{\prime} 85^{\prime \prime} \\
160^{\circ} 39^{\prime} 40^{\prime \prime}\end{array}$ & Pillow lava rind & Sparsely vesicular, sparsely porphyritic \\
\hline $69 \mathrm{C}$ & 6 & $\begin{array}{l}52^{\circ} 23^{\prime} 85^{\prime \prime} \\
160^{\circ} 39^{\prime} 40^{\prime \prime}\end{array}$ & $\begin{array}{l}\text { Hyaloclastite-pillow } \\
\text { basalt breccia }\end{array}$ & $\begin{array}{l}\text { Angular grains, }<20 \mathrm{~mm} \text {, sparsely } \\
\text { vesicular, sparsely porphyritic }\end{array}$ \\
\hline $82[1241]$ & 7 & $\begin{array}{l}53^{\circ} 43^{\prime} 74^{\prime \prime} \\
159^{\circ} 09^{\prime} 78^{\prime \prime}\end{array}$ & Pillow lava rind & Sparsely vesicular, sparsely porphyritic \\
\hline $82[1242]$ & 7 & $\begin{array}{l}53^{\circ} 43^{\prime} 74^{\prime \prime} \\
159^{\circ} 09^{\prime} 78^{\prime \prime}\end{array}$ & Hyaloclastite breccia & $\begin{array}{l}\text { Angular grains, }<15 \mathrm{~mm} \text {, sparsely } \\
\text { vesicular, non-porphyritic }\end{array}$ \\
\hline $98 \mathrm{~A}$ & 9 & $\begin{array}{l}56^{\circ} 14^{\prime} 78^{\prime \prime} \\
158^{\circ} 30^{\prime} 34^{\prime \prime}\end{array}$ & Volcaniclastic breccia & $\begin{array}{l}\text { Angular grains, }<10 \mathrm{~mm} \text {, highly } \\
\text { vesicular, highly porphyritic }\end{array}$ \\
\hline 102 & 9 & $\begin{array}{l}56^{\circ} 14^{\prime} 53^{\prime \prime} \\
158^{\circ} 27^{\prime} 70^{\prime \prime}\end{array}$ & Hyaloclastite breccia & $\begin{array}{l}\text { Angular grains, }<10 \mathrm{~mm} \text {, non-vesicular, } \\
\text { non-porphyritic }\end{array}$ \\
\hline
\end{tabular}

\subsubsection{Petrology}

Sideromelane glass shards in breccia samples from the MRC are sub-angular to angular, ranging in shape from equant-elongate to sub-spherical and from $1-20$ $\mathrm{mm}$ in length. Minor amounts of fresh glass exist in the breccias due to hydrothermal alteration of the matrix to orange palagonite. Relic glass grains and altered edges of fresh glass are common. The majority of glass grains are non- to sparsely porphyritic and non- to sparsely vesicular and many display internal radial fractures (Fig. 4.2). Sample 98A contains highly vesicular and porphyritic glass shards (Fig. 4.2). Vesicles are rounded and up to $4 \mathrm{~mm}$ in length and phenocrysts are plagioclase and generally $100-200 \mu \mathrm{m}$ in length. Pillow lava fragments are present in breccia samples $69 \mathrm{C}$ and $98 \mathrm{~A}$ as $<60 \mathrm{~mm}$-long angular blocks of light grey, sparsely (69C) to highly (98A) vesicular and porphyritic basalt. Glass and pillow fragments are cemented by palagonite. Glass occurs as $2-10 \mathrm{~mm}$-thick quenched rinds on pillow lava samples and varies from being non- to sparsely vesicular and porphyritic (Fig. 4.2; Table 4.1). 
Table 4.2. Petrological features of volcaniclastic breccia samples from the MRC.

\begin{tabular}{|c|c|c|c|c|}
\hline Sample & Lithology & Breccia components & Glass characteristics & Pillow characteristics \\
\hline $69 \mathrm{C}$ & $\begin{array}{l}\text { Pillow fragment- } \\
\text { hyaloclastite breccia } \\
\text { (palagonite cement) }\end{array}$ & $\begin{array}{l}-5 \% \text { fresh glass } \\
-30 \% \text { pillow fragments } \\
-30 \% \text { relict glass grains } \\
-35 \% \text { palagonite } \\
\text { matrix/cement }\end{array}$ & $\begin{array}{l}\text {-angular; elongate- } \\
\text { rectangle shape } \\
-<20 \mathrm{~mm} \\
\text {-sparsely vesicular, } \\
\text { sparsely porphyritic }\end{array}$ & $\begin{array}{l}\text {-light-grey } \\
\text {-angular; blocky } \\
\text {-sparsely vesicular \& } \\
\text { porphyritic } \\
-<60 \mathrm{~mm} \\
\text {-quenched glass rinds }\end{array}$ \\
\hline $82[1242]$ & $\begin{array}{l}\text { Hyaloclastite breccia } \\
\text { (palagonite-calcite } \\
\text { cement) }\end{array}$ & $\begin{array}{l}-30 \% \text { fresh glass } \\
-10 \% \text { relict glass grains } \\
-60 \% \text { palagonite } \\
\text { matrix/cement }\end{array}$ & $\begin{array}{l}\text {-angular; spherical- } \\
\text { elliptical } \\
\text {-<15 mm } \\
\text {-vesiculated edges } \\
\text {-sparsely vesicular, } \\
\text { sparsely porphyritic }\end{array}$ & $\mathrm{n} / \mathrm{a}$ \\
\hline $98 \mathrm{~A}$ & $\begin{array}{l}\text { Volcaniclastic breccia } \\
\text { (palagonite cement) }\end{array}$ & $\begin{array}{l}-10 \% \text { fresh glass } \\
-20 \% \text { pillow fragments } \\
-20 \% \text { relict glass grains } \\
-50 \% \text { palagonite } \\
\text { matrix/cement }\end{array}$ & $\begin{array}{l}\text {-angular; blocky- } \\
\text { rectangular } \\
-<10 \mathrm{~mm} \\
\text {-highly vesicular and } \\
\text { porphyritic }\end{array}$ & $\begin{array}{l}\text {-light grey } \\
\text {-angular; blocky } \\
\text {-highly vesicular \& } \\
\text { porphyritic } \\
-<60 \mathrm{~mm} \\
\text {-quenched glass rinds }\end{array}$ \\
\hline 102 & $\begin{array}{l}\text { Hyaloclastite breccia } \\
\text { (palagonite cement) }\end{array}$ & $\begin{array}{l}-30 \% \text { fresh glass } \\
-10 \% \text { relict glass grains } \\
-60 \% \text { palagonite } \\
\text { matrix/cement }\end{array}$ & $\begin{array}{l}\text {-angular; blocky- } \\
\text { elliptical } \\
-<10 \mathrm{~mm} \\
\text {-non-vesicular, non- } \\
\text { porphyritic }\end{array}$ & $\mathrm{n} / \mathrm{a}$ \\
\hline
\end{tabular}

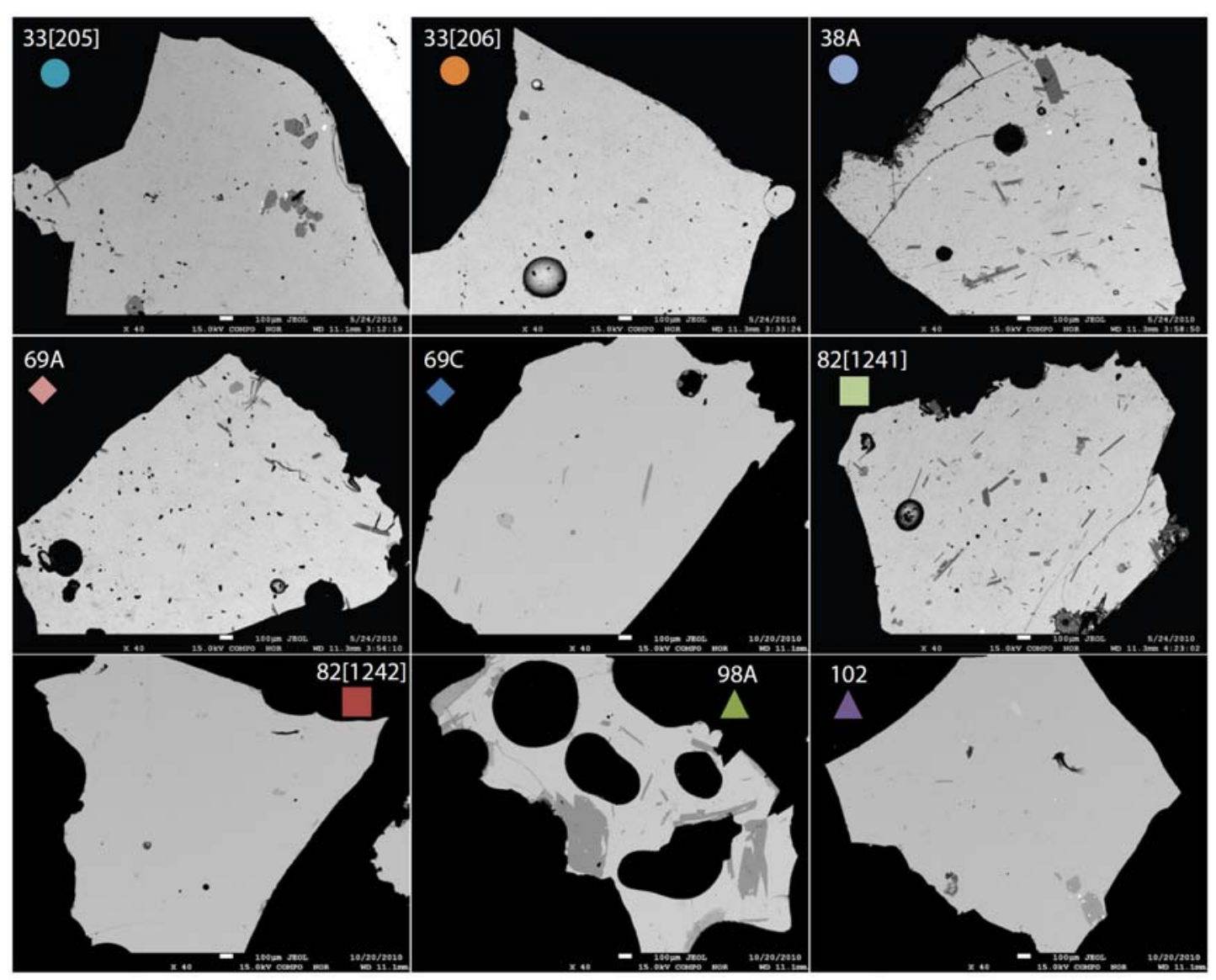

Figure 4.2. Representative BSE images for MRC volcanic glass samples. Scale shown by white bar on each image (100 microns). Symbols apply to Figures 4.3 and 4.4. 


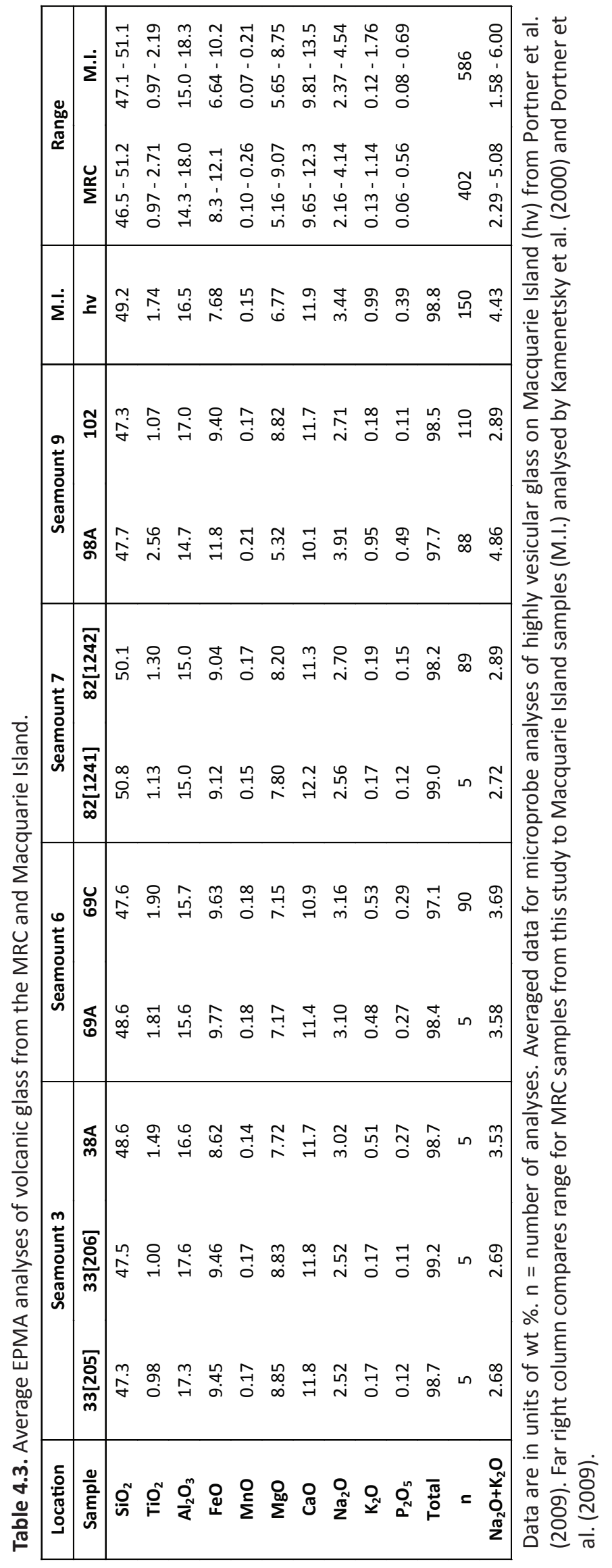




\subsubsection{Geochemistry}

At least nine grains from each volcaniclastic breccia sample were analysed in order to investigate the compositional range of glass shards within an individual sample. The four segments of the MRC (Puysegur, McDougall, Macquarie and Hjort) are each represented by one seamount with 2 to 3 volcanic glass samples in this study. Each breccia sample defines a tight and distinct compositional cluster in total alkali versus silica space and the major element oxide bivariate plots (Figs. 4.3, 4.4).

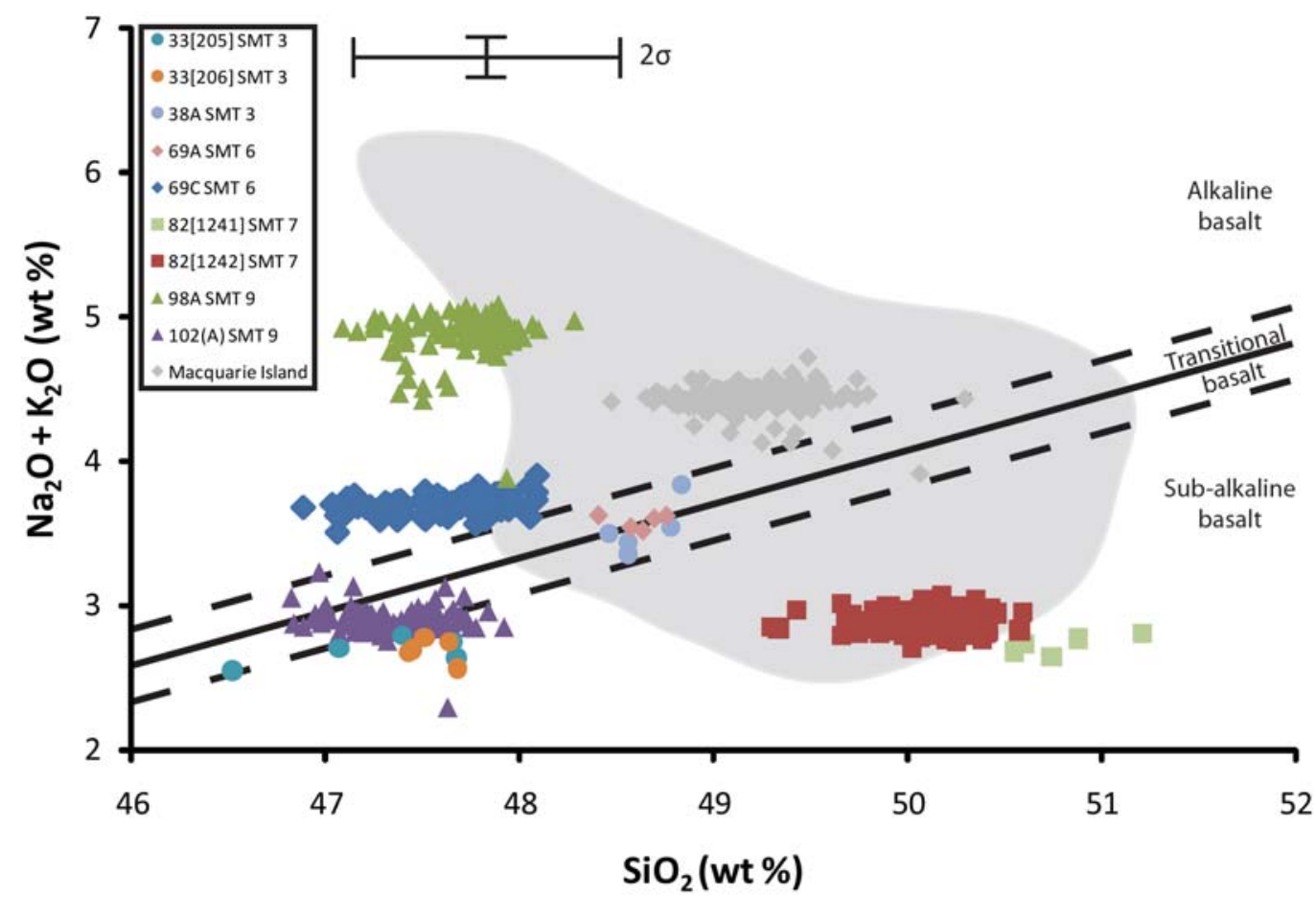

Figure 4.3. Total alkalis-silica diagram for MRC glass samples. Grey field denotes the compositional range of Macquarie Island samples (Kamenetsky et al., 2000; Portner et al., 2009). Grey symbols are analyses of glass from high vesicularity breccia lithofacies on Macquarie Island (Portner et al., 2009). $2 \sigma$ error bars from EPMA analyses of volcanic glass KL2-G are shown. Transitional basalt field from MacDonald and Katsura (1969).

The samples have a compositional range from sub-alkaline basalt (33[206], 82[1241]A, 82[1242]A) to transitional basalt (33[205], 38A, 69A, 102) to alkaline (69C, 98A) basalt (Fig. 4.3). Compared to glass from Macquarie Island, MRC samples range to lower-silica, lower-alkali compositions (33[205], 33[206], 102) and to a higher-silica, lower alkali composition (82[1241]A; Fig. 4.3). Macquarie Island samples extend to significantly higher total alkali contents (over $1 \mathrm{wt}$ \% higher than 98A, the most alkali-rich of the submarine MRC samples). However, sample 98A has 

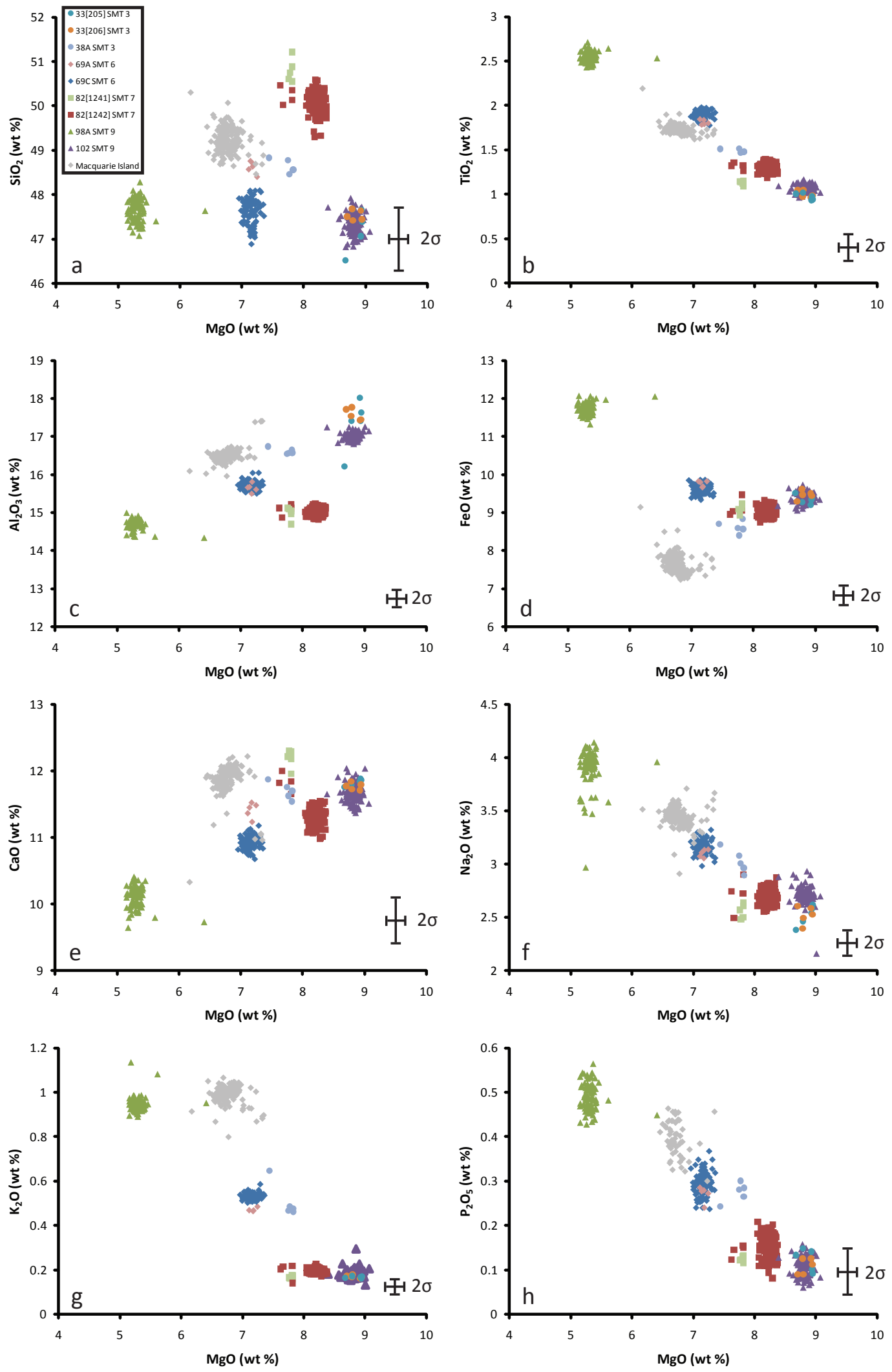

Figure 4.4. Bivariate major element-MgO diagrams for MRC samples. $2 \sigma$ error bars from EPMA analyses of volcanic glass standard are shown for each element. Grey symbols are analyses of glass from high vesicularity breccia lithofacies on Macquarie Island (Portner et al., 2009). 
a higher alkali content than the high vesicularity lithofacies from Macquarie Island (Fig. 4.3; Portner et al., 2009). There is no systematic variation between glass composition and sample location as shown by the compositional overlap of samples from different seamounts (e.g. samples 33[205 and 206] from seamount 3 and sample 102 from seamount 9) and the range in composition between samples from the same seamount (e.g. samples $98 \mathrm{~A}$ and 102 from seamount 9; Figs. 4.3, 4.4).

\subsection{DISCUSSION}

Glass shards from individual volcaniclastic breccia samples define tight major element compositional clusters that are less than the analytical uncertainty for each oxide (Figs. 4.3, 4.4; Chapter 2, Table 2.3), indicating that shards for each sample originate from a single magmatic source (Daczko et al., 2009). Analytical precision of EPMA analyses is presented in Chapter 2 (see Table 2.3). The angular hyaloclasts in breccia samples 69C, 82[1242]A and 102 have low vesicle and phenocryst contents (Fig. 4.2; Table 4.2). Such textural characteristics indicate the shards were produced by cooling-contraction granulation of quenched pillow lava rinds (Kokelaar, 1986; Clague et al., 2000a). Furthermore, their compositional and petrologic features are shared by glass rinds from pillow lava samples (Figs. 4.2, 4.4). The low vesicle and phenocryst contents and relatively high $\mathrm{MgO}$ contents in these glasses indicate their source magmas rose efficiently through the conduits and were erupted as effusive lava flows near the vents. Upon contact with seawater, lava was quenched and then granulated as pillow head interiors cooled and contracted, producing glass and lava fragments that comprise the volcaniclastic samples (Kokelaar, 1986). This is the dominant mechanism for producing hyaloclasts in volcaniclastic samples exposed on Macquarie Island (Dickinson et al., 2009). The dredge sampling technique precludes stratigraphic investigation of modes of grain transport and deposition in this study. However, this has been achieved for samples on Macquarie Island where stratigraphic relationships can be explored: following the eruption and fragmentation of lava, grains are transported and deposited down-slope of the volcanic vent by debris or grain flow (Daczko et al., 2009). 
Highly vesicular glass shards in volcaniclastic rocks are associated with fragmentation by magmatic explosivity (Davis and Clague, 2006). The mode of fragmentation (i.e. type of explosive eruption) can be distinguished based on the nature of the pyroclastic deposit (Head \& Wilson, 2000), which we evaluate for sample 98A and highly vesicular breccia from Macquarie Island. Clague et al. (2009a) recognise that angular, dense (low vesicularity) glass grains and limu o Pele shards most likely originate from spatter and cooling-contraction granulation of lava erupted during strombolian eruptive activity. This type of eruption is inconsistent with the texture of glass shards in highly vesicular MRC and Macquarie Island volcaniclastic rocks (Table 4.2; Portner et al., 2009). The occurrence of non-juvenile material in Macquarie Island pyroclastic deposits (Portner et al., 2009) indicates country rock around the volcanic vent was fragmented during the eruption. Both vulcanian and submarine hawaiian-type eruptions may generate fragmentation and inclusion of country rock in the pyroclastic deposit (Head \& Wilson, 2003). However, vulcanian eruptions will produce minor hyaloclastite deposits, whereas submarine hawaiian-type eruptions will generate density flows and widespread deposits of hyaloclastite breccia resulting from magmatic fragmentation (Head \& Wilson, 2003). Macquarie Island pyroclastic deposits display sedimentary structures and fabrics consistent with deposition via high-density, coarse-grained gravity flows and thus, hawaiian-type eruptions have been proposed to produce these breccias (Portner et al., 2009).

Petrological and geochemical features of highly vesicular glass shards in sample 98A are similar to those described for highly vesicular breccia lithofacies on Macquarie Island (Portner et al., 2009) and the volcaniclastic rocks may share a common eruptive history. These samples display unique features compared to low vesicularity breccias: an alkaline, fractionated composition and high phenocryst content. Alkaline magmas are generated by low degrees of partial melting beneath mid-ocean ridges (Klein \& Langmuir, 1987). The fractionated composition (i.e. low $\mathrm{MgO}$ content) of the glass in breccia sample 98A can be explained by crystallization of the source magma in its reservoir (e.g. Bender et al., 1978). The abundant plagioclase phenocrysts in the glass shards (Fig. 4.2) are more likely to be the result 
of crystallisation due to magmatic degassing and the loss of water during decompression (Cashman, 1992) than crystallisation in the magma chamber.

The evolved composition of sample 98A (lowest MgO content of all MRC and Macquarie Island samples; Table 4.3) indicates that its source magma underwent significant crystal fractionation prior to eruption. This entails a scenario whereby magma ascent was stalled, resulting in crystallization and degassing of the melt. Such a scenario is consistent with submarine hawaiian-type eruption dynamics: a gas-rich magmatic foam forms from a slowly degassing shallow reservoir and is eventually evacuated as a jet or fountain of pyroclastic material (Head and Wilson, 2003). While the original volatile content in the source magma of high vesicularity glass from the MRC was high due to their alkaline composition (Dixon et al., 1997), the stalled ascent generated a greater volatile concentration at the top of the reservoir. Crystal fractionation further concentrated the volatile content in the residual magma (Hekinian et al., 2000; Vergniolle \& Mangan, 2000).

Figure 4.5 outlines a model for volcanism at the relic Macquarie spreading centre. Magma with a primitive and transitional to sub-alkaline composition that rose efficiently to the seafloor was erupted effusively and cooled to form lava flows with low vesicle and phenocryst contents, or was granulated on contact with seawater to form hyaloclasts deposited in volcaniclastic breccias. More alkaline magmas that underwent crystal fractionation and volatile exsolution in shallow reservoirs were fragmented and erupted during submarine hawaiian-type eruptions. Glass and pillow lava clasts occurring in MRC sample 98A and the high vesicularity breccia lithofacies on Macquarie Island derive from explosive activity, resulting from the stalled ascent of their source magmas. Such a scenario is likely to have been prevalent during the final stages of magmatism at the relic Macquarie spreading centre when seafloor spreading was slow (or had ceased) and low degrees of partial melting produced more alkaline magmas. High alkali and volatile element contents in MORB are a pre-requisite, and stalled magma ascent a co-requisite, for deep submarine explosive eruptions at mid-ocean ridges. Explosive submarine eruptions have been identified at slow-spreading and fossil ridges (Sohn et al., 2008; Clague et al., 2009a). We suggest the conditions necessary to generate deep submarine 
explosive eruptions are inherent to these sites of submarine volcanism due to their tendency to produce alkaline magmas and stall melt ascent as a result of relatively low tectonic and magmatic activity.

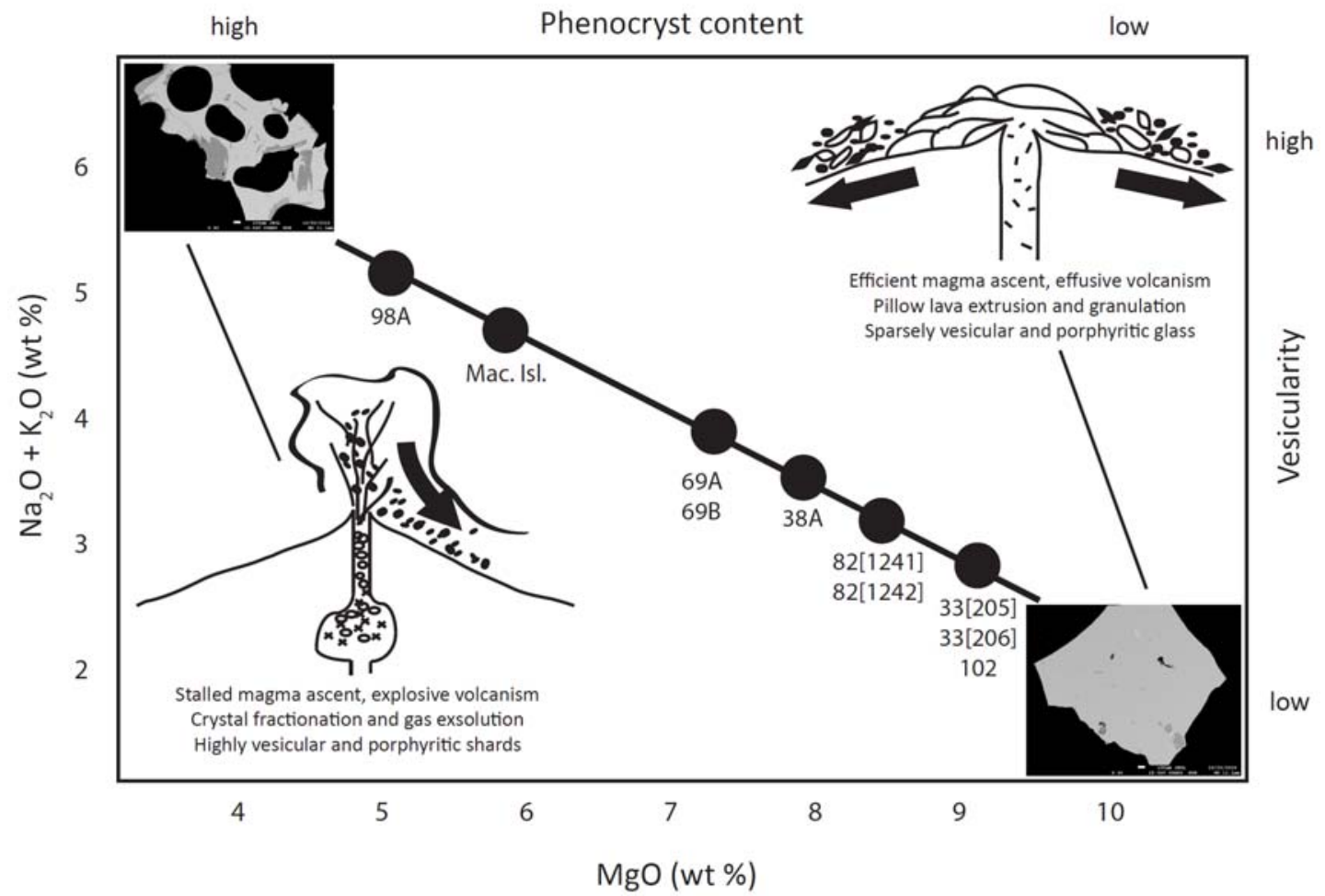

Figure 4.5. Eruption models (modified from Portner et al., 2009) for volcaniclastic rocks formed at the relic Macquarie spreading centre based on the relationship between glass petrology and geochemistry. Volcaniclastic breccia glass shards with high vesicle, phenocryst and alkali element contents and an evolved major element chemistry were generated by submarine explosive eruptions. Following a period of prolonged crustal residence to account for crystal fractionation and gas build-up in a shallow reservoir, magma was fragmented during submarine hawaiian-type eruptions. Primitive glass shards in hyaloclastite breccias with low vesicle, phenocryst and alkali element contents were produced by cooling-contraction granulation of pillow lava. These lavas were erupted effusively on the seafloor and granulated on contact with seawater.

\subsection{CONCLUSIONS}

1. Volcanic glass from pillow lava and volcaniclastic breccia samples from the submarine MRC is alkaline to sub-alkaline basalt in composition.

2. Numerous glass shards within individual volcaniclastic breccia samples define restricted and distinct compositional domains in bivariate major element diagrams indicating that shards were derived from single and discrete magmatic sources. 
3. Glass grains in volcaniclastic samples with primitive, sub-alkaline to transitional basaltic compositions and low vesicle and phenocryst contents were fragmented by cooling-contraction granulation of effusively erupted pillow lava.

4. Glass grains with fractionated, alkaline compositions and high vesicle and phenocryst contents in volcaniclastic sample 98A (and high vesicularity lithofacies from Macquarie Island) were generated by magmatic fragmentation during enhanced-hawaiian type eruptions.

5. Original volatile contents in alkaline magmas were enhanced through crystal fractionation and volatile exsolution via stalled magma ascent of low degree melts during slow-spreading or post-spreading magmatism at the relic Macquarie spreading centre.

6. Conditions required to generate deep submarine explosive eruption of MORB are inherent to slow-spreading and fossil ridges. 


\section{CHAPTER 5:}

\section{PETROGENESIS OF ENRICHED MID-OCEAN RIDGE BASALTS FROM THE}

MACQUARIE RIDGE COMPLEX

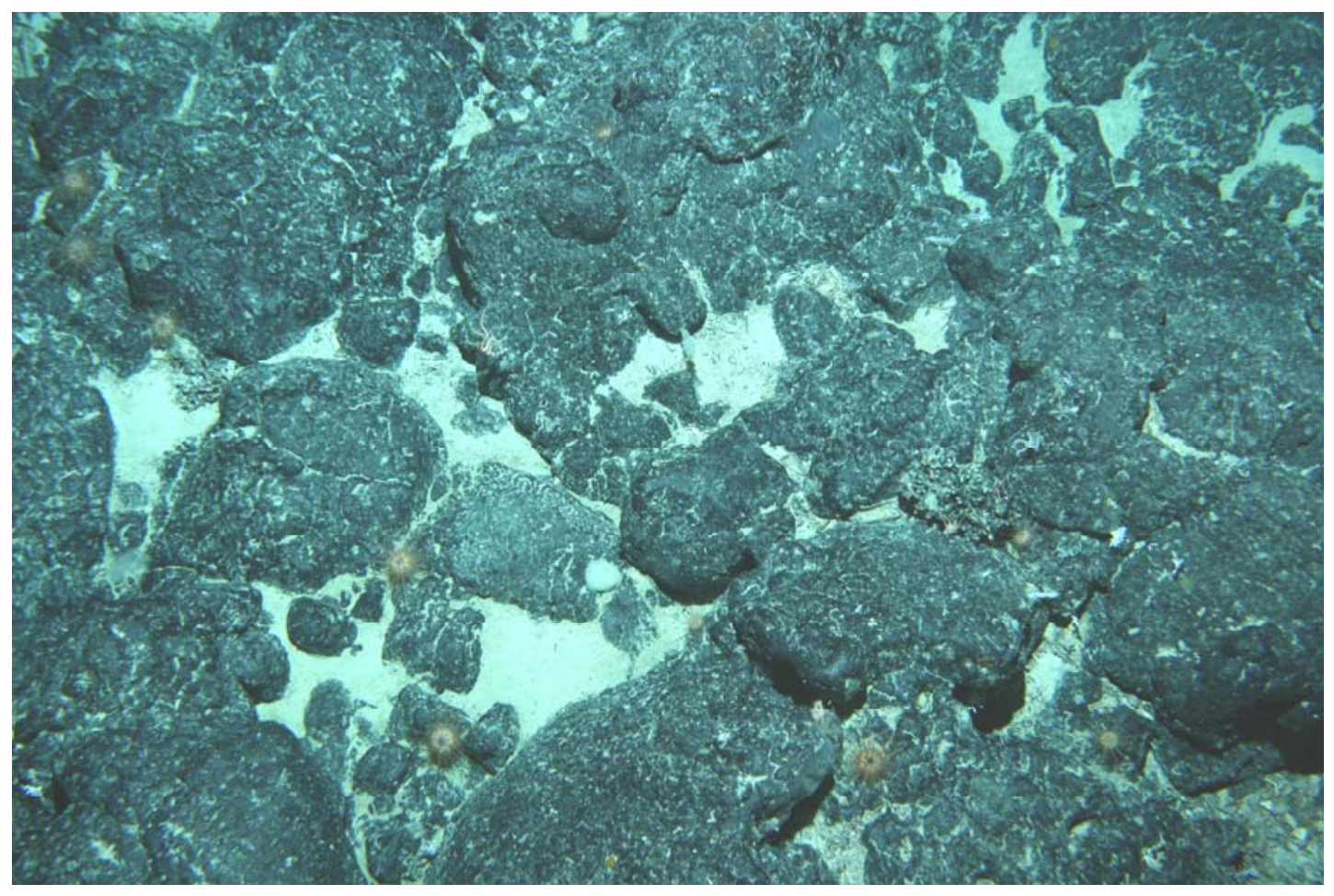

Plate 6. Pillow lavas on the Macquarie Ridge Complex seafloor. 


\subsection{INTRODUCTION}

Mid-ocean ridge basalts (MORB) are the product of adiabatic decompression melting of mantle material as it rises in response to plate separation at mid-ocean ridges (Bottinga et al., 1978). Thus, MORB record compositional features of the upper mantle, and the general compositional uniformity of lavas from the global mid-ocean ridge system suggests a similarly uniform and depleted upper mantle, i.e. the depleted MORB mantle (DMM; Zindler \& Hart, 1986). However, sampling of enriched-type (E-) MORB from mid-ocean ridges indicates that MORB may originate from a variety of mantle sources and processes (e.g. Niu \& Batiza, 1997). E-MORB are characterised by enrichments in incompatible elements and distinct radiogenic isotopic signatures compared to normal-type (N-MORB), which requires a mantle source that is relatively enriched in highly incompatible elements and has experienced low degrees of partial melting (Kay et al., 1970).

E-MORB signatures have been observed in discrete regions of plume-upper mantle interaction (e.g. southern Mid-Atlantic Ridge; le Roux et al., 2002), ultraslowspreading mid-ocean ridge volcanism (e.g. Gakkel Ridge; Mühe et al., 1997), off-axis seamount volcanism (e.g. East Pacific Rise; Niu \& Batiza, 1997), typical axial midocean ridge volcanism (e.g. $23^{\circ} \mathrm{N}$ on the Mid-Atlantic Ridge; Donnelly et al., 2004) and extinct spreading ridges (e.g. Phoenix Ridge; Haase et al., 2011). Models to explain the occurrence of E-MORB chemical characteristics in lavas sampled from such a range of volcano-tectonic settings have invoked the presence of geochemically enriched components in the upper mantle, which are incorporated into the melting regime beneath ocean ridges (e.g. Niu et al., 1999; Donnelly et al., 2004). Observations and models indicate that the sources of E-MORB occur as discrete and relatively small-scale heterogeneities in the otherwise depleted upper mantle.

The Macquarie Ridge Complex (MRC) is the submarine expression of the AustraliaPacific plate boundary south of New Zealand. The plate boundary evolved from divergent to transpressional relative plate motion from ca. 40 - 6 Ma (Mosher \& Massell-Symons, 2008), with seafloor spreading rates of $<2 \mathrm{~cm} \mathrm{a}^{-1}$ from $30-10 \mathrm{Ma}$ 
(Wood et al., 1996). Oceanic crust formed at the relic Macquarie spreading centre has since been sheared and accreted along the modern plate boundary to form the MRC (Chapter 3). Here it is shown that all volcanic rocks sampled over a latitudinal distance of $c a .1,200 \mathrm{~km}$ along the MRC display trace element signatures ranging from E-MORB to ocean island basalt (OIB). The origin of this pervasive trace element signature and the implications for mantle sources and processes beneath the relic Macquarie spreading centre are subsequently explored.

\subsection{SAMPLES}

Samples from the MRC were collected by epibenthic sled dredging of the MRC seafloor during voyage TAN0803 conducted by the National Institute of Water and Atmospheric Research (NIWA; Chapter 2). From the recovered material, 9 volcanic glass and 20 whole rock samples were selected for major and trace element chemical analyses (Table 5.1; see Chapter 3 for sample locations). Volcanic glass occurs as quenched rinds on pillow lava samples $(n=5)$ and hyaloclasts in volcaniclastic breccias $(n=4)$. Whole rock samples are dominantly plagioclasephyric basalt, with a small number of aphyric basalt, diabase and gabbro types (see Appendix 2 for petrographic description of samples).

\subsection{METHODS}

Volcanic glass samples were analysed for major element compositions by electron probe microanalysis (EPMA) at Victoria University of Wellington, New Zealand. Whole rock samples were analysed for major element compositions by X-ray fluorescence (XRF) spectrometry at SpectraChem Analytical, CRL Energy Ltd in Lower Hutt, Wellington, New Zealand. Volcanic glass and whole rock samples were prepared as solutions and analysed for trace element concentrations by inductively coupled plasma mass spectrometry (ICP-MS) at Victoria University of Wellington. Full descriptions of the methods employed for sample preparation and analysis are presented in Chapter 2. 


\subsection{RESULTS}

\subsubsection{Major element chemistry}

\subsubsection{Chemical classification}

Major element compositions of submarine MRC samples are presented in Table 5.1. The majority of samples are transitional basalts in a total alkalis-silica classification diagram, with all other samples plotting within the alkaline or sub-alkaline basalt fields (Fig. 5.1).

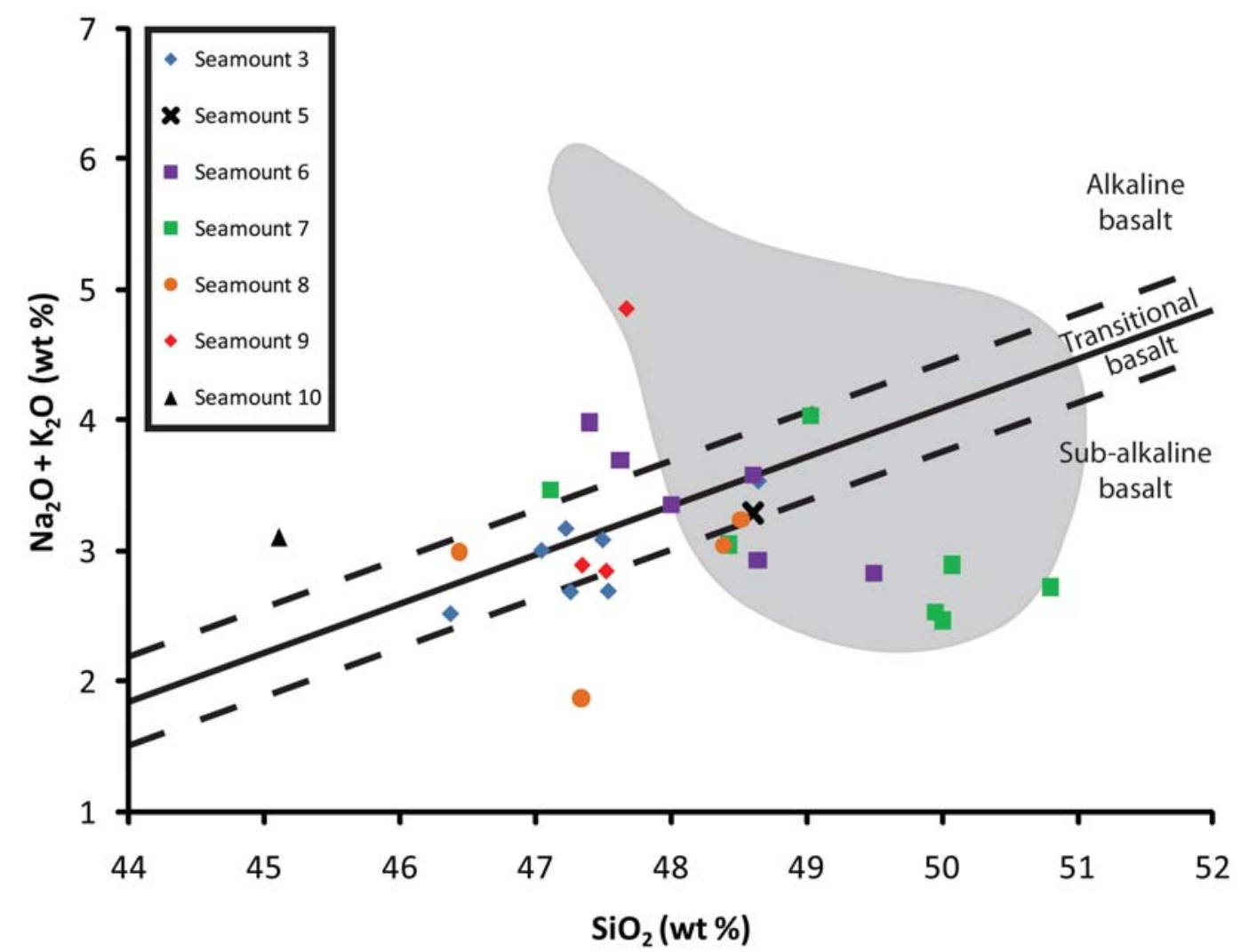

Figure 5.1. Total alkalis-silica classification diagram for MRC samples. Grey field denotes the compositional range of Macquarie Island samples (Kamenetsky et al., 2000; Portner et al., 2009). Alkaline basalt field is from Macdonald \& Katsura (1964).

Samples from seamount 3 plot in the low-alkali-low-silica domain of Figure 5.1, distinct from the Macquarie Island compositional field (Kamenetsky et al., 2000; Portner et al., 2009). Samples from seamounts 5 and 6 are generally transitional to sub-alkaline basalts that plot within the Macquarie Island compositional field (Fig. 5.1). Samples from dredge station 82 on seamount 7 form a distinct compositional domain in the low-alkali-high-silica quadrant of Figure 5.1. Other samples from 


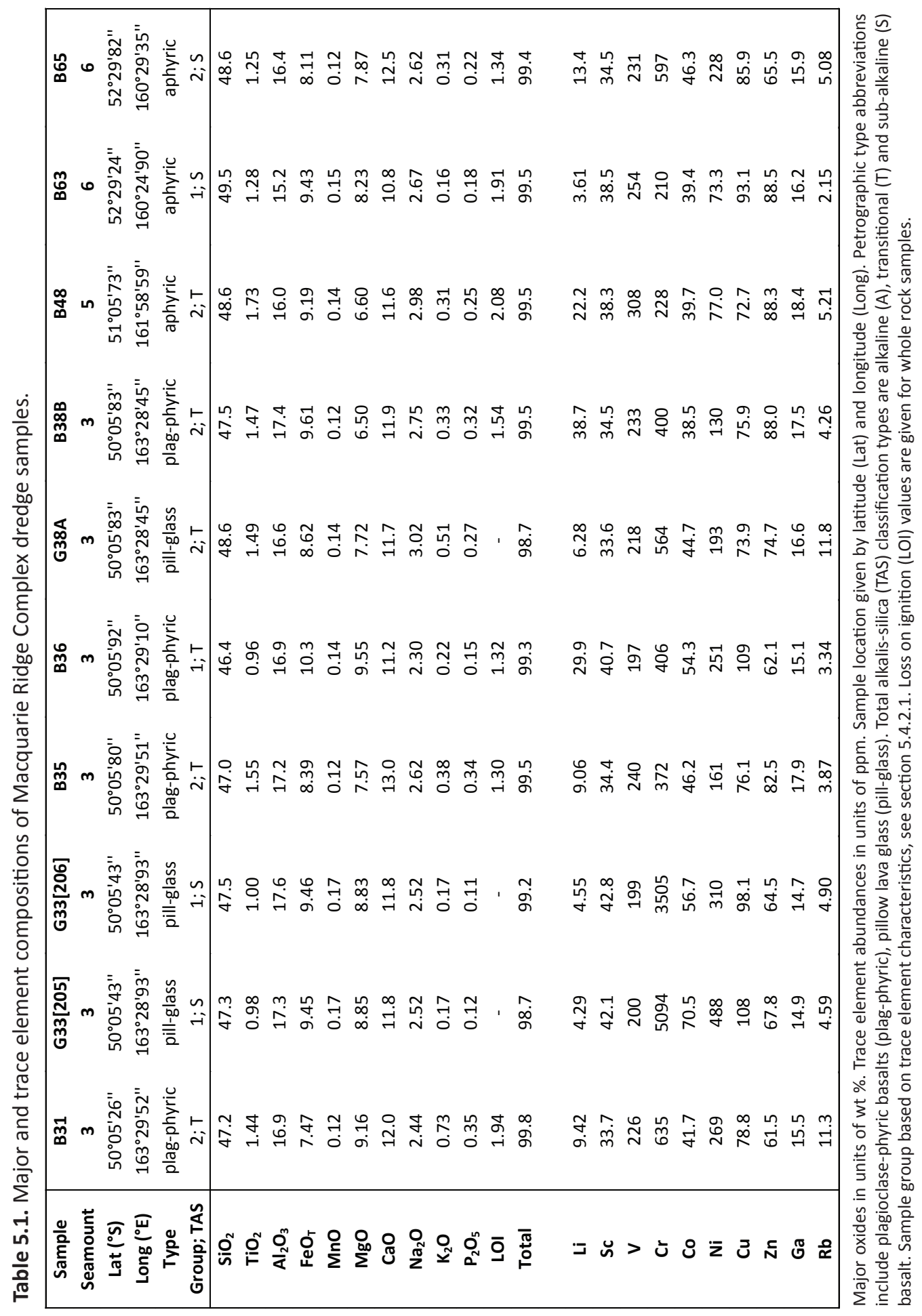




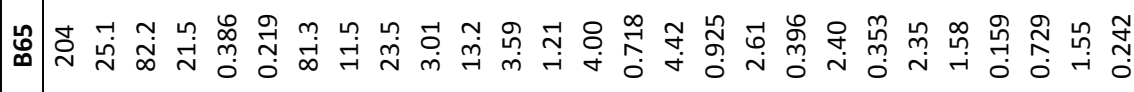

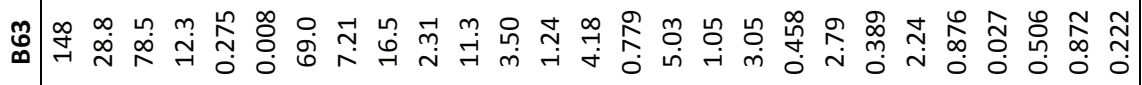

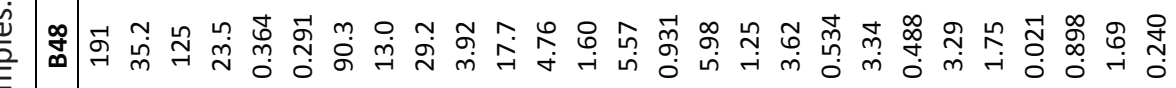

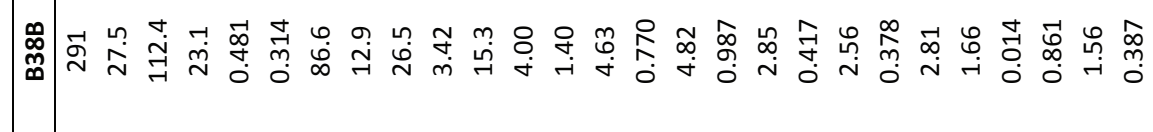

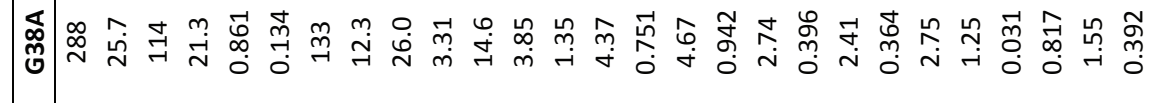

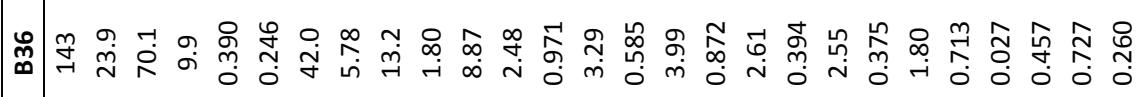

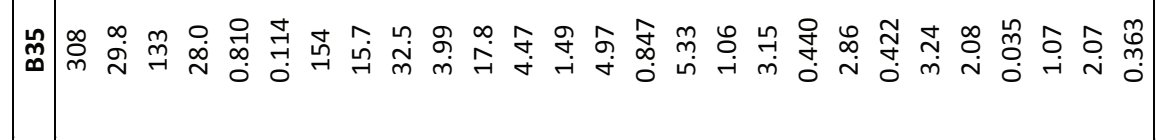

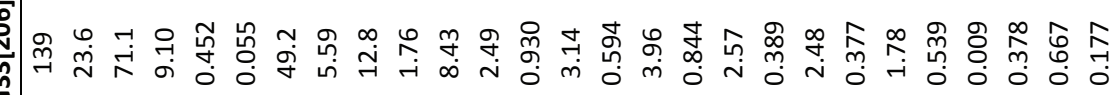

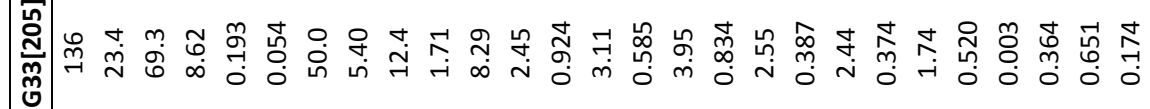

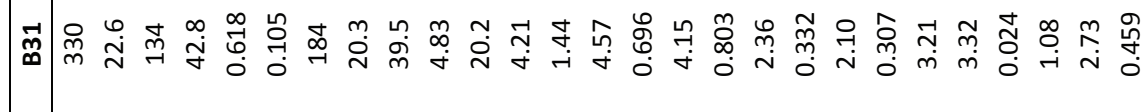

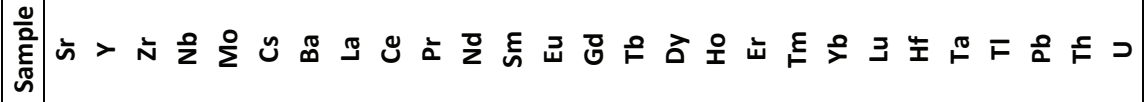




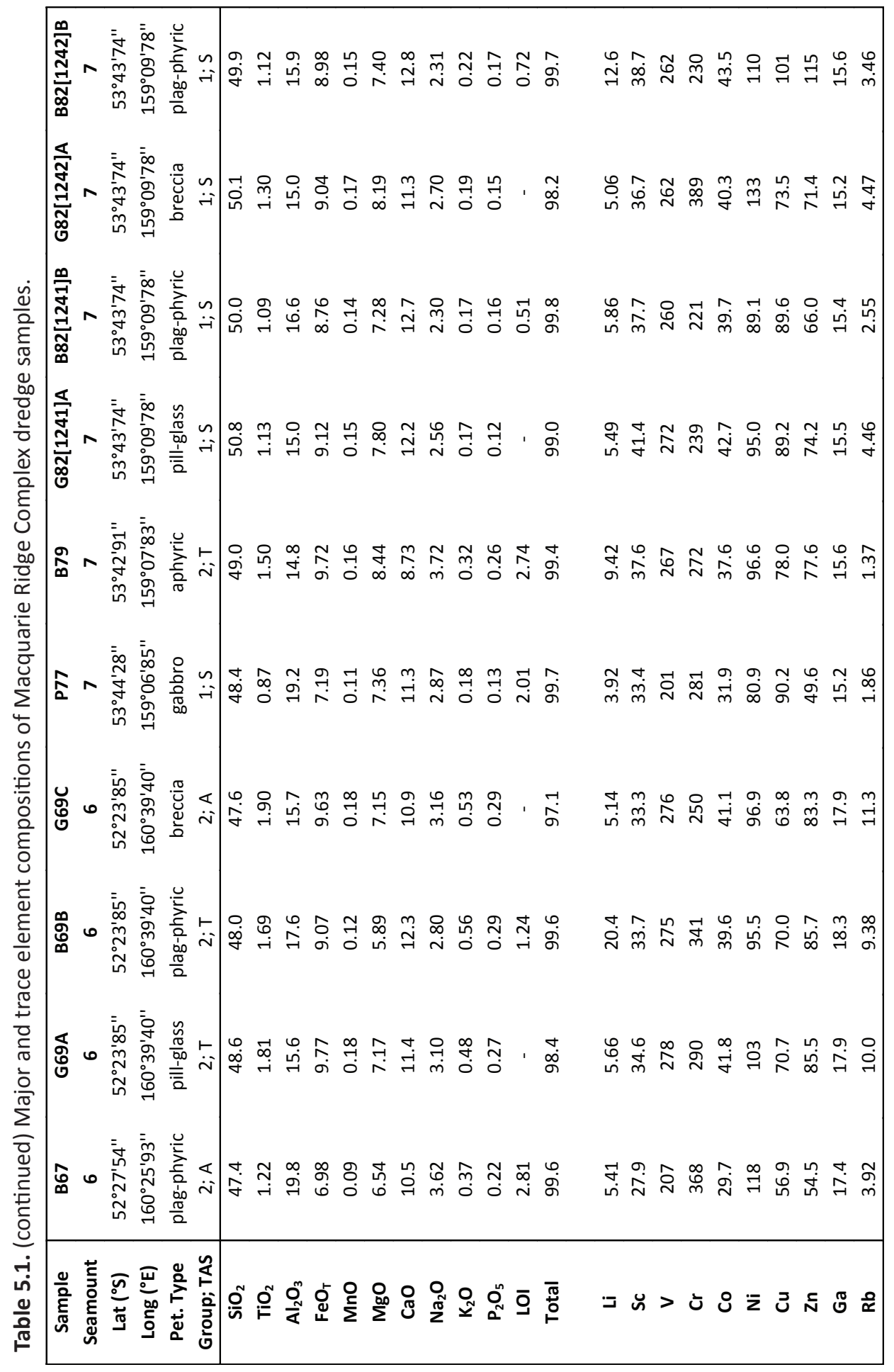




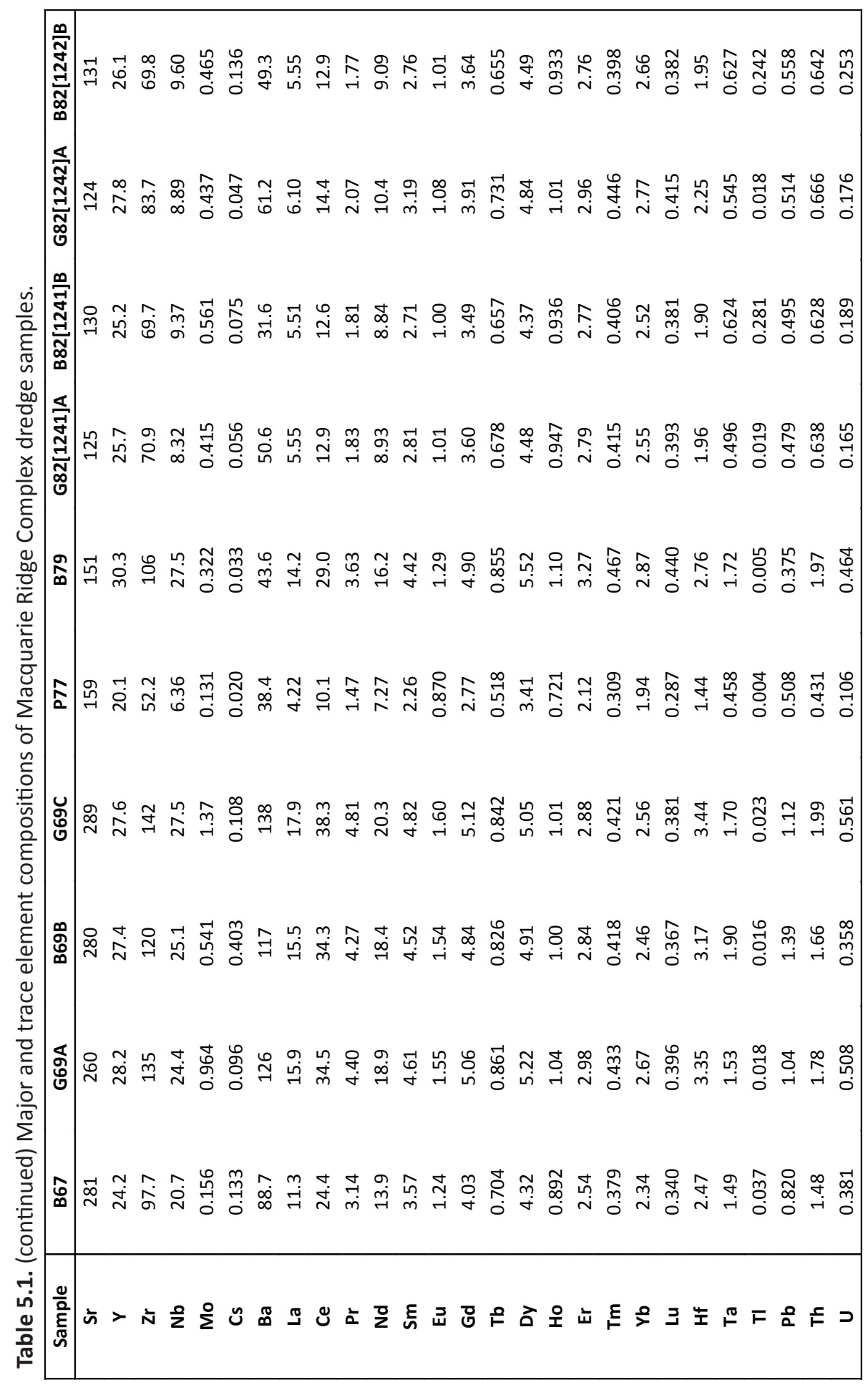




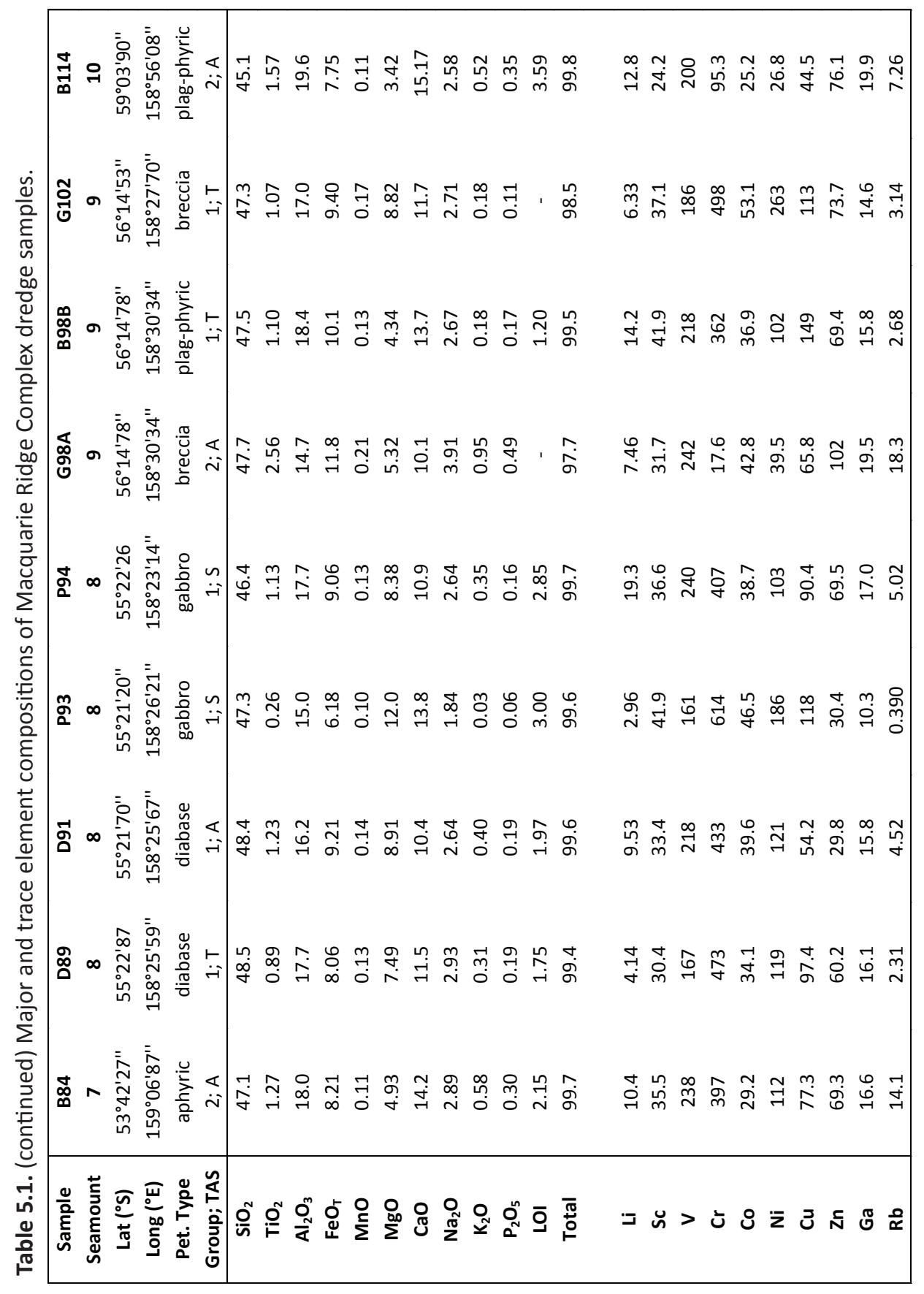




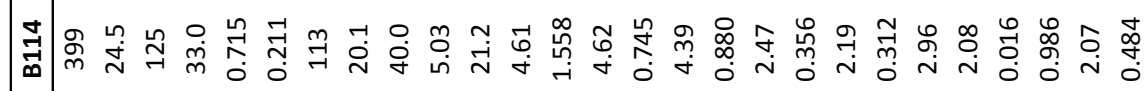

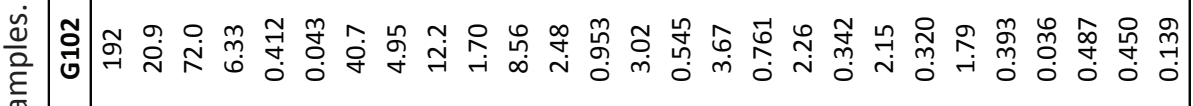

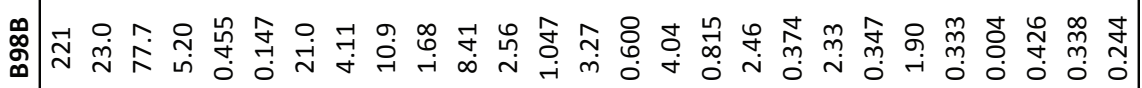

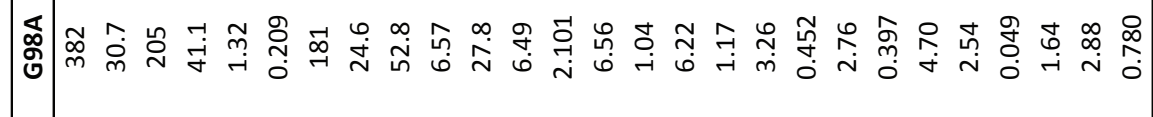

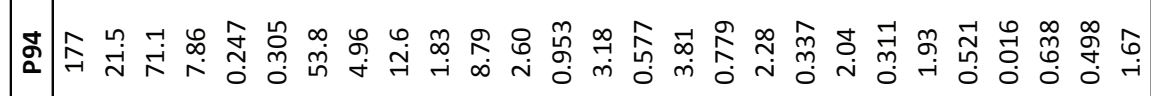

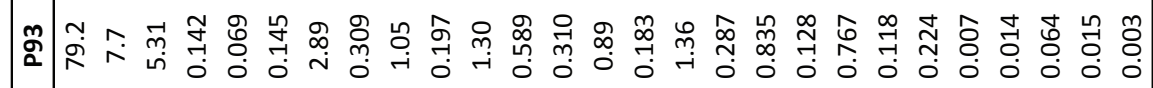

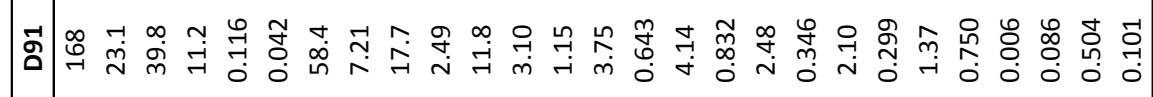

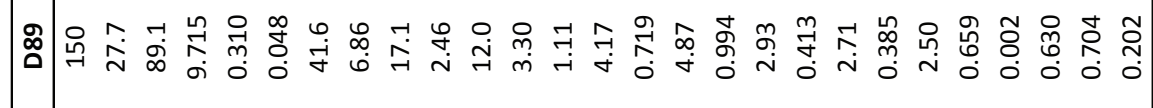

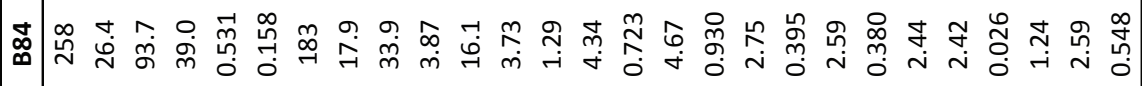

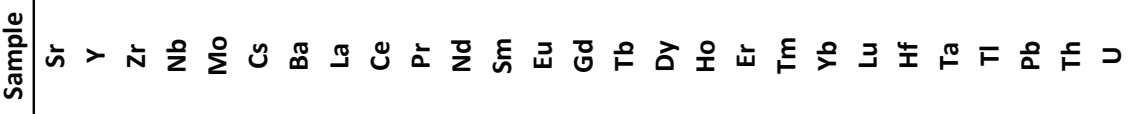


seamount 7 are alkaline, transitional and sub-alkaline basalts (Fig. 5.1). Plutonic and diabase samples from seamount 8 are indistinguishable from basaltic samples in their major element chemistry, except gabbro sample P93 (Table 5.1). Samples from seamount 9 are alkaline and transitional basalts, and display a range in major element composition, including the highest alkali element content of the sample suite (sample G98A; Fig. 5.1). Sample B114 is the only sample that was collected from seamount 10 and is a low-silica, alkaline basalt (Fig. 5.1).

\subsubsection{Bivariate MgO-major element diagrams}

MgO contents vary from 3.4 to $12.0 \mathrm{wt}$.\% in whole rock samples and from 5.3 to 9.2 wt.\% in glass samples; gabbro sample P93 is the only sample with $\mathrm{MgO}>10$ wt.\% (Table 5.1). Given sample P93 is a cumulate plutonic rock, its bulk rock chemistry is not representative of a melt composition and is therefore not included in further results or discussion. Bivariate diagrams of major elements versus $\mathrm{MgO}$ (Fig. 5.2) do not display any clear fractionation trends for the sample suite taken as a whole. At a given $\mathrm{MgO}$ content, samples display significant ranges in $\mathrm{SiO}_{2}, \mathrm{Al}_{2} \mathrm{O}_{3}$ and $\mathrm{FeO}$ contents of up to 5 wt.\% (Fig. 5.2).

\subsubsection{Trace element chemistry}

\subsubsection{Trace element concentrations}

The trace element compositions of submarine MRC samples are presented in Table 5.1. Samples are divided into two groups, defined as those with chondritenormalised $\mathrm{La} / \mathrm{Sm}$ ratios $\left(\mathrm{La} / \mathrm{Sm}_{\mathrm{N}}\right.$ ) of $1.0-1.5$ (Group 1) and those with $1.8-3.0$ (Group 2; Table 5.1). Group 2 samples have significantly higher concentrations of highly incompatible elements compared to Group 1 samples (e.g. La, Nb, Ce; Table $5.1)$. 

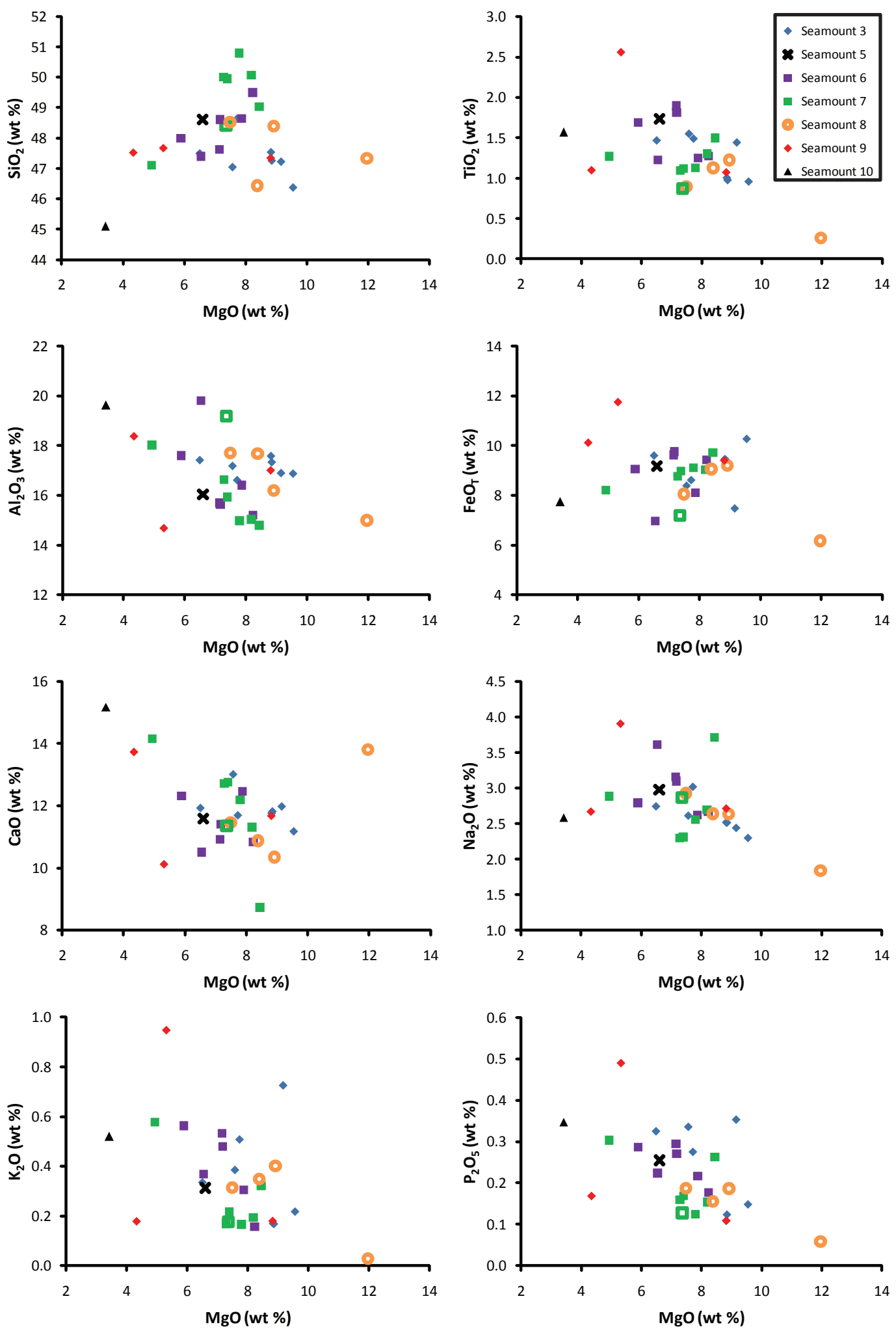

Figure 5.2. Bivariate MgO-major element diagrams for MRC dredge samples. 


\subsubsection{Bivariate $\mathrm{MgO}$-trace element diagrams}

Diagrams of trace element concentration versus $\mathrm{MgO}$ content are displayed in Figure 5.3. Group 1 samples define a cluster of points between 7 and 10 wt.\% MgO (except $\mathrm{B} 98 \mathrm{~B}=4.4$ wt.\% $\mathrm{MgO}$ ) with limited variation in and generally low $\mathrm{Rb}, \mathrm{La}$, $\mathrm{Nb}, \mathrm{Th}, \mathrm{Pb}$ and $\mathrm{Sr}$ contents. Group 2 samples display increasing $\mathrm{La}, \mathrm{Nb}$, and $\mathrm{Th}$ concentrations with decreasing MgO content. Group 1 and 2 samples together display poorly-defined negative and positive relationships between MgO content and $\mathrm{Pb}$ and $\mathrm{Sc}$ concentrations, respectively. Ni concentrations in MRC samples decrease rapidly between 7 and $10 \mathrm{wt} . \% \mathrm{MgO}$, and more gradually at lower $\mathrm{MgO}$ contents.

\subsubsection{Multielement and REE diagrams}

Primitive mantle-normalised multielement and rare earth element (REE) diagrams for MRC samples are displayed in Figures 5.4 and 5.5. MRC samples display a range of multielement patterns that generally plot between reference values for average E-MORB and OIB (Fig. 5.6). Individual samples display the following features: positive $\mathrm{Nb}$ and $\mathrm{Ta}$ anomalies; negative $\mathrm{K}$ and $\mathrm{Pb}$ anomalies; negative $\mathrm{U}$ anomalies for some samples; slight negative Ti anomalies (Fig. 5.4). Group 2 samples define significantly steeper lighter REE/medium REE (LREE/MREE) slopes and slightly higher medium REE/heavy REE (MREE/HREE) slopes than Group 1 samples (Fig. 5.5). Despite the near OIB-like trace element abundances for some samples, all MRC samples display significantly lower MREE/HREE ratios than typical OIB that are more comparable to E-MORB (Figs. 5.5, 5.6).

\subsection{DISCUSSION}

\subsubsection{Magmatic processes at the relic Macquarie spreading centre}

Sampling of discrete segments of mid-ocean ridges often reveals systematic variations in major element contents over a range of $\mathrm{MgO}$ content for the sample 

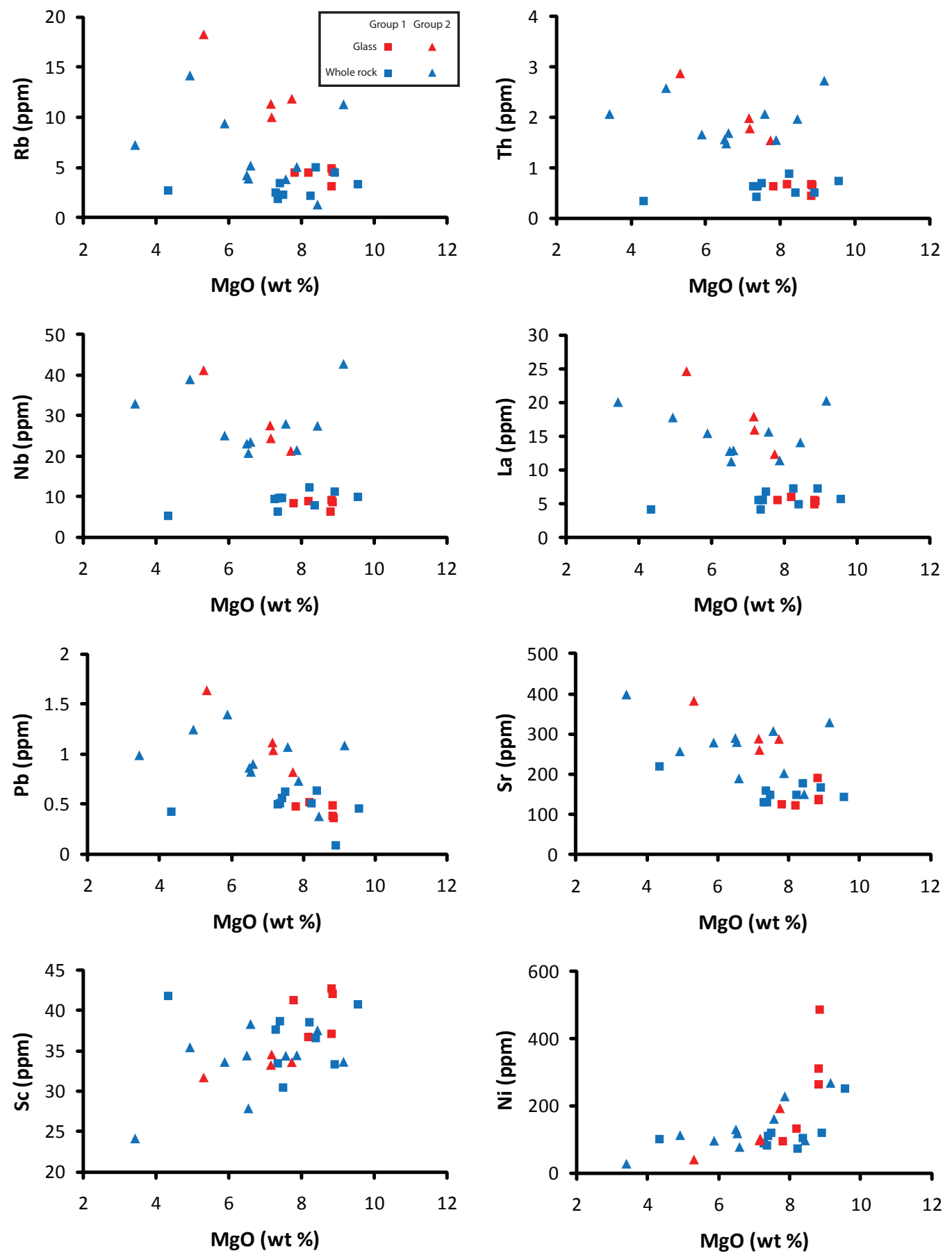

Figure 5.3. Bivariate $\mathrm{MgO}$-trace element diagrams. $\mathrm{MgO}$ content in wt \%. 

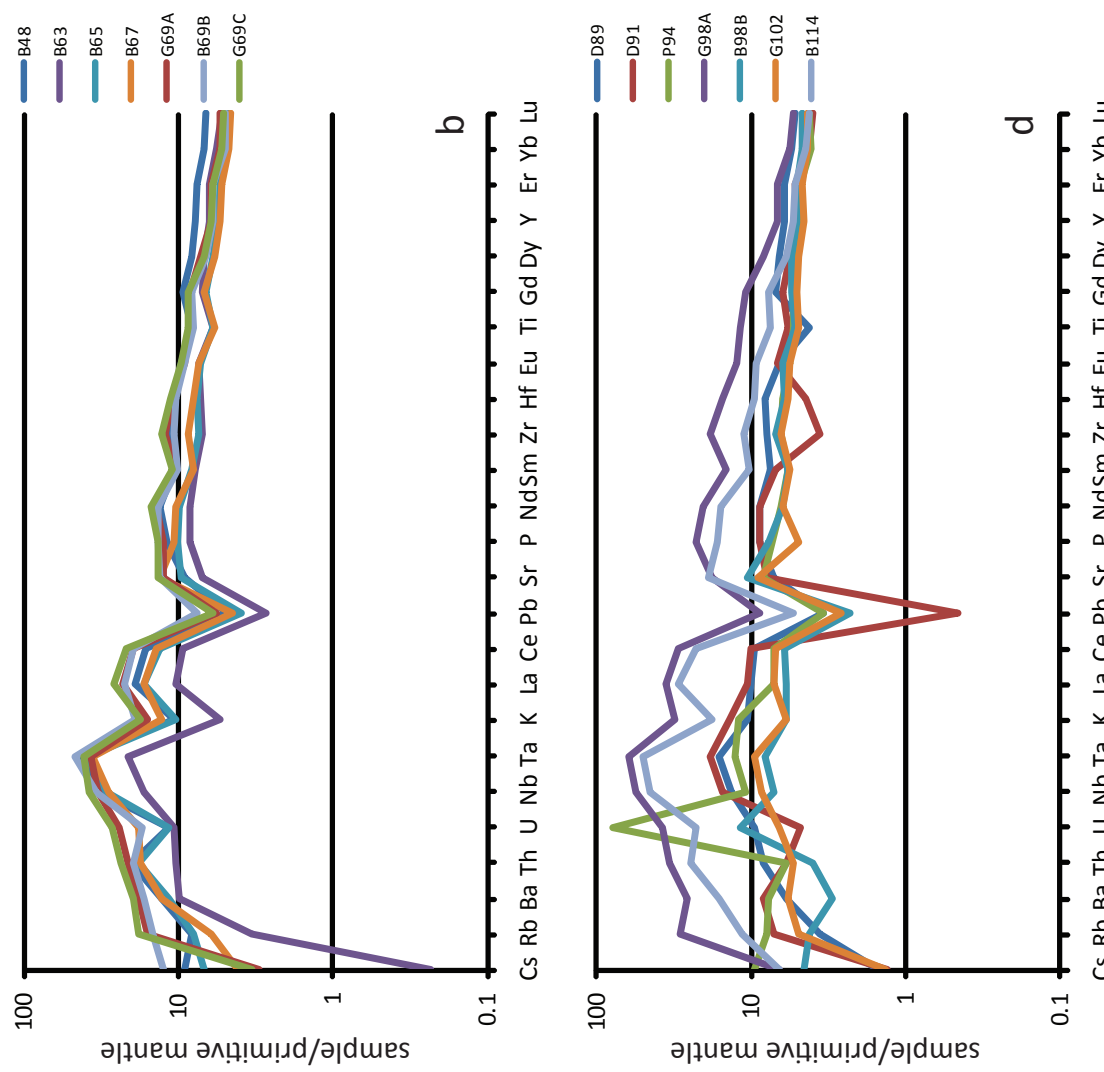

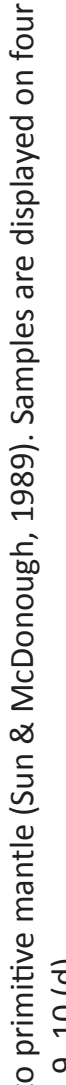
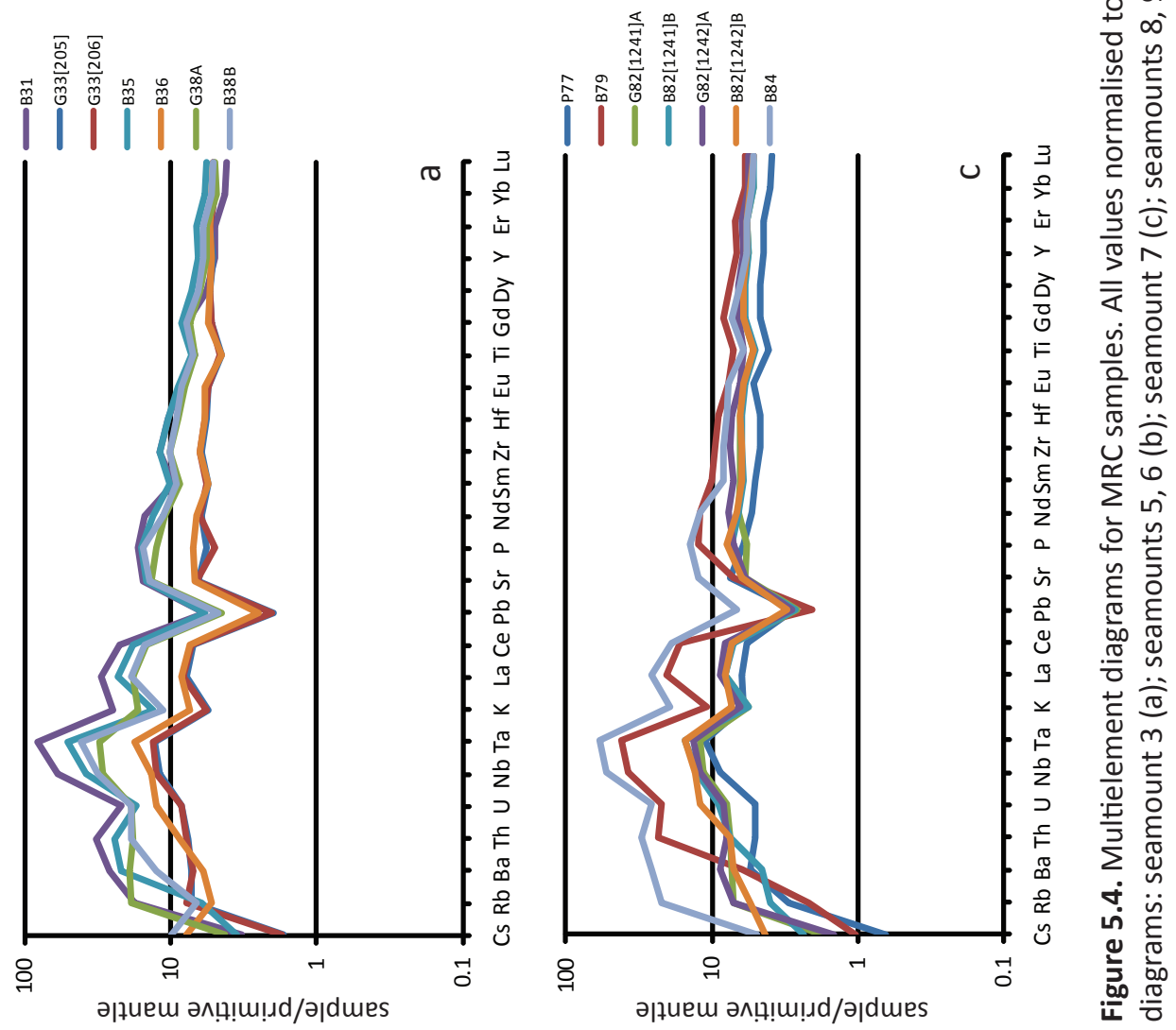

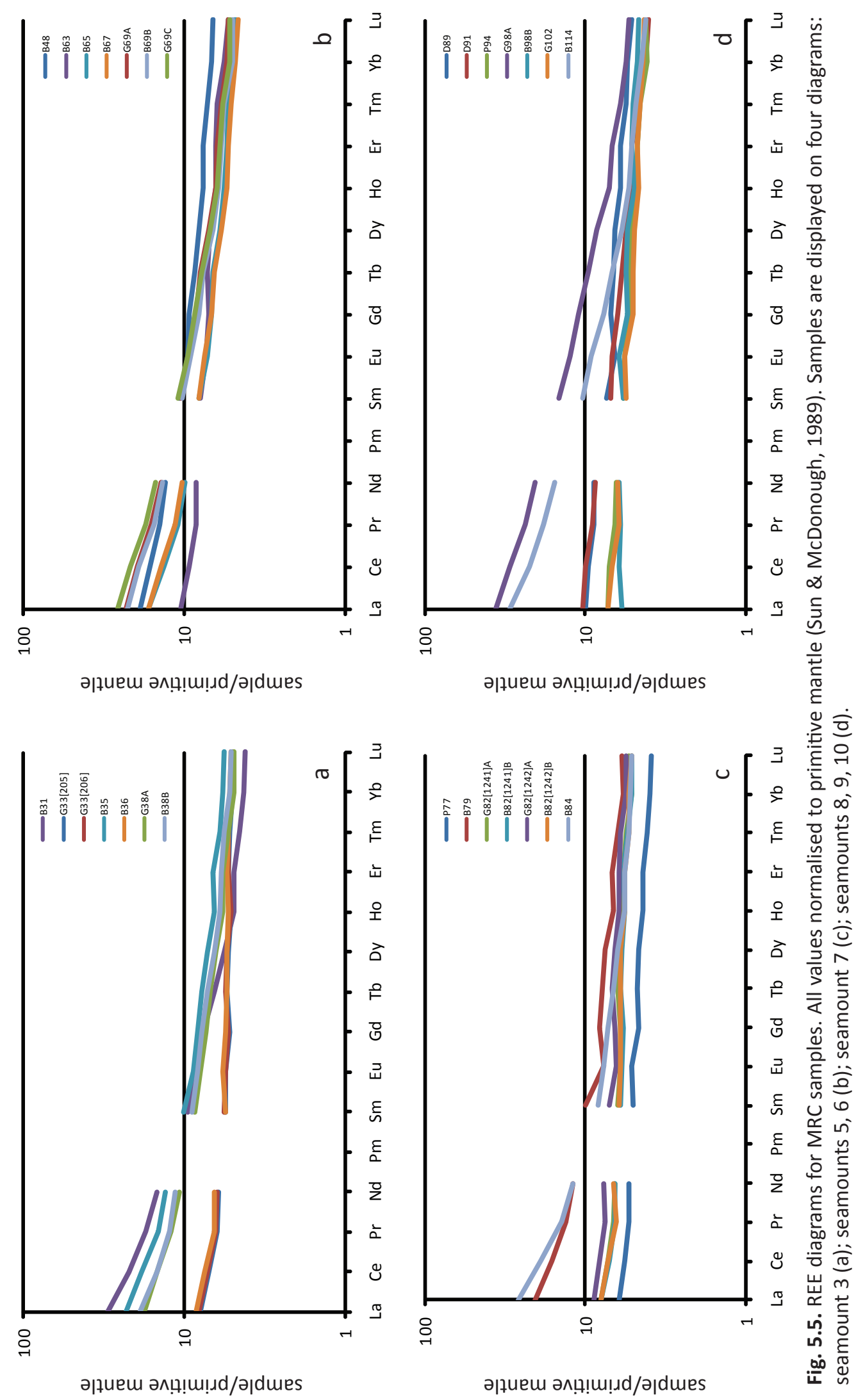

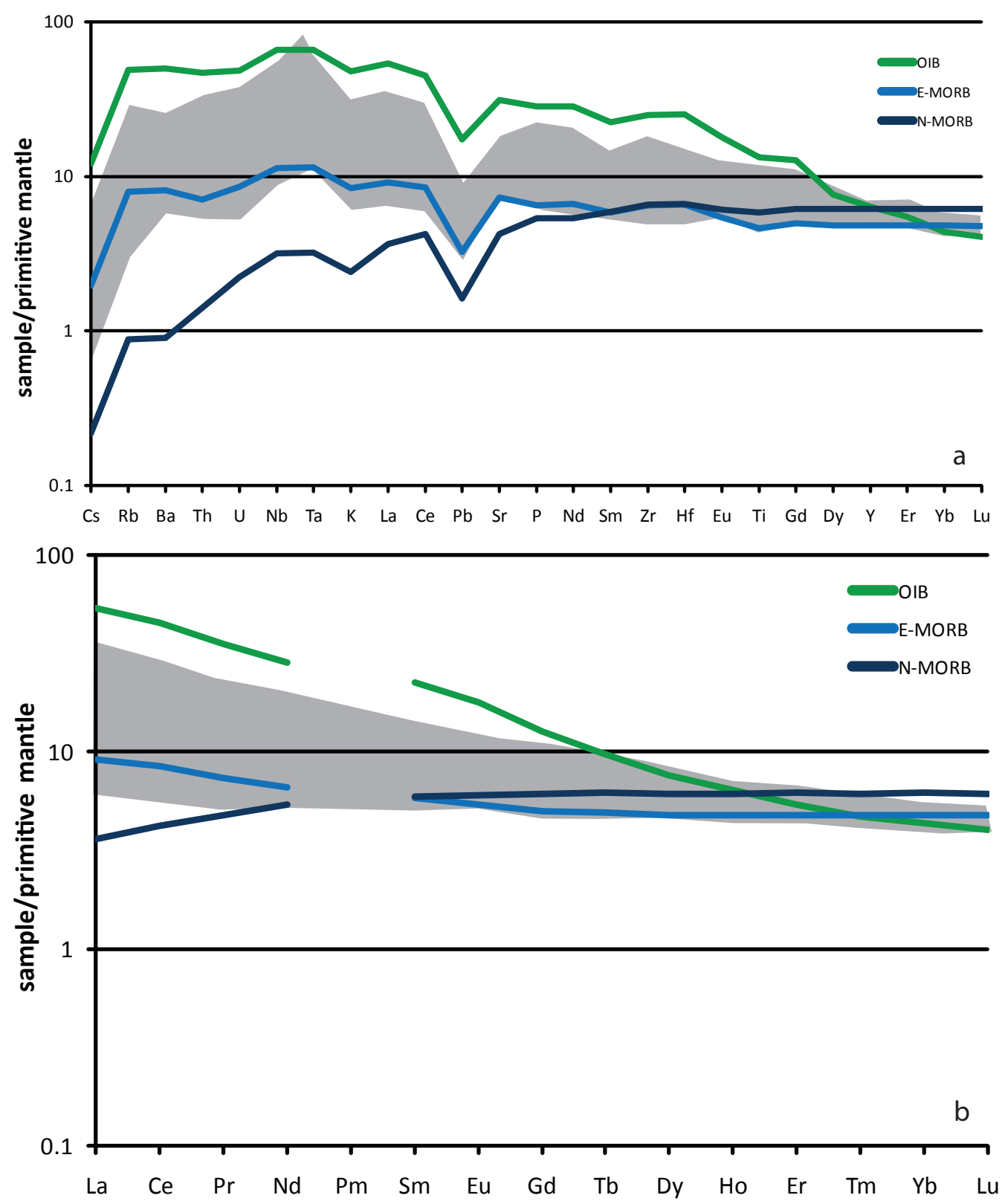

Figure 5.6. Multielement (a) and REE (b) diagrams showing compositional field for MRC samples (grey). Reference values for ocean island basalt (OIB), enriched mid-ocean ridge basalt (E-MORB) and normal mid-ocean ridge basalt (N-MORB) are from Sun \& McDonough (1989). All values normalised to primitive mantle (Sun \& McDonough, 1989). 
suite (e.g. Bender et al., 1978). Such relationships are explained by the eruption of basalts that have undergone variable degrees of fractional crystallization in a parental magma chamber (Grove \& Bryan, 1983). Major element contents do not display clear linear changes with $\mathrm{MgO}$ content for the suite of samples collected from the MRC (Fig. 5.2). To observe major element compositional trends that are not affected by the different mineral assemblages and abundances present in basaltic samples, bivariate diagrams for volcanic glass were investigated (Chapter 4). However, ranges in major element composition between glass samples with similar MgO content are also observed (Chapter 4, Fig. 4.4). Trace element concentrations also show considerable variation at a given $\mathrm{MgO}$ content (Fig. 5.3). The range in major and trace element compositions at a given $\mathrm{MgO}$ content indicates that MRC lavas derive from compositionally distinct parental magmas, which is not unexpected given the relatively sparse and discrete sampling over such a large area of the MRC. As such, the primary control on the incompatible trace element variability is related to source processes, be that variable degrees of partial melting or source heterogeneity. The MRC is considered to represent oceanic crust formed at the relic Macquarie spreading centre that has since been accreted along

the modern plate boundary (Chapter 3 ). The geochemical data presented here indicate that lavas originating from temporally and spatially distinct magma chambers have been juxtaposed at seamounts by transpressional relative plate motion along the MRC.

\subsubsection{Mantle processes at the relic Macquarie spreading centre}

MRC samples display a range in incompatible trace element-enrichments from EMORB to OIB-like levels (Fig. 5.6). The volcanic suite of Macquarie Island is also dominated by E-MORB to OIB-like trace element characteristics, which have been suggested to be the result of low degrees of partial melting during the waning stages of volcanism at the Australia-Pacific plate boundary south of New Zealand (Kamenetsky et al., 2000; Wertz, 2003). The variable levels of enrichment in Macquarie Island samples are proposed to be the result of different melting extents 
beneath the ridge (Wertz, 2003), and not due to assimilation during magma storage, as previously suggested by Kamenetsky et al. (2000). All samples from Macquarie Island that were analysed by Wertz (2003) are alkaline basalts, whereas submarine MRC samples range from alkaline to sub-alkaline basalts. The most enriched of the MRC samples (i.e. Group 2 samples) are alkaline or transitional basalts, although sub-alkaline basalts also display E-MORB signatures (Table 5.1).

Bivariate diagrams of incompatible trace element content versus Th content are plotted in Figure 5.7. Th is used in this plot because it is a fluid-immobile element and is therefore resistant to the effects of any potential seawater alteration of samples. MRC samples display strong positive linear arrays (Fig. 5.7), which can be generated by fractional crystallisation, partial melting or source heterogeneity.
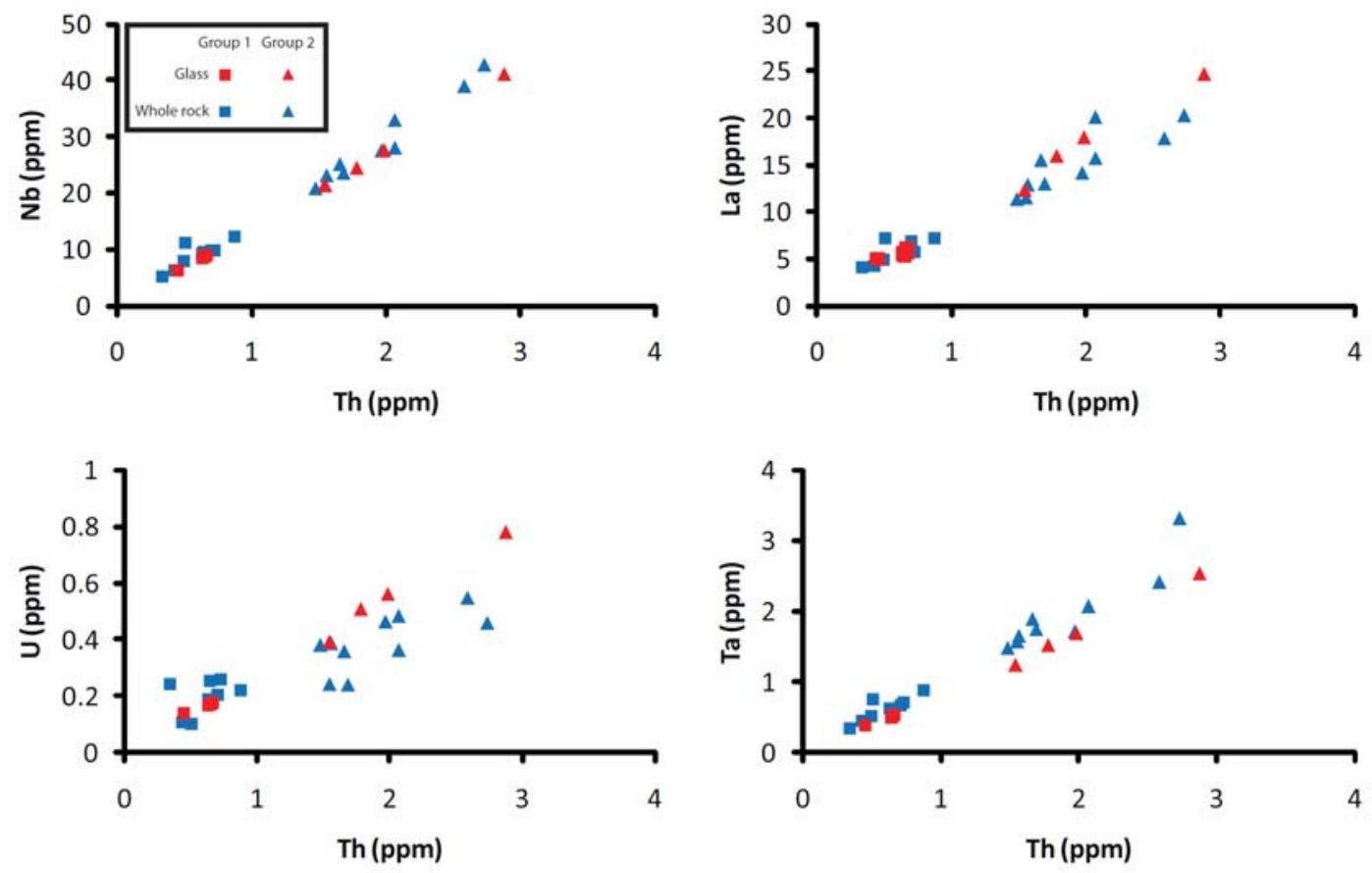

Figure 5.7. Bivariate diagrams of Th content versus other incompatible trace element contents.

The wide range in Th content at a given $\mathrm{MgO}$ content (Fig. 5.3) indicates the relationship is not controlled by the process of fractional crystallisation. Thus, the wide range in incompatible trace element variations (e.g. Th $=0.3$ to $3 \mathrm{ppm}$ ) are largely controlled by mantle source processes, i.e. the extent of partial melting and/or source heterogeneity. In order to identify the influence of the degree of partial melting on basalt chemistry, $\mathrm{Nb} / \mathrm{Zr}$ is plotted against $\mathrm{Nb}$ content in Figure 5.8. Higher $\mathrm{Nb} / \mathrm{Zr}$ indicates a greater enrichment in highly incompatible elements 
because $\mathrm{Nb}$ is more highly incompatible than $\mathrm{Zr}$ during partial melting. The steep trend observed for Group 1 samples with $\mathrm{Nb}$ contents of $0-12 \mathrm{ppm}$ can be explained by variable extents of partial melting. A common feature of these samples is their relatively high $\mathrm{MgO}$ contents (7.3 - 9.6 wt.\%), with the exception of sample $\mathrm{B} 98 \mathrm{~B}(\mathrm{MgO}=4.3 \mathrm{wt} . \%)$.

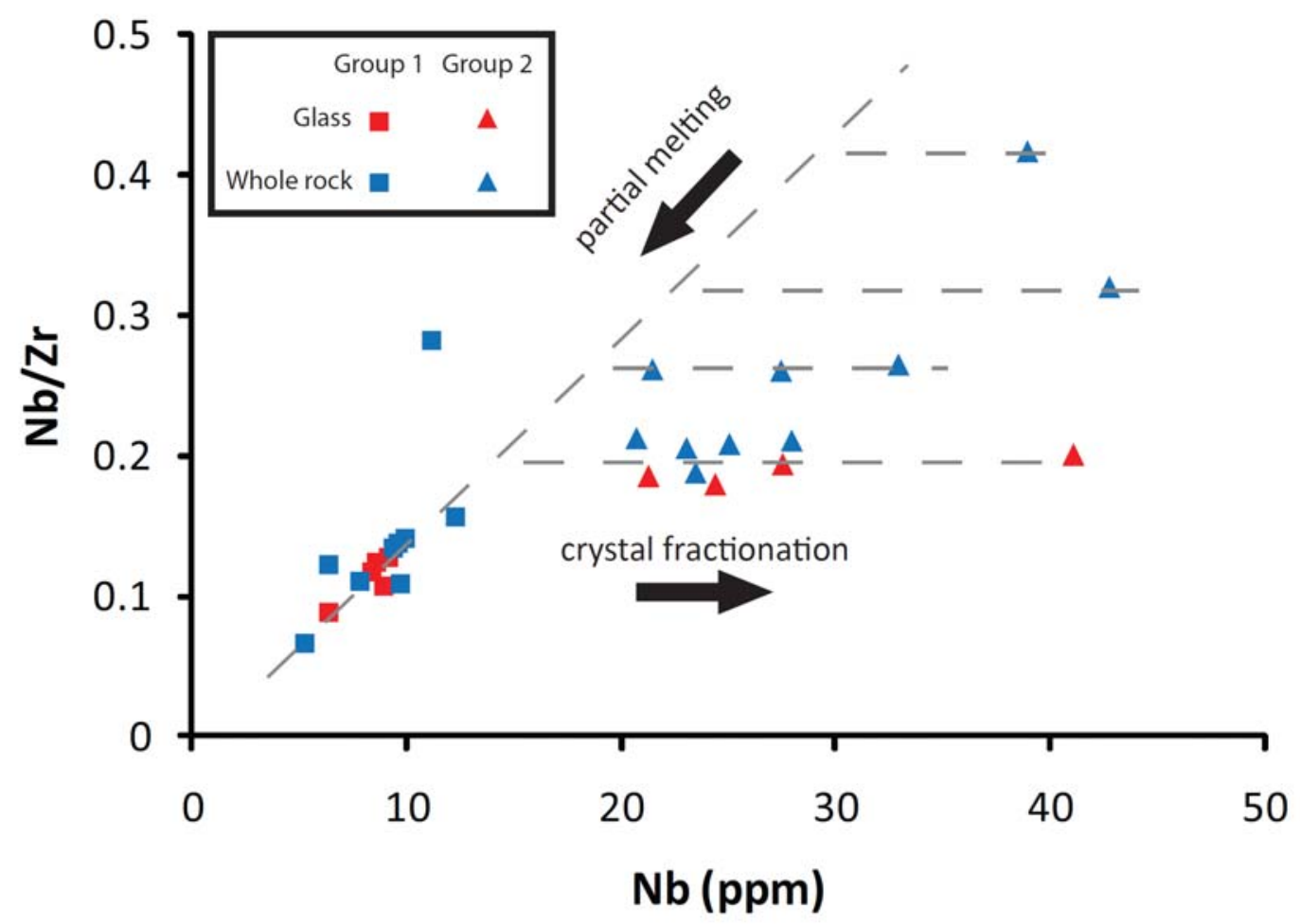

Figure 5.8. Plot of $\mathrm{Nb} / \mathrm{Zr}$ versus $\mathrm{Nb}$ content (ppm). The steep trend represents changes in basalt composition for Group 1 samples due to variable extents of partial melting (arrow indicates increasing degree of melting). Horizontal trends represent changes in composition for Group 2 samples due to crystal fractionation.

Between $\mathrm{Nb}$ contents of 20 and $45 \mathrm{ppm}$, Group 2 samples define horizontal trends or offsets from the linear array that is defined by Group 1 basalts (Fig. 5.8), indicative of changes in trace element chemistry due to the effects of fractional crystallization. This is consistent with lower MgO contents (3.4 - 7.9 wt.\%) for the samples that conform to this trend, with the exception of samples $\mathrm{B} 31$ ( $\mathrm{MgO}=9.2$ wt.\%) and B79 (MgO = 8.4 wt.\%). Furthermore, Group 2 samples display fractional crystallisation trends for highly incompatible elements La and $\mathrm{Nb}$ when plotted against MgO content (Fig. 5.3). 
Semi-quantitative modelling of partial melting processes is presented in Figure 5.9. Modelling is based on point-average, non-modal, fractional melting (Shaw, 1970), using the distribution coefficients of McKenzie and O'Nions (1991). Modelled partial melts and observed MRC basalt compositions are presented as trace element ratios given that effects of fractional crystallisation are not as significant on incompatible trace element ratios as they are on concentrations. Melting curves are shown for spinel and garnet Iherzolites with primitive mantle compositions (values from Taylor \& McLennan, 1985; Fig. 5.9). A mixing array between a low degree (0.5\%) garnetfacies melt and higher degree (5\%) spinel-facies melt are also plotted.

While the modelling is only indicative, it highlights a number of observations. Firstly, melting of a depleted mantle source (not shown) cannot reproduce the observed incompatible element ratios (or concentrations) in MRC samples without entailing extremely low degrees of partial melting $(<<0.5 \%)$. Rather, MRC basalts appear to represent variable degrees of partial melting of an enriched (primitive-mantle-like composition or more enriched composition) spinel Iherzolite (Fig. 5.9a). Group 1 MRC basalts correspond to larger degrees of partial melting (generally $20-2 \%$ ) compared to Group 2 basalts ( $<2 \%$; Fig. 5.9 a). It is also evident that Group 2 basalts have slightly higher MREE/HREE values (Fig. 5.9a), as has been previously observed (Fig. 5.4). To assess whether this is due to variable melting conditions, Dy/Yb versus $\mathrm{La} / \mathrm{Sm}$ is plotted in Figure 5.9b; large changes in $\mathrm{Dy} / \mathrm{Yb}$ with varying melt fraction for garnet melts allow discrimination between melting in the spinel and garnet stability fields (Thirlwall et al., 1994; Baker et al., 1996). Figure 5.9b distinguishes Group 1 from Group 2 basalts based on partial melting degrees of $20-5 \%$ and $2-1 \%$, respectively. However, observed MRC compositions do not correlate perfectly with modelled spinel therzolite melt compositions (Fig. 5.9b). In particular, Group 2 basalts are offset to $\mathrm{Dy} / \mathrm{Yb}$ values that more closely reflect the modelled compositions of a mix between spinel and garnet lherzolite partial melts. The correspondence between Group 2 samples and the garnet melt-spinel melt mixing trend indicates that the higher MREE/HREE values in these samples are likely to be the result of addition of small amounts of partial melts from garnet lherzolite to the predominantly spinel-facies melts (Fig. 5.9b). 


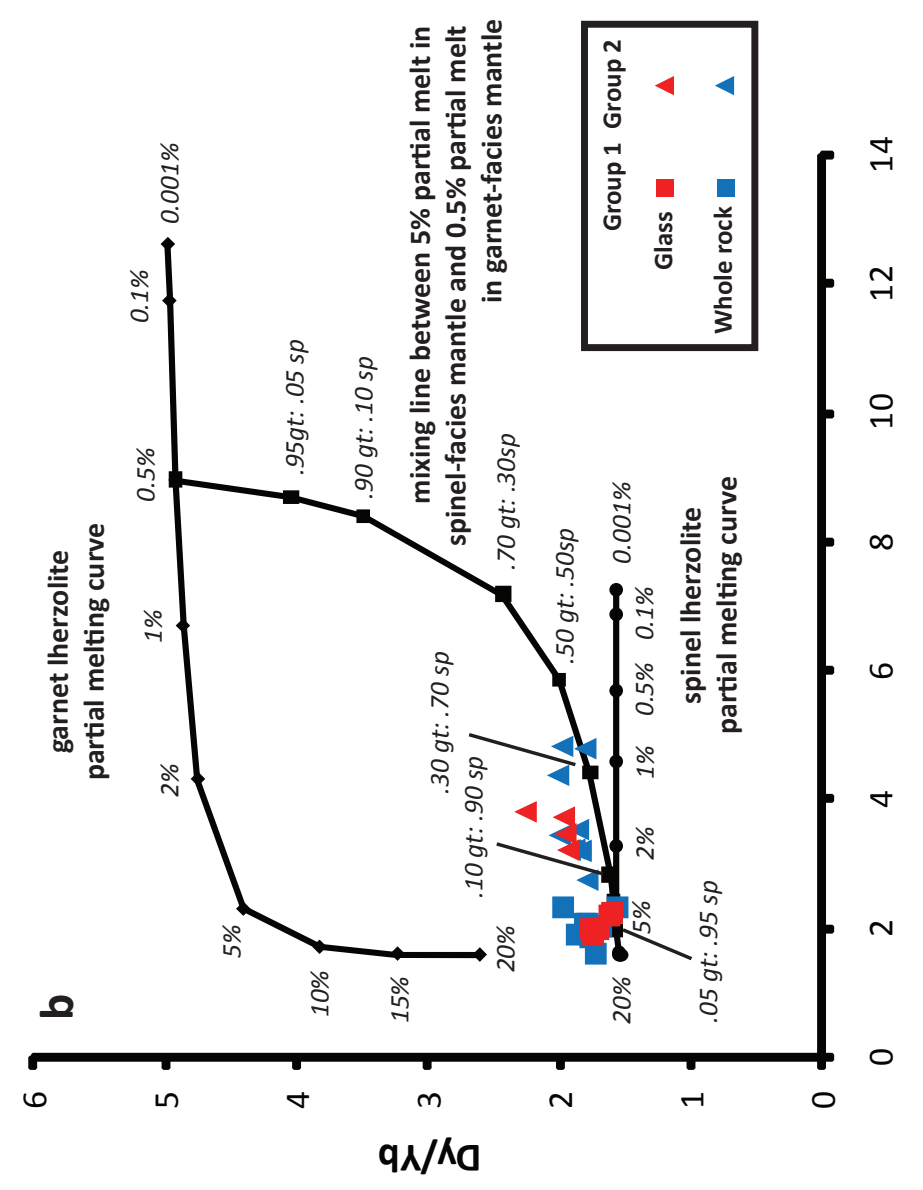

ब्ष्य

흥

후웡

है

주에

흔

은

항 즌 旁

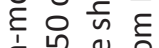

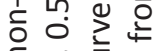

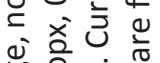

है

త

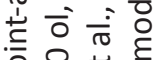

흥웅 농

就䨌

ฆํㅡㄹ 을

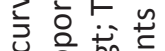

bo 는 눈

黄宁埒

E.

ज证

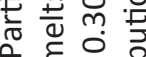

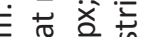

ज

근 웅

$m \stackrel{0}{=}$

ปั๊ 응ํํ.

ว

음 웍 올

둥 동

히응 인

은 응 인

ฟิ กั亡

$\cong 0 . \frac{1}{\square}$

जै

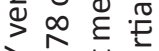

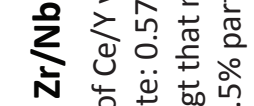

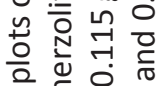

음히응

는

¿ थे

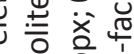

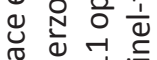

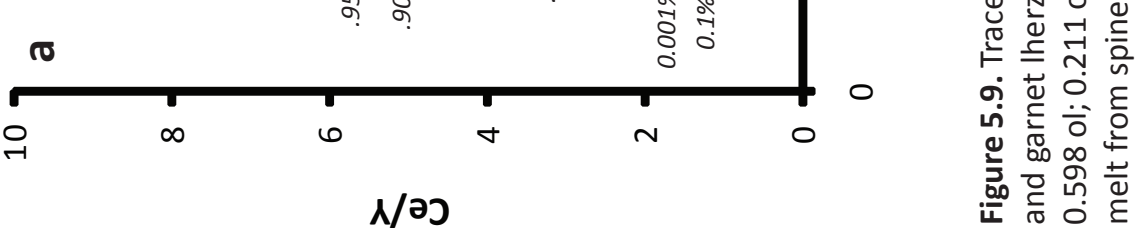


Thus, the Group 2 basalts were apparently generated by a lower degree of partial melting relative to Group 1 basalts, as well as with some contribution of low degree garnet Iherzolite partial melts, to account for their greater incompatible element concentrations (Table 5.1). These magmas subsequently underwent variable but significant crystal fractionation prior to their eruption, producing lower MgO contents and higher incompatible trace element concentrations (Table 5.1; Fig. 5.3). The lower degrees of partial melting may be related to a decrease in spreading rates at the relic Macquarie spreading centre. The link between seafloor spreading, melting and crystallisation processes can be explained by a model whereby the ascent of Group 2 melts was retarded due to a decrease in the amount of extension at the ridge, thus resulting in more extensive crystal fractionation prior to eruption of these low degree partial melts. Such a model may apply to the waning stages of mid-ocean ridge volcanism at the relic Macquarie spreading centre when spreading rates were ultraslow (Wood et al., 1996). Alternatively, Group 2 basalts may have been generated during post-spreading volcanism at the relic Macquarie spreading centre when seafloor spreading had ceased. This hypothesis is considered further below.

\subsubsection{Post-spreading volcanism at the MRC}

Several studies have observed that lavas with ages younger than the date for the cessation of spreading on extinct mid-ocean ridges are significantly more alkaline and incompatible element-enriched than the MORB originating from the preceding spreading regime. Magmatism that continued subsequent to the termination of spreading has been proposed to have occurred at the Guadalupe Ridge (Batiza, 1977; Batiza \& Vanko, 1985; Davis et al., 1995), the Mathematician Ridge (Bohrson \& Reid, 1995), Davidson Seamount (Clague et al., 2009b; Castillo et al., 2010) and the Phoenix Ridge (Haase et al., 2011). Magmatism may continue subsequent to the cessation of spreading at a mid-ocean ridge due to the retention of some preexisting melt from the preceding volcanism beneath the relic ridge axis (Castillo et al., 2010). The melt remains close to its solidus temperature and, due to its 
buoyancy relative to the surrounding mantle, ensures continued adiabatic decompression melting below the extinct ridge axis, albeit at a very low degree (Castillo et al., 2010). Fertile and easily fusible portions of the sub-ridge mantle (i.e. geochemically enriched heterogeneities) are preferentially tapped over more depleted sources at the low melt fractions due to their higher alkali element contents (Hirschmann, 2000).

The MRC coincides with the location of a recently extinct mid-ocean ridge and is composed (at least partially) of enriched and alkaline basalts. The incompatible element-enrichment of volcanic rocks exposed on Macquarie Island has been attributed to low rates of seafloor spreading during the last stages of relative plate separation at the MRC, which induced low degrees of partial melting (Kamenetsky et al., 2000; Wertz, 2003). However, even at the slowest spreading mid-ocean ridges, OIB-like enrichments in incompatible elements have not been observed (e.g., Gakkel ridge; Mühe et al., 1997). REE patterns of MRC basalts are compared to lavas of similar major element composition from the Gakkel Ridge, Phoenix Ridge and Davidson Seamount in Figure 5.10. The trace element chemistry of Group 1 basalts resembles that of E-MORB from the Gakkel Ridge, whereas Group 2 basalts are more comparable to those formed by post-spreading magmatism at the Phoenix Ridge and Davidson Seamount. Sample B69B from seamount 6 is nearly identical to sample 55DR-05gl from the Phoenix Ridge (Haase et al., 2011), and sample G98A closely resembles alkali basalt sample T140R16 from Davidson Seamount (Castillo et al., 2010; Fig. 5.10).

In light of this it seems plausible that the Group 2 basalts (and the Macquarie Island alkaline basalts with OIB-like signatures analysed by Wertz, 2003) were generated by post-spreading magmatism at the relic Macquarie spreading centre. Remnant heat retained in trapped melt from previous mid-ocean ridge volcanism induced buoyant ascent of the mantle relative to the surrounding asthenosphere (Castillo et al., 2010). Low degrees of partial melting preferentially tapped enriched spinel and garnet Iherzolite sources present in the sub-ridge mantle. The relatively low MgO contents and fractionated major and trace element concentrations in Group 2 samples indicate that they experienced significant crystal fractionation before 
eruption, due to the absence of an active axial rift zone following the cessation of spreading, which retarded the ascent rate of the MRC magmas. This is consistent with the dominance of differentiated alkalic post-spreading lavas from Davidson Seamount (Castillo et al., 2010) and the Phoenix Ridge (Haase et al., 2011), and may be a common feature of post-spreading lavas. Isotopic dating of MRC samples and comparison with tectonic models for the timing of the cessation of spreading along the Australia-Pacific plate boundary south of New Zealand should enable further evaluation of this proposed model for the origin of MRC basalts.

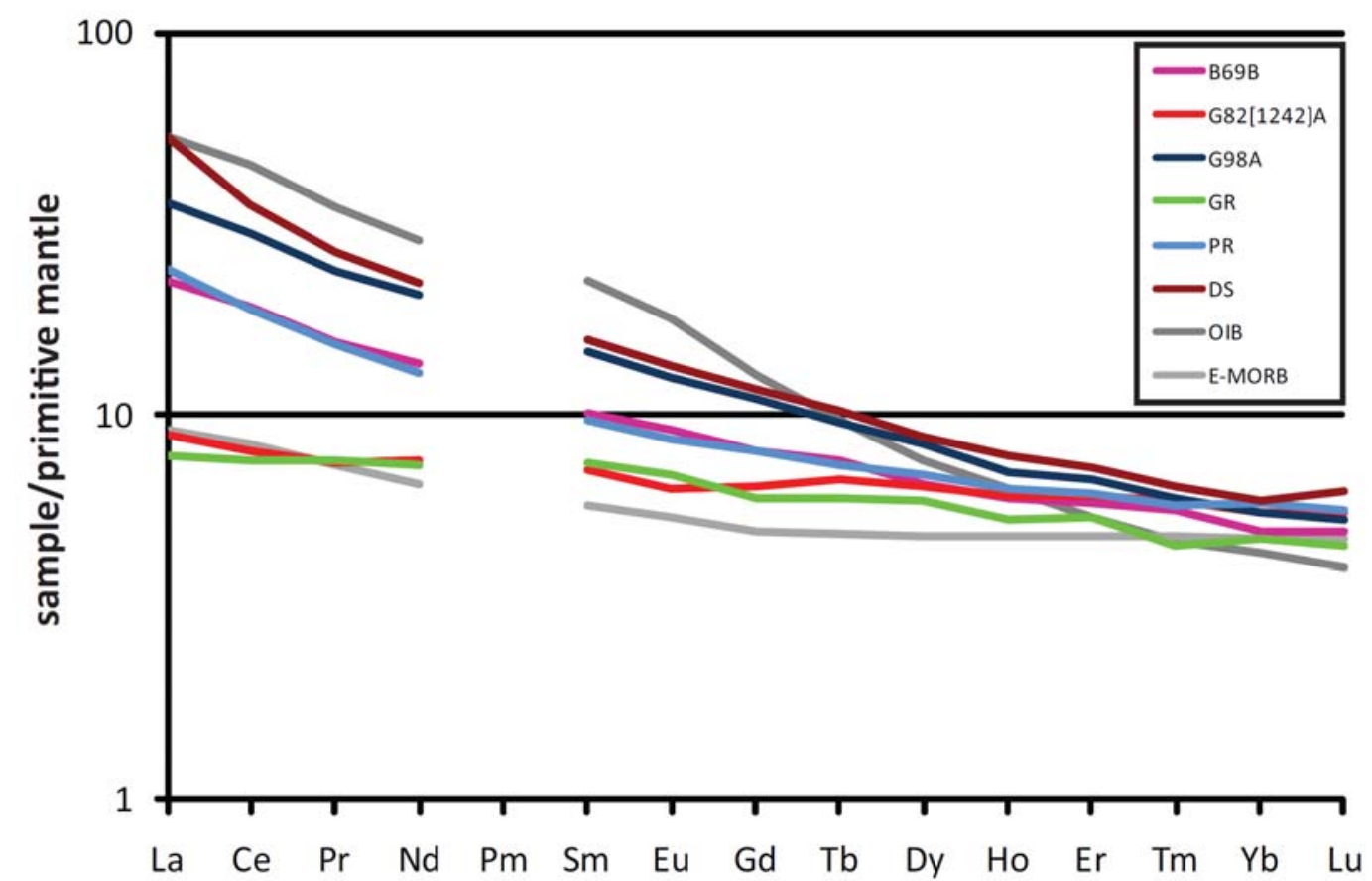

Figure 5.10. REE diagram showing comparison of MRC samples and basalts from other mid-ocean ridges: Gakkel Ridge NGR sample 1 (GR, from Muhe et al., 1993); Phoenix Ridge sample 55DR-05gl (PR, from Haase et al., 2011); Davidson seamount sample T140R16 (DS, from Castillo et al., 2010). Values for OIB and E-MORB from Sun and McDonough (1989). All values normalised to primitive mantle (Sun \& McDounough, 1989).

Post-spreading magmatism has been attributed to the creation of bathymetric highs along fossil ridges (Castillo et al., 2010; Haase et al., 2011). It is well-accepted that cumulative transpressional relative plate motion along the Australia-Pacific plate boundary south of New Zealand has created the relief of the MRC (Massell et al., 2000; Meckel et al., 2005). Major and trace element systematics indicate that individual MRC seamounts formed through tectonic accretion of lavas derived from spatially and temporally distinct magma chambers. An alternative theory is that the 
seamounts that comprise the rugged bathymetry of the MRC also partly represent volcanoes constructed during post-spreading magmatism at the MRC. Morphological similarities between some MRC seamounts and Davidson Seamount of offshore California argue for a similar origin (Clague et al., 2009b; see Chapter 3 for description of MRC seamount morphology). Relic conduits and new strike-slip faults may have provided pathways for the ascent of post-spreading magmas as the Australia-Pacific plate boundary transitioned into transpressional motion. The pervasive enrichment in incompatible elements for MRC basalts may therefore have been biased by the strategy used in collection of samples (i.e. only bathymetric elevations were dredged). However, samples were acquired from a range of seamounts with variable morphologies, most of which do not resemble volcanoes (Chapter 3).

If volcanism proceeded during the onset of transpressional motion, explosive submarine eruptions may have been promoted by a shallowing of the eruption depth (i.e. seafloor depth) as oceanic crust was accreted, uplifted and exhumed along the plate boundary (Chapter 3). Magmatic fragmentation of highly vesicular glass shards with alkaline and enriched compositions in volcaniclastic breccia from seamount 9 and Macquarie Island has been suggested to have been aided by a shoaling of the seafloor (Daczko et al., 2009; Portner et al., 2009), in addition to magmatic volatile concentration (Chapter 4). Regardless of the origin of the seamounts' elevation and morphology, they have been modified by strike-slip and dip-slip faulting since their volcanic construction (Chapter 3 ).

\subsubsection{Mantle heterogeneity beneath the relic Macquarie spreading centre}

The presence of enriched basaltic lavas has been reported from numerous regions of the global mid-ocean ridge system. Such regions include the ultraslow spreading Gakkel Ridge (Mühe et al., 1993; 1997), the fast-spreading East Pacific Rise (EPR; Niu et al., 2002; Waters et al., 2011), the Kane Fracture Zone of the Mid-Atlantic Ridge (MAR; Donnelly et al., 2004) and several fossil spreading ridges in the Pacific Ocean (Castillo et al., 2010; Haase et al., 2011). These localities are distal from mantle 
plumes, represent a range of seafloor spreading rates and, in the case of the EPR and MAR, are proximal to coexisting N-MORB lavas. Thus, E-MORB are generated at a range of volcano-tectonic settings and their origin can be independent of interaction with mantle plume material.

Two main models have been proposed to explain the origin of the enriched component in these settings: (1) a small portion of the mantle is metasomatised by low degree melts from subducted eclogitic slab (Donnelly et al., 2004), sub-oceanic lithospheric mantle (Niu et al., 2002) or subcontinental lithosphere (Galer \& O'Nions, 1986) and melted to a large degree at the mid-ocean ridge; (2) low degree partial melting of garnet pyroxenite introduced to the sub-ridge environment via the subduction and recycling of oceanic crust (Allègre \& Turcotte, 1986; Lundstrom et al., 1999; Waters et al., 2011). In addition to the presence and partial melting of an enriched source, E-MORB melts must also remain relatively isolated from the more volumetric depleted upper mantle prior to their eruption to avoid dilution by more depleted melts (Waters et al., 2011). Such a scenario is associated with regions of low magmatic activity (Waters et al., 2011) and slow seafloor spreading rates (Mühe et al., 1997; Shaw et al., 2010) where mixing with more depleted melts is inhibited.

The E-MORB to OIB-like levels of incompatible trace element enrichment in MRC basalts require the presence of a geochemically enriched component in the mantle below the relic Macquarie spreading centre. MRC samples display relatively constant MREE/HREE ratios (Fig. 5.6), which suggests minimal presence of garnet in the source of the basalts (Hirschmann \& Stolper, 1996) and implies that pyroxenitic veins probably did not form the enriched components of the mantle beneath the relic Macquarie spreading centre. $\mathrm{Nd}-\mathrm{Sr}-\mathrm{Pb}$ isotope compositions of basaltic glass from Macquarie Island trend from Pacific MORB to HIMU (high- $\mu$, see Zindler \& Hart, 1986) compositions (Kamenetsky et al., 2000, their Figure 7). However, differences between Balleny Island and MRC basalt major element compositions and HREE contents indicate that MRC basalts are not the melting products of the Balleny plume (Lanyon et al., 1993; Kamenetsky et al., 2000). Thus, enriched spinelfacies Iherzolite ( \pm addition of low degree partial melts of garnet Iherzolite) was 
most likely to have been the enriched component beneath the relic Macquarie spreading centre (Haase et al., 2011). The lack of a significant garnet or plume signature in MRC basalts (Figs. 5.4, 5.5), their similarity to lavas from the Phoenix Ridge (Fig. 5.10) and results from semi-quantitative modelling (Fig. 5.9) provide the basis for this conclusion.

The identification of E-MORB to OIB-like characteristics in all volcanic and hypabyssal samples analysed in this study reveal that geochemically enriched components must have been present over a latitudinal distance of $c a .1,200 \mathrm{~km}$ beneath the relic Macquarie spreading centre. For example, sample B31 displays the same degree of enrichment in highly incompatible elements as sample G98A; the two samples are located more than 1,000 km from each other. The preservation of distinct compositions in closely-spaced samples on Macquarie Island suggests that the mantle was heterogeneous on a small-scale (Kamenetsky et al., 2000). We show that the heterogeneities, though small, were present along the length of the relic Macquarie spreading centre. The eruption of enriched, alkalic lavas at numerous fossil ridges in the eastern Pacific Ocean has led to the theory that much of the eastern Pacific upper mantle is compositionally heterogeneous. When combined with this study, it appears the Pacific upper mantle may be heterogeneous on an even larger (ocean-wide) scale.

\subsection{CONCLUSIONS}

1. The MRC is composed of alkaline to sub-alkaline basaltic lavas, volcaniclastic breccias, diabase and gabbro. Volcanic products originated from spatially distinct parental magma sources during seafloor spreading and have been juxtaposed at individual seamounts along the modern transpressional Australia-Pacific plate boundary.

2. All MRC basalts display E-MORB to OIB-like enrichments of incompatible trace elements and were generated by low degrees of partial melting beneath the relic Macquarie spreading ridge. Samples are divided into Group 1 samples ( $\mathrm{La} / \mathrm{Sm}_{N} 1.0-$ 
1.5, high-MgO, transitional to sub-alkaline) and Group 2 samples ( $\mathrm{La} / \mathrm{Sm}_{\mathrm{N}} 1.8-3.0$, low-MgO, alkaline to transitional).

3. Group 1 basalts were generated by low degrees of partial melting of an enriched spinel Iherzolite; Group 2 basalts were generated by lower degrees of partial melting of an enriched spinel Iherzolite mixed with small amounts of low degree partial melts from garnet Iherzolite. Group 2 basalts underwent variable and significant degrees of fractional crystallisation that produced the evolved major and trace element concentrations observed in the samples.

4. The relationship between high degrees of enrichment and fractional crystallization in Group 2 basalts indicates that the lowest degree partial melts generated at the relic Macquarie spreading centre experienced a stalled ascent prior to eruption, whereas Group 1 basalts retain more primitive compositions due to more efficient magma ascent rates.

5. Group 1 basalts were generated during the waning stages of seafloor spreading at the relic Macquarie spreading centre; Group 2 basalts were generated by postspreading magmatism at the MRC. Remnant heat from previous seafloor spreading induced buoyant ascent of the sub-ridge mantle and enriched heterogeneities were preferentially tapped by the ensuing low melt fractions after the cessation of spreading at the plate boundary.

6. The mantle beneath the relic Macquarie spreading centre was enriched on a regional scale to account for E-MORB to OIB-like enrichments in highly incompatible elements sampled along the length of the MRC. This extends the presence of a chemically heterogeneous Pacific upper mantle to an ocean-wide scale. 


\section{CHAPTER 6:}

SYNTHESIS

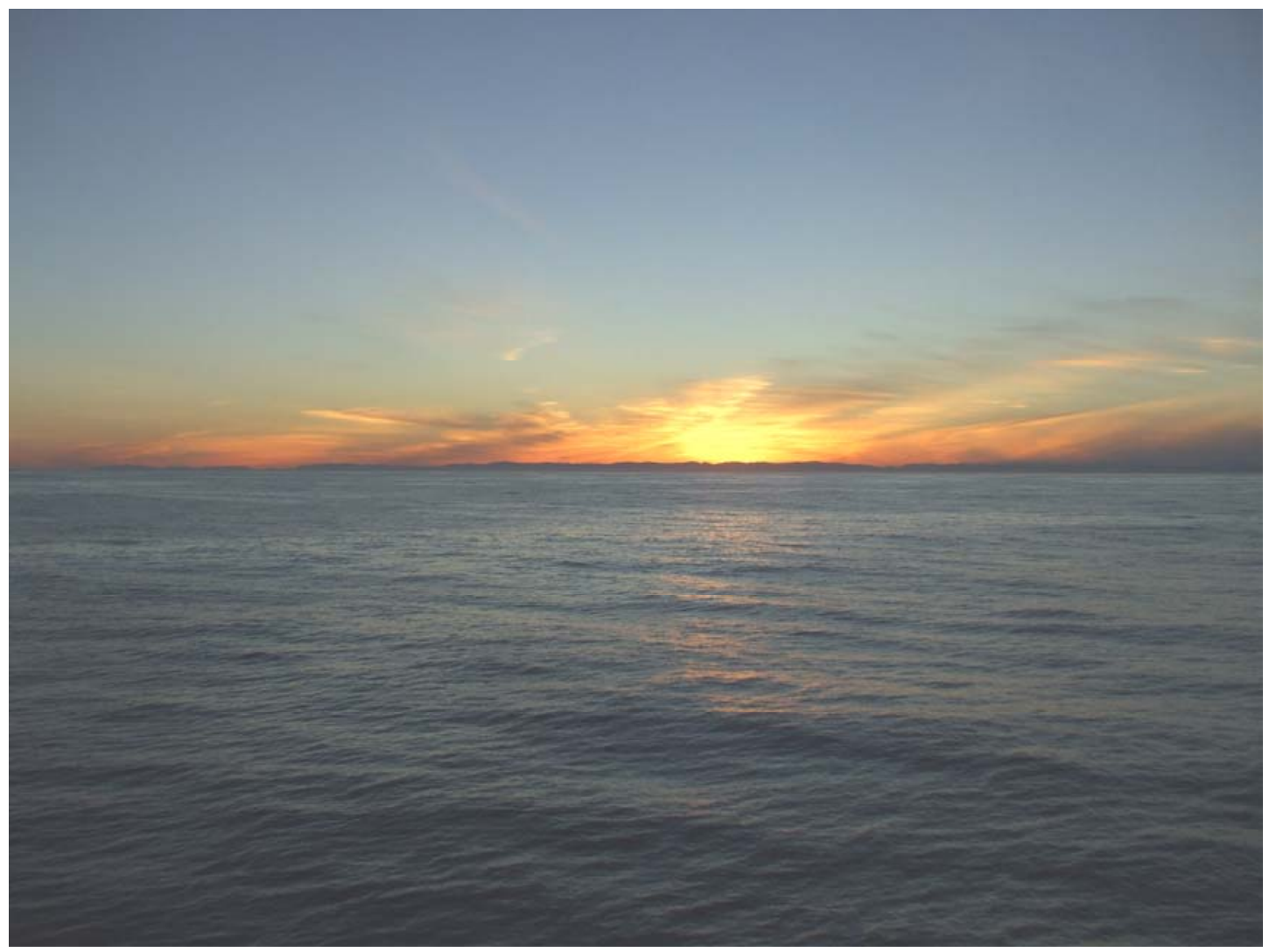

Plate 7. The sun sets over the Southern Ocean. 


\subsection{SUMMARY MODEL}

This study has presented new multibeam, photographic, petrologic and geochemical data acquired from Macquarie Ridge Complex (MRC) seamounts. When combined, the results offer the most complete and detailed model to date for the volcano-tectonic evolution of the Australia-Pacific plate boundary south of New Zealand, which is presented in Figure 6.1 and outlined below.

1. Mid-ocean ridge volcanism at the relic Macquarie spreading centre involved the eruption of alkaline to sub-alkaline basaltic lava during the waning stages of magmatism at the slow to ultraslow-spreading ridge (ca. $10-6 \mathrm{Ma})$. Low degree partial melts of an enriched spinel Iherzolite source were erupted as sub-alkaline to transitional E-MORB. The low magmatic activity ensured that these fertile portions of the chemically heterogeneous mantle below the ridge were preferentially tapped and avoided mixing with melts from the ambient depleted upper mantle. The chemically enriched melts rose efficiently and were erupted as effusive lava flows on the seafloor or were granulated on contact with seawater due to coolingcontraction fragmentation and deposited as hyaloclasts in volcaniclastic breccias.

2. Buoyant ascent and adiabatic decompression melting of the mantle beneath the MRC continued after the cessation of seafloor spreading at the Australia-Pacific plate boundary $(c a .5 \mathrm{Ma}$ ) due to the retention of heat in remnant melt from prior mid-ocean ridge magmatism. Low degree partial melts of enriched spinel lherzolite were mixed with small amounts of low degree garnet lherzolite partial melts beneath the fossil ridge axis. The melts were subsequently erupted as alkaline to transitional basalts with E-MORB to OIB-like trace element characteristics during post-spreading volcanism at the MRC. Melt ascent was presumably stalled due to the absence of an axial rift zone at the ridge, and subsequently underwent crystal fractionation and volatile exsolution prior to eruption. The combination of (i) high volatile contents in the enriched and alkaline melts, (ii) further volatile concentration due to fractional crystallisation during the stalled magma ascent, and (iii) a potential shoaling of eruption depth due to the onset of transpressional 


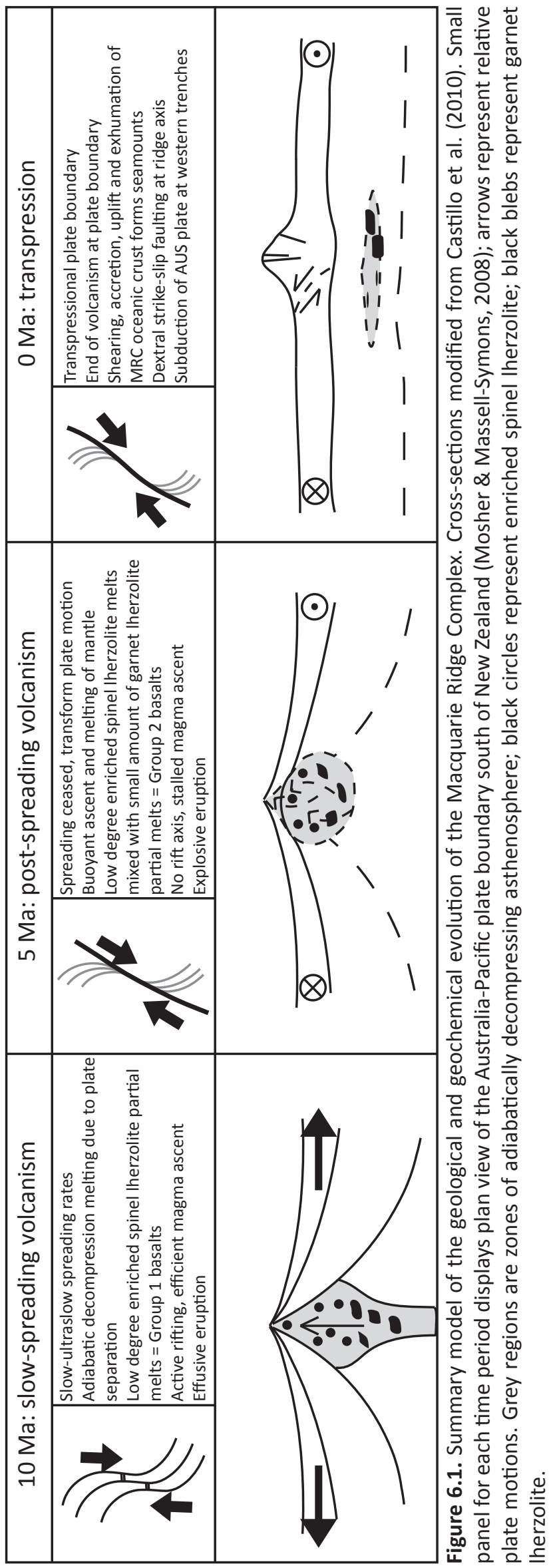


relative plate motion induced explosive eruption at discrete sites of volcanism along the fossil ridge.

3. Oceanic crust formed at the relic Macquarie spreading centre has been sheared, accreted, and exhumed as a result of transpression along the Australia-Pacific plate boundary south of New Zealand since ca. $6 \mathrm{Ma}$, and comprises the modern ridge substrate. Transform faulting has juxtaposed lavas that were derived from distinct magma chambers at individual seamount locations. Seamounts are aligned parallel to the plate boundary and elevated above the surrounding seafloor of the MRC as a result of discrete strike-slip and dip-slip faulting of the ridge axis. Three guyot-type seamounts have broad plateaux that were formed by wave (and current) erosion when their summits were at or near sea-level due to uplift of the ridge. Subsequent subsidence due to extension associated with the step-over fault pattern of the transform plate boundary can account for the present depth of the summits.

\subsection{SUGGESTIONS FOR FURTHER WORK}

This thesis has presented a detailed and diverse geological dataset for ten seamounts of the MRC. The results and ideas presented in this thesis offer avenues for future study of the region:

1. The MRC remains a relatively understudied region of the seafloor. The MRC represents a suite of MORB rocks that has not yet been added to the global MORB database but may offer insight into the mantle sources and processes beneath slow-spreading and extinct mid-ocean ridges. Moreover, the MRC comprises two of the youngest subduction zones on Earth where young oceanic crust is being subducted (Puysegur Trench and Hjort Trench). The significance of the MRC to global plate tectonics and volcanism justifies future research. Further multibeam mapping and rock sampling will construct a better picture of this active oceanic plate boundary. In particular, sampling of bathymetric lows along the ridge should be sampled to provide a full suite of rocks for the MRC and test the hypothesis that MRC seamounts were partly constructed by post-spreading magmatism. 
2. Submarine basaltic samples should be dated by radiogenic isotope dating methods (e.g. ${ }^{40} \mathrm{Ar}-{ }^{39} \mathrm{Ar}$ ). The combination of age and compositional data will place samples in their relevant volcano-tectonic setting and elucidate how the relic Macquarie spreading centre evolved with time and, therefore, diminishing seafloor spreading rates. This is particularly important for testing the hypothesis that Group 2 basalts were erupted during post-spreading magmatism at the MRC. On a broader scale, the age of oceanic crust that comprises the MRC and surrounding region is poorly constrained and requires better classification.

3. The major and trace element chemical analysis of MRC dredge samples undertaken for this thesis requires a complementary $\mathrm{Sr}-\mathrm{Nd}-\mathrm{Pb}-\mathrm{Hf}$ isotopic study in order to further characterise the mantle sources and processes of the relic Macquarie spreading centre. This will enable the enrichment of the mantle beneath the relic Macquarie spreading centre to be interpreted on a much larger scale, allowing comparison to the source of other enriched ocean basalts in the region (e.g. Chatham Islands, Auckland Islands and Balleny Islands). This work is important as only limited isotopic analyses of Macquarie Island volcanic rocks have been undertaken to date (Kamenetsky \& Maas, 2002).

4. Remote observation and dredge sampling undertaken for this study and field studies on Macquarie Island indicate that volcaniclastic breccias are relatively common along the MRC. This thesis showed that petrographic and geochemical studies of volcanic glass, present as shards in breccias or rinds on pillow lavas, provide valuable information on the modes of submarine eruption along the relic Macquarie spreading centre. An additional technique that should be combined with the methods used in this study is the analysis of volcanic glass volatile element $\left(\mathrm{H}_{2} \mathrm{O}\right.$ and $\mathrm{CO}_{2}$ ) contents by Fourier Transform Infrared (FTIR) spectrometry. Quantitative measurement of glass volatile concentrations will allow comparison of magma types from the MRC to those from other mid-ocean ridges and submarine volcanoes that have been the focus of studies on the compositional controls of explosive submarine volcanic eruption (e.g. Fouquet et al., 1998; Hekinian et al., 2000). Moreover, if the glasses were volatile-saturated, acquisition of water contents will allow direct quantification of eruption depths. This will place important constraints 
on physical parameters of the Australia-Pacific plate boundary during its divergent stages (i.e. seafloor depth). The amount of uplift of MRC crust from initial eruption depth to current summit depth is particularly interesting given the role that the MRC plays in controlling the pathway of the Antarctic Circumpolar Current (ACC).

5. The volcano-tectonic evolution of the MRC, as presented in this thesis, provides a context for further study of volcanism in the region. Solander Island is a young arc volcano (Mortimer et al., 2008) and represents an opportunity to test hypotheses for adakite magma genesis. Models for slab melting using the composition of MRC oceanic crust, as constrained by the geochemical study in this thesis, can now be evaluated. Hjort Plateau seamounts have not been sampled to date, despite their apparent importance to the volcano-tectonic setting of the Hjort region. In particular, it remains unknown whether subduction of the Australian plate at the Hjort Trench has resulted in arc volcanism on the Pacific plate, as has been suggested for Solander Island and the Puysegur Trench. A petrochemical study of Hjort Plateau seamounts will provide information on the evolution of the Hjort region of the Australia-Pacific plate boundary south of New Zealand and the nature of the Pacific upper mantle.

6. The interpretation that seamount summit plateaux represent wave-eroded sections of the ridge indicates that uplift of MRC oceanic crust was sufficient to elevate seamounts to near-sea-level. However, the current depth of the summit plateaus of seamount 4 (600 m below sea-level) and seamount 8 (450 m below sealevel) require subsidence of MRC oceanic crust following wave erosion. Despite the current transpressional regime of the plate boundary, extension may be possible where the transform plate boundary changes orientation step over fault zones (Daczko et al., 2003). Therefore, while topographic highs (seamounts) were the focus of this study, investigation of topographic lows (fault step-over basins and breaks between ridge segments) will provide more information on how tectonic processes control the morphology of the MRC.

7. The summit plateau of seamount 8 is marked by bifurcating ridges and crosscutting furrows. Morphology of the furrows is consistent with features produced by 
iceberg-keel scouring; the ridges are likely to be related to the underlying geological structure. Sampling of the well-sorted clastic substrate will provide information on the past erosional environment of the seamount during wave erosion and identification of foreign rock types ("drop stones") would provide evidence for past iceberg scouring. Sampling of faunal assemblages on the summits may also help to constrain paleo-depths of the seamounts. The recovery of plutonic and hypabyssal rocks from seamount 8 indicates that this section of the MRC has experienced significant crustal exhumation resulting in lower levels of the lithosphere to be exposed. High-resolution sampling of the seamount would provide a suite of rock samples suitable to test the genetic relationship (or lack of) between plutonic rocks, hypabyssal dykes and volcanic lavas. Such a study would contribute to work that has noted the absence of a genetic relationship between the enriched extrusive sequence and highly refractory peridotites on Macquarie Island (Dijkstra et al., 2009). 


\section{REFERENCES}

Adamson, D. A., Selkirk, P. M., Price, D. M., Ward, N., and Selkirk, J. M., 1996. Pleistocene uplift and paleoenvironments of Macquarie Island: evidence from paleobeaches and sedimentary deposits. Papers and Proceedings of the Royal Society of Tasmania 130, 25-32.

Allègre, C. J., and Turcotte, D. L., 1983. Implications of a two-component marblecake mantle. Nature 323, 123-127.

Baker, J. A., Thirlwall, M. F., and Menzies, M., A., 1996. Sr-Nd-Pb isotopic and trace element evidence for crustal contamination of plume-derive flood basalts: Oligocene flood volcanism in western Yemen. Geochimica et Cosmochimica Acta $60,2559-2581$.

Batiza, R., 1977. Petrology and chemistry of Guadalupe Island: an alkalic seamount on a fossil ridge crest. Geology 5, 760-764.

Batiza, R., and Vanko, D., 1984. Volcanic development of small oceanic central volcanoes on the flanks of the East Pacific Rise inferred from narrow beam echo-sounder surveys. Marine Geology 54, 53-90.

Batiza, R., and Vanko, D. A., 1985. Petrologic evolution of large failed rifts in the eastern Pacific: petrology of volcanic and plutonic rocks from the Mathematician Ridge and the Guadalupe Trough. Journal of Petrology 26, 564-602.

Bazylev, B. A., and Kamenetsky, V. S., 1998. Genesis of peridotites from the ophiolite complex of Macquarie Island, southwestern Pacific Ocean. Petrology 6, 335-350.

Bender, J. F., Hodges, F. N., and Bence, A. E., 1978. Petrogenesis of basalts from the project FAMOUS area: experimental study from 0 to 15 kbars. Earth and Planetary Science Letters 41, 277-302. 
Bohrson, W., and Reid, M., 1995. Petrogenesis of alkaline basalts from Socorro Island, Mexico: trace element evidence for contamination of ocean island basalt in the shallow ocean crust. Journal of Geophysical Research 100, $24,555-24,576$.

Bostock, H. C., 2011. RV Tangaroa voyage report: TAN1106 - Solander Trough $10^{\text {th }}$ April $-1^{\text {st }}$ May 2011. Unpublished NIWA voyage report, 59pp.

Bottinga, Y., Allègre, C. J., and Thompson, R. N., 1978. Partial melting under spreading ridges. Philosophical Transactions of the Royal Society London 288, 501-525.

Bottinga, Y., and Javoy, M., 1990. Mid-ocean ridge basalt degassing: bubble nucleation. Journal of Geophysical Research 95, 5125-5131.

Brodie, J. W., and Dawson, E. W., 1965. Morphology of North Macquarie Ridge. Nature 207, 844-845.

Cande, S. C., and Stock, J. M., 2004. Pacific-Antarctic-Australia motion and the formation of the Macquarie Plate. Geophysical Journal International 157, 399414.

Carter, L., Neil, H. L., and Northcote, L., 2002. Late Quaternary ice-rafting events in the SW Pacific Ocean, off eastern New Zealand. Marine Geology 191, 19-35.

Cashman, K., 1992. Groundmass crystallization of Mount St Helens Dacite, 19801986-a tool for interpreting shallow magmatic processes. Contributions to Mineralogy and Petrology 109, 431-449.

Castillo, P. R., Clague, D. A., Davis, A. S., and Lonsdale, P. F., 2010. Petrogenesis of Davidson Seamount lavas and its implications for fossil spreading centre and intraplate magmatism in the eastern Pacific. Geochemistry, Geophysics, Geosystems 11, Q02005, doi: 10.1029/2009GC002992.

Chaytor, J. D., Keller, R. A., Duncan, R. A., and Dziak, R. P., 2007. Seamount morphology in the Bowie and Cobb hot spot trails. Gulf of Alaska, 
Geochemistry, Geophysics, Geosystems 8, Q09016, doi:10.1029/2007GC001712.

Clague, D. A., Holcomb, R. T., Sinton, J. M., Detrick, R. S., and Torresan, M. E., 1990. Pliocene and Pleistocene alkalic flood basalts on the seafloor north of the Hawaiian Islands. Earth and Planetary Science Letters 98, 175-191.

Clague, D. A., Reynolds, J. R., and Davis, A. S., 2000a. Near-ridge seamount chains in the northeastern Pacific Ocean. Journal of Geophysical Research 105, 541561.

Clague, D. A., Davis, A. S., Bischoff, J. L., Dixon, J. E., and Geyer, R., 2000b. Lava bubble-wall fragments formed by submarine hydrovolcanic explosions on Lo'ihi Seamount and Kilauea Volcano. Bulletin of Volcanology 61, 437-449.

Clague, D. A., Batiza, R., Head. J., and Davis, S., 2003. Pyroclastic and hydroclastic deposits on Loihi Seamount, Hawaii. In: White, J. D. L., Smellie, J. L., Clague, D. A. (Eds.), Explosive Subaqueous Volcanism. American Geophysical Union Monograph, vol. 140, pp. 73-95.

Clague, D. A., Paduan, J. B., and Davis, A. S., 2009a. Widespread strombolian eruptions of mid-ocean ridge basalt. Journal of Volcanology and Geothermal Research 180, 171-188.

Clague, D A., Paduan, J. B., Duncan, R. A., Huard, J. J., Davis, A. S., Castillo, P. R., Lonsdale., P., and DeVogelaere, A., 2009b. Five million years of compositionally diverse, episodic volcanism: construction of Davidson Seamount atop an abandoned spreading centre. Geochemistry, Geophysics, Geosystems 10, Q12009, doi: 10.1029/2009GC002665.

Clark, P. U., and Mix, A. C., 2002. Ice sheets and sea level of the Last Glacial Maximum. Quaternary Science Reviews 21, 1-7.

Collot, J. Y., Lamarche, G., Wood, R. A., Deltiel, J., Sosson, M., Lebrun, J.-F., and Coffin, M. F., 1995. Morphostructure of an incipient subduction zone along a transform plate boundary; Puysegur Ridge and Trench. Geology 23, 519-522. 
Cullen, D. J., 1967. Island arc development in the Southwest Pacific. Tectonophysics 4, 163-172.

Daczko, N. R., Wertz, K. L., Mosher, S., Coffin, M. F., and Meckel T. A., 2003. Extension along the Australia-Pacific transpressional transform plate boundary near Macquarie Island. Geochemistry, Geophysics, Geosystems 4, 1080, doi:10.1029/2003GC000523.

Daczko, N. R., Harb, N., Portner, R. A., and Dickinson J. A., 2009. Geochemical fingerprint of hyaloclasts in glassy fragmental rocks of Macquarie Island (Southern Ocean): implications for volcanogenic sedimentary processes at a waning mid-ocean ridge. Australian Journal of Earth Sciences 56, 951-963.

Das, S., 1993. The Macquarie Ridge Complex earthquake of 1989. Geophysical Journal International 115, 778-798.

Davis, A. S., Gunn, S. H., Bohrson, W. A., Gray, L.-B., and Hein, J. R., 1995. Chemically diverse, sporadic volcanism at seamounts offshore southern and Baja California. Geological Society of America Bulletin 107, 554-570.

Davis, A. S., and Clague, D. A., 2006. Volcaniclastic deposits from the North Arch volcanic field, Hawaii: explosive fragmentation of alkalic lava at abyssal depths. Bulletin of Volcanology 68, 294-307.

DeMets, C., Gordon, R., G. Argus, D. F., and Stein S., 1994. Effect of recent revisions to the geomagnetic reversal time scale on estimates of current plate motions. Geophysical Research Letters 21, 2191-2194.

Dickinson, J. A., Harb, N., Portner, R. A., and Daczko N. R., 2009. Glassy fragmental rocks of Macquarie Island (Southern Ocean): mechanisms of formation and deposition. Sedimentary Geology 216, 91-113.

Dijkstra, A. H., and Cawood, P. A., 2004. Base-up growth of ocean crust by multiple phases of magmatism: field evidence from Macquarie Island. Journal of the Geological Society London 161, 739-742. 
Dijkstra, A. H., Sergeev, D. S., Spandler, C. A., Pettke, T., Meisel, T., and Cawood, P. A., 2009. Highly refractory peridotites on Macquarie Island and the case for anciently depleted domains in the Earth's mantle. Journal of Petrology 51, 469-493.

Dixon, J. E., 1997. Degassing of alkalic basalts. American Mineralogy 82, 368-378.

Donnelly, K. E., Goldstein, S. L., Langmuir, C. H., and Spiegelman, M., 2004. Origin of enriched ocean basalt and implications for mantle dynamics. Earth and Planetary Science Letters 226, 347-366.

Duncan, R. A., and Varne R. J., 1988. The age and distribution of igneous rocks of Macquarie Island. Papers and Proceedings of the Royal Society of Tasmania $122,45-50$.

Ewing, M., and Heezen, B. C., 1956. Some problems with Antarctic Submarine Geology. Geophysical Monograph 1, 75-81.

Fouquet, Y., Eissen, J.-P., Ondréas, H., Barriga, F., Batiza, R., and Danyushevsky L., 1998. Extensive volcaniclastic deposits at the Mid-Atlantic Ridge axis: results of deep-water basaltic explosive activity? Terra Nova 10, 280-286.

Frohlich, C., Coffin, M. F., Massell, C., Mann, P., Schuur, C. L., Davis, D., Jones, T., and Karner G., 1997. Constraints on Macquarie Ridge tectonics provided by Harvard focal mechanisms and teleseismic earthquake locations. Journal of Geophysical Research 102, 5029-5041.

Galer, S. J. G., and O'Nions, R. K., 1986. Magmagenesis and the mapping of chemical and isotopic variations in the mantle. Chemical Geology 56, 45-61.

Galindo-Saldívar, J., Jabaloy, A., Maldonado, A., Martínez-Martínez, J. M., de Galdeano, C. S., Somoza, L., and Surinach, E., 2000. Deep crustal structure of the area of intersection between the Shackleton Fracture Zone and the West Scotia Ridge (Drake Passage, Antarctica). Tectonophysics 320, 123-139. 
Goff, J. A., and Austin, J. A. Jr., 2009. Seismic and bathymetric evidence for four different episodes of iceberg scouring on the New Jersey outer shelf: possible correlation to Heinrich events. Marine Geology 266, 244-254.

Goscombe, B. D., and Everard, J. L., 1998. Geology of Macquarie Island. Geological Atlas 1:10,000 Series, Mineral Resources, Hobart.

Goscombe, B. D., and Everard, J. L., 2001. Tectonic evolution of Macquarie Island: extensional structures and block rotations in oceanic crust. Journal of Structural Geology 23, 639-673.

Gregg, T. K. P., and Fink, J. H., 1995. Quantification of lava-flow morphology through analog experiments. Geology 23, 73-76.

Griffin, B. J., and Varne, R., 1980. The Macquarie Island ophiolite complex: MidTertiary oceanic lithosphere from a major ocean basin. Chemical Geology 30, 285-308.

Grove, T. L., and Bryan, W. B., 1983. Fractionation of pyroxene-phyric MORB at low pressure: an experimental study. Contributions to Mineralogy and Petrology 84, 293-309.

Haase, K. M., Beier, C., Fretzdorff, S., Leat, P. T., Livermore, R. A., Barry, T. L., Pearce, J. A., and Hauff, F., 2011. Magmatic evolution of a dying spreading axis: evidence for the interaction of tectonics and mantle heterogeneity from the fossil Phoenix Ridge, Drake Passage. Chemical Geology, 280, 115-125.

Hayes, D. E., and Talwani, M., 1972. Geophysical investigation of the Macquarie Ridge Complex, in, Hayes, D. E. (ed.), Antarctic Research Series: American Geophysical Union monograph 19, 211-234.

Hayes, G. P., Furlong, K. P., and Ammon, C. J., 2009. Intraplate deformation adjacent to the Macquarie Ridge south of New Zealand-the tectonic evolution of a complex plate boundary. Tectonophysics 463, 1-14.

Head, J. W., Wilson, L., and Smith, D. K., 1996. Mid-ocean ridge eruptive vent morphology and structure: evidence for dike widths, eruption rates, and 
evolution of eruptions and axial volcanic ridges. Journal of Geophysical Research 101, 28265-28280.

Head, J. W., and Wilson, L., 2003. Deep submarine pyroclastic eruptions: theory and predicted landforms and deposits. Journal of Volcanology and Geothermal Research 121, 155-191.

Hekinian, R., Pineau, F., Shilobreeva, S., Bideau, D., Gracia, E., and Javoy, M., 2000. Deep-sea explosive eruption on the Mid-Atlantic Ridge near $34^{\circ} 50^{\prime} \mathrm{N}$ : magma composition, vesicularity and volatile content. Journal of Volcanology and Geothermal Research 98, 49-77.

Hirschmann, M. M., 2000. Mantle solidus: experimental constraints and the effects of peridotite composition. Geochemistry, Geophysics, Geosystems 1, doi: 10.1029/2000GC000070.

Hirschmann, M. M., and Stolper, E. M., 1996. A possible role of garnet in the "garnet signature" in MORB. Contributions to Mineralogy and Petrology 124, 185-208.

Hoffman, A. W., Jochum, K. P., Seufert, M., and White, W. M., 1986. Nb and Pb in oceanic basalts: new constraints on mantle evolution. Earth and Planetary Science Letters 79, 33-45.

Kamenetsky, V. S., Everard, J. L., Crawford, A. J., Varne, R., Eggins, S. M., and Lanyon, R., 2000. Enriched end-member of primitive MORB melts: Petrology and geochemistry of glasses from Macquarie Island (SW Pacific). Journal of Petrology 41, 411-430.

Kamenetsky, V. S., and Maas, R., 2002. Mantle-melt evolution (dynamic source) in the origin of a single MORB suite: a perspective from magnesian glasses of Macquarie Island. Journal of Petrology 43, 1909-1922.

Kastens, K. A., 1987. A compendium of causes and effects of processes at transform faults and fracture zones. Reviews of Geophysics 25, 1554-1562.

Kay, R., Hubbard, N. J., and Gast, P. W., 1970. Chemical characteristics and origin of oceanic ridge volcanic rocks. Journal of Geophysical Research 75, 1585-1613. 
Klein, E. M., and Langmuir, C. H., 1987. Global correlations of ocean ridge basalt chemistry with axial depth and crustal thickness. Journal of Geophysical Research 92, 8089-8115.

Kokelaar, P., 1986. Magma-water interactions in subaqueous and emergent basaltic volcanics. Bulletin of Volcanology 48, 275-290.

Lamarche, G., Collot, J.-Y., Wood, R. A., Sosson, M., Sutherland, R., and Delteil, J., 1997. The Oligocene-Miocene Pacific-Australia plate boundary, south of New Zealand: evolution from oceanic spreading to strike-slip faulting. Earth and Planetary Science Letters 148, 129-139.

Lamarche, G., and Lebrun, J.-F., 2000. Transition from strike-slip faulting to oblique subduction: active tectonics at the Puysegur Margin, South New Zealand. Tectonophysics 316, 67-89.

Lamarche, G., Lurton, X., Augustin, J.-M., and Verdier, A.-L., 2011. Quantitative characterisation of seafloor substrate and bedforms using advanced processing of multibeam backscatter. Application to the Cook Strait, New Zealand. Continental Shelf Research 31, 93-109.

Lanyon, R., Varne, R., and Crawford, A. J., 1993. Tasmanian Tertiary basalts, the Balleny plume, and opening of the Tasman (southwest Pacific Ocean). Geology 21, 555-558.

Le Roux, P. J., le Roux, A. P., Schilling, J.-G., Shimizu, N., Perkins, W. W., and Pearce, N. J. G., 2002. Mantle heterogeneity beneath the southern Mid-Atlantic Ridge: trace element evidence for contamination of ambient asthenospheric mantle. Earth and Planetary Science Letters 203, 479-498.

Lundstrom, C. C., Sampson, D. E., Perfit, M. R., Gill, J., and Williams, Q., 1999. Insights into mid-ocean ridge basalt petrogenesis: U-series disequilibria from the Siqueiros Transform, Lamont Seamounts, and East Pacific Rise. Journal of Geophysical Research 104, 13035-13048. 
Macdonald, K. C., 1982. Mid-ocean ridges: fine-scale tectonic, volcanic and hydrothermal processes within the plate boundary zone. Annual Review of Earth and Planetary Sciences 10, 155-190.

Macdonald, G. A., and Katsura, T., 1964. Chemical composition of Hawaiian lavas. Journal of Petrology 5, 82-133.

Massell, C., Coffin, M. F., Mann, P., Mosher, S., Frohlich, C., Duncan, C. S., Karner, G., Ramsay, D., and Lebrun J.-F., 2000. Neotectonics of the Macquarie Ridge Complex, Australia-Pacific plate boundary, Journal of Geophysical Research $105,13,457-13,480$.

Matveyenkov, V. V., and Baranov, B. V., 1981. Magmatic rocks of the Macquarie Ridge (southwest part of the Pacific Ocean). International Geology Review 23, 417-425.

McBirney, A. R., 1963. Factors governing the nature of submarine volcanism. Bulletin of Volcanology 26, 455-469.

McKenzie, D. P., and O’Nions, R. K., 1991. Partial melt distributions from inversion of rare earth element concentrations. Journal of Petrology 32, 1021-1091.

Meckel, T. A., Coffin, M. F., Mosher, S., Symonds, P., Bernardel, G., and Mann P., 2003. Underthrusting at the Hjort Trench, Australia-Pacific plate boundary: Incipient subduction? Geochemistry, Geophysics, Geosystems 4, 1099. doi:10.1029/2002GC000498.

Meckel, T. A., Mann, P., Mosher, S., and Coffin M. F., 2005. Influence of cumulative convergence on lithospheric thrust fault development and topography along the Australia-Pacific plate boundary south of New Zealand. Geochemistry Geophysics Geosystems 6, Q09010. doi:10.1029/2005GC000914.

Menard, H. W., 1964. Marine geology of the Pacific. McGraw-Hill, New York, 271p.

Mortimer, N., 1995. Igneous and sedimentary rocks dredged from the northern Macquarie Ridge, Southern Ocean. Journal of Australian Geology and Geophysics 15, 529-537. 
Mortimer, N., Gans, P. B., and Mildenhall D. C., 2008. A middle-late Quaternary age for the adakitic arc volcanics of Hautere (Solander Island), Southern Ocean. Journal of Volcanology and Geothermal Research 178, 701-707.

Mosher, S., and Massell-Symons C. M., 2008. Ridge reorientation mechanisms: Macquarie Ridge Complex, Australia-Pacific plate boundary. Geology 27, 119122.

Mühe, R., Devey, C. W., and Bohrmann, H., 1993. isotope and trace element geochemistry of MORB from the Nansen-Gakkel ridge at $86^{\circ}$ north. Earth and Planetary Science Letters 120, 103-109.

Mühe, R., Bohrmann, H., Garbe-Schönberg, D., and Kassens, H., 1997. E-MORB glasses from the Gakkel Ridge (Arctic Ocean) at $87^{\circ} \mathrm{N}$ : evidence for the earth's most northerly volcanic activity. Earth and Planetary Science Letters 152, 1-9.

Niu, Y., and Batiza, R., 1997. Trace element evidence from seamounts for recycled oceanic crust in the Eastern Pacific mantle. Earth and Planetary Science Letters $148,471-483$.

Niu, Y., Collerson, K. D., Batiza, R., Wendt, I. J., and Regelous, M., 1999. Origin of enriched type mid-ocean ridge basalts at ridges far from mantle plumes: the East Pacific Rise at $11^{\circ} 20^{\prime}$ N. Journal of Geophysical Research 104, 7067-7087.

Niu, Y., Regelous, M., Wendt, I. J., Batiza, R., and O'Hara, M. J., 2002. Geochemistry of near-EPR seamounts: importance of source vs. process and the origin of enriched mantle component. Earth and Planetary Science Letters 199, 327345.

Paduan, J. B., Clague, D. A., and Davis A. S., 2009. Evidence that three seamounts off southern California were ancient islands. Marine Geology 265, 146-156.

Pockalny, R. A., 1997. Evidence of transpression along the Clipperton Transform: implications for processes of plate boundary reorganisation. Earth and Planetary Science Letters 146, 449-464. 
Pockalny, R. A., Fox, P. J., Fornari, D. J., Macdonald, K. C., and Perfit, M. R., 1997. Tectonic reconstruction of the Clipperton and Siqueirous Fracture Zones: evidence and consequences of plate motion change over the last $3 \mathrm{Myr}$. Journal of Geophysical Research 102, 3167-3181.

Portner, R. A., Daczko, N. R., and Dickinson, J. A., 2009. Vitriclastic lithofacies from Macquarie Island (Southern Ocean): compositional influence on abyssal eruption explosivity in a dying Miocene spreading ridge. Bulletin of Volcanology 72, 165-183.

Quilty, P. G., Crundwell, M. P., and Wise, S. W. Jr., 2008. Microplankton provide $9 \mathrm{Ma}$ age for sediment in the Macquarie Island ophiolite complex. Australian Journal of Earth Science 55, 1119-1125.

Reay, A., 1986. Andesites from Solander Island. Bulletin of the Royal Society of New Zealand 23, 373-343.

Reay, A., and Parkinson, D., 1997. Adakites from Solander Island, New Zealand. New Zealand Journal of Geology and Geophysics 40, 121-126.

Ruff, L. J., Given, J. W., Sanders, C. O., and Sperber, C. M., 1989. Large earthquakes in the Macquarie Ridge Complex: transitional tectonics and subduction initiation. Pure Applied Geophysics 129, 71-129.

Schilling, J.-G., and Ridley, W. I., 1975. Volcanic rocks from DSDP leg 29: petrography and rare-earth abundances. Initial Reports of the Deep Sea Drilling Project 29, 1117-1121.

Schuur, C. L., Coffin, M. F., Frohlich, C., Massell, C. G., Karner, G. D., Ramsay, D., and Caress, D. W., 1998. Sedimentary regimes at the Macquarie Ridge Complex; interaction of Southern Ocean circulation and plate boundary bathymetry. Paleoceanography 13, 646-670.

Selkirk, P. M., Seppelt, R. D., and Selkirk, D. R., 1990. Subantarctic Macquarie Island: environment and biology. Cambridge, Cambridge University Press, 285 pp. 
Shaw, D. M., 1970. Trace element fractionation during anatexis. Geochimica et Cosmochimica Acta 34, 237-243.

Shaw, A. S., Behn, M. D., Humphris, S. E., Sohn, R. A., and Gregg, P. M., 2010. Deep pooling of low degree melts and volatile fluxes at the $85^{\circ} \mathrm{E}$ segment of the Gakkel Ridge: evidence from olivine-hosted melt inclusions and glasses. Earth and Planetary Science Letters 289, 311-322.

Sohn, R. A., Willis, C., Humphris, S., Shank, T. M., Singh, H., Edmonds, H. N., Kunz, C., Hedman, U., Helmke, E., Jakuba, M., Liljebladh, B., Linder, J., Murphy, C., Nakamura, K.-I., Sato, T., Schlindwein, V., Stranne, C., Tausenfreund, M., Upchurch, L., Winsor, P., Jakobsson, M., and Soule, A., 2008. Explosive volcanism on the ultraslow-spreading Gakkel ridge, Arctic Ocean. Nature 453, 1236-1238.

Sonder, L. J., and Pockalny, R. A., 1999. Anomalously rotated abyssal hills along active transforms: distributed deformation of oceanic lithosphere. Geology 27, 1003-1006.

Sparks, R. S. J., 1978. The dynamics of bubble formation and growth in magmas: a review and analysis. Journal of Volcanology and Geothermal Research 3, 1-37.

Standish, J. J., Dick, H. J. B., Michael, P. J., Melson, W. G., and O'Hearn, T., 2008. MORB generation beneath the ultraslow spreading Southwest Indian Ridge (9$25^{\circ} \mathrm{E}$ ): major element chemistry and the importance of process versus source. Geochemistry Geophysics Geosystems 9, Q05004. doi: 10.1029/2008GC001959.

Staudigel, H., and Clague, D. A., 2010. The geological history of deep-sea volcanoes: biosphere, hydrosphere and lithospheric interactions. Oceanography 23, 5871.

Staudigel, H., Koppers, A. A. P., Lavelle, J. W., Pitcher, T. J., and Shank, T. M., 2010. Defining the word "seamount". Oceanography 23, 20-21. 
Summerhayes, C. P., 1967. New Zealand region volcanism and structure. Nature $215,610-611$.

Summerhayes, C. P., 1969. Marine geology of the New Zealand subantarctic sea floor. New Zealand Department of Scientific and Industrial Research Bulletin 190.

Sun, S.-S., and McDonough, W. F., 1989. Chemical and isotopic systematics of oceanic basalts: implications for mantle compositions and processes. Geological Society of London Special Publications 42, 313-345.

Sutherland, R., 1995. The Australia-Pacific boundary and Cenozoic plate motions in the SW Pacific: some constraints from Geosat data. Tectonics 14, 819-831.

Sutherland, R., Barnes, P., and Uruski, C., 2006. Miocene-Recent deformation, surface elevation, and volcanic intrusion of the overriding plate during subduction initiation, offshore southern Fiordland, Puysegur margin, southwest New Zealand. New Zealand Journal of Geology and Geophysics 49, 131-149.

Taylor, S. R., and McLennan, S. M., 1985. The continental crust: its composition and evolution. London: Blackwell, 312pp.

Thirlwall, M. F., Upton, B. G. J., and Jenkins, C., 1994. Interaction between continental lithosphere and the Iceland plume - $\mathrm{Sr}-\mathrm{Nd}-\mathrm{Pb}$ isotope chemistry of Tertiary basalts, NE Greenland. Journal of Petrology 35, 839-879.

Varne, R., Gee, R., and Quilty, P., 1969. Macquarie Island and the cause of oceanic linear magnetic anomalies. Science 166, 230-233.

Varne, R., Brown, A. V., and Falloon, T., 2000. Macquarie Island; its geology, structural history, and the timing and tectonic setting of its N-MORB to EMORB magmatism. In Dilek, Y., et al. (eds.), Ophiolites and oceanic crust; new insights from field studies and the Ocean Drilling Program: Geological Society of America Special Paper 349, 301-302. 
Vergniolle, S., Mangan, M., 2000. Hawaiian and strombolian eruptions. In: Sigurdsson, H., Houghton, B. F., McNutt, S. R., Rymer, H., Stix, J. (Eds.) Encyclopedia of volcanoes. Academic, San Diego, 447-461.

Walcott, R. I., 1984. Reconstructions of the New Zealand region for the Neogene. Palaeogeography Palaeoclimatology Palaeoecology 46, 217-231.

Waters, C. L., Sims, K. W. W., Perfit, M. R., Blichert-Toft, J., and Blusztajn, J., 2011. Perspective on the genesis of E-MORB from chemical and istotopic heterogeneity at 9-10N East Pacific Rise. Journal of Petrology 52, 565-602.

Watkins, N. D., and Gunn, B. M., 1971. Petrology, geochemistry and magnetic properties of some rocks dredged from the Macquarie Ridge. New Zealand Journal of Geology and Geophysics 14, 153-168.

Watson, C., Burgette, R., Tregoning, P., White, N., Hunter, J., Coleman, R., Handsworth, R., and Brolsma, H., 2010. Twentieth century constraints on sea level change and earthquake deformation at Macquarie Island. Geophysical Journal International, doi: 10.1111/j.1365-246X.2010.04640.x.

Wertz, K. L., 2003. From seafloor spreading to uplift: the structural and geochemical evolution of Macquarie Island on the Australia-Pacific plate boundary. Ph.D. thesis, The University of Texas at Austin, Austin. 169pp.

Wertz, K. L., Mosher, S., Daczko, N. R., and Coffin, M. F., 2003. Macquarie Island's Finch-Langdon fault: a ridge-transform inside corner structure.

Wilson, J. T., 1965. A new class of faults and their bearing on continental drift. Nature 207, 343-347.

Wood, R., Lamarche, G., Herzer, R. Deltiel, J., and Davy, B., 1996. Paleogene seafloor spreading in the southeast Tasman Sea. Tectonics 15, 966-975.

Wright, A. C., and Kyle, P. R., 1990. Volcanoes of the Antarctic plate and Southern Oceans. In LeMausier, W. E., Thomson, J. W. (eds.), Antarctic Research Series: American Geophysical Monograph 48, 449-453. 
Zindler, A., and Hart, S. R., 1986. Chemical geodynamics. Annual Review of Earth and Planetary Sciences 14, 493-571. 


\section{APPENDIX 1:}

\section{MULTIBEAM MAPPING TECHNIQUES}

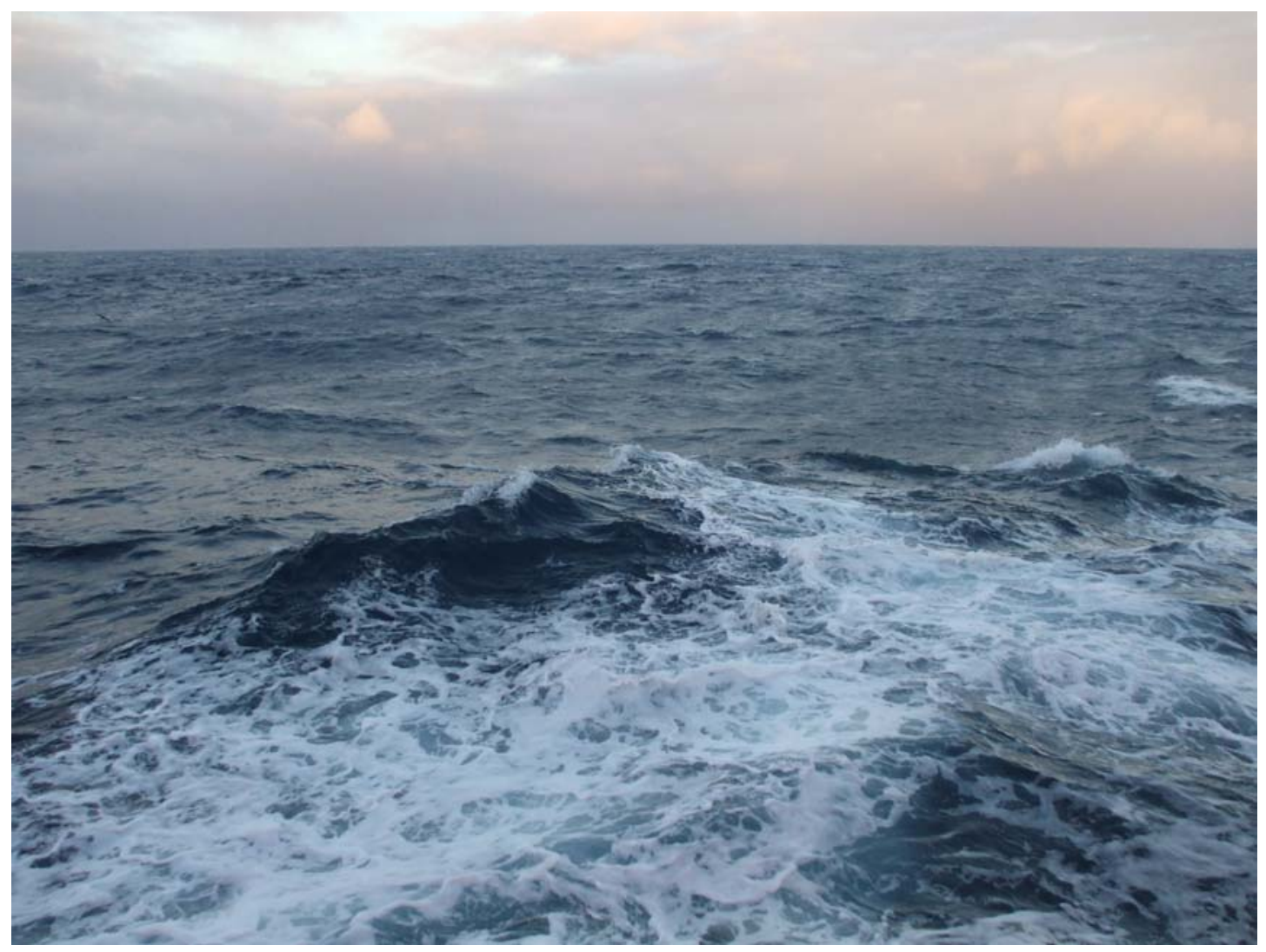

Plate 8. Waves roll out across the Southern Ocean. 


\section{A1.1 Bathymetry Resolution}

Bathymetry calculation involves a coupled time-angle measurement which allows a reconstruction of the wave trajectory so that the depth to the seafloor at each incident beam location can be calculated:

$$
Z=c T / 2
$$

Where $\mathrm{Z}$ is depth, $\mathrm{c}$ is the speed of sound in water, and $\mathrm{T}$ is the two-way travel time of the signal. When these measurements are represented in a bathymetric map, it is important to set the resolution of the image to best suit the data. The resolution is dependent on the water depth, such that a larger resolution step suits regions of deeper bathymetry and data collected in shallower seafloor can be represented by a smaller resolution step (Figure A1.1).

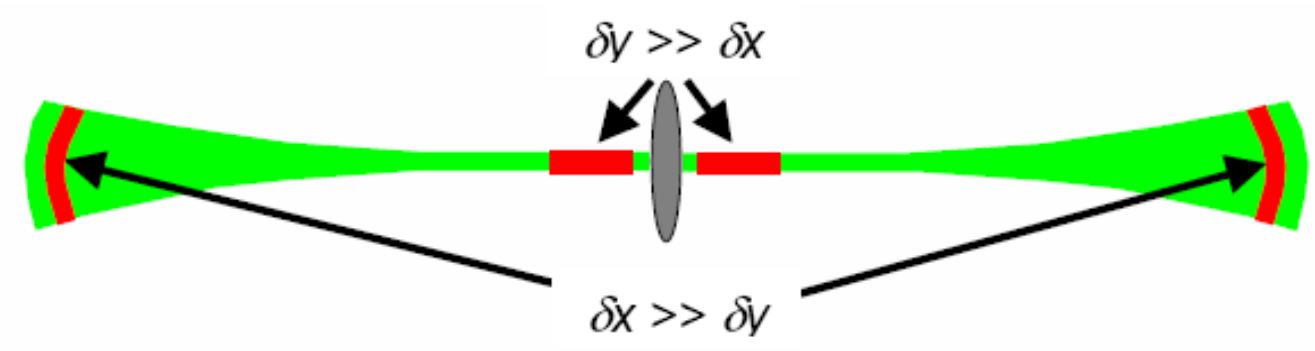

Figure A1.1. Resolution in the longitudinal $(\delta x)$ and transverse $(\delta y)$ directions.

In the longitudinal direction, the resolution is given by:

$$
\delta x=R \theta_{L}
$$

Where $\delta x$ is the resolution step, $R$ is the oblique distance $(R=H / \cos \theta$, where $H$ is water depth and $\theta$ is the angle of beam emission) and $\theta_{\mathrm{L}}$ is the horizontal opening of the beam trajectory.

In the transverse direction, the resolution is given by:

$$
\delta y=c T / 2 \sin \theta
$$

Where $\delta y$ is the resolution step, $c$ is the speed of sound in water, $T$ is the acoustic signal duration and $\theta$ is the angle of beam emission. 


\section{A1.2 Backscatter processing steps}

The strength of the reflected acoustic signal is measured simultaneously with the bathymetry and quantified as the backscatter strength (BS) in dB units. Backscatter strength serves as a proxy for seafloor composition due to the physical properties of the material that reflects the acoustic signal (Lamarche et al., 2000). However, there are several considerations and adjustments that need to be made to the original data in order to obtain meaningful final results. The following list outlines the steps involved in the process of converting raw backscatter data into final reflectivity images of the seafloor:

1. Bathymetry mosaic. The lines of interest are assembled to generate a bathymetric map of the seafloor in latitude and longitude for each seamount. A line is the swath coverage of the seafloor.

2. Image resolution. The image resolution is set to best represent the data of the lines which comprise the bathymetry mosaic. As explained above, the resolution depends on the seafloor depth.

3. Backscatter mosaic. The lines of interest are pieced together to generate an image of seafloor reflectivity in latitude and longitude.

4. Calibration of reflectivity data. The backscatter data is calibrated through the computation of the transmission directivity pattern. This involves the application of a specific gain to each angular sector of the multibeam and a correction for the signal insonification area. An absorption coefficient for the attenuation of sound waves in water is also calculated from the Levitus database (an atlas of oceanic parameters). Thus, the data is calibrated for the loss of the transmitted and received signals in accordance with the time varying gain law (TVG), which recognizes that vertical reflectance will be stronger than reflectance at oblique angles.

5. Statistical compensation of reflectivity image. A statistical compensation can be applied to the image for visual purposes. Compensation curves define the average reflectivity intensity as a function of the incidence angle. By calculating and subtracting a compensation curve from the data, the specular signal (bright band in 
the middle of swath lines due to strong vertical reflectance) is attenuated and a more homogeneous image is achieved, enabling easier distinction of geological features and domains.

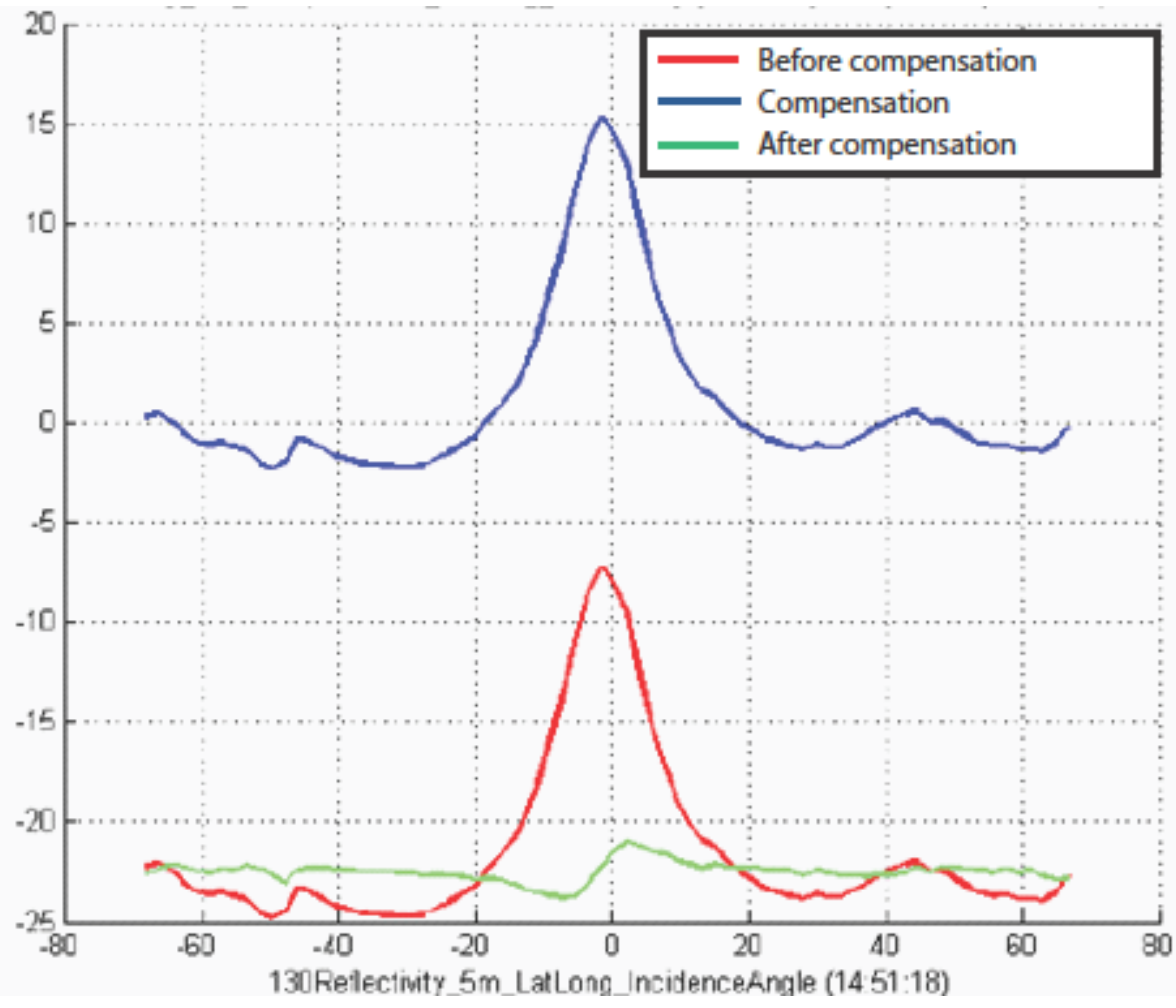

Figure A1.2. Example of a compensation curve applied to original backscatter data to correct for the specular signal (strong vertical reflectance). Horizontal axis displays beam incidence angle in degrees from vertical. Vertical axis displays backscatter strength (in $\mathrm{dB}$ ).

6. Global compensation. A compensation curve is calculated for the entire image and applied as an initial correction for the specular signal.

7. Regional compensation. Compensation curves are calculated and applied to distinct regions of the globally compensated image in an attempt to generate an homogeneous map with minimal fluctuations in backscatter intensity between different swath lines or water depths. The regions are delineated by outlining the area of interest to produce a 'mask', for which a compensation curve is then calculated and applied.

8. Speckle filtering. To make areas of the map clearer so that fine-scale features can be observed, a speckle filter is applied. Speckle is caused by roughness and microrelief on the seafloor that can diffuse or scatter the reflected sound waves. Applying the filter allows the noise in the reflected data to be reduced, producing a more 
smoothed image which is easier to analyse for qualitative purposes due to the elimination of small variations in reflectivity strength.

9. Maps are then ready for qualitative description and analysis of submarine geology. 


\section{APPENDIX 2:}

\section{SUBSTRATE CLASSIFICATION GUIDE}

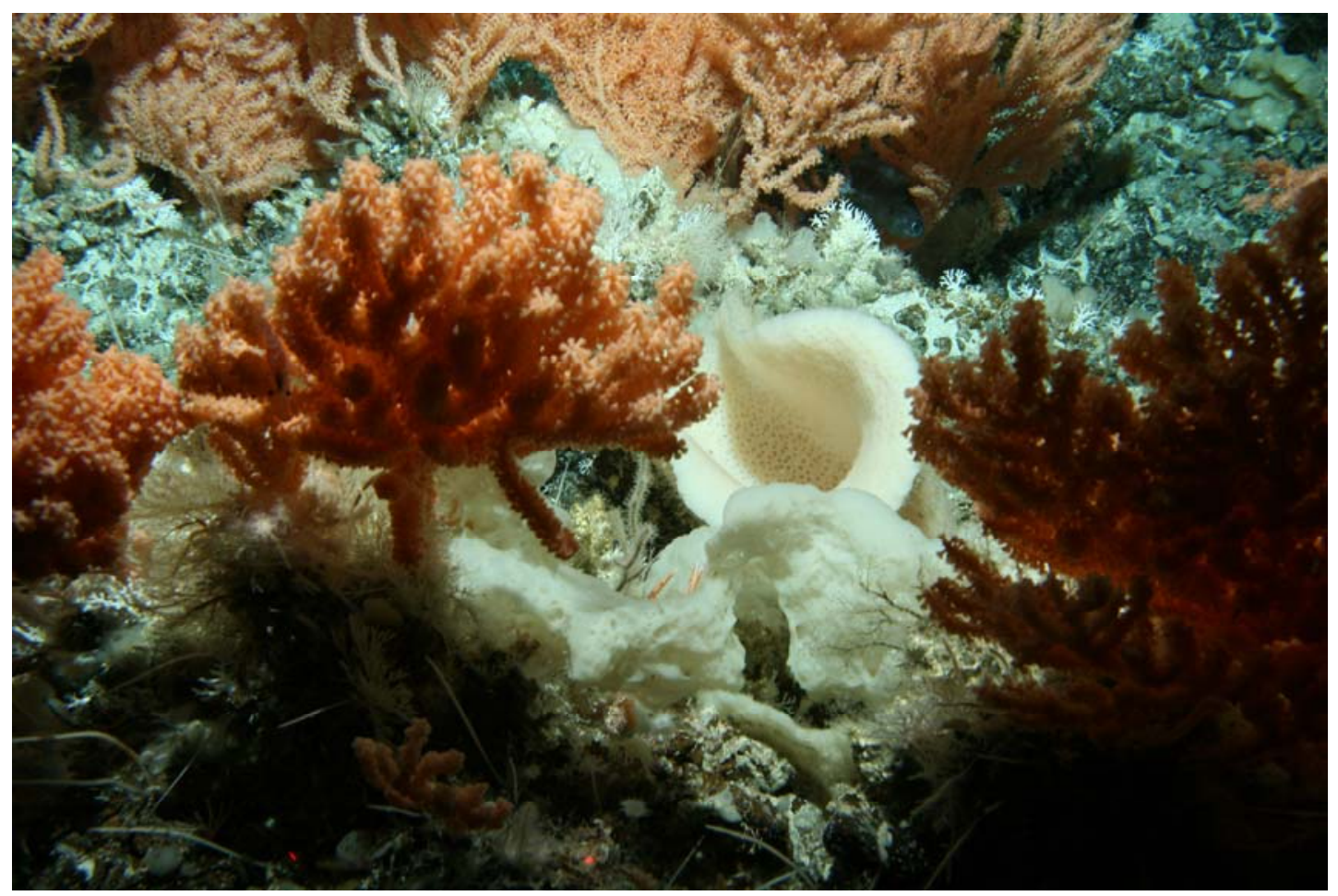

Plate 9. A close-up photograph of the seafloor captures a miniature garden of corals on seamount 9. 


\section{A2.1 DTIS specifications}

Remote observation of MRC seafloor was achieved by deployment of the DeepTowed Imaging System (DTIS). DTIS is equipped with a high resolution video camera and digital SLR still camera. The cameras are mounted on a steel frame which is lowered to the seafloor by a single core steel-armoured cable from the RV Tangaroa. The system is operational to water depths of $6,000 \mathrm{~m}$ and is generally towed at a speed of $<1$ knot. Video tape duration is ca. $1 \mathrm{hr}$ and the still camera takes one photograph every $20 \mathrm{~s}$.

Table A2.1. DTIS technical specifications.

\begin{tabular}{|l|l|}
\hline Tow cable type & Rochester 1-H-422A single core steel-armoured cable \\
\hline Max. cable length & $9,000 \mathrm{~m}$ \\
\hline Vehicle dimensions & $2.25 \mathrm{~m}$ long $\times 1.05 \mathrm{~m}$ wide $\times 1.65 \mathrm{~m}$ wide \\
\hline Vehicle weight & $280 \mathrm{~kg}$ \\
\hline Typical towing speed & $<1 \mathrm{knot}$ \\
\hline Max. operational depth & $6,000 \mathrm{~m}$ \\
\hline Video camera & Sony HCR-HC1E high definition camera \\
\hline Video tape duration & 63 min \\
\hline Video lighting & $2 \times 225$ W Deep Sea Power and Light halogens \\
\hline Still camera & 10 megapixel Canon 350D with 24 mm lens \\
\hline Images/transect (avg) & 230 \\
\hline Electronic flash & $\begin{array}{l}3 \times \text { Canon 580EX housed in Benthos 25 cm-diameter glass } \\
\text { sphere }\end{array}$ \\
\hline Shooting interval & $20 \mathrm{~s}$ \\
\hline Acoustic altimeter & Tritech PA200 \\
\hline Depth sensor & SeaBird SBE50 \\
\hline Data communications & Modified DSL modems and video codecs providing 384Mbps \\
\hline
\end{tabular}

\section{A2.2 Substrate classification guide}

Images acquired from DTIS deployment along the MRC reveal a range of volcanic features (Chapter 3). In order to document the nature of past mid-ocean ridge volcanism at the Australia-Pacific plate boundary, the variety of preserved lava flow morphologies were recognised and recorded. Other substrate types identified from remote observation of the seafloor include biogenic and clastic material. I 
developed a classification guide to aid description and definition of seamount substrates when processing images from DTIS deployment along the MRC. The aim of producing the classification guide was to select and display characteristic examples of volcanic features that could then be used to aid their recognition throughout the dataset. This ensured consistent classification of MRC substrates throughout DTIS data processing. The percentage cover of different substrate types in individual images from the 21 DTIS transects was recorded in Excel spreadsheets. The data and the classification guide were made available to biologists from NIWA for their work on benthic ecosystems and habitats.

Figures A2.1 to A2.5 display examples of the main lava flow types identified by remote observation. The scale bar is $100 \mathrm{~cm}$, except where stated. Classification followed the description of lava flow morphology by Gregg and Fink (1995). Identification and recognition of volcaniclastic breccia lithotypes was aided by recovery of breccia samples by epibenthic dredging. The figures are described below:

Figure A2.1 shows examples of pillow lavas from the MRC seafloor: (a) singular rounded pillow lava head (bottom left) with characteristic bread-crust (cracked) surface; (b) lava flow comprised of several bulbous pillows, covered by manganese coating and biogenic rubble; (c) large pillow lava head (centre) surrounded and covered by biogenic rubble; (d) pillow lava flow, inhabited by several species of coral.

Figure A2.2 displays a collection of massive lava flows: (a) ca. 2 m-high exposure of a massive lava flow; (b) blocky and angular surface of a massive flow emerging from sand and biogenic rubble; (c) close-up image of a massive lava flow surface; (d) massive lava flow (bottom right), with surrounding lava talus.

Figure A2.3 shows a collection of sheet lava flows: (a) sheet lava that flowed downslope (towards top of page) covered by a veneer of biogenic rubble; (b) sheet lava flow (oriented toward top right of page) covered by veneer of sand and biogenic rubble; (c) surface of sheet lava flow covered by biogenic rubble; (d) surface of sheet lava flow. 
Figure A2.4 displays examples of volcaniclastic breccia lithotypes: (a) pillowfragment volcaniclastic breccia (bottom left) comprised of angular lava clasts cemented by orange palagonite matrix; (b) pillow-fragment breccia comprised of sub-rounded lava clasts; (c) pillow-fragment breccia comprised of sub-angular lava clasts $(<50 \mathrm{~cm})$ cemented by orange palagonite matrix; (d) volcaniclastic breccia comprised of sub-rounded, glass and lava clasts $(<5 \mathrm{~cm})$ and palagonite matrix.

Figure A2.5 display the difference between lava talus and clastic material: (a) basaltic talus on a slope of seamount 5 is comprised of angular blocks of dark lava; (b) angular brown lava and breccia talus on seamount 9; (c) clastic material comprising the substrate of seamount 8 is well-rounded and well-sorted; (d) clastic material on seamount 8 is well-sorted and sediment size is generally $<2 \mathrm{~cm}$.

\section{A2.3 Substrate descriptors}

These qualitative definitions were used in combination with the visual examples in order to characterise substrate types:

Pillow lava: rounded lava head forms with characteristic bread-crust (cracked) outer surface.

Massive lava: characterised by blocky or angular surface features and occur as thick flows.

Sheet lava: planar flows with little or no surface features and relief.

Volcaniclastic breccia: agglomerate of fragmented volcanic lava and glass, generally cemented by a matrix of hydrothermally altered palagonite which displays a characteristic orange colour.

Lava talus: coarse, angular material that has been abraded from lava flows.

Clastic: refers to detrital material that cannot be unequivocally linked to provenance from a proximal volcanic source. 


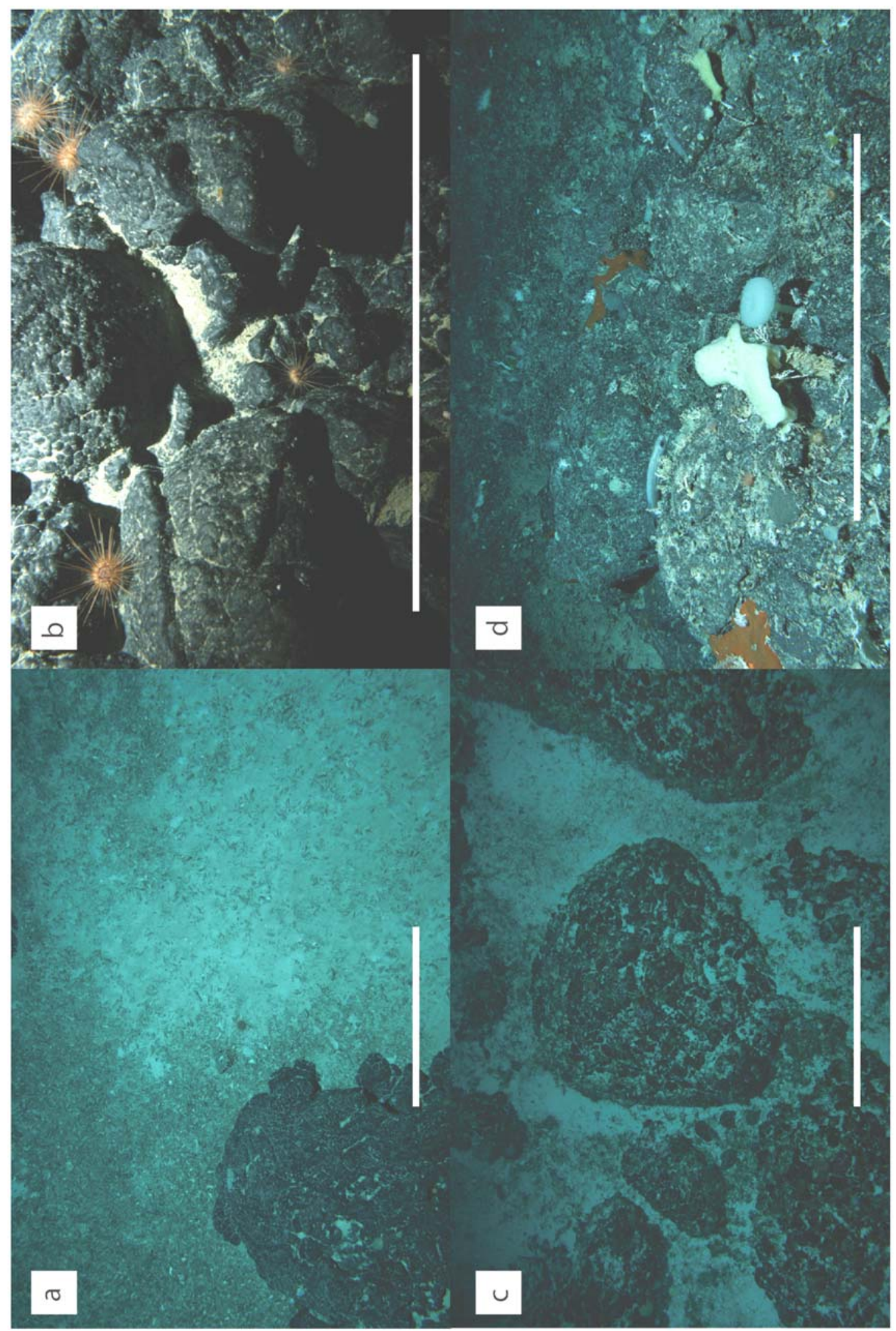

Figure A2.1. Examples of pillow lava flows from DTIS investigation of the seafloor. Scale bar is $1 \mathrm{~m}$. 


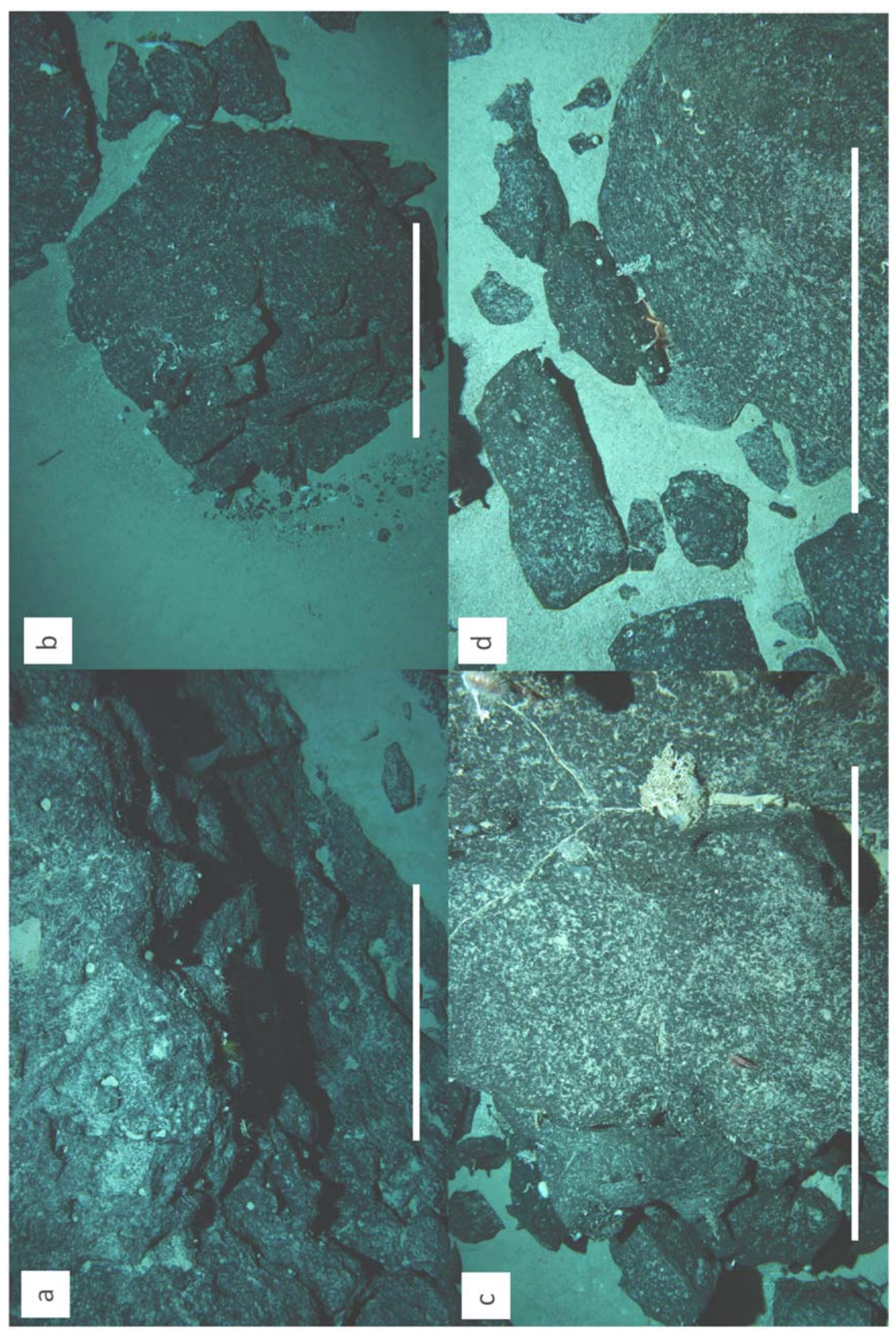

Figure A2.2. Examples of massive lava flows from DTIS investigation of the MRC. Scale bar is $1 \mathrm{~m}$. 


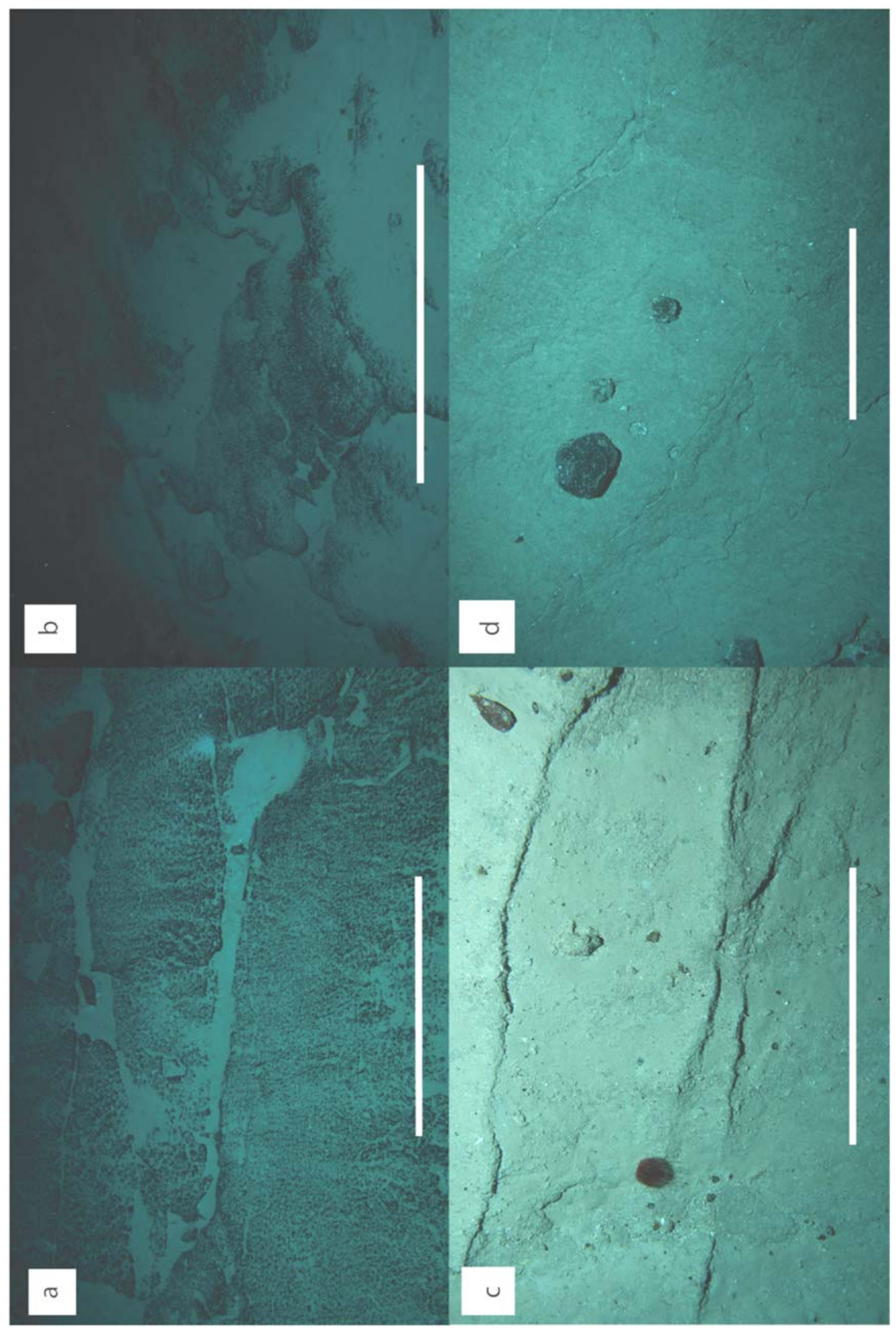

Figure A2.3. Examples of sheet lava flows from DTIS investigation of the MRC. Scale bar is $1 \mathrm{~m}$. 


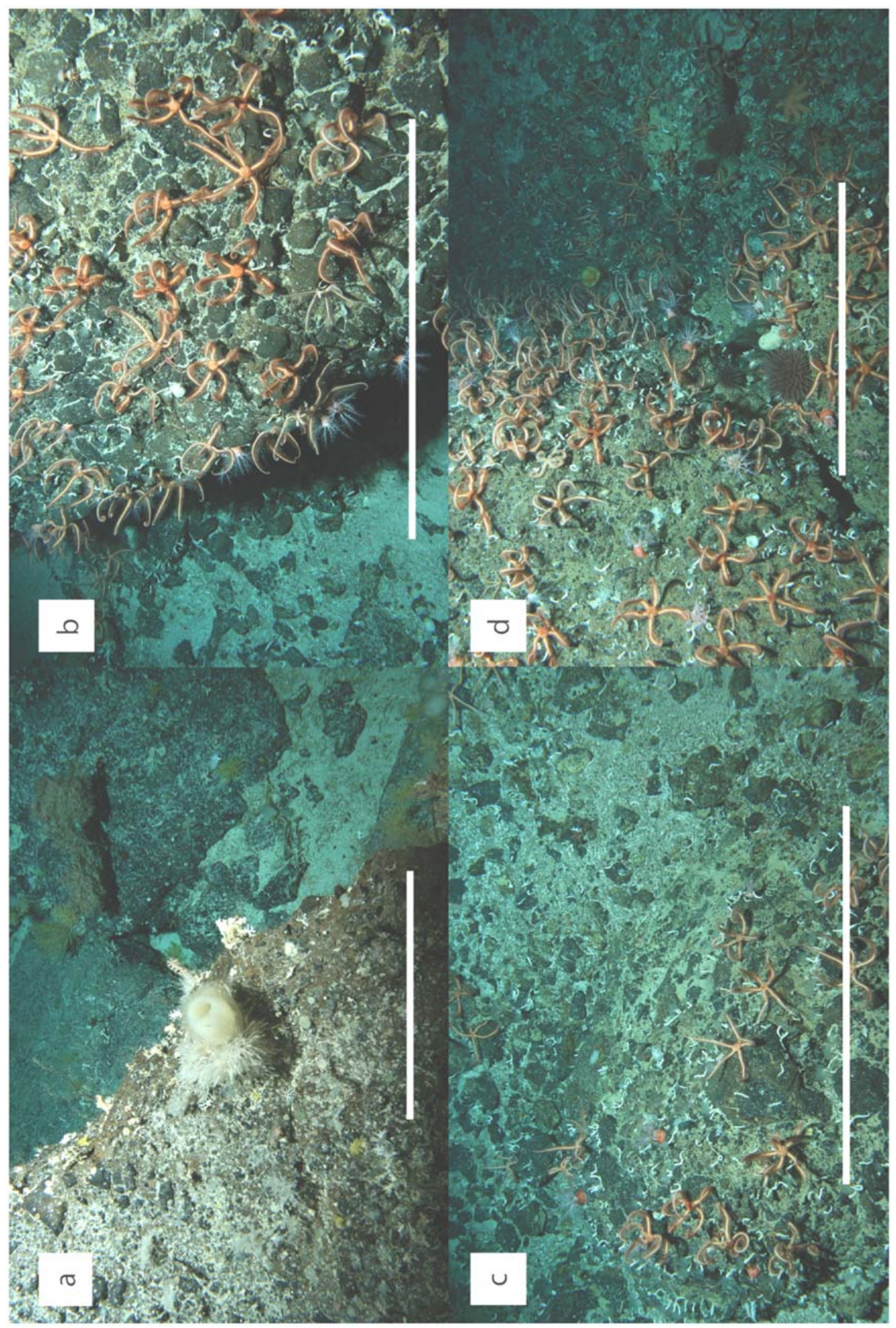

Figure A2.4. Examples of volcaniclastic breccias from DTIS investigation of the MRC. Scale bar is $1 \mathrm{~m}$. 


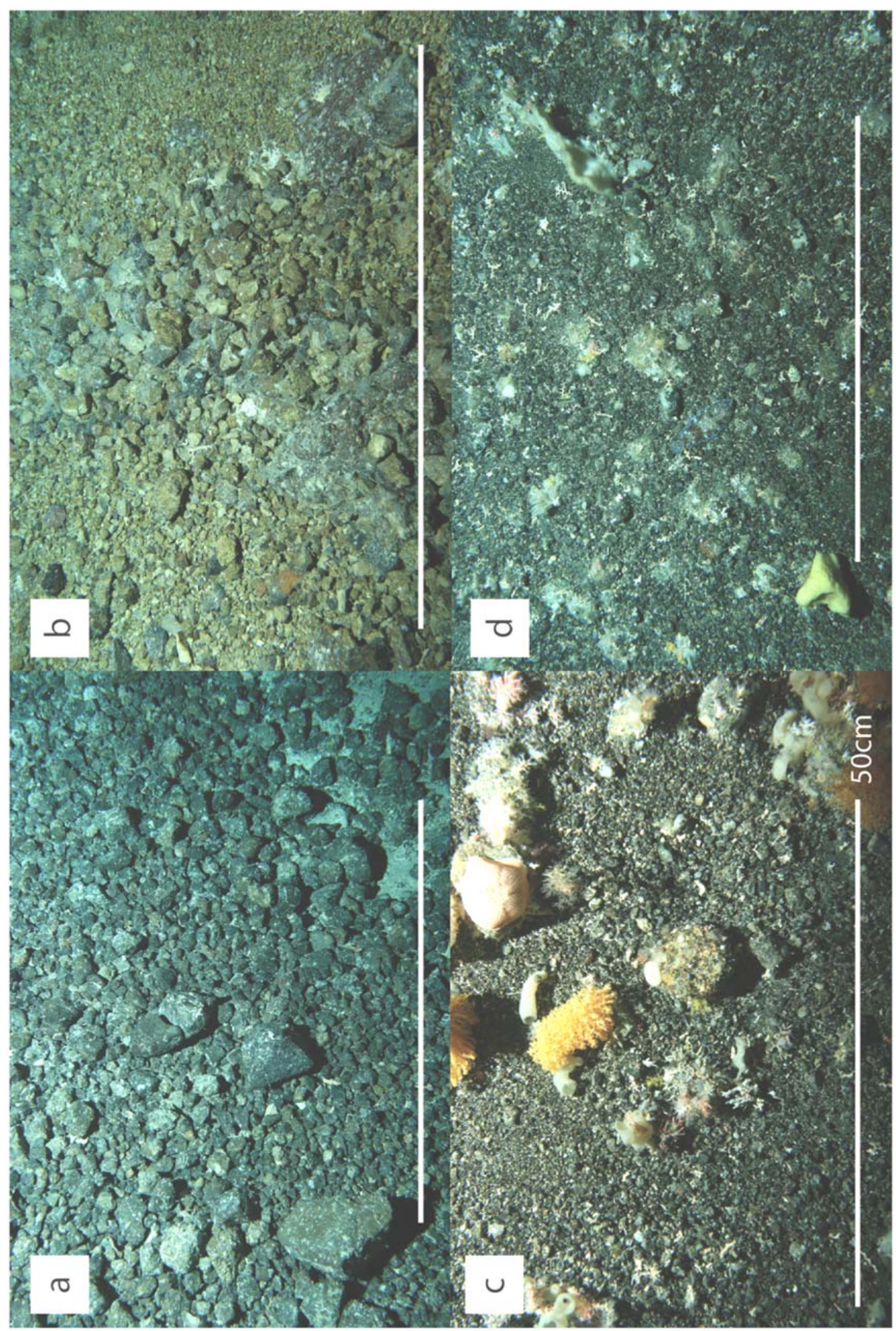

Figure A2.5. Examples of lava talus and clastic substrates from DTIS investigation of the MRC. Scale bar is $1 \mathrm{~m}$, except for $\mathrm{c}(50 \mathrm{~cm})$. 


\section{APPENDIX 3:}

\section{PETROGRAPHIC DECRIPTIONS}

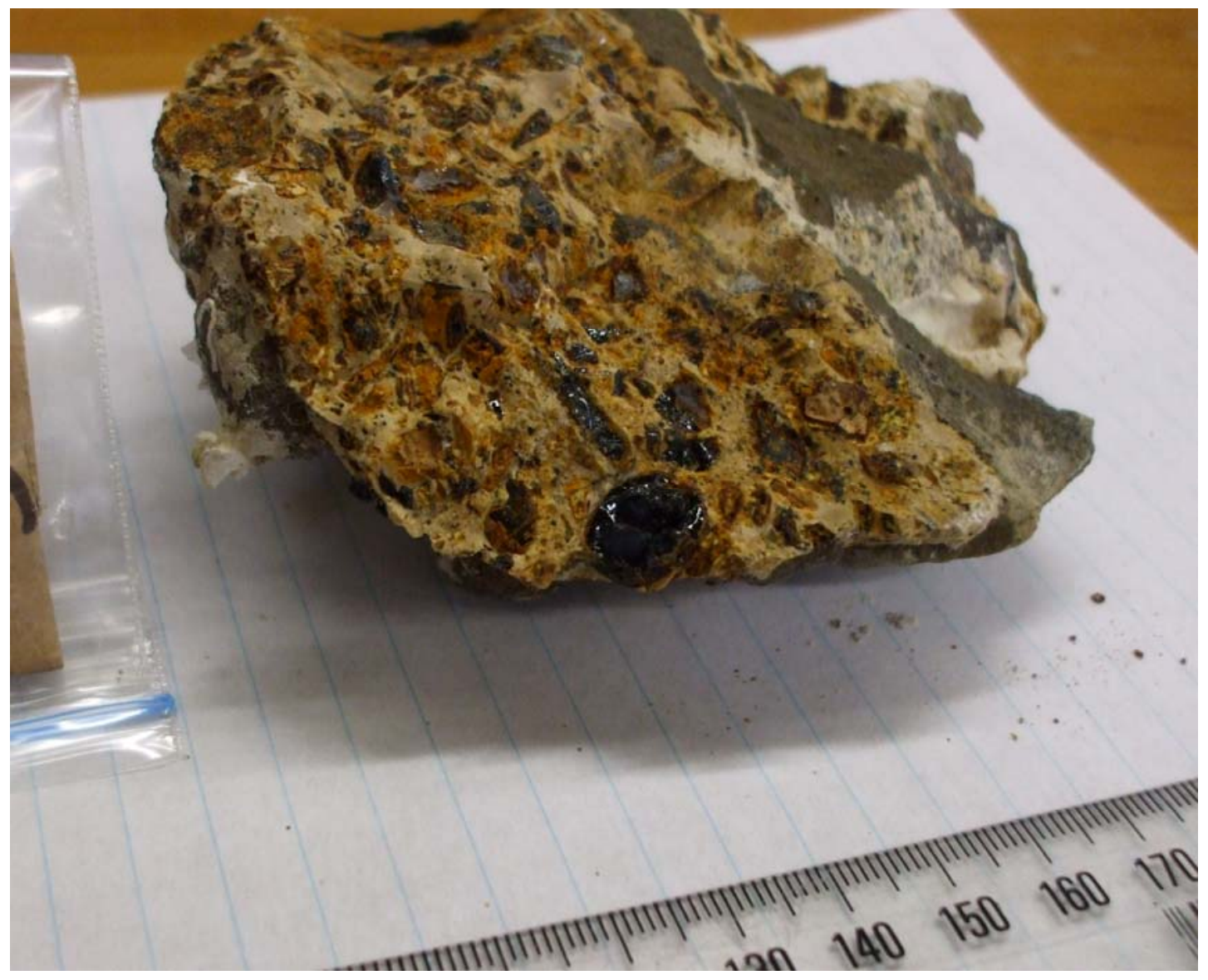

Plate 10. Photograph of a hyaloclastite breccia sample recovered from the Macquarie Ridge Complex seafloor. 


\section{A3.1. PETROGRAPHIC DESCRIPTIONS}

Figure A3.1 displays photographs and microphotographs (plane-polarised light) of whole rock samples from the Macquarie Ridge Complex used in this study. Table A3.1. provides an overview of sample petrography. Basic petrographic descriptions of whole rock samples are presented below:

B31 Basalt: Sparsely porphyritic and non-vesicular. Glass groundmass (85\%) is blackbrown. Plagioclase $(10 \%)$ occurs as elongate needles and sparse phenocrysts $(<1$ $\mathrm{mm}$ ) in the groundmass. Olivine and pyroxene present as small $(<0.5 \mathrm{~mm})$ phenocrysts (5\%).

B35 Basalt: Sparsely porphyritic and moderately vesicular. Groundmass is dominantly glass (80\%) with plagioclase microphenocrysts (5\%). Vesicles (15\%) are circular, often coalesce and some rims are lined with palagonite where the groundmass has been hydrothermally altered.

B36 Basalt: Sparsely porphyritic and non-vesicular. Groundmass comprised of fresh glass $(90 \%)$ and plagioclase microphenocrysts. Phenocrysts in groundmass are plagioclase (4\%) and pyroxene (1\%).

B38B Basalt: Sparsely porphyritic and sparsely vesicular. No thin section.

B48C Basalt: Aphyric and non-vesicular. Groundmass is comprised of devitrified glass (80\%) and plagioclase microphenocrysts (20\%).

B63 Basalt: Aphyric and non-vesicular. Tabular plagioclase crystals (50\%) are generally $0.5 \mathrm{~mm}$-long. All other phases altered beyond recognition or replaced by serpentinite.

B65 Basalt: Aphyric and moderately vesicular. Groundmass (85\%) comprised mainly of fresh glass and some palagonite near vesicle edges. Microphenocrysts of 
plagioclase occur in the groundmass (10\%). Vesicles $(5 \%)$ are round with diameters $<0.5 \mathrm{~mm}$.

B67 Basalt: Porphyritic and non-vesicular. Groundmass comprised of fresh glass (85\%) and sparse plagioclase microphenocrysts. Plagioclase phenocrysts (10\%) are < $5 \mathrm{~mm}$ and show substantial alteration.

B69B Basalt: Porphyritic and non-vesicular. Groundmass is comprised of fresh glass (60\%) and plagioclase microphenocrysts (30\%). Plagioclase phenocrysts (10\%) are < $2 \mathrm{~mm}$.

P77B Plutonic: Crystalline-granular. Substantially altered. Large plagioclase crystals (60\%) are generally significantly altered. Serpentine (10\%); plagioclase $(5 \%)$; opaque oxides (5\%).

B79 Basalt: Aphyric and non-vesicular. Very fine-grained, crystalline texture; mineral phases unable to be identified.

B82[1241]B Basalt: Sparsely porphyritic and non-vesicular. Groundmass is comprised of fresh glass (95\%) with sparse microphenocrysts. Phenocrysts are exclusively tabular plagioclase (5\%).

B82[1242]B Basalt: Sparsely porphyritic and non-vesicular. Groundmass comprises fresh glass (80\%) and microphenocrysts (15\%). Plagioclase phenocrysts (5\%) are tabular and $<0.5 \mathrm{~mm}$.

B84 Basalt: Aphyric and non-vesicular. Groundmass comprised of fresh glass (60\%). Needle-shaped plagioclase crystals (40\%).

D89 Diabase: Holocrystalline texture. Individual crystals $<4 \mathrm{~mm}$. Dominant minerals are plagioclase (60\%) and hornblende (40\%).

D91 Diabase: Holocrystalline texture. Extensively altered. Plagioclase is the dominant mineral phase, present as tabular crystals $(<0.5 \mathrm{~mm})$. Hornblende and pyroxene phases have been completely altered. 
P93 Gabbro: Crystalline-granular texture. Individual minerals are $<3 \mathrm{~mm}$ and are all substantially altered. Olivine (30\%) occurs as altered crystals or is replaced by muscovite and serpentine (30\%). Pyroxene (10\%), plagioclase (25\%) and oxides (5\%) are present throughout the sample.

P94 Plutonic: Crystalline-granular texture. Substantially altered. Plagioclase (60\%) present as large grains, which show alteration, and smaller tabular crystals. Serpentine (25\%), pyroxene (10\%), and oxides (5\%) also present.

B98B Basalt: Porphyritic and non-vesicular. Groundmass comprised of fresh glass $(80 \%)$ and plagioclase microphenocrysts (5\%). Plagioclase phenocrysts (15\%) are tabular, occur in clusters and are $<1 \mathrm{~mm}$.

B114 Basalt: Porphyritic and vesicular. Groundmass comprised of fresh glass (75\%). Mineral phases are pyroxene (10\%), which can display exsolution lamellae and zoning, olivine (5\%), and plagioclase (5\%). Vesicles (5\%) are partially to completely filled with calcite.

Table A3.1. Summary of petrographic types for MRC samples.

\begin{tabular}{|l|l|l|l|}
\hline Type & Texture & Description & $\#$ \\
\hline $\begin{array}{l}\text { Plagioclase-phyric } \\
\text { basalt }\end{array}$ & $\begin{array}{l}\text { Porphyritic; } \\
\text { phenocryst content: } \\
10 \pm 5 \%\end{array}$ & $\begin{array}{l}\text { Plagioclase } \pm \text { olivine, pyroxene } \\
\text { phenocrysts hosted in glass } \\
\text { groundmass. }\end{array}$ & 10 \\
\hline Aphyric basalt & $\begin{array}{l}\text { Non-porphyritic or } \\
\text { fine-grained } \\
\text { crystalline }\end{array}$ & $\begin{array}{l}\text { Plagioclase microphenocrysts, glass } \\
\text { groundmass. }\end{array}$ & 5 \\
\hline Pillow lava glass & $\begin{array}{l}\text { Non- to sparsely } \\
\text { porphyritic and } \\
\text { vesicular }\end{array}$ & $\begin{array}{l}\text { Quenched rinds of lava flow; fresh, } \\
\text { vitreous glass. }\end{array}$ & 5 \\
\hline $\begin{array}{l}\text { Volcaniclastic } \\
\text { breccia }\end{array}$ & $\begin{array}{l}\text { Non- to highly } \\
\text { porphyritic and } \\
\text { vesicular }\end{array}$ & $\begin{array}{l}\text { Angular glass and lava clasts } \\
\text { cemented by palagonite matrix. }\end{array}$ & 4 \\
\hline Plutonic & $\begin{array}{l}\text { Coarse-grained } \\
\text { crystalline }\end{array}$ & $\begin{array}{l}\text { Plagioclase, olivine, pyroxene } \\
\text { mineral assemblage. }\end{array}$ & 2 \\
\hline Diabase & Holocrystalline & $\begin{array}{l}\text { Plagioclase-hornblende mineral } \\
\text { assemblage. }\end{array}$ & 2 \\
\hline Gabbro & Crystalline-granular & Plagioclase, olivine, pyroxene. & 1 \\
\hline
\end{tabular}




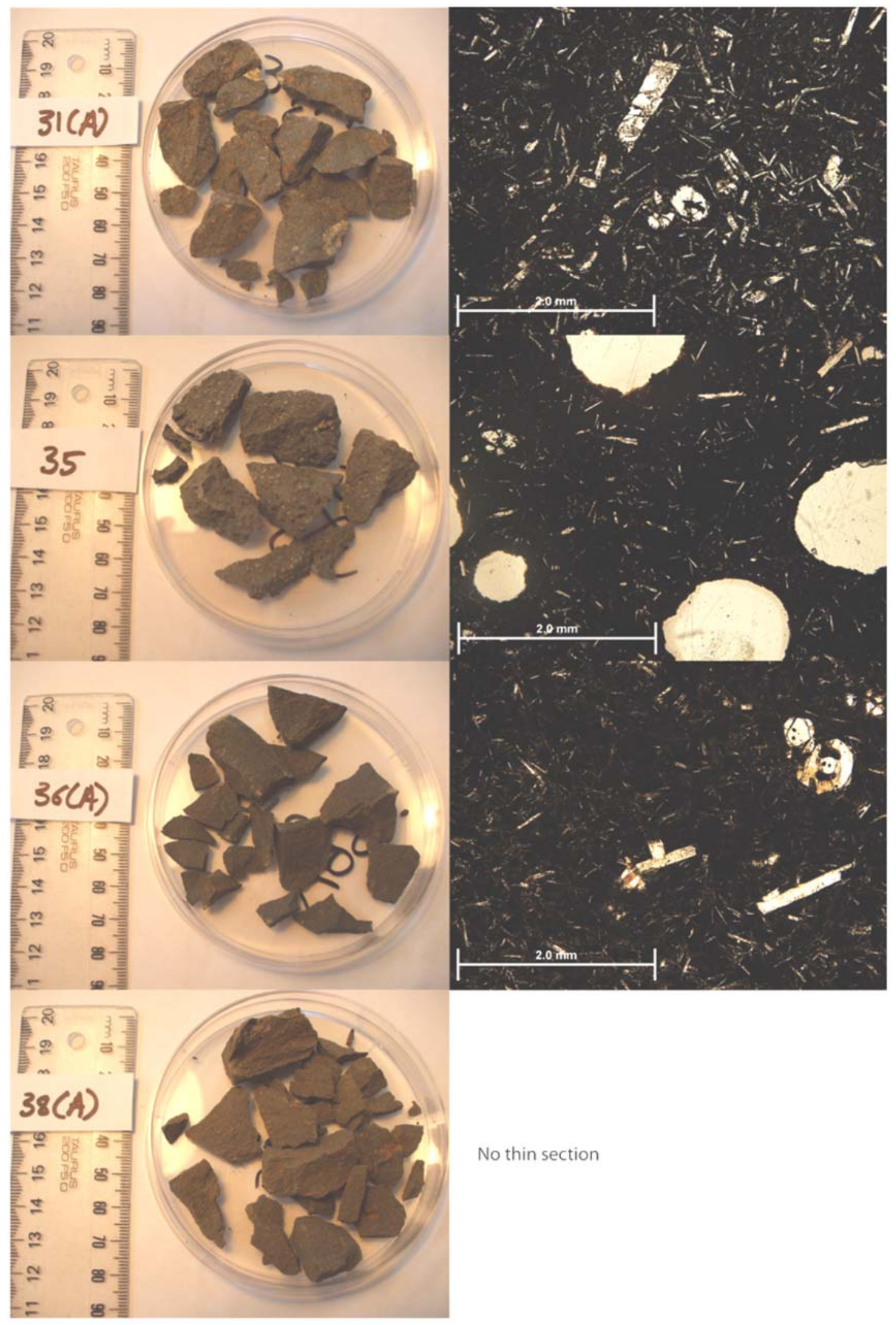

Figure A3.1. Photographs and microphotographs (plane-polarised light) of MRC dredge samples. 


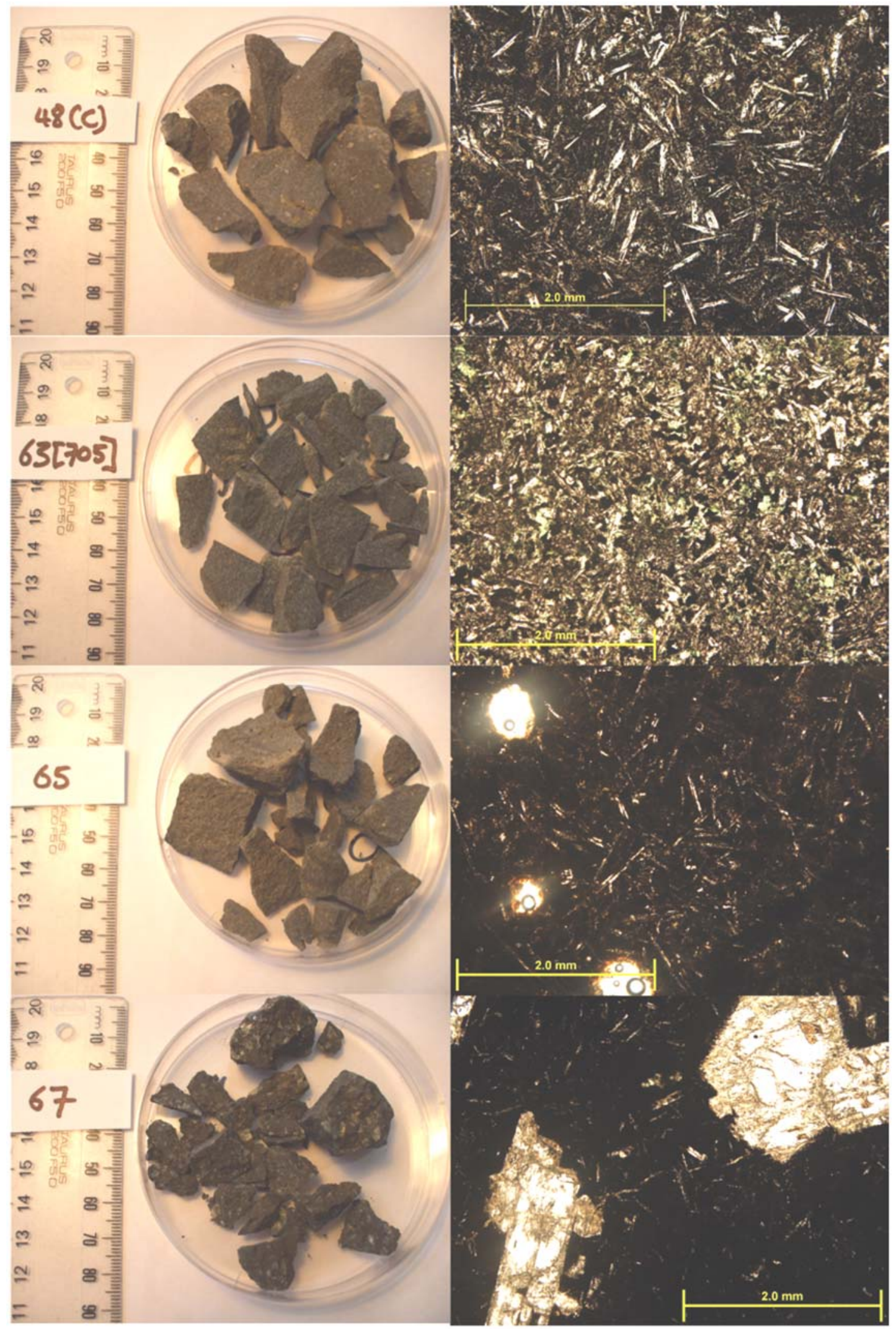

Figure A3.1. cont. Photographs and microphotographs (plane-polarised light) of MRC dredge samples. 


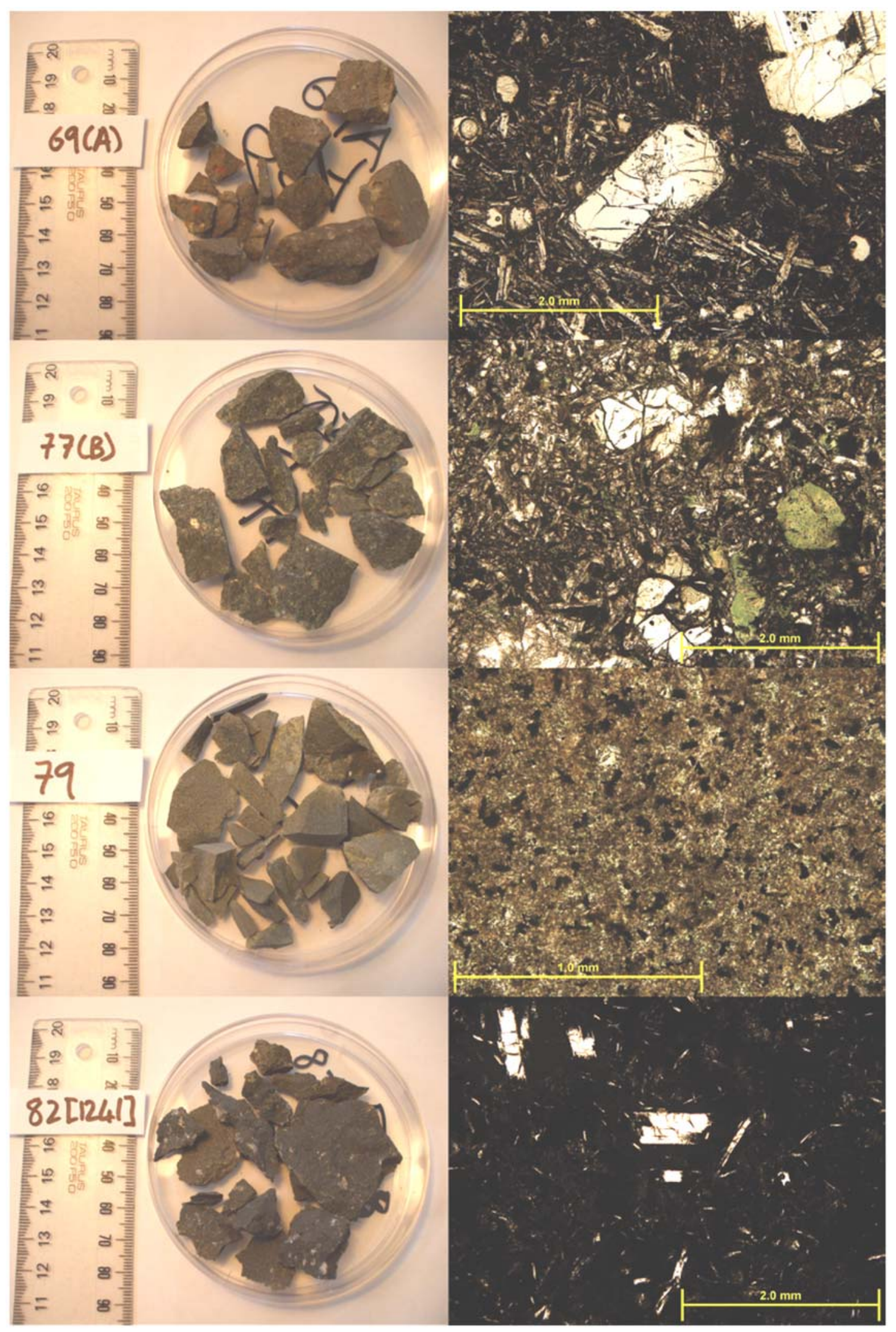

Figure A3.1. cont. Photographs and microphotographs (plane-polarised light) of MRC dredge samples. 


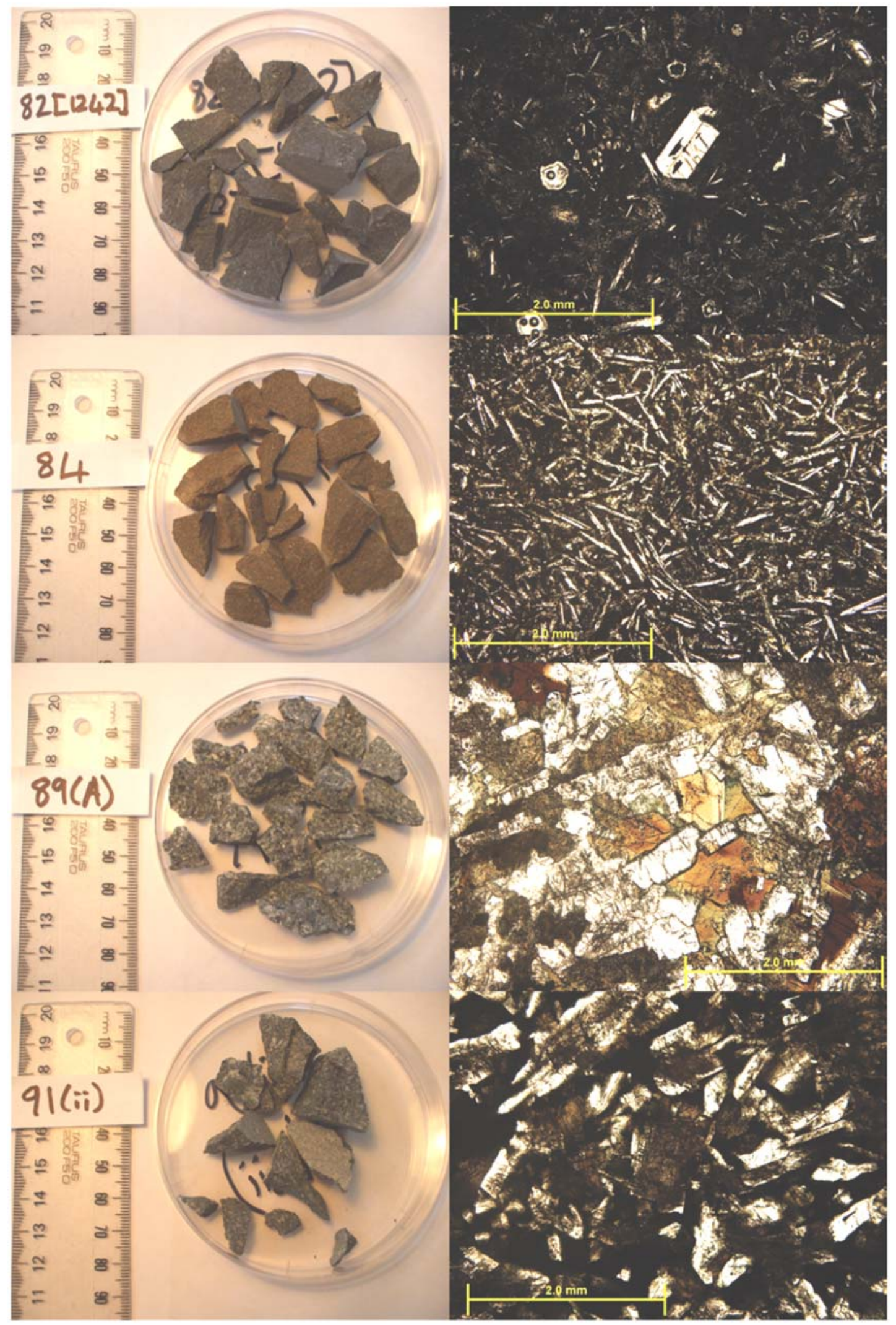

Figure A3.1. cont. Photographs and microphotographs (plane-polarised light) of MRC dredge samples. 


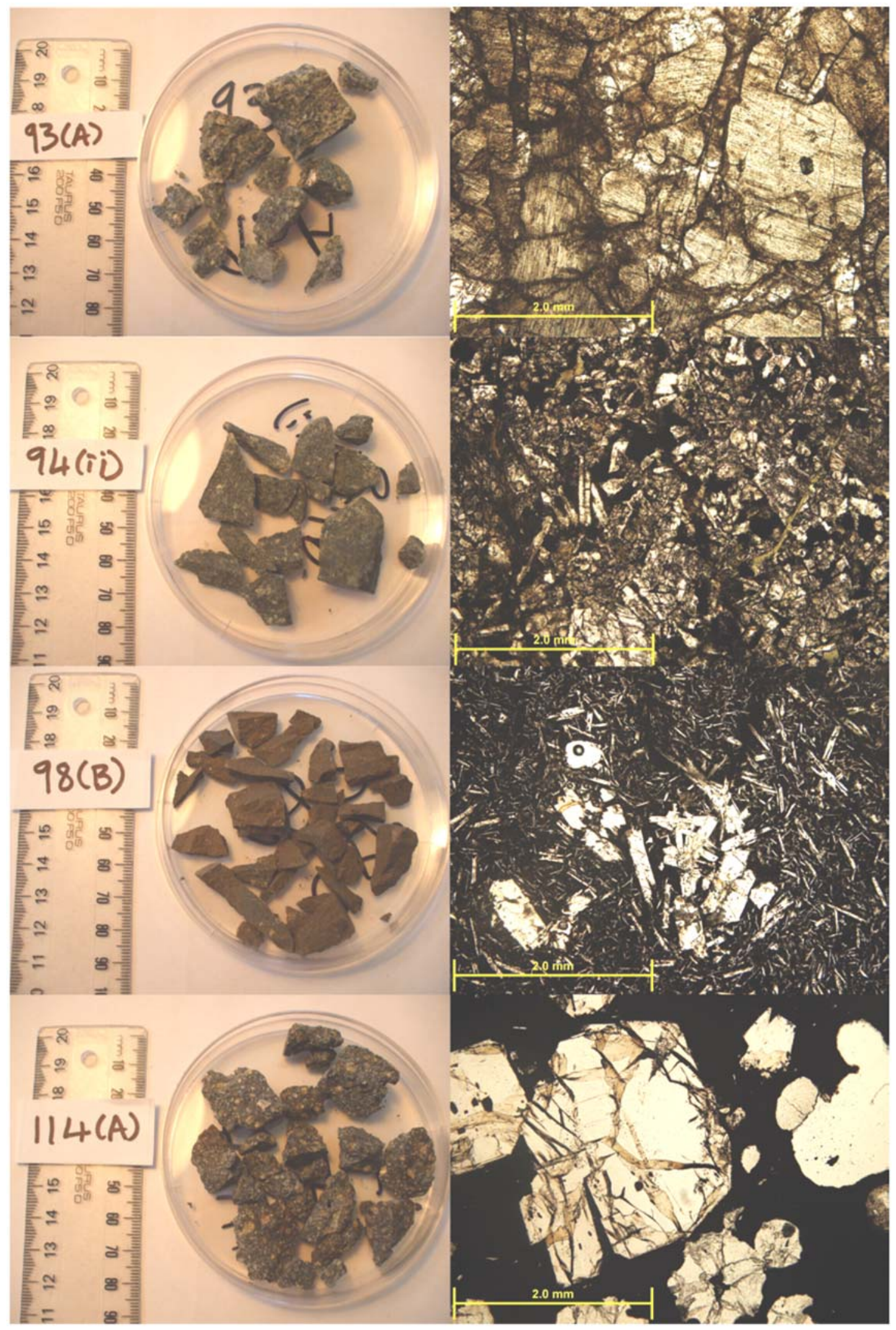

Figure A3.1. cont. Photographs and microphotographs (plane-polarised light) of MRC dredge samples. 